In cooperation with the U.S. Environmental Protection Agency

Changes in Groundwater Flow and Volatile Organic Compound Concentrations at the Fischer and Porter Superfund Site, Warminster Township, Bucks County, Pennsylvania, 1993-2009

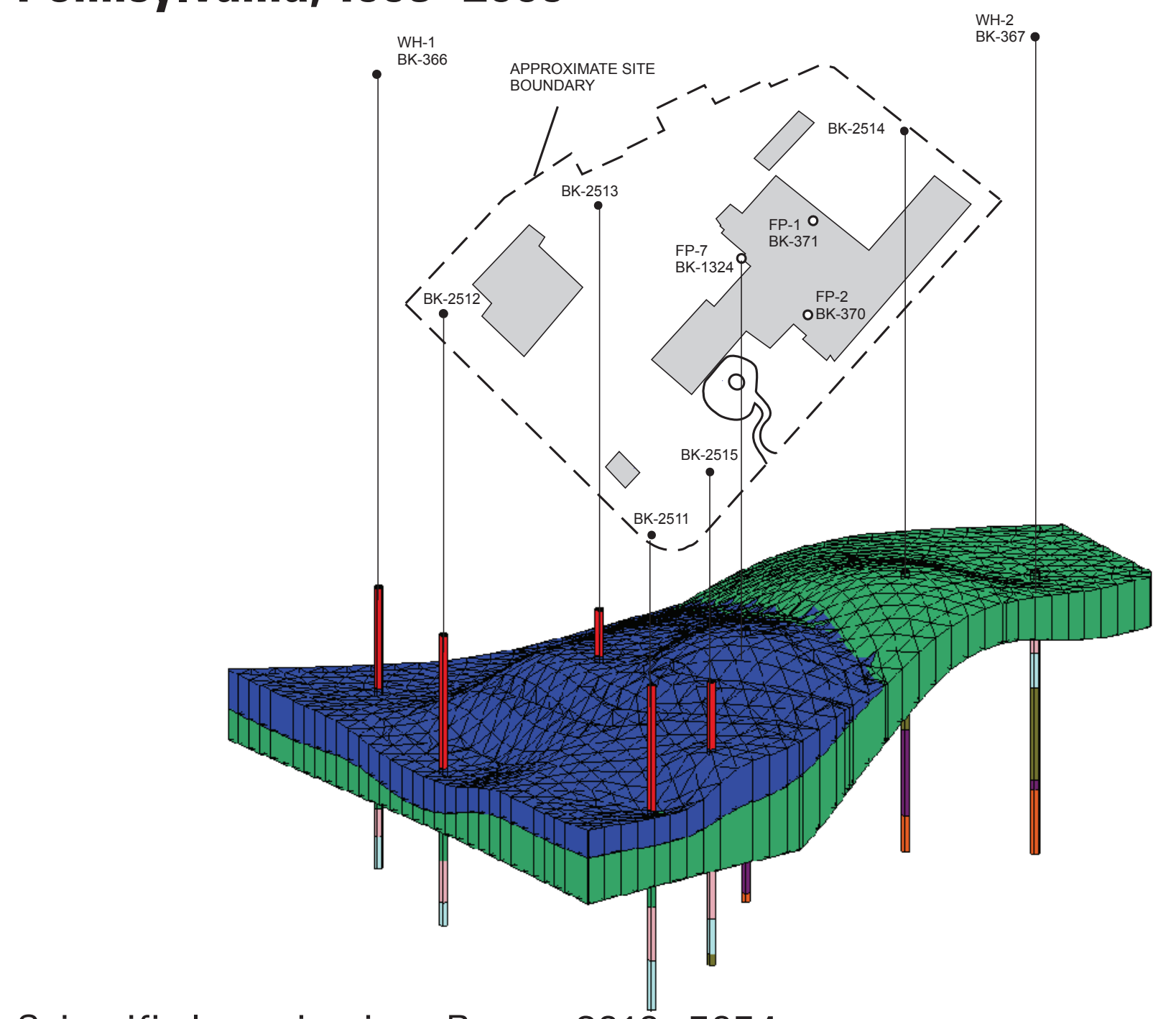

Scientific Investigations Report 2010-5054 
Cover. Location of stratigraphic units 2 and 3 at the Fischer and Porter Superfund Site, Warminster Township, Bucks County, Pennsylvania. 


\section{Changes in Groundwater Flow and Volatile Organic Compound Concentrations at the Fischer and Porter Superfund Site, Warminster Township, Bucks County, Pennsylvania, 1993-2009}

By Ronald A. Sloto

In cooperation with the U.S. Environmental Protection Agency

Scientific Investigations Report 2010-5054 


\section{U.S. Department of the Interior \\ KEN SALAZAR, Secretary \\ U.S. Geological Survey \\ Marcia K. McNutt, Director}

U.S. Geological Survey, Reston, Virginia: 2010

For more information on the USGS - the Federal source for science about the Earth, its natural and living resources, natural hazards, and the environment, visit http://www.usgs.gov or call 1-888-ASK-USGS

For an overview of USGS information products, including maps, imagery, and publications, visit http://www.usgs.gov/pubprod

To order this and other USGS information products, visit http://store.usgs.gov

Any use of trade, product, or firm names is for descriptive purposes only and does not imply endorsement by the U.S. Government.

Although this report is in the public domain, permission must be secured from the individual copyright owners to reproduce any copyrighted materials contained within this report.

Suggested citation:

Sloto, R.A., 2010, Changes in groundwater flow and volatile organic compound concentrations at the Fischer and Porter Superfund Site, Warminster Township, Bucks County, Pennsylvania, 1993-2009: U.S. Geological Survey Scientific Investigations Report 2010-5054, 115 p. 


\section{Contents}

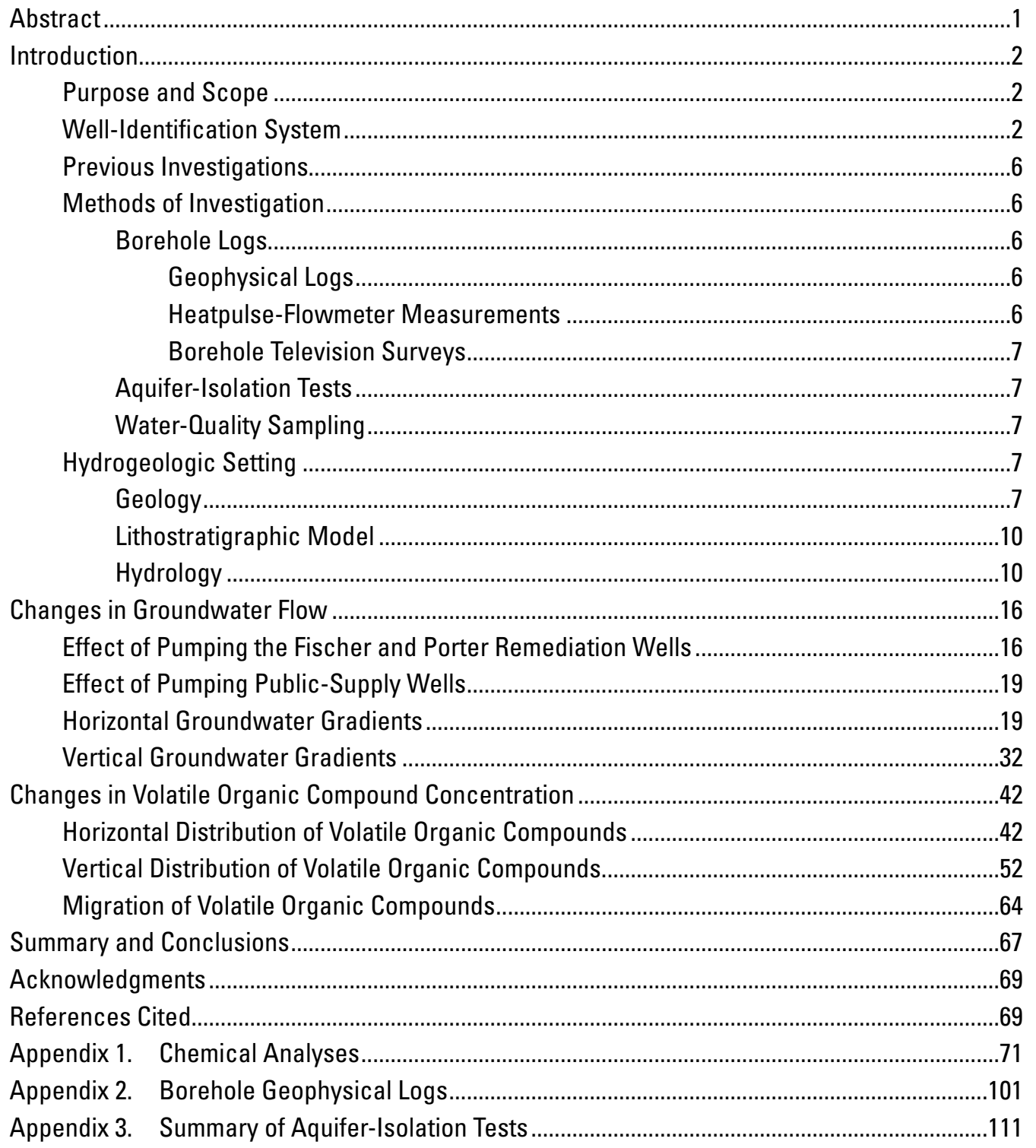




\section{Figures}

1. Map showing location of the Fischer and Porter Superfund Site, Warminster Township, Bucks County, Pennsylvania.

2. Map showing location of wells at the Fischer and Porter Superfund Site,

Warminster Township, Bucks County, Pennsylvania.

3. Generalized sketch of straddle-packer assembly and sampling pump in a borehole......8

4. Map showing location of geologic sections at the Fischer and Porter Superfund Site, Warminster Township, Bucks County, Pennsylvania.

5. Geologic section A-C at the Fischer and Porter Superfund Site, Warminster Township, Bucks County, Pennsylvania.

6. Geologic section B-C at the Fischer and Porter Superfund Site, Warminster Township, Bucks County, Pennsylvania.

7. Geologic section D-F at the Fischer and Porter Superfund Site, Warminster Township, Bucks County, Pennsylvania

8. Generalized lithostratigraphy, Fischer and Porter Superfund Site, Warminster Township, Bucks County, Pennsylvania

9. Map showing recovery of water levels in deep wells caused by the 1993-94 shutdowns of the remediation wells, Fischer and Porter Superfund Site, Warminster Township, Bucks County, Pennsylvania.

10. Map showing recovery of water levels in intermediate-depth wells caused by the 1993-94 shutdowns of the remediation wells, Fischer and Porter Superfund Site, Warminster Township, Bucks County, Pennsylvania.

11. Map showing change in water level in deep wells caused by the pumping of the Warminster Heights supply wells, Fischer and Porter Superfund Site, Warminster Township, Bucks County, Pennsylvania, 1993-94

12. Map showing change in water level in intermediate-depth wells caused by the pumping of the Warminster Heights supply wells, Fischer and Porter Superfund Site, Warminster Township, Bucks County, Pennsylvania.

13. Map showing potentiometric surface measured in wells screened in the shallow zone at the Fischer and Porter Superfund Site, Warminster Township, Bucks County, Pennsylvania, September 15, 2006

14. Map showing potentiometric surface measured in wells screened in the shallow zone at the Fischer and Porter Superfund Site, Warminster Township, Bucks County, Pennsylvania, January 16-20, 2007

15. Map showing potentiometric surface measured in wells screened in the shallow zone at the Fischer and Porter Superfund Site, Warminster Township, Bucks County, Pennsylvania, May 21-22, 2009

16. Map showing potentiometric surface measured in wells screened in the intermediate zone at the Fischer and Porter Superfund Site, Warminster Township, Bucks County, Pennsylvania, September 15, 2006

17. Map showing potentiometric surface measured in wells screened in the intermediate zone at the Fischer and Porter Superfund Site, Warminster Township, Bucks County, Pennsylvania, January 16-20, 2007.

18. Map showing potentiometric surface measured in wells screened in the intermediate zone at the Fischer and Porter Superfund Site, Warminster Township, Bucks County, Pennsylvania, May 21-22, 2009.

19. Map showing potentiometric surface measured in wells screened in the deep zone at the Fischer and Porter Superfund Site, Warminster Township, Bucks County, Pennsylvania, September 15, 2006. 
20. Map showing potentiometric surface measured in wells screened in the deep zone at the Fischer and Porter Superfund Site, Warminster Township, Bucks County, Pennsylvania, January 16-20, 2007.

21. Map showing potentiometric surface measured in wells screened in the deep zone at the Fischer and Porter Superfund Site, Warminster Township, Bucks County, Pennsylvania, May 21-22, 2009.

22. Cross section showing water-level altitude and direction of groundwater flow along section D-C, Fischer and Porter Superfund Site, Warminster Township, Bucks County, Pennsylvania, September 15, 2006

23. Cross section showing water-level altitude and direction of groundwater flow along section D-C, Fischer and Porter Superfund Site, Warminster Township, Bucks County, Pennsylvania, May 21-22, 2009.

24. Cross section showing water-level altitude and direction of groundwater flow along section D-C, Fischer and Porter Superfund Site, Warminster Township, Bucks County, Pennsylvania, December 13, 1993.

25. Cross section showing water-level altitude and direction of groundwater flow along section D-C, Fischer and Porter Superfund Site, Warminster Township, Bucks County, Pennsylvania, December 15, 1993.

26. Cross section showing water-level altitude and direction of groundwater flow along section E-C, Fischer and Porter Superfund Site, Warminster Township, Bucks County, Pennsylvania, September 15, 2006.

27. Cross section showing water-level altitude and direction of groundwater flow along section E-C, Fischer and Porter Superfund Site, Warminster Township, Bucks County, Pennsylvania, January 16-20, 2007

28. Cross section showing water-level altitude and direction of groundwater flow along section E-C, Fischer and Porter Superfund Site, Warminster Township, Bucks County, Pennsylvania, December 13, 1993

29. Cross section showing water-level altitude and direction of groundwater flow along section E-C, Fischer and Porter Superfund Site, Warminster Township, Bucks County, Pennsylvania, December 15, 1993

30. Cross section showing water-level altitude and direction of groundwater flow along section D-E, Fischer and Porter Superfund Site, Warminster Township, Bucks County, Pennsylvania, December 13, 1993

31. Cross section showing water-level altitude and direction of groundwater flow along section D-E, Fischer and Porter Superfund Site, Warminster Township, Bucks County, Pennsylvania, January 16-20, 2007

32. Diagram showing typical reaction pathway for the anaerobic degradation of tetrachloroethylene and trichoroethylene by reductive dehalogenation

33. Graph showing concentration of trichloroethylene in monthly water samples from wells BK-370 and BK-371 (Fischer and Porter 1 and 2), Fischer and Porter Superfund Site, Warminster Township, Bucks County, Pennsylvania, 1997-2008.

34. Graph showing concentration of tetrachloroethylene in monthly water samples from wells BK-370 and BK-371 (Fischer and Porter 1 and 2), Fischer and Porter Superfund Site, Warminster Township, Bucks County, Pennsylvania, 1997-2008 . .47

35. Graph showing concentration of trichloroethylene in monthly water samples from well BK-1324 (Fischer and Porter 7), Fischer and Porter Superfund Site, Warminster Township, Bucks County, Pennsylvania, 1997-2008

36. Graph showing concentration of tetrachloroethylene in monthly water samples from well BK-1324 (Fischer and Porter 7), Fischer and Porter Superfund Site, Warminster Township, Bucks County, Pennsylvania, 1997-2008 
37. Map showing concentration of trichloroethylene in water samples from wells completed in the shallow zone, Fischer and Porter Superfund Site, Warminster Township, Bucks County, Pennsylvania, 1996-2007

38. Map showing concentration of tetrachloroethylene in water samples from wells completed in the shallow zone, Fischer and Porter Superfund Site, Warminster Township, Bucks County, Pennsylvania, 1996-2007

39. Map showing concentration of cis-1,2-dichloroethylene and trans-1,2-dichloroethylene in water samples from wells completed in the shallow zone, Fischer and Porter Superfund Site, Warminster Township, Bucks County, Pennsylvania, 2007

40. Map showing concentration of trichloroethylene in water samples from on-site wells completed in the intermediate zone and off-site wells completed in the deep zone, Fischer and Porter Superfund Site, Warminster Township, Bucks County, Pennsylvania, 1996-2009.

41. Map showing concentration of tetrachloroethylene in water samples from on-site wells completed in the intermediate zone and off-site wells completed in the deep zone, Fischer and Porter Superfund Site, Warminster Township, Bucks County, Pennsylvnaia, 1996-2009.

42. Map showing concentration of cis-1,2-dichloroethylene and trans-1,2-dichloroethylene in water samples from on-site wells completed in the intermediate zone and off-site wells completed in the deep zone, Fischer and Porter Superfund Site, Warminster Township, Bucks County, Pennsylvania, 2007.........55

43. Map showing concentration of trichloroethylene in water samples from wells open to the deep zone, Fischer and Porter Superfund Site, Warminster Township, Bucks County, Pennsylvania, 1996-2009

44. Map showing concentration of tetrachloroethylene in water samples from wells open to the deep zone, Fischer and Porter Superfund Site, Warminster Township, Bucks County, Pennsylvania, 1996-2009

45. Map showing concentration of cis-1,2-dichloroethylene and trans-1,2-dichloroethylene in water samples from wells open to the deep zone, Fischer and Porter Superfund Site, Warminster Township, Bucks County, Pennsylvania, 2007

46. Map showing concentration of vinyl chloride measured in water samples from wells at the Fischer and Porter Superfund Site, Warminster Township, Bucks County, Pennsylvania, 2007

47. Cross section showing concentration of trichloroethylene in water samples from wells along section A-C, Fischer and Porter Superfund Site, Warminster Township, Bucks County, Pennsylvania, 1996-2007

48. Cross section showing concentration of tetrachloroethylene in water samples from wells along section A-C, Fischer and Porter Superfund Site, Warminster Township, Bucks County, Pennsylvania, 1996-2007

49. Cross section showing concentration of trichloroethylene in water samples from wells along section B-C, Fischer and Porter Superfund Site, Warminster Township, Bucks County, Pennsylvania, 1996-2007

50. Cross section showing concentration of tetrachloroethylene in water samples from wells along section B-C, Fischer and Porter Superfund Site, Warminster Township, Bucks County, Pennsylvania, 1996-2007

51. Map showing maximum concentration of trichloroethylene in groundwater samples, Fischer and Porter Superfund Site, Warminster Township, Bucks County, Pennsylvania, 1979-80.

52. Diagram showing location of stratigraphic units 2 and 3 at the Fischer and Porter Superfund Site, Warminster Township, Bucks County, Pennsylvania. 


\section{Tables}

1. Record of wells at the Fischer and Porter Superfund Site, Warminster Township, Bucks County, Pennsylvania.

2. Volatile organic compounds analyzed in groundwater samples, Fischer and Porter Superfund Site, Warminster Township, Bucks County, Pennsylvania, 2007-09...

3. Changes in water level caused by pumping of the Warminster Heights supply wells and the shutdown of the Fischer and Porter remediation wells, Fischer and Porter Superfund Site, Warminster Township, Bucks County, Pennsylvania

4. Water levels measured at the Fischer and Porter Superfund Site, Warminster Township, Bucks County, Pennsylvania, 2006-09 .

5. Selected volatile organic compounds analyzed in groundwater, Fischer and Porter Superfund Site, Warminster Township, Bucks County, Pennsylvania, 2007-09. 


\section{Conversion Factors and Datums}

Inch/Pound to SI

\begin{tabular}{|c|c|c|}
\hline Multiply & By & To obtain \\
\hline \multicolumn{3}{|c|}{ Length } \\
\hline inch (in.) & 2.54 & centimeter $(\mathrm{cm})$ \\
\hline inch (in.) & 25.4 & millimeter $(\mathrm{mm})$ \\
\hline foot $(\mathrm{ft})$ & 0.3048 & meter $(\mathrm{m})$ \\
\hline mile (mi) & 1.609 & kilometer $(\mathrm{km})$ \\
\hline \multicolumn{3}{|c|}{ Area } \\
\hline acre & 4,047 & square meter $\left(\mathrm{m}^{2}\right)$ \\
\hline acre & 0.4047 & hectare (ha) \\
\hline \multicolumn{3}{|c|}{ Volume } \\
\hline gallon (gal) & 3.785 & liter $(\mathrm{L})$ \\
\hline gallon (gal) & 0.003785 & cubic meter $\left(\mathrm{m}^{3}\right)$ \\
\hline \multicolumn{3}{|c|}{ Flow rate } \\
\hline gallon per minute (gal/min) & 0.06309 & liter per second $(\mathrm{L} / \mathrm{s})$ \\
\hline \multicolumn{3}{|c|}{ Specific capacity } \\
\hline $\begin{array}{l}\text { gallon per minute per foot } \\
[(\mathrm{gal} / \mathrm{min}) / \mathrm{ft})]\end{array}$ & 0.2070 & liter per second per meter $[(\mathrm{L} / \mathrm{s}) / \mathrm{m}]$ \\
\hline \multicolumn{3}{|c|}{ Hydraulic conductivity } \\
\hline foot per day (ft/d) & 0.3048 & meter per day $(\mathrm{m} / \mathrm{d})$ \\
\hline \multicolumn{3}{|c|}{ Hydraulic gradient } \\
\hline foot per mile (ft/mi) & 0.1894 & meter per kilometer $(\mathrm{m} / \mathrm{km})$ \\
\hline
\end{tabular}

Temperature in degrees Celsius $\left({ }^{\circ} \mathrm{C}\right)$ may be converted to degrees Fahrenheit $\left({ }^{\circ} \mathrm{F}\right)$ as follows:

${ }^{\circ} \mathrm{F}=\left(1.8 \times^{\circ} \mathrm{C}\right)+32$

Vertical coordinate information is referenced to the North American Vertical Datum of 1988 (NAVD 88).

Horizontal coordinate information is referenced to the North American Datum of 1983 (NAD 83).

Altitude, as used in this report, refers to distance above the vertical datum.

Specific conductance is given in microsiemens per centimeter at 25 degrees Celsius $(\mu \mathrm{S} / \mathrm{cm}$ at $\left.25^{\circ} \mathrm{C}\right)$.

Concentrations of chemical constituents in water are given either in milligrams per liter $(\mathrm{mg} / \mathrm{L})$, micrograms per liter $(\mu \mathrm{g} / \mathrm{L})$, or micrograms per kilogram $(\mu \mathrm{g} / \mathrm{kg})$. 


\title{
Changes in Groundwater Flow and Volatile Organic Compound Concentrations at the Fischer and Porter Superfund Site, Warminster Township, Bucks County, Pennsylvania, 1993-2009
}

\author{
By Ronald A. Sloto
}

\section{Abstract}

The 38-acre Fischer and Porter Company Superfund Site is in Warminster Township, Bucks County, Pa. Historically, as part of the manufacturing process, trichloroethylene (TCE) degreasers were used for parts cleaning. In 1979, the Bucks County Health Department detected TCE and other volatile organic compounds (VOCs) in water from the Fischer and Porter on-site supply wells and nearby public-supply wells. The Fischer and Porter Site was designated as a Superfund Site and placed on the National Priorities List in September 1983. A 1984 Record of Decision for the site required the Fischer and Porter Company to pump and treat groundwater contaminated by VOCs from three on-site wells at a combined rate of 75 gallons per minute to contain groundwater contamination on the property. Additionally, the Record of Decision recognized the need for treatment of the water from two nearby privately owned supply wells operated by the Warminster Heights Home Ownership Association. In 2004, the Warminster Heights Home Ownership Association sold its water distribution system, and both wells were taken out of service. The report describes changes in groundwater levels and contaminant concentrations and migration caused by the shutdown of the Warminster Heights supply wells and presents a delineation of the off-site groundwater-contamination plume. The U.S. Geological Survey (USGS) conducted this study (2006-09) in cooperation with the U.S. Environmental Protection Agency (USEPA).

The Fischer and Porter Site and surrounding area are underlain by sedimentary rocks of the Stockton Formation of Late Triassic age. The rocks are chiefly interbedded arkosic sandstone and siltstone. The Stockton aquifer system is comprised of a series of gently dipping lithologic units with different hydraulic properties. A three-dimensional lithostratigraphic model was developed for the site on the basis of rock cores and borehole geophysical logs. The model was simplified by combining individual lithologic units into generalized units representing upward fining sedimentary cycles capped by a siltstone bed. These cycles were labeled units 1 through 8 and are called stratigraphic units in this report. Groundwater in the unweathered zone mainly moves through a network of interconnecting secondary openings - bedding-plane fractures and joints. Groundwater generally is unconfined in the shallower part of the aquifer and confined or semiconfined in the deeper part of the aquifer.

The migration of VOCs from the Fischer and Porter Site source area is influenced by geologic and hydrologic controls. The hydrologic controls have changed with time. Stratigraphic units 2 and 3 crop out beneath the former Fischer and Porter plant. VOCs originating at the plant source area entered these stratigraphic units and moved downdip to the northwest. When the wells at and in the vicinity of the site were initially sampled in 1979-80, three public-supply wells (BK-366, BK-367, and MG-946) and three industrial-supply wells (BK-368, BK-370, and BK-371) were pumping. Groundwater contaminated with VOCs flowed downdip and then northeast along strike toward well BK-366, downdip toward well BK-368, and downdip and then west along strike toward well MG-946. The long axis of the TCE plume is oriented about N. $18^{\circ} \mathrm{W}$. in the direction of dip. In 1979-80, the leading edge of the plume was about 3,500 feet wide. With the cessation of pumping of the supply wells in 2004, the size of the plume has decreased. In 2007-09, the plume was approximately 2,000 feet long and 2,000 feet wide at the leading edge.

On the western side of the site, TCE and tetrachloroethylene (PCE) appear to be moving downdip though stratigraphic unit 3. The downdip extent of TCE and PCE migration extended approximately 550 feet off-site to the northwest and 750 feet off-site to the north. TCE concentrations in water samples from wells at the western site boundary increased from 1996 to 2007. On the northern side of the site, TCE and PCE appeared to be moving downward and laterally though stratigraphic units 2,3 , and 4.

Groundwater-flow directions shifted to the northwest in the intermediate and deep zones after cessation of pumping of well BK-366 in 2004. The shutdown of the Warminster 
Heights wells had little effect on the direction of groundwater flow in the shallow zone.

In 2007, TCE concentrations measured in water samples from the three remediation wells by the USGS ranged from less than 340 to $3,000 \mu \mathrm{g} / \mathrm{L}$, and PCE concentrations ranged from less than 8.4 to $51 \mu \mathrm{g} / \mathrm{L}$. TCE concentrations in water samples from the source-area remediation wells have decreased with time but remain highly variable. From 2001 to 2008, the TCE and PCE concentrations in water samples from wells BK-370 and BK-371 showed a linear decreasing trend. TCE and PCE concentrations in water samples from well BK-1324 showed an exponentially decreasing trend.

In 2007, TCE concentrations measured in water samples from shallow wells ranged from less than 0.1 to $14,000 \mu \mathrm{g} / \mathrm{L}$, and PCE concentrations ranged from less than 0.1 to $340 \mu \mathrm{g} / \mathrm{L}$. The TCE and PCE plumes followed the hydraulic gradient in the shallow zone. In 2007, TCE concentrations measured in water samples from on-site intermediate-depth monitor wells ranged from less than 0.1 to $500 \mu \mathrm{g} / \mathrm{L}$, and PCE concentrations ranged from 1.3 to $28 \mu \mathrm{g} / \mathrm{L}$. The TCE and PCE plumes followed the hydraulic gradient in the intermediate zone and extended off-site to the north and northwest of the source area. Concentrations of TCE in water samples north and west of the source area increased from 1996 to 2007.

In 2007, the TCE concentrations measured in water samples from on-site monitor wells in the deep zone ranged from 1.1 to $86 \mu \mathrm{g} / \mathrm{L}$, and PCE concentrations ranged from less than 0.1 to $8.4 \mu \mathrm{g} / \mathrm{L}$. The TCE and PCE plumes generally followed the hydraulic gradient in the deep zone and extended off-site to the northwest of the source area. In general, concentrations of TCE in water samples from monitor wells outside the source area increased between 1996 and 2005 and decreased between 2005 and 2007; concentrations were less in 2007 than in 1996.

\section{Introduction}

The Fischer and Porter Company Superfund Site is northeast of the intersection of County Line and Jacksonville Roads in Warminster Township, Bucks County, Pa. (figs. 1 and 2). County Line Road is the boundary between Bucks and Montgomery Counties. The site occupies approximately 38 acres. The main manufacturing facility was constructed in 1940-41. Historically, as part of the manufacturing process, three trichloroethylene (TCE) degreasers were operated for parts cleaning in the main building (CH2M Hill, Inc., 1998, p. 1-2).

In 1979, the Bucks County Health Department detected TCE and other volatile organic compounds (VOCs) in water from the Fischer and Porter on-site supply wells and from nearby public-supply wells operated by the Warminster Heights Home Ownership Association and Hatboro Borough. The Fischer and Porter Site was designated as a Superfund Site and placed on the National Priorities List in September 1983. A 1984 Record of Decision (ROD) for the site required the Fischer and Porter Company to pump and treat groundwater contaminated by VOCs from three on-site wells (wells FP-1, FP-2, and FP-7 on fig. 2) at a combined rate of $75 \mathrm{gal} / \mathrm{min}$ to contain groundwater contamination on the property. Additionally, the ROD recognized the need for treatment of the water from two nearby privately owned supply wells operated by the Warminster Heights Home Ownership Association (wells WH-1 and WH-2 on fig. 2).

A subsequent ROD issued in 1998 confirmed the contaminant plume was being contained by the combined action of the three Fischer and Porter remediation wells and supply well WH-1, which influenced the direction of groundwater flow and contaminant migration from the site. The 1998 ROD also recognized that there was no requirement for the continued operation of well WH-1 and, therefore, required re-evaluation of the remedy if that well ceased to operate. In 2004, the Warminster Heights Home Ownership Association sold its water distribution system to the Warminster Municipal Authority, and both Warminster Heights wells were taken out of service. Cessation of pumping of these wells caused changes to the groundwater-flow system in the vicinity of the Fischer and Porter Site. The U.S. Environmental Protection Agency (USEPA) requested the assistance of the U.S. Geological Survey (USGS) at the Fischer and Porter Site for the completion of the 5-year review initiated in 2004 at the site.

\section{Purpose and Scope}

This report presents water-level, water-quality, geophysical, geologic, and aquifer-test data collected for the Fischer and Porter Site and vicinity from 2004 to 2009 . Water levels were measured in 20 on-site and 7 off-site wells. Samples for laboratory analysis were collected from 22 on-site and 8 offsite wells. As part of this study, five additional off-site monitor wells (wells BK-3042, BK-3043, BK-3044, BK-3045, and BK-3046 on fig. 2) were drilled for this study. Geologic logs, borehole geophysical logs (caliper, natural-gamma, singlepoint-resistance, fluid-resistivity, and fluid-temperature), and heatpulse-flowmeter measurements were collected and aquifer-isolation tests were conducted in these wells. The report describes changes in groundwater levels and VOC contaminant concentrations and migration caused by the shutdown of the Warminster Heights supply wells in 2004. It also presents a delineation of the off-site groundwater-contamination plume.

\section{Well-Identification System}

A cross-reference between site and USGS well-identification numbers is given in table 1 . Locations of the wells are shown on figure 2 . 


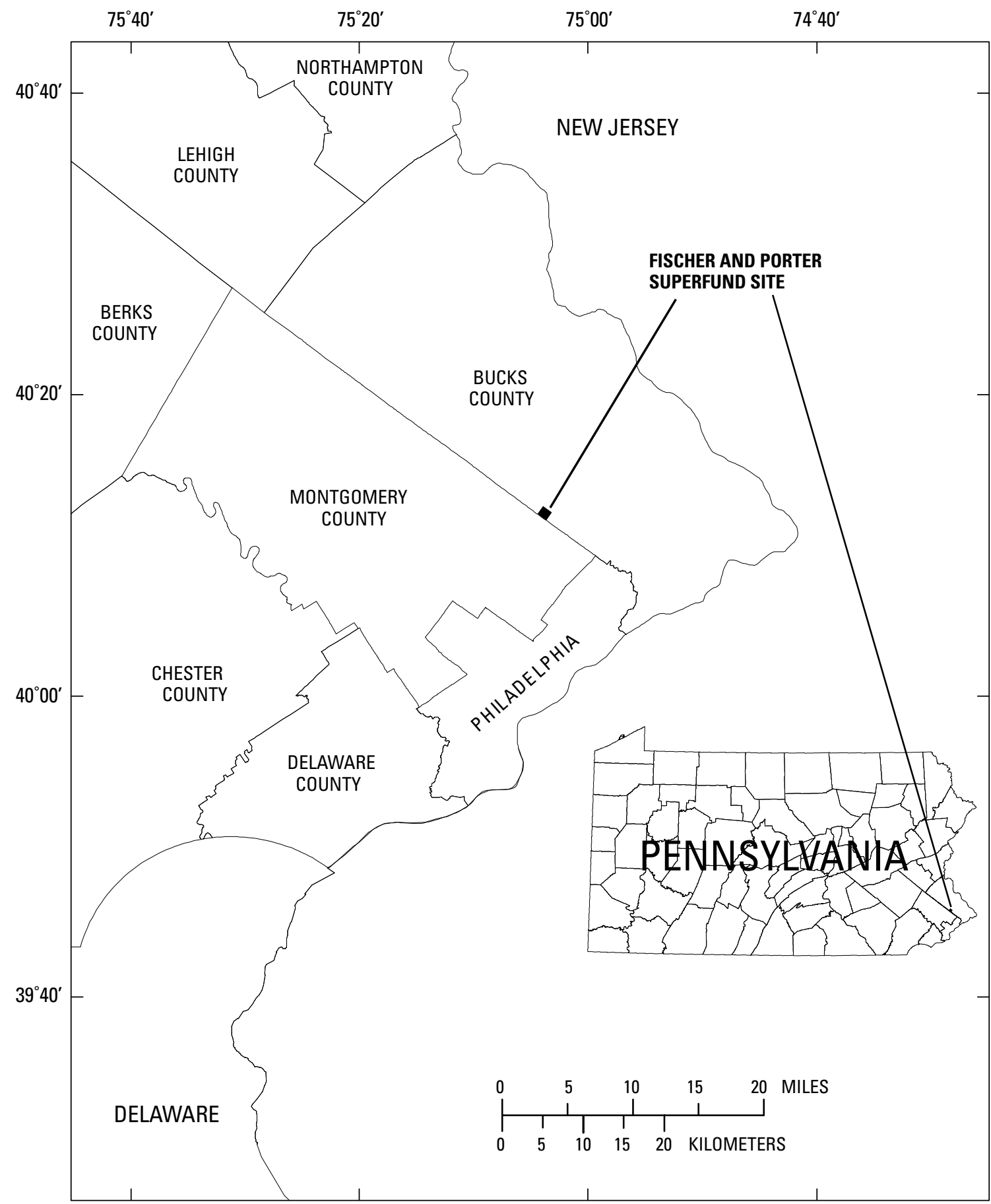

Base from U.S. Geological Survey digital data,1972,

1:2,000,000 Albers Equal-Area Conic Projection.

Standard parallels $29^{\circ} 30^{\prime} \mathrm{N}$, central meridian $75^{\circ} 00^{\prime} \mathrm{W}$.

Figure 1. Location of the Fischer and Porter Superfund Site, Warminster Township, Bucks County, Pennsylvania. 


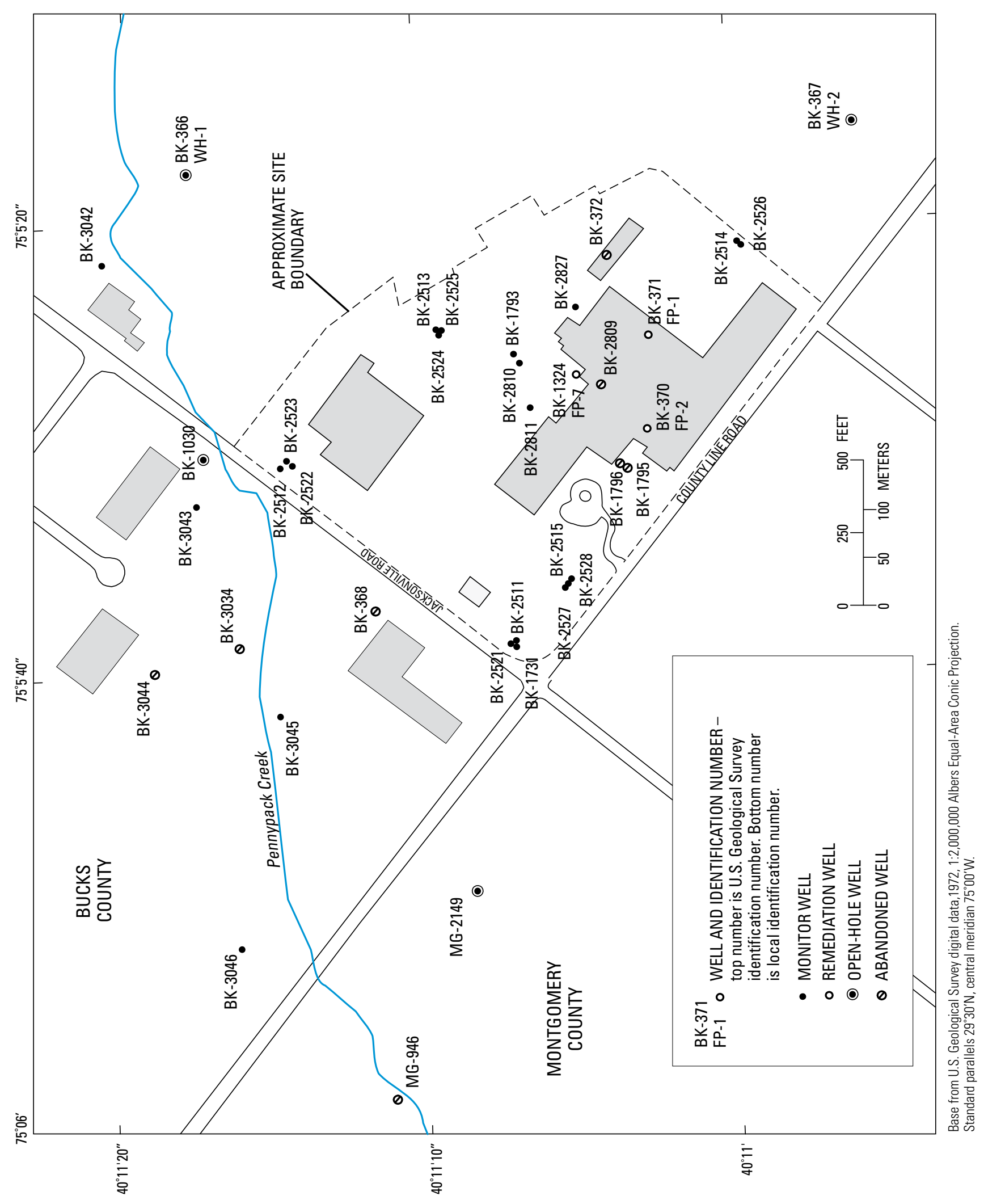

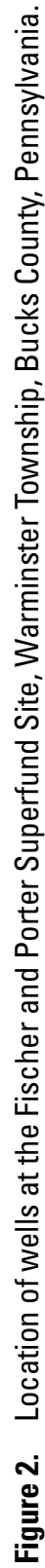


Table 1. Record of wells at the Fischer and Porter Superfund Site, Warminster Township, Bucks County, Pennsylvania.

[USGS, U.S. Geological Survey; USEPA, U.S. Environmental Protection Agency; --, no data; bls, below land surface; OH, open hole; S, screened; D, abandoned]

\begin{tabular}{|c|c|c|c|c|c|}
\hline $\begin{array}{c}\text { USGS } \\
\text { identification } \\
\text { number }\end{array}$ & Owner or owner identification number & $\begin{array}{l}\text { Depth drilled } \\
\text { (feet) }\end{array}$ & $\begin{array}{c}\text { Casing } \\
\text { diameter } \\
\text { (inches) }\end{array}$ & $\begin{array}{c}\text { Open or screened } \\
\text { interval } \\
\text { (feet bls) }\end{array}$ & Construction \\
\hline BK-366 & Warminster Heights WH-1 & 300 & 8 & $40-300$ & $\mathrm{OH}$ \\
\hline BK-367 & Warminster Heights WH-2 & 300 & 8 & $56-300$ & $\mathrm{OH}$ \\
\hline BK-368 & La Rosa 2 & 600 & 6 & -- & $\mathrm{D}$ \\
\hline BK-370 & Fischer and Porter FP-2 & 190 & 6 & $15-190$ & $\mathrm{OH}$ \\
\hline BK-371 & Fischer and Porter FP-1 & 474 & 8 & -- & $\mathrm{OH}$ \\
\hline BK-372 & Fischer and Porter FP-3 & 601 & 8 & -- & $\mathrm{D}$ \\
\hline BK-1030 & Warminster Municipal Authority & -- & 6 & -- & $\mathrm{OH}$ \\
\hline BK-1324 & Fischer and Porter FP-7 & 300 & 6 & $21.4-300$ & $\mathrm{OH}$ \\
\hline BK-1731 & USEPA & 300 & 6 & $47-65$ & $\mathrm{OH}$ \\
\hline BK-1793 & Fischer and Porter FP-5 & 40 & 6 & $23.4-40$ & $\mathrm{OH}$ \\
\hline BK-1795 & Fischer and Porter FP-8 & 54 & 6 & $23-31$ & $\mathrm{D}$ \\
\hline BK-1796 & Fischer and Porter FP-12 & 146 & 6 & $78-146$ & D \\
\hline BK-2511 & USEPA & 352 & 4 & $300-325$ & $\mathrm{~S}$ \\
\hline BK-2512 & USEPA & 303 & 4 & $237-257$ & $\mathrm{~S}$ \\
\hline BK-2513 & USEPA & 301 & 4 & $255-275$ & S \\
\hline BK-2514 & USEPA & 292 & 8 & $217-252$ & S \\
\hline BK-2515 & USEPA & 310 & 4 & $285-305$ & S \\
\hline BK-2521 & USEPA & 229 & 4 & $237-257$ & S \\
\hline BK-2522 & USEPA & 159 & 4 & $132-157$ & S \\
\hline BK-2523 & USEPA & 53 & 4 & $23.5-43.5$ & S \\
\hline BK-2524 & USEPA & 158 & 4 & $115-135$ & S \\
\hline BK-2525 & USEPA & 80 & 4 & $31-51$ & S \\
\hline BK-2526 & USEPA & 79 & 4 & $50-70$ & S \\
\hline BK-2527 & USEPA & 201 & 4 & $157-187$ & $\mathrm{~S}$ \\
\hline BK-2528 & USEPA & 53.5 & 4 & $25-45$ & S \\
\hline BK-2809 & USEPA PH-3 & 120 & 4 & $18-120$ & D \\
\hline BK-2810 & USEPA PH-1 & 120 & 4 & $20-120$ & $\mathrm{OH}$ \\
\hline BK-2811 & USEPA PH-2 & 120 & 4 & $10-120$ & $\mathrm{OH}$ \\
\hline BK-2827 & USEPA PH-4 & 120 & 4 & $20-120$ & $\mathrm{OH}$ \\
\hline BK-3034 & -- & 300 & 8 & -- & D \\
\hline BK-3042 & USEPA & 285 & 2 & $220-260$ & S \\
\hline BK-3043 & USEPA & 335 & 2 & $275-310$ & S \\
\hline BK-3044 & USEPA & 362 & 10 & $20-362$ & D \\
\hline BK-3045 & USEPA & 303 & 2 & $227-247$ & $\mathrm{~S}$ \\
\hline BK-3046 & USEPA & 355 & 2 & $280-310$ & S \\
\hline MG-946 & Hatboro Authority H-16 & 300 & 10 & $42-300$ & $\mathrm{D}$ \\
\hline MG-2149 & Delaware Valley Concrete Company & -- & -- & -- & $\mathrm{OH}$ \\
\hline
\end{tabular}




\section{Previous Investigations}

The geology and hydrology of the Stockton Formation in southeastern Pennsylvania was described by Rima and others (1962). In the Hatboro area, it was described by Sloto and others (1996). Sloto and Davis (1983) described the effect of urbanization on the water resources of Warminster Township. Groundwater studies at the Fischer and Porter Site include those by SMC Martin, Inc. (1980), BCM, Inc. (1986), Sloto and others (1995), CH2M Hill, Inc. (1998), and TetraTech EM, Inc. (2005).

\section{Methods of Investigation}

Data collected for this study include geophysical, geological, water-level, and water-quality data. A description of how the data were collected is presented below.

\section{Borehole Logs}

For this study, borehole logs were collected in wells BK-3042, BK-3043, BK-3044, BK-3045, and BK-3046. Borehole logs include geophysical logs, heatpulse-flowmeter measurements, and borehole television surveys.

\section{Geophysical Logs}

For this study, caliper, natural-gamma, single-pointresistance, fluid-resistivity, and fluid-temperature borehole geophysical logs and heatpulse-flowmeter measurements were collected in five boreholes (BK-3042, BK-3043, BK-3044, BK-3045, and BK-3046). Borehole geophysical logs are presented in appendix 2. The logs were used to locate water-producing fractures, determine the rate and direction of vertical movement of water in the borehole, and determine intervals to be isolated by straddle packers for the aquifer-isolation tests.

Caliper logs provide a continuous record of average borehole diameter, which is related to fractures, lithology, and drilling technique. Caliper logs were used to identify fractures and possible water-producing openings. Correlation of caliper logs with fluid-resistivity and fluid-temperature logs was used to identify water-producing and water-receiving fractures or fracture zones. The term fracture used in association with the caliper-log interpretations might identify a change in borehole diameter that may not necessarily indicate a bedding-plane separation, lithologic contact, or water-producing or waterreceiving zone but may simply indicate an enlargement of the borehole.

Natural-gamma logs, also called gamma-ray logs, record the natural-gamma radiation emitted from rocks penetrated by the borehole. Uranium-238, thorium-232, and the progeny of their decay series and potassium- 40 are the most common emitters of natural-gamma radiation. These radioactive elements are concentrated in clays by adsorption, precipitation, and ion exchange. Fine-grained sediments, such as mudstone or siltstone, usually emit more gamma radiation than sandstone. Geophysical logging with a gamma probe can be conducted in the water-filled, dry, cased, or uncased parts of the borehole (Keys, 1990). However, casing reduces the gamma response. The gamma logs were used to help correlate lithologic units between boreholes.

Single-point-resistance logs record the electrical resistance between the borehole and an electrical ground at land surface. In general, resistance increases with grain size and decreases with borehole diameter, density of water-producing fractures, and increasing dissolved-solids concentration of borehole water (Keys, 1990). A water-filled borehole is required for single-point-resistance logs, and they are run only for the saturated part of the formation below the casing. Single-point-resistance logs were used to help correlate lithology between boreholes and to help identify water-producing fractures or fracture zones.

Fluid-resistivity logs measure the electrical resistance of the water in the borehole. Resistivity is the reciprocal of fluid conductivity, and fluid-resistivity logs reflect changes in the dissolved-solids concentration of the borehole water. Fluidresistivity logs were used to identify water-producing and water-receiving zones and to determine intervals of vertical borehole flow. Water-producing and water-receiving zones usually are identified by sharp changes in resistivity. Intervals of vertical borehole flow usually are identified by a lowresistivity gradient between a water-producing and a waterreceiving zone.

Fluid-temperature logs provide a continuous record of the vertical water-temperature variation in the borehole. Fluidtemperature logs were used to identify water-producing and water-receiving zones and to determine intervals of vertical borehole flow. Water-producing and water-receiving zones usually are identified by sharp changes in temperature, and intervals of vertical borehole flow are identified by little or no temperature gradient.

\section{Heatpulse-Flowmeter Measurements}

The direction and rate of borehole-fluid movement were measured with a high-resolution heatpulse flowmeter. Heatpulse-flowmeter measurements are presented in appendix 2 . The heatpulse flowmeter operates by diverting nearly all flow to the center of the tool where a heating grid slightly heats a thin zone of water. If vertical borehole flow is occurring, the water moves up or down the borehole to one of two sensitive thermistors (heat sensors). When a peak temperature is recorded by one of the thermistors, a measurement of direction and rate is calculated by the computer collecting the logging data. The range of flow measurement for this tool is about 0.01 to $1.5 \mathrm{gal} / \mathrm{min}$ in an 8 -in. diameter borehole. Heatpulse-flowmeter measurements may be affected by poor seal integrity between the borehole and the flowmeter. If the seal between the borehole and the heatpulse flowmeter is not complete, some water can bypass the flowmeter, resulting in flow measurements that are less than the actual rate. The 
quantity of water bypassing the tool is a function of borehole size and shape and degree of fracturing. Although the heatpulse flowmeter is a calibrated tool, the data primarily are used as a relative indicator of water-producing zones.

\section{Borehole Television Surveys}

Borehole television surveys were conducted by lowering a waterproof video camera down the borehole and recording the image on video tape. The borehole television surveys were used to characterize water-producing fractures and to locate smooth sections of borehole to set the packers.

\section{Aquifer-Isolation Tests}

Because most groundwater flow and contaminant movement at the Fischer and Porter Site occurs in distinct waterbearing fractures rather than through primary openings in the rock, it is important to define the hydraulic and chemical characteristics of important, discrete water-bearing fractures. This characterization only can be performed by isolating each water-bearing fracture with straddle packers so that its properties can be separated from the other water-bearing fractures in the borehole. These tests are called aquifer-isolation tests and commonly are referred to as packer tests. Aquifer-isolation tests were conducted in five boreholes (BK-3042, BK-3043, BK-3044, BK-3045, and BK-3046). Data from aquifer-isolation tests are summarized in appendix 3.

The straddle-packer assembly (fig. 3) consisted of two inflatable rubber bladders (packers) about $4 \mathrm{ft}$ long set on 2-in.-diameter lift pipe with a pump set between the packers. The distance from the center of the upper packer to the center of the lower packer varied.

Several aquifer-isolation tests were conducted in each borehole. Intervals selected for aquifer-isolation tests were based on the borehole geophysical logs and borehole television surveys. The packer assembly was lowered to the selected depth in the borehole, and the packers were inflated against the borehole wall, isolating the selected interval. Exact depths to set packers were based on the location of smooth sections of borehole wall determined from the caliper logs and borehole television surveys. For the test of most intervals, both packers were inflated ( $B$ on fig. 3 ). For the test of the lowermost isolated interval in most boreholes, only the upper packer was inflated ( $A$ on fig. 3). For the test of the uppermost isolated interval in all boreholes, only the lower packer was inflated ( $C$ on fig. 3). Inflation of both packers created three intervals - an upper interval above the upper packer, the isolated interval between the packers, and a lower interval below the lower packer. Pressure in the packers was monitored continuously so that the packers always remained at maximum inflation. After the packers were inflated, water levels in each interval usually were allowed to stabilize before pumping began. Water levels were recorded above, below, and in the isolated interval.
During aquifer-isolation tests, measurements of water levels were made in each interval by calibrated pressure transducers and recorded by a digital data logger. Water levels initially were determined by electric measuring tapes; these water levels were used to calibrate the transducers. The transducers were set in measurement tubes open to the monitored intervals. The accuracy of the transducer in the isolated interval was $\pm 0.06 \mathrm{ft}$. The accuracy of the transducers used in the intervals above and below the isolated interval was $\pm 0.03 \mathrm{ft}$. Calibrated, in-line flowmeters were used to measure discharge. The water was treated by a granulated active carbon filtration system before discharge.

The specific capacity of each isolated interval was calculated by dividing the pumping rate by the drawdown. The specific capacity for each isolated interval is given in appendix 3 . Water samples were collected prior to the end of each test by opening a sampling port in the discharge line before the flowmeter and the activated carbon treatment system. This caused the pumping rate to increase and the water level to decline. The specific capacity was determined using the drawdown just prior to sampling. Specific capacity is affected by the pumping rate and the length of pumping. In general, a higher pumping rate and (or) a longer pumping duration will result in a lower specific capacity.

\section{Water-Quality Sampling}

Water samples were collected for laboratory analysis for VOCs (table 2). Water-quality data are presented in appendix 1. Most wells were purged a minimum of three volumes before collecting the sample. Approximately two volumes were purged from wells WH-1 and WH-2. Well BK-3034 was flowing when sampled. Well MG-2149 was pumping when sampled. Sampled wells were purged until field determinations (dissolved oxygen, $\mathrm{pH}$, specific conductance, and temperature) stabilized. Purge water was treated by a granulated active carbon filtration system before discharge. Samples were collected in 40-milliliter septum bottles, placed on ice, and shipped overnight to the USGS laboratory in Arvada, Colo.

\section{Hydrogeologic Setting}

The Fischer and Porter Site is in the Gettysburg-Newark Lowlands Section of the Piedmont Physiographic Province. The site and surrounding area are underlain by sedimentary rocks of the Stockton Formation of Late Triassic age.

\section{Geology}

The Stockton Formation is the basal unit of the Newark Supergroup rocks in the Triassic-Jurassic Newark Basin. The Stockton Formation is subdivided into three units called the lower arkose, middle arkose, and upper shale members by Rima and others (1962). The rocks that underlie the Fischer and Porter Site belong to the middle arkose member. The 

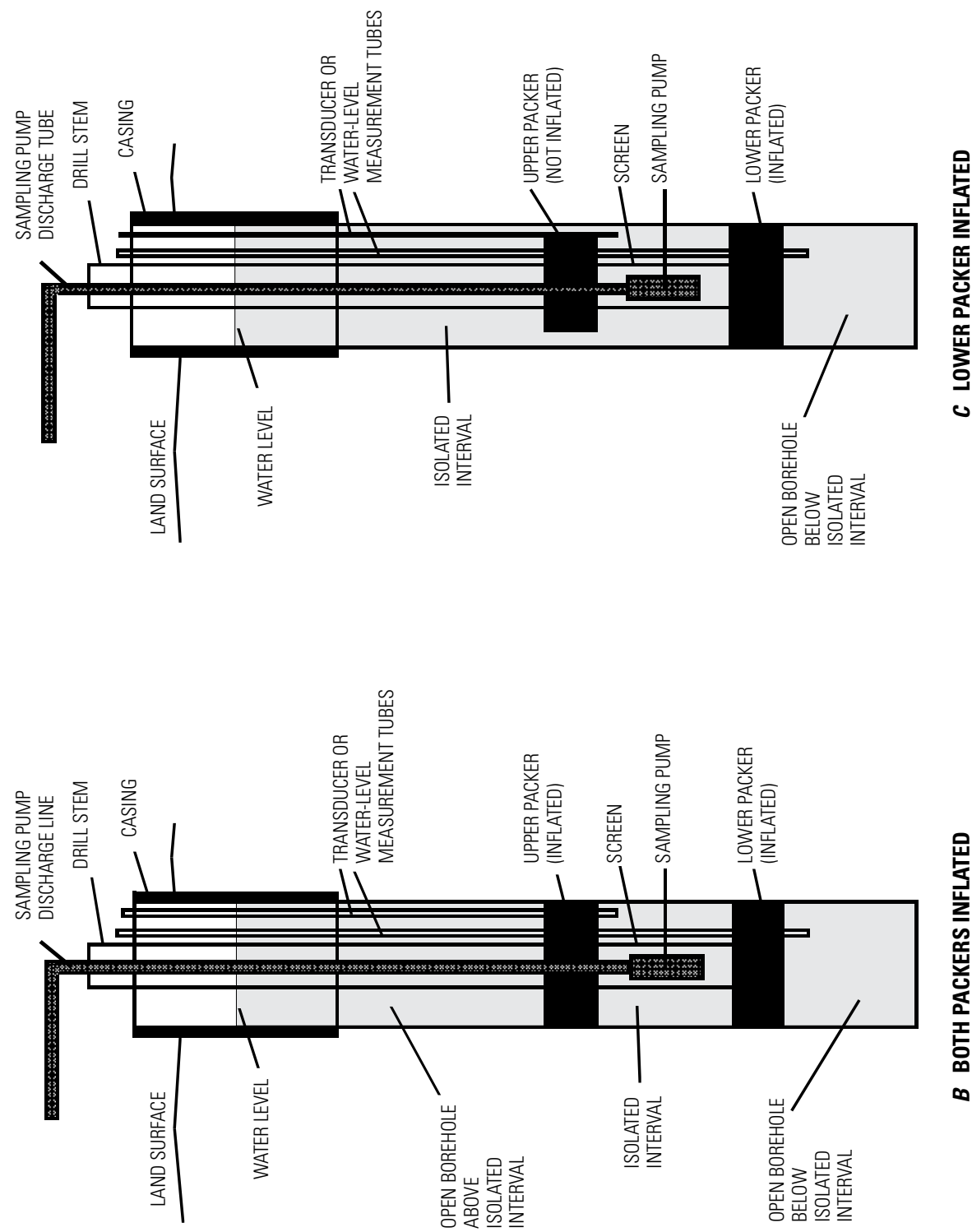

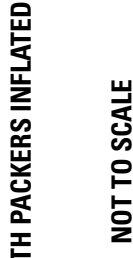

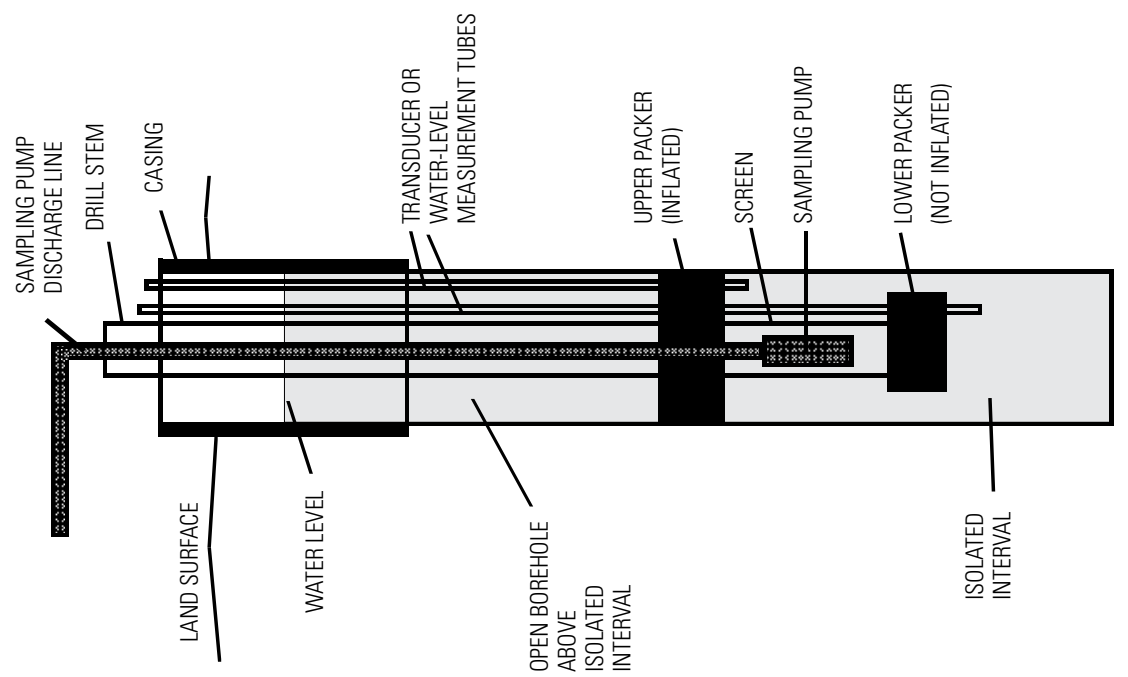

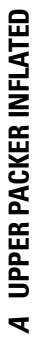


Table 2. Volatile organic compounds analyzed in groundwater samples, Fischer and Porter Superfund Site, Warminster Township, Bucks County, Pennsylvania, 2007-09.

[CAS, Chemical Abstracts Service; $\mu \mathrm{g} / \mathrm{L}$, micrograms per liter]

\begin{tabular}{|c|c|c|c|}
\hline CAS registry number & Compound & $\begin{array}{c}\text { Reporting limit } \\
(\mu \mathrm{g} / \mathrm{L})\end{array}$ & Synonym or abbreviation \\
\hline $71-55-6$ & 1,1,1-Trichloroethane & 0.1 & TCA \\
\hline $76-13-1$ & 1,1,2-Trichlorotrifluoroethane & .1 & Freon 113 \\
\hline $75-34-3$ & 1,1-Dichloroethane & .1 & 1,1-DCA \\
\hline $75-35-4$ & 1,1-Dichloroethylene & .1 & 1,1-DCE \\
\hline $95-50-1$ & 1,2-Dichlorobenzene & .1 & \\
\hline $107-06-2$ & 1,2-Dichloroethane & .2 & 1,2-DCA \\
\hline $156-59-2$ & cis-1,2-Dichloroethylene & .1 & cis-1,2-DCE \\
\hline $156-60-5$ & trans-1,2-Dichloroethylene & .1 & trans-1,2-DCE \\
\hline $78-87-5$ & 1,2-Dichloropropane & .1 & \\
\hline $541-73-1$ & 1,3-Dichlorobenzene & .1 & \\
\hline $106-46-7$ & 1,4-Dichlorobenzene & .1 & \\
\hline $123-91-1$ & 1,4-dioxane ${ }^{1}$ & 2.88 & p-dioxane \\
\hline $67-64-1$ & Acetone & 1.8 & \\
\hline $71-43-2$ & Benzene & .1 & \\
\hline $75-27-4$ & Bromodichloromethane & .1 & \\
\hline $75-25-2$ & Bromoform & .2 & \\
\hline $56-23-5$ & Carbon tetrachloride & .2 & Tetrachloromethane \\
\hline 108-90-7 & Chlorobenzene & .1 & \\
\hline $67-66-3$ & Chloroform & .1 & \\
\hline $124-48-1$ & Dibromochloromethane & .2 & Chlorobromoform \\
\hline $75-71-8$ & Dichlorodifluoromethane & .2 & Freon 12 \\
\hline $75-09-2$ & Dichloromethane & .2 & Methylene chloride \\
\hline $60-29-7$ & Diethyl ether & .2 & \\
\hline 108-20-3 & Diisopropyl ether & .2 & \\
\hline $100-41-4$ & Ethylbenzene & .1 & \\
\hline $637-92-3$ & Ethyl tert-butyl ether & .1 & \\
\hline $79-20-9$ & Methyl acetate & .4 & \\
\hline $994-05-8$ & Methyl-tert-pentyl ether & .2 & \\
\hline $100-42-5$ & Styrene & .1 & \\
\hline $75-65-0$ & Tert-butyl alcohol & 1 & \\
\hline $637-92-3$ & Tert-butyl ethyl ether & .04 & \\
\hline $1634-04-4$ & Tert-butyl methyl ether & .2 & MTBE \\
\hline $127-18-4$ & Tetrachloroethylene & .1 & PCE \\
\hline $108-88-3$ & Toluene & .1 & \\
\hline 79-01-6 & Trichloroethylene & .1 & TCE \\
\hline $75-69-4$ & Trichlorofluoromethane & .2 & Freon 11 \\
\hline $75-01-4$ & Vinyl chloride & .2 & $\mathrm{VC}$ \\
\hline $108-38-3$ & m-Xylene & .2 & \\
\hline
\end{tabular}

${ }^{1}$ Sampled only for the remediation wells. 
Stockton Formation is $6,000 \mathrm{ft}$ thick near the Bucks and Montgomery County boundary; the middle arkose member accounts for 70 percent of its thickness. In the vicinity of the Fischer and Porter Site, the Stockton Formation strikes approximately N. $65^{\circ}$ E. and dips approximately $9^{\circ} \mathrm{NW}$. (Sloto and others, 1992). The rocks are chiefly interbedded arkosic sandstone and siltstone.

\section{Lithostratigraphic Model}

The lithostratigraphic model of the Fischer and Porter Site was developed by Sloto and others (1995). Lithostratigraphic interpretations and correlations were based on the response of borehole geophysical logs collected in on-site boreholes to lithology. Because the lithologic units of the Stockton Formation grade, interfinger, and coalesce, none of the units could be used as marker beds within the lithostratigraphic sequence. The lithology was first interpreted from three continuous rock cores collected at the site. Subsequently, a best fit was made to construct the lithostratigraphic model using the borehole geophysical logs. The interpreted lithology of each borehole was initially developed from correlation with rock cores and then extended along strike or dip to the nextnearest borehole location to correlate lithostratigraphy. Some lithostratigraphic units correlate above or below the expected projection line, probably because of the lens-like structures characteristic of the alluvial-fan depositional environment. Correlations between boreholes generally are consistent with strike and dip but show some thinning and thickening of the units across the area. The accuracy of the correlations deteriorate near land surface because of the absence of singlepoint-resistance measurements and dampened natural-gamma response caused by casing. The lithostratigraphic model was extended off-site using borehole geophysical logs collected in the five off-site boreholes (appendix 2) drilled for this study.

The three-dimensional model of the lithostratigraphy developed by Sloto and others (1995, plates 1-3) was simplified by combining individual lithologic units into generalized sedimentary cycles. Some of the siltstone units are continuous under the entire site and can be traced from borehole to borehole. The areally extensive siltstone units are the tops of poorly defined, upward-fining sedimentary cycles. These cycles were labeled (unit 3, for example) and are called stratigraphic units in this report. Grouping individual beds into sedimentary cycles simplifies the geologic framework and more easily permits tracing of the lithology from borehole to borehole.

The interpreted generalized lithostratigraphy was projected along two lines (A-C and B-C) approximately parallel to the dip direction and one line (D-F) approximately parallel to strike (fig. 4). Section A-C extends southeastward from well BK-3046 to well BK-2514 (fig. 5). Section B-C extends southeastward from well BK-3044 to well BK-2514 (fig. 6). Section D-F extends northeastward from well BK-2511 to well BK-3042 (fig. 7). The cross sections were combined to form a fence diagram for the site (fig. 8).

\section{Hydrology}

The rocks of the Stockton Formation form a complex, heterogeneous, multiaquifer system. This aquifer system is comprised of a series of gently dipping lithologic units with different hydraulic properties. The groundwater system can be visualized as a series of beds with a relatively high transmissivity separated by beds with a relatively low transmissivity. The beds, a few inches to a few feet thick, act as a series of alternating aquifers and confining or semiconfining units that form a leaky, multiaquifer system. Each bed generally has different hydraulic properties, and permeability commonly differs from one bed to another. Lithology and hydraulic properties may change over short horizontal and vertical distances.

In the Stockton Formation, some groundwater moves through intergranular openings in the weathered zone that have formed as a result of weathering. In some places, permeability of the weathered zone may be poor because of a high percentage of clay derived from weathering of siltstone. Most of the groundwater moves through the unweathered zone through a network of interconnecting secondary openingsbedding-plane fractures and joints. Beds within the Stockton Formation are hydraulically connected by steeply dipping joints that cross each other at various angles.

Some water-bearing openings may be slightly enlarged by circulating groundwater that has decomposed and disintegrated mineral constituents in the walls of fractures. Primary porosity that may have originally existed has been almost eliminated by compaction and cementation. Some water may move through intergranular openings in the rock below the weathered zone where the cement has been removed and the permeability has increased, but this generally is restricted to a few coarse-grained sandstone and conglomerate beds. Laboratory hydraulic conductivities were determined for a rock core collected $0.5 \mathrm{mi}$ south of the Fischer and Porter Site. Red siltstone had a hydraulic conductivity of $5.14 \times 10^{-7} \mathrm{ft} / \mathrm{d}$; red, silty, fine-grained sandstone had a hydraulic conductivity of $2.92 \times 10^{-6} \mathrm{ft} / \mathrm{d}$; gray, fine-grained sandstone had a hydraulic conductivity of $1.18 \times 10^{-4} \mathrm{ft} / \mathrm{d}$; and medium- to coarsegrained sandstone (with some cement removed) had a hydraulic conductivity of $0.19 \mathrm{ft} / \mathrm{d}$ (Sloto and others, 1996).

Groundwater generally is unconfined in the shallower part of the aquifer and confined or semiconfined in the deeper part of the aquifer. Differences in the ratio of vertical to horizontal hydraulic conductivity, as well as differences in vertical hydraulic conductivity within and among lithologic units, create confining conditions.

Boreholes may penetrate several water-producing zones with different hydraulic properties. Each water-producing zone usually has a different hydraulic head (water level). The head in a deep, open-hole borehole is the composite of the heads in the water-producing zones penetrated. This can cause heads in some boreholes to be different than heads in adjacent boreholes of different depths. Where differences in head exist between water-producing zones, water flows in the direction of decreasing head. Where the hydraulic head is greater than 


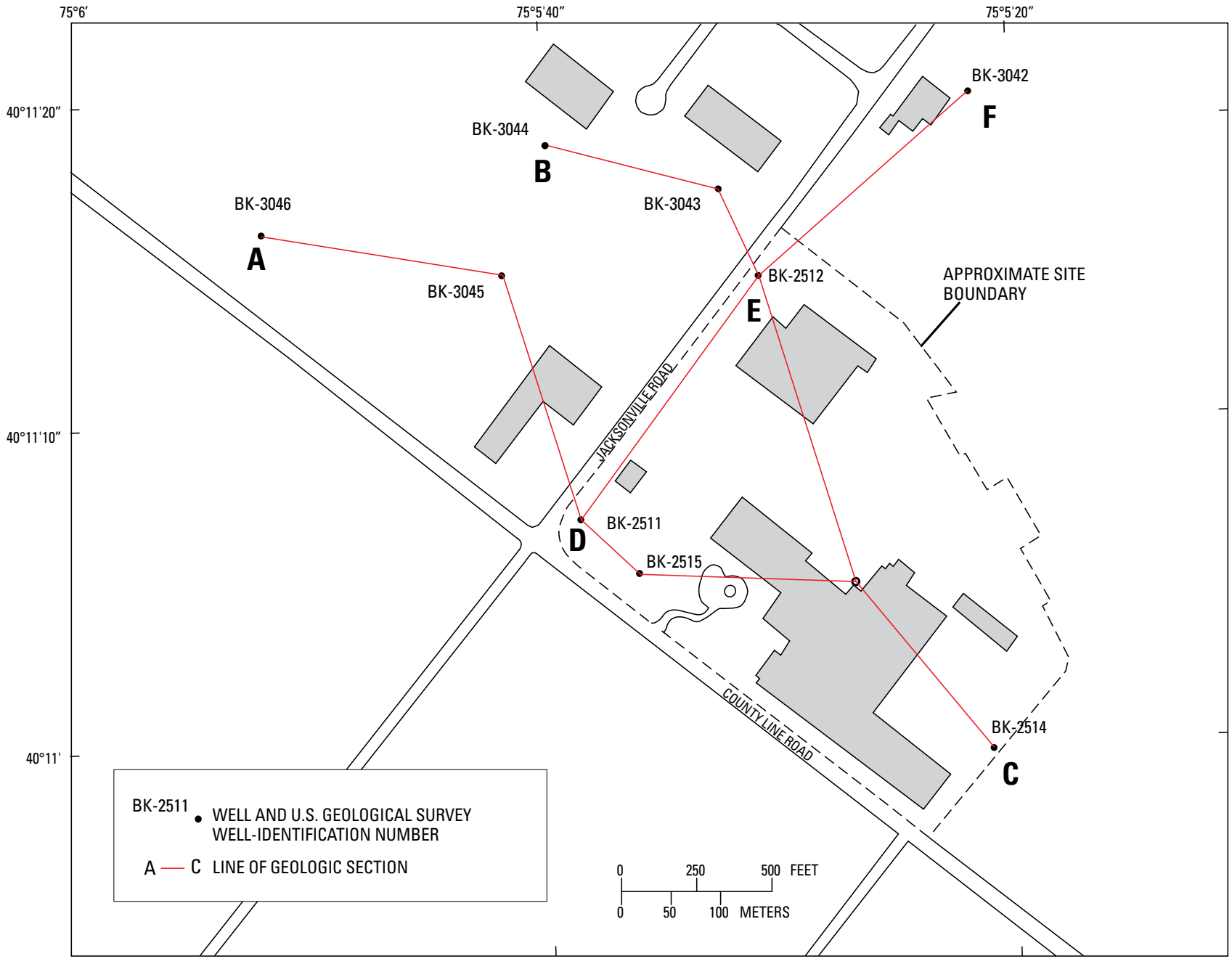

Base from U.S. Geological Survey digital data, 1972, 1:2,000,000 Albers Equal-Area Conic Projection. Standard parallels $29^{\circ} 30^{\prime} \mathrm{N}$, central meridian $75^{\circ} 00^{\prime} \mathrm{W}$.

Figure 4. Location of geologic sections at the Fischer and Porter Superfund Site, Warminster Township, Bucks County, Pennsylvania. 


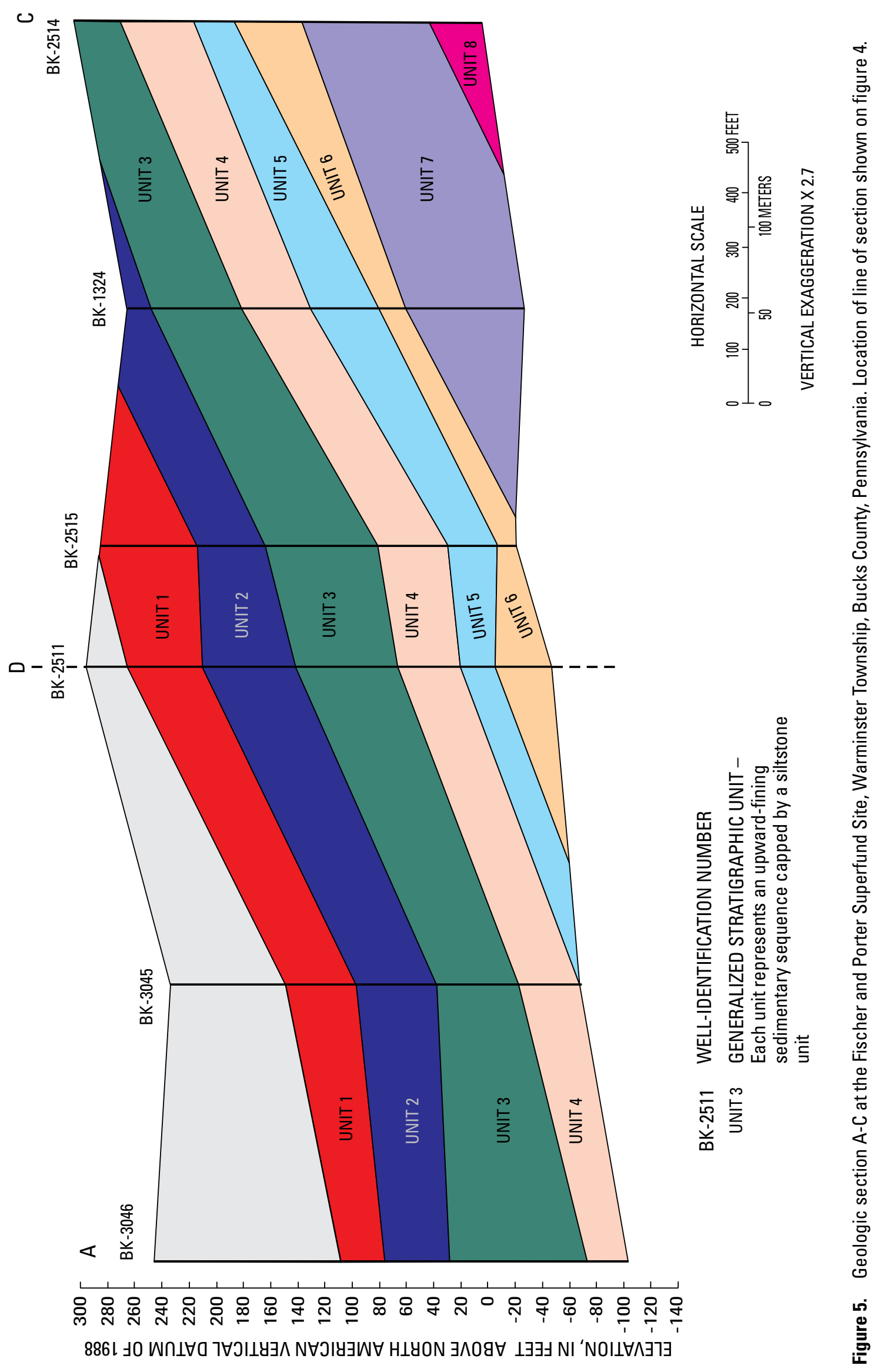




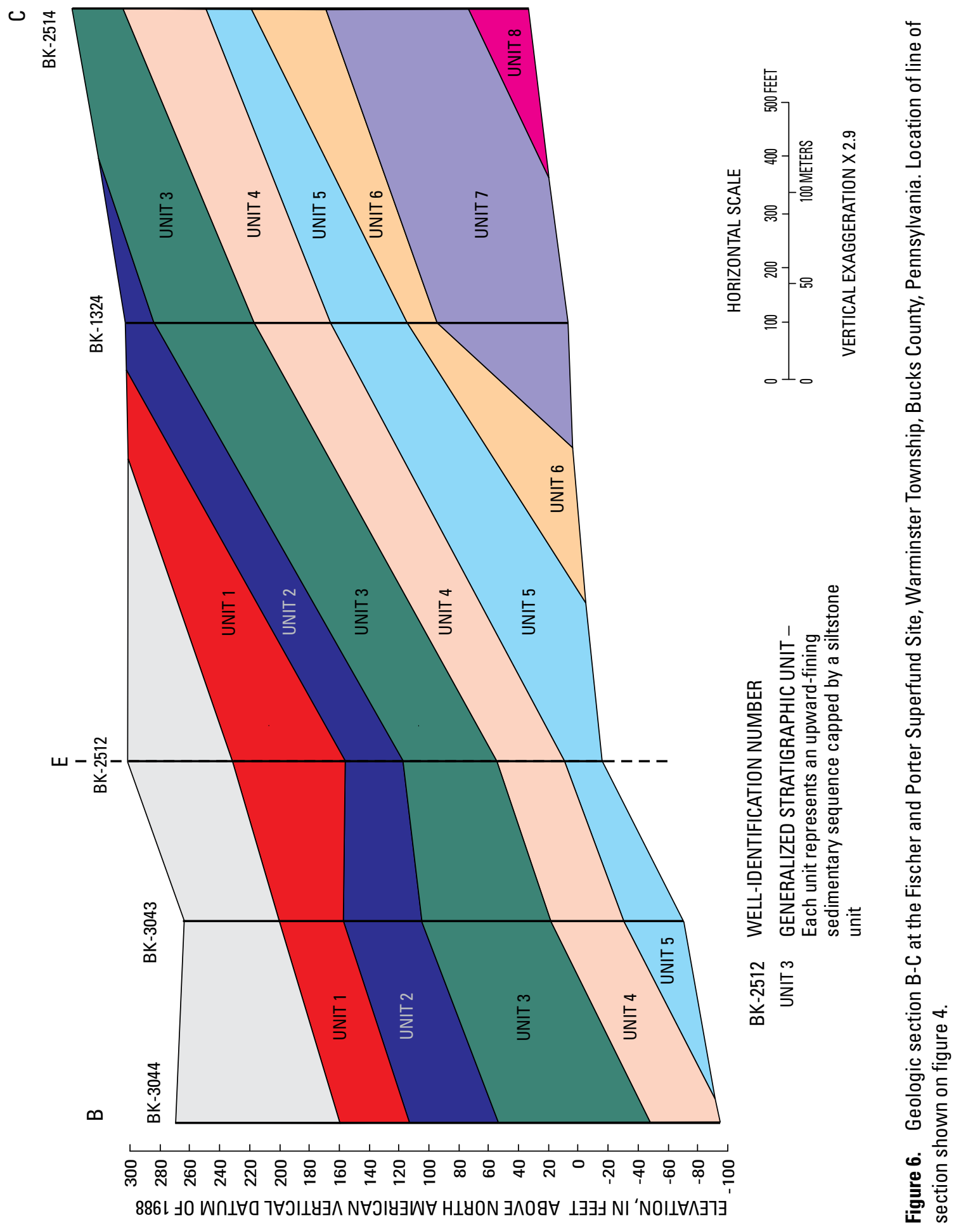




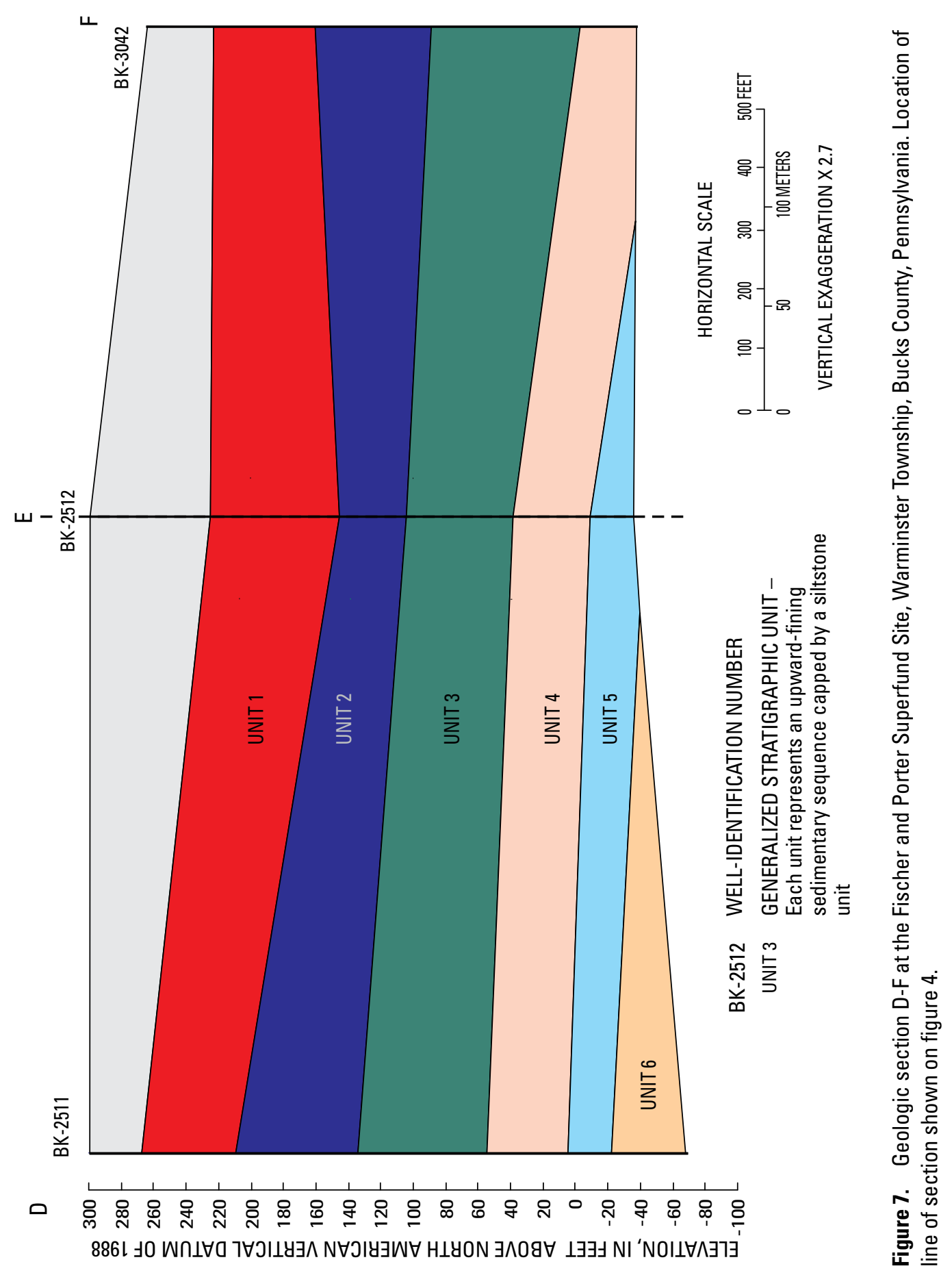




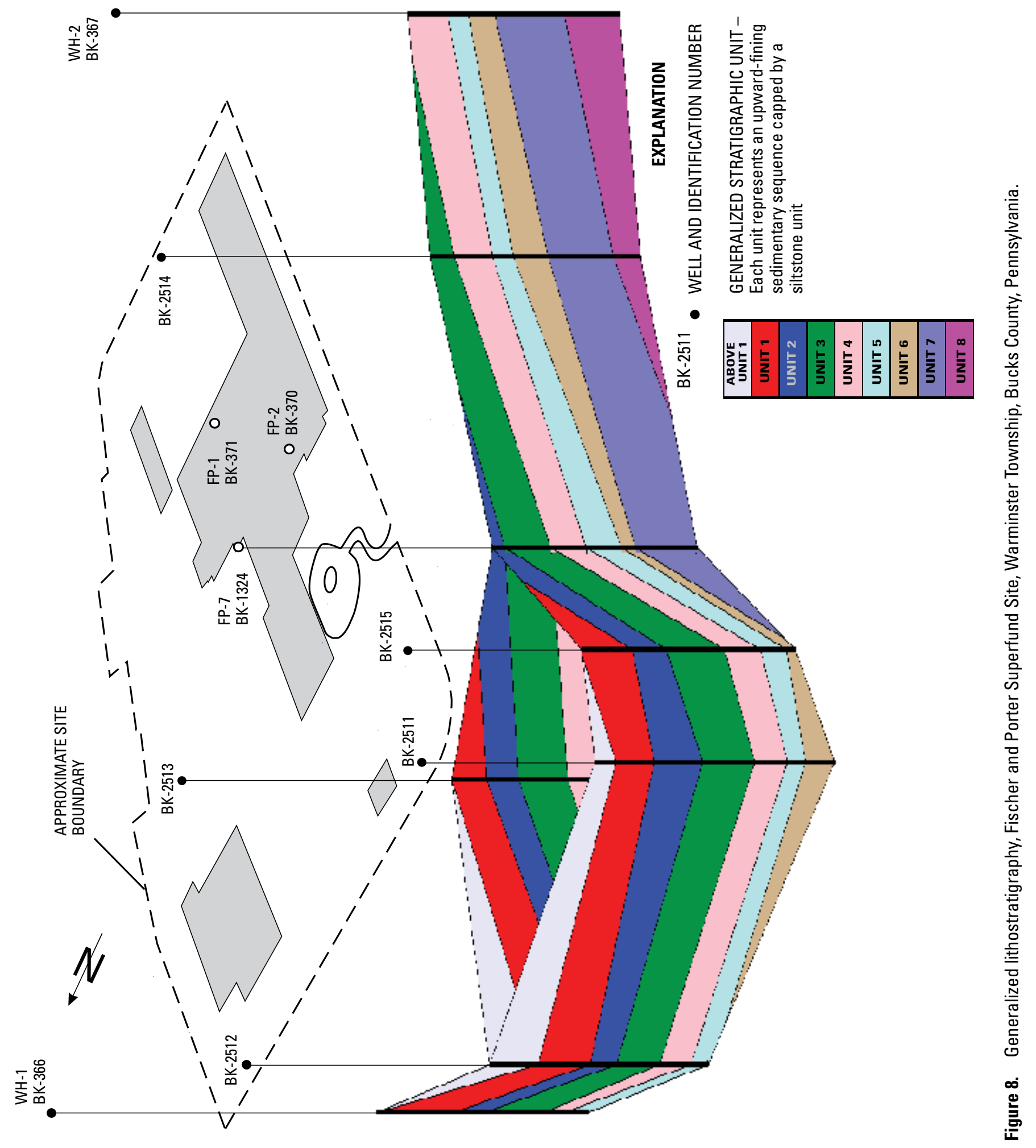


the altitude of the top of the well casing, the well will flow. Boreholes that connect several water-producing zones may act as conduits for the transport of contaminants (Sloto and others, 1996).

Sloto and others (1995) divided the groundwater flow system into shallow, intermediate, and deep zones, which slightly overlap. The shallow zone is considered to be from land surface to less than about $100 \mathrm{ft}$ below land surface, the intermediate-depth zone is considered to be about 100 to $210 \mathrm{ft}$ below land surface, and the deep zone is considered to be greater than about $210 \mathrm{ft}$ below land surface.

\section{Changes in Groundwater Flow}

Pumping wells influence the groundwater system at and in the vicinity of the Fischer and Porter Site. As pumping patterns changed, the pattern of groundwater flow also changed.

\section{Effect of Pumping the Fischer and Porter Remediation Wells}

The combined groundwater pumping rate of the Fischer and Porter remediation-well system is approximately $75 \mathrm{gal} / \mathrm{min}$. Well FP-1 pumps $47 \mathrm{gal} / \mathrm{min}$, well FP-2 pumps $10 \mathrm{gal} / \mathrm{min}$, and well FP-7 pumps $18 \mathrm{gal} / \mathrm{min}$ (CH2M Hill, Inc., 1998). The wells are pumped continuously. A temporary 3-day shutdown of the remediation wells in 1993 (Sloto and others, 1995) had little effect (less than $1 \mathrm{ft}$ of recovery) on shallow groundwater levels (table 3 ). Recovery was as great as $6.9 \mathrm{ft}$ in the deep monitor wells (fig. 9) and $4.3 \mathrm{ft}$ in the intermediate-depth wells (fig. 10). Recovery of water levels in the deep monitor wells was related to direction and distance from the recovery wells. Recovery was greater in the downdip than the updip direction. The direction of greatest recovery in the intermediate-depth wells was about N. $23^{\circ} \mathrm{W}$., which was slightly west of the direction of dip.

Table 3. Changes in water level caused by pumping of the Warminster Heights supply wells and the shutdown of the Fischer and Porter remediation wells, Fischer and Porter Superfund Site, Warminster Township, Bucks County, Pennsylvania. From Sloto and others (1995, p. 35).

[USGS, U.S. Geological Survey; e, estimated]

\begin{tabular}{|c|c|c|c|}
\hline $\begin{array}{c}\text { USGS } \\
\text { well-identification } \\
\text { number }\end{array}$ & $\begin{array}{l}\text { Screened or open interval } \\
\text { (feet below land surface) }\end{array}$ & $\begin{array}{l}\text { Daily change in water level } \\
\text { caused by pumping of } \\
\text { public-supply wells } \\
\text { (feet) }\end{array}$ & $\begin{array}{c}\text { Recovery of water levels caused } \\
\text { by shutdown of the Fischer and } \\
\text { Porter remediation wells } \\
\text { (feet) }\end{array}$ \\
\hline BK-1793 & $23-40$ & .3 & $.5 \mathrm{e}$ \\
\hline BK-1795 & $23-31$ & 0 & $.2 \mathrm{e}^{1}, .4 \mathrm{e}^{2}$ \\
\hline BK-2511 & $300-325$ & .7 & 6.9 \\
\hline BK-2512 & $237-257$ & 5.3 & 2.2 \\
\hline BK-2513 & $255-275$ & 2.3 & 3.1 \\
\hline BK-2514 & $225-250$ & 2.8 & .8 \\
\hline BK-2515 & $285-305$ & .9 & 6.3 \\
\hline BK-2524 & $115-135$ & 5.3 & 1.1 \\
\hline BK-2525 & $31-51$ & 0 & .0 \\
\hline BK-2526 & $50-70$ & 0 & $.9 \mathrm{e}^{2}, 0 \mathrm{e}^{3}$ \\
\hline BK-2527 & $157-187$ & 2.6 & 3.3 \\
\hline BK-2528 & $25-45$ & .1 & $.4 \mathrm{e}$ \\
\hline
\end{tabular}

${ }^{1}$ Estimated for the December 13-15, 1993, shutdown.

${ }^{2}$ Estimated for the May 16-19, 1994, shutdown.

${ }^{3}$ Estimated for the April 27-29, 1994, shutdown. 


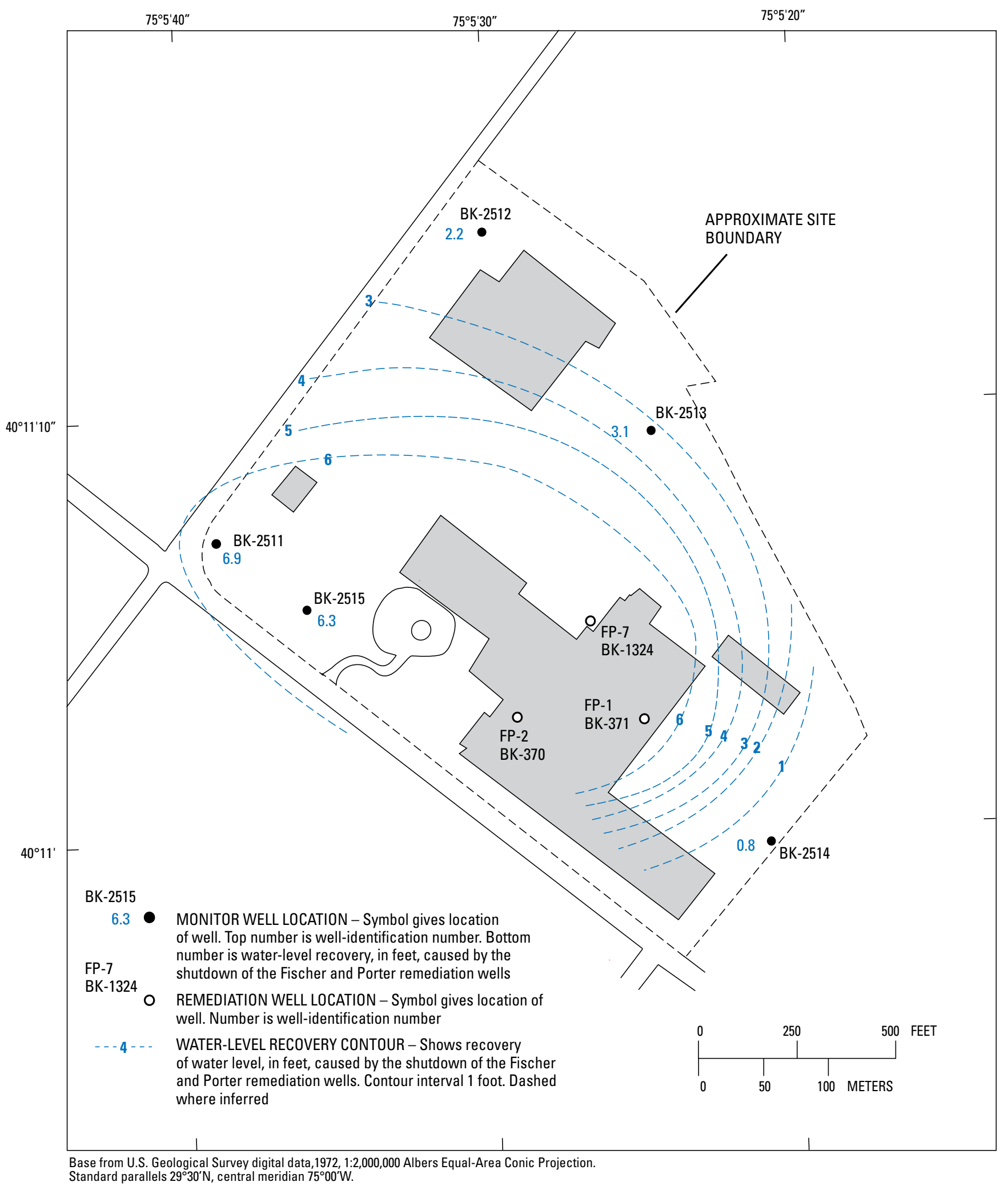

Figure 9. Recovery of water levels in deep wells caused by the 1993-94 shutdowns of the remediation wells, Fischer and Porter Superfund Site, Warminster Township, Bucks County, Pennsylvania. 


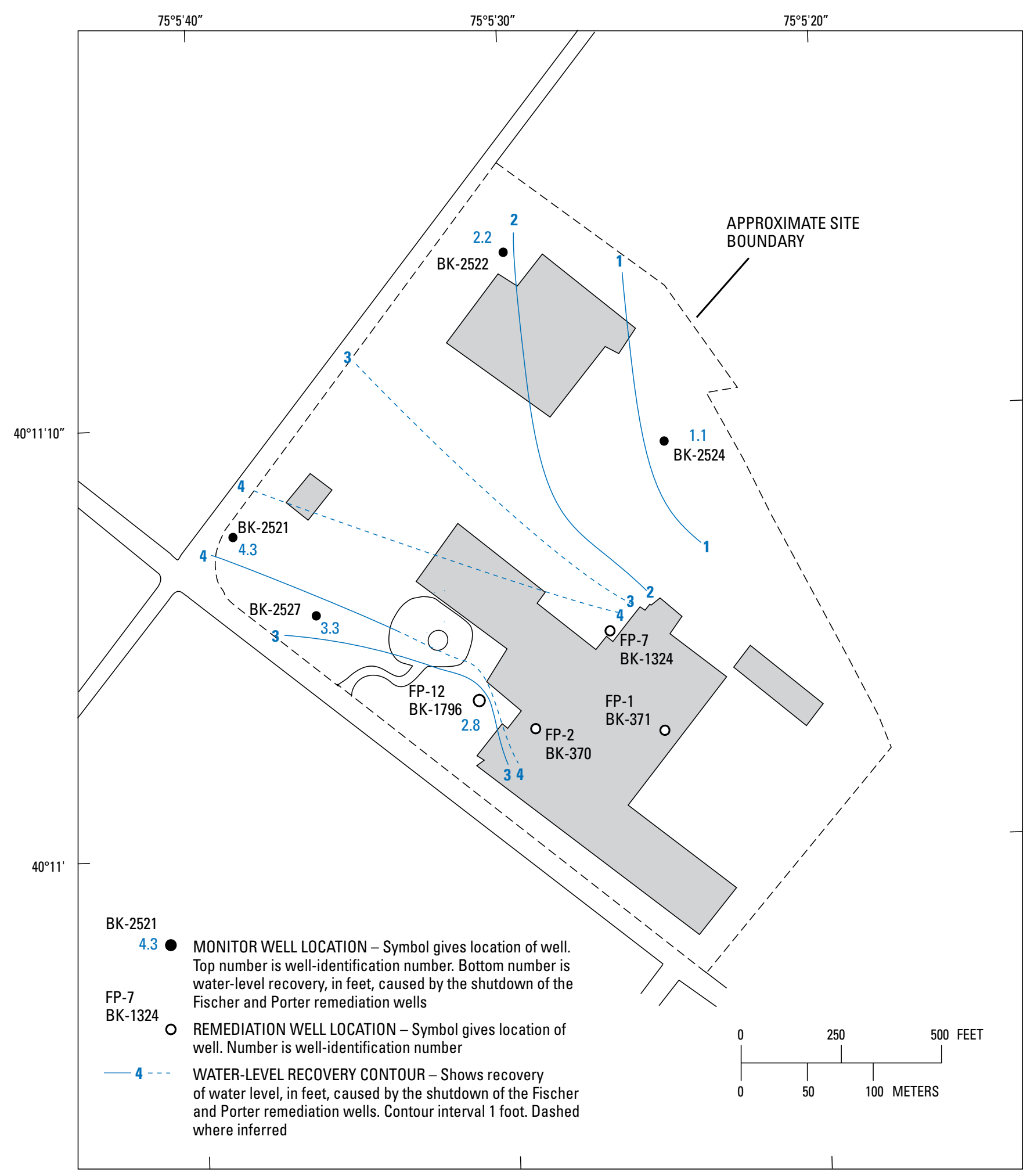

Base from U.S. Geological Survey digital data,1972, 1:2,000,000 Albers Equal-Area Conic Projection. Standard parallels $29^{\circ} 30^{\prime} \mathrm{N}$, central meridian $75^{\circ} 00^{\prime} \mathrm{W}$.

Figure 10. Recovery of water levels in intermediate-depth wells caused by the 1993-94 shutdowns of the remediation wells, Fischer and Porter Superfund Site, Warminster Township, Bucks County, Pennsylvania. 


\section{Effect of Pumping Public-Supply Wells}

The Warminster Heights supply wells (WH-1 and WH-2) stopped pumping around November 2004. When pumping, the wells exerted a considerable influence on water levels at the Fischer and Porter Site (table 3). The capacity of the pumps averaged $285 \mathrm{gal} / \mathrm{min}$ (CH2M Hill, Inc., 1998). Well WH-1 penetrates stratigraphic units 1 through 5 , and well WH-2 penetrates stratigraphic units 4 through 8 (fig. 8). Pumping of the Warminster Heights wells had little effect on the shallow groundwater system (table 3); the water-level change was $1.7 \mathrm{ft}$ in well BK-2523 and $0.3 \mathrm{ft}$ or less in the other shallow wells. The pumping of well WH-2 affected only the southeastern part of the site and affected only well BK-2514 (fig. 11). The pumping of well WH-1 caused a maximum daily fluctuation of $5.3 \mathrm{ft}$ in the deep monitor wells (fig. 11) and the intermediate-depth wells (fig. 12). The pumping of well WH-1 affected water levels most strongly along strike and downdip.

\section{Horizontal Groundwater Gradients}

Water-level data were collected by the USGS in 1993-94 (Sloto and others, 1995) and in 2006-09 and by CH2M Hill, Inc. (1998) in 1996. During water-level-data collection in 1993-94 and 1996, the Warminster Heights wells were pumping. During water-level-data collection in 2006-09, the Warminster Heights wells were not pumping. Water levels measured at the Fischer and Porter Site for 2006-09 are presented in table 4.

Potentiometric-surface maps were published by Sloto and others (1995) for December 13, 1993, and May 3, 1994, with the Warminster Heights and Fischer and Porter remediation wells pumping. Potentiometric-surface maps were published by CH2M Hill, Inc. (1998) for March 18, 1996, with the Warminster Heights wells operating and the Fischer and Porter remediation wells not pumping, and for April 2, 1996, with the Warminster Heights wells and Fischer and Porter remediation wells FP-1 and FP-2 pumping. In 1993-94 (Sloto and others, 1995, p. 42) and 1996 (CH2M Hill, Inc., 1998, p. 3-18 and 3-21), the direction of groundwater flow generally was towards the north.

For this study, water levels were measured in shallow wells on September 15, 2006 (fig. 13), January 16-20, 2007 (fig. 14), and May 21-22, 2009 (fig. 15). The Fischer and Porter remediation wells were pumping on all three dates. On all three dates, the direction of groundwater flow was to the north-northwest. It is about the same direction as the previous (1993-94 and 1996) potentiometric-surface maps for the shallow zone. Horizontal gradients also were about the same. A groundwater divide to the north of the remediation wells is apparent on the shallow potentiometric-surface maps for September 2006, January 2007, and May 2009. This divide is caused by the pumping of the remediation wells. The shutdown of the Warminster Heights wells had little effect on the direction of groundwater flow in the shallow zone.
For this study, water levels were measured in intermediate-depth wells on September 15, 2006 (fig. 16), January 16-20, 2007 (fig. 17), and May 21-22, 2009 (fig. 18). The potentiometric-surface maps for January 2007 and May 2009 include water levels measured in the Warminster Heights wells. The Warminster Heights wells are open-hole wells, and the water level is a composite of the water levels in the water-bearing fractures penetrated by the well. The maps for 2007 and 2009 (figs. 17 and 18) show the direction of groundwater flow is to the northwest. This differs from previously mapped groundwater-flow directions, which generally were to the north in 1993-94 (Sloto and others, 1995, p. 42) and 1996 (CH2M Hill, Inc., 1998, p. 3-19 and 3-21) when Warminster Heights well WH-1 was pumping. The direction of groundwater flow in the intermediate-depth zone shifted from the north to the northwest after well WH-1 stopped pumping. The horizontal gradient on the northern side of the site was 0.023 in January 2007 and May 2009. A horizontal hydraulic gradient could not be determined for September 2006. The horizontal hydraulic gradient on the northern side of the site was 0.017 in March 1996 and 0.014 in April 1996. The horizontal hydraulic gradient on the northern side of the site was an order of magnitude less in December 1993 (0.005) and May 1994 (0.003). The horizontal hydraulic gradient has become slightly steeper in the intermediate-depth zone since well WH-1 stopped pumping.

For this study, water levels were measured in deep wells on September 15, 2006 (fig. 19), January 16-20, 2007 (fig. 20), and May 21-22, 2009 (fig. 21). The map for January 16-20, 2007, includes water levels measured in the Warminster Heights wells on February 22, 2007. The map for May 21-22, 2009, includes water levels measured in the Warminster Heights wells and the new off-site monitor wells. On all three dates, the general direction of groundwater flow was to the northwest. A groundwater divide is apparent on the southeastern side of the site on the January 16-20, 2007, map (fig. 20). This divide approximately coincides with the topographic divide between tributaries to Pennypack Creek on the northwestern side of the divide and tributaries to Southampton Creek on the southeastern side of the divide.

The direction of groundwater flow in the deep zone was to the west and southwest in 1993-94 (Sloto and others, 1995, p. 42) and to the northeast toward Warminster Heights well WH-1 in 1996 (CH2M Hill, Inc., 1998, p. 3-19 and 3-21). After well WH-1 stopped pumping, the direction of groundwater flow changed to the northwest (fig. 21).

The horizontal hydraulic gradient in the deep zone is fairly flat on the north and northwestern sides of the site. On September 15, 2006, the difference in water-level altitude among the four deep monitor wells (BK-2511, BK-2512, BK-2513, and BK-2515) was only $0.91 \mathrm{ft}$, and the horizontal gradient was 0.002. On January 16-20, 2007, the difference in water-level altitude among the four deep monitor wells was $1.61 \mathrm{ft}$, and the horizontal hydraulic gradient was 0.009 . On May 21-22, 2009, the difference in water-level altitude among the four deep monitor wells was $4.97 \mathrm{ft}$, and the horizontal 


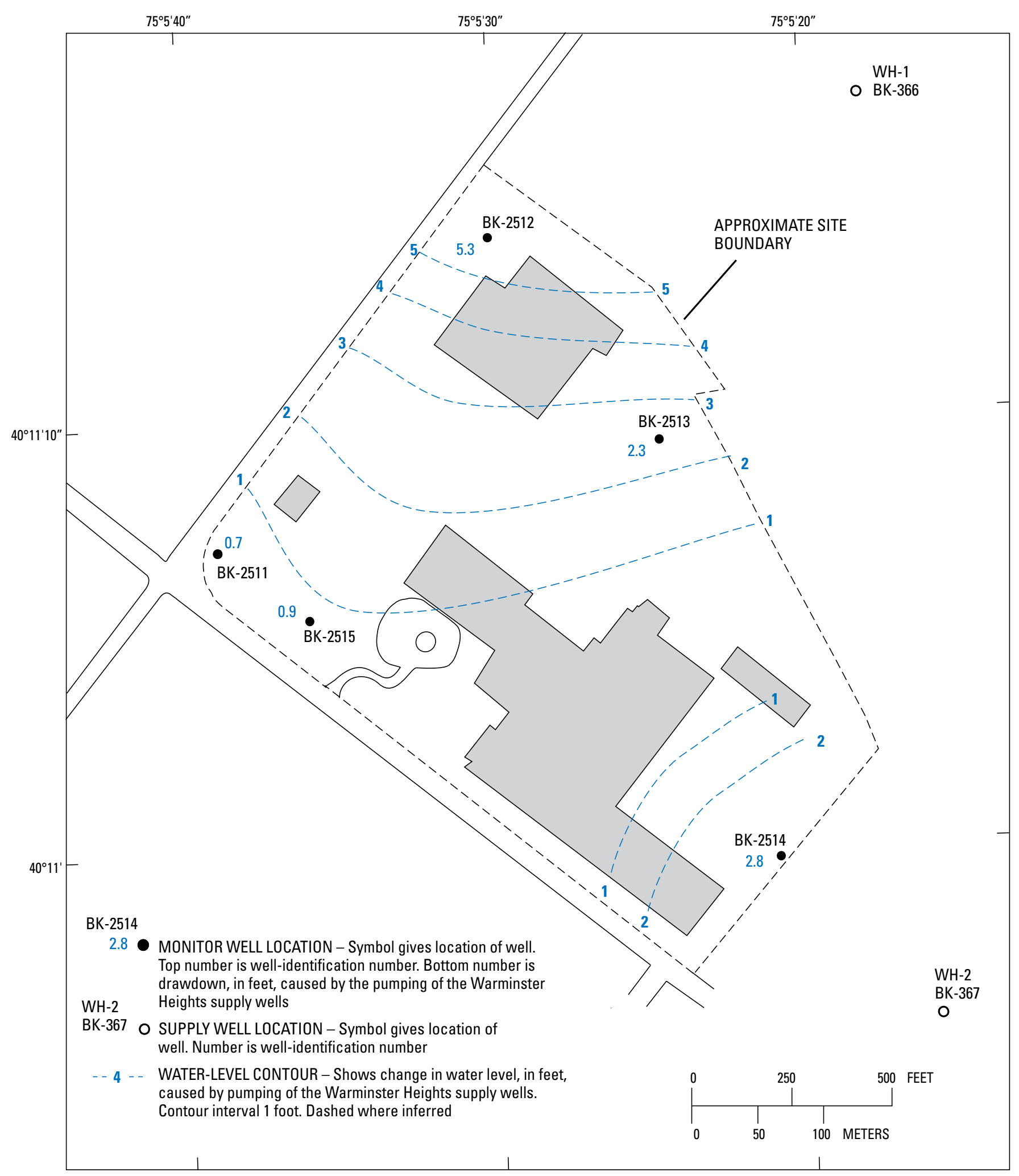

Base from U.S. Geological Survey digital data,1972, 1:2,000,000 Albers Equal-Area Conic Projection. Standard parallels $29^{\circ} 30^{\prime} \mathrm{N}$, central meridian $75^{\circ} 00^{\prime} \mathrm{W}$.

Figure 11. Change in water level in deep wells caused by the pumping of the Warminster Heights supply wells, Fischer and Porter Superfund Site, Warminster Township, Bucks County, Pennsylvania, 1993-94. 


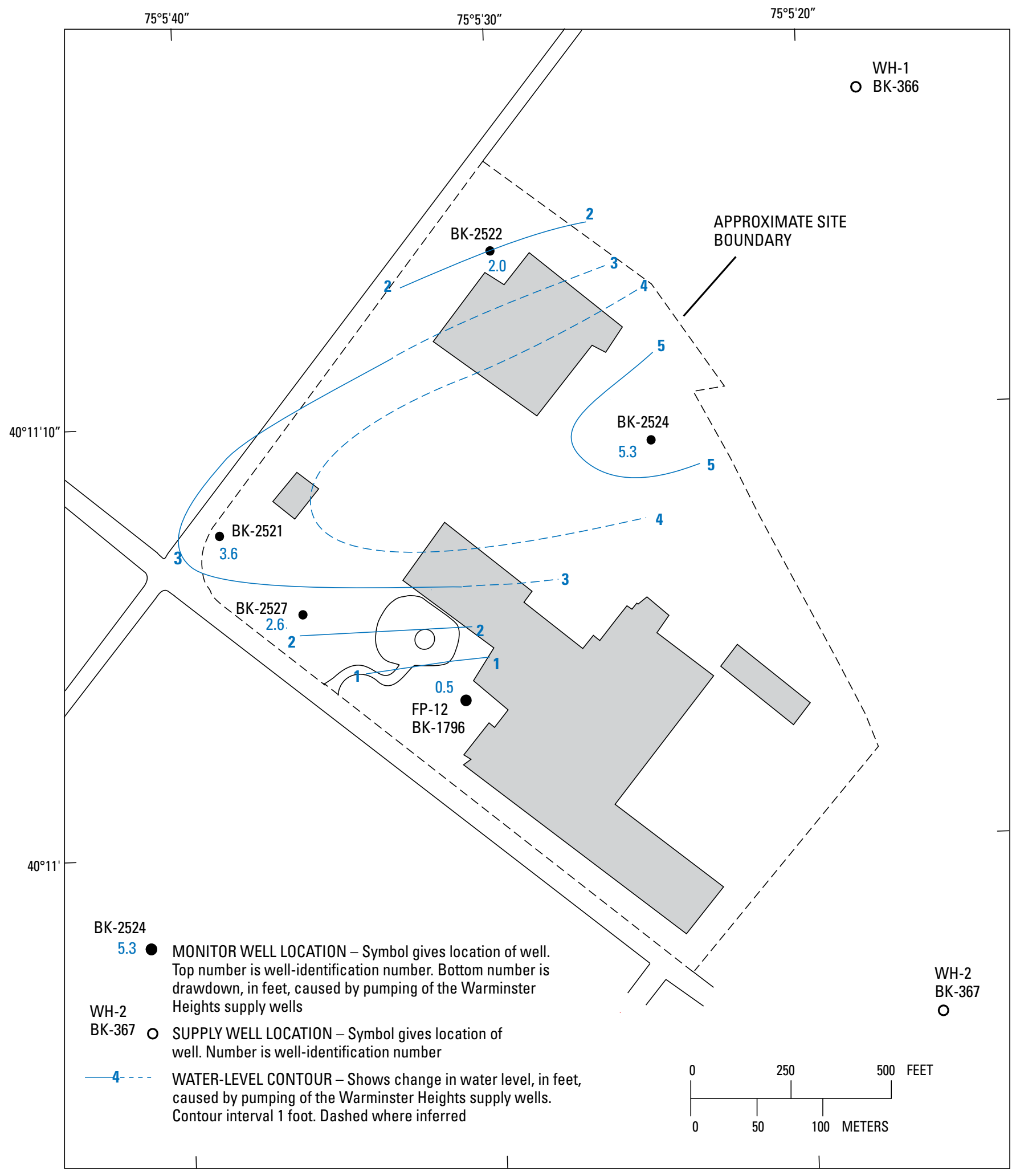

Base from U.S. Geological Survey digital data,1972, 1:2,000,000 Albers Equal-Area Conic Projection. Standard parallels $29^{\circ} 30^{\prime} \mathrm{N}$, central meridian $75^{\circ} 00^{\prime} \mathrm{W}$.

Figure 12. Change in water level in intermediate-depth wells caused by the pumping of the Warminster heights supply wells, Fischer and Porter Superfund Site, Warminster Township, Bucks County, Pennsylvania. 
Table 4. Water levels measured at the Fischer and Porter Superfund Site, Warminster Township, Bucks County, Pennsylvania, 2006-09.

[USGS, U.S. Geological Survey; >, greater than (well flowing); --. water level not measured]

\begin{tabular}{|c|c|c|c|}
\hline \multirow{2}{*}{$\begin{array}{c}\text { USGS } \\
\text { well-identification } \\
\text { number }\end{array}$} & \multicolumn{3}{|c|}{ Water-level elevation (feet above NAVD 88) } \\
\hline & September 15, 2006 & January 16-20, 2007 & May 21-22, 2009 \\
\hline BK-366 & -- & 1265.22 & 276.10 \\
\hline BK-367 & -- & 1258.99 & 276.99 \\
\hline BK-371 & -- & 228.35 & 234.92 \\
\hline BK-1030 & -- & 1257.45 & $>261$ \\
\hline BK-1324 & -- & 203.70 & 261.02 \\
\hline BK-1731 & 271.78 & 273.27 & 272.75 \\
\hline BK-1793 & 275.96 & 277.88 & 277.63 \\
\hline BK-2511 & 266.74 & 270.98 & 267.55 \\
\hline BK-2512 & 265.83 & 269.37 & 267.61 \\
\hline BK-2513 & 266.44 & 270.94 & 272.52 \\
\hline BK-2514 & 271.27 & 274.95 & 272.26 \\
\hline BK-2515 & 266.72 & 270.08 & 267.68 \\
\hline BK-2521 & 263.62 & 267.57 & 269.54 \\
\hline BK-2522 & 261.11 & 259.33 & 270.08 \\
\hline BK-2523 & 256.88 & 259.61 & 265.90 \\
\hline BK-2524 & 269.22 & 273.59 & 277.24 \\
\hline BK-2525 & 272.21 & 273.20 & 274.45 \\
\hline BK-2526 & 279.82 & 286.47 & 284.37 \\
\hline BK-2527 & 259.45 & 263.30 & 277.53 \\
\hline BK-2528 & 273.94 & 275.42 & 275.04 \\
\hline BK-2810 & 267.11 & 271.17 & 272.63 \\
\hline BK-2811 & 273.16 & 274.61 & 274.26 \\
\hline BK-2827 & 272.74 & 277.02 & 265.05 \\
\hline BK-3042 & -- & -- & 263.71 \\
\hline BK-3043 & -- & -- & 256.35 \\
\hline BK-3045 & -- & -- & 259.60 \\
\hline BK-3046 & -- & -- & 209.96 \\
\hline
\end{tabular}

${ }^{1}$ Water level measured on February 22, 2007. 


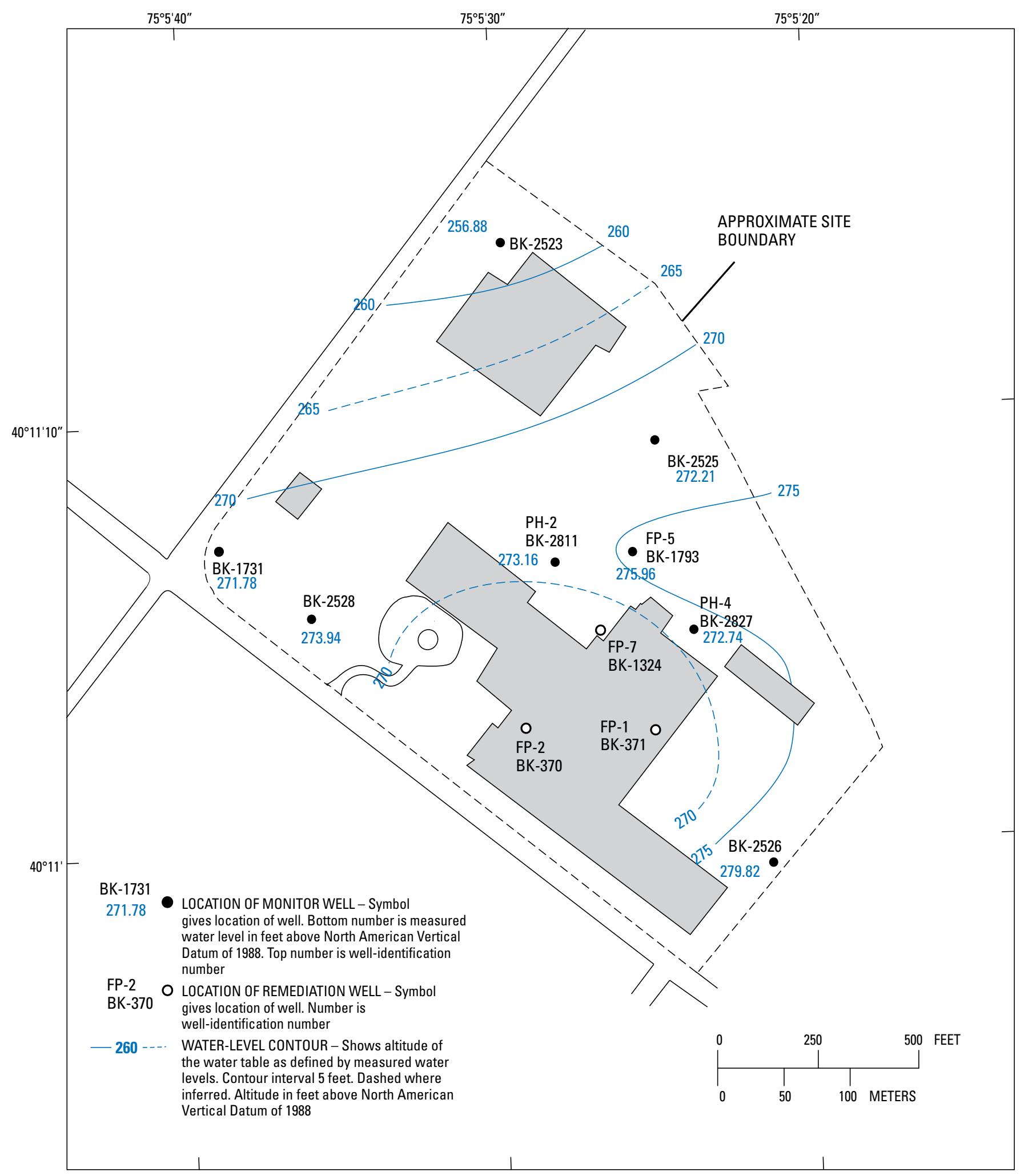

Base from U.S. Geological Survey digital data,1972, 1:2,000,000 Albers Equal-Area Conic Projection. Standard parallels $29^{\circ} 30^{\prime} \mathrm{N}$, central meridian $75^{\circ} 00^{\prime} \mathrm{W}$.

Figure 13. Potentiometric surface measured in wells screened in the shallow zone at the Fischer and Porter Superfund Site, Warminster Township, Bucks County, Pennsylvania, September 15, 2006. 


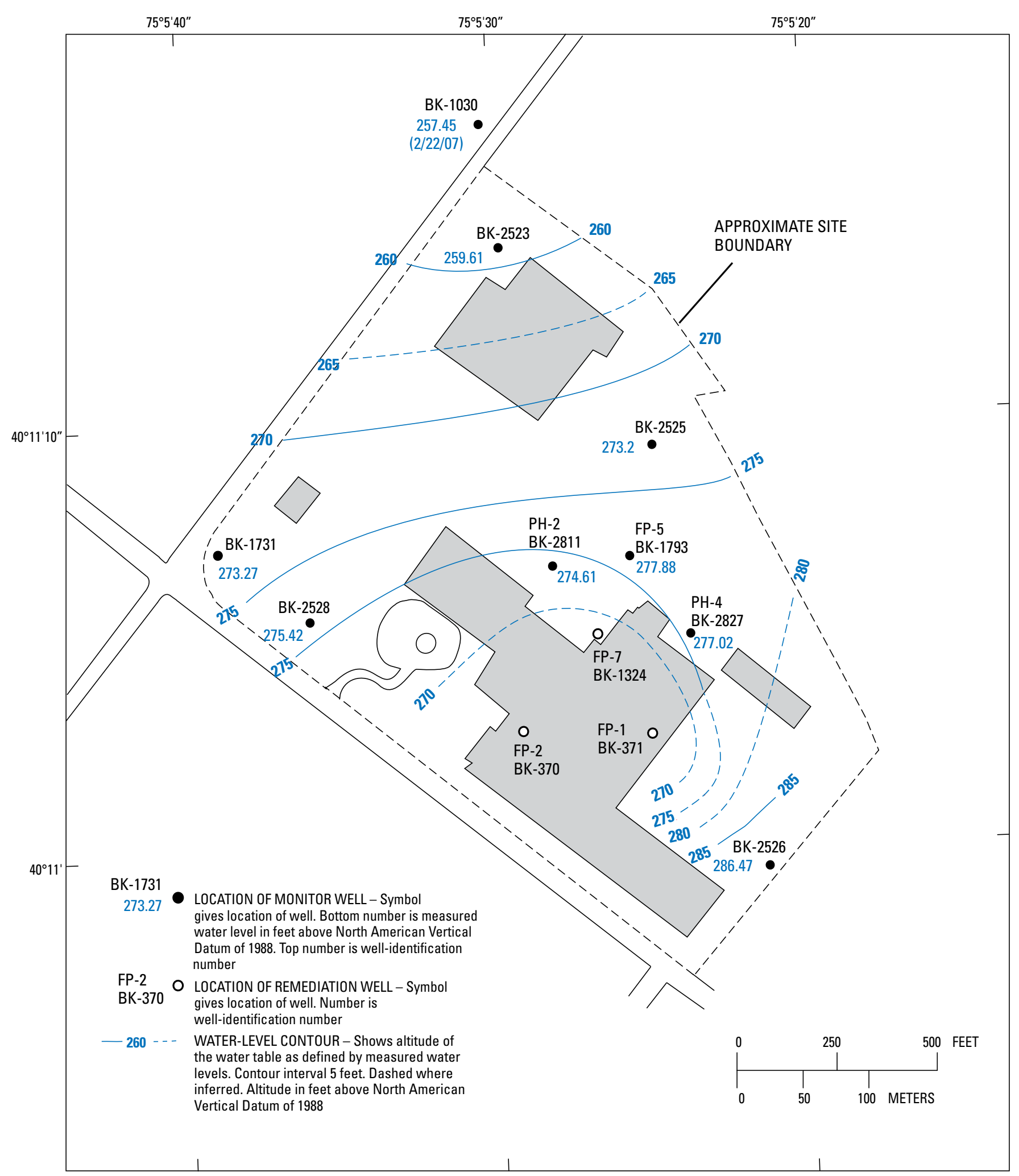

Base from U.S. Geological Survey digital data,1972, 1:2,000,000 Albers Equal-Area Conic Projection.

Standard parallels $29^{\circ} 30^{\prime} \mathrm{N}$, central meridian $75^{\circ} 00^{\prime} \mathrm{W}$.

Figure 14. Potentiometric surface measured in wells screened in the shallow zone at the Fischer and Porter Superfund Site, Warminster Township, Bucks County, Pennsylvania, January 16-20, 2007. 


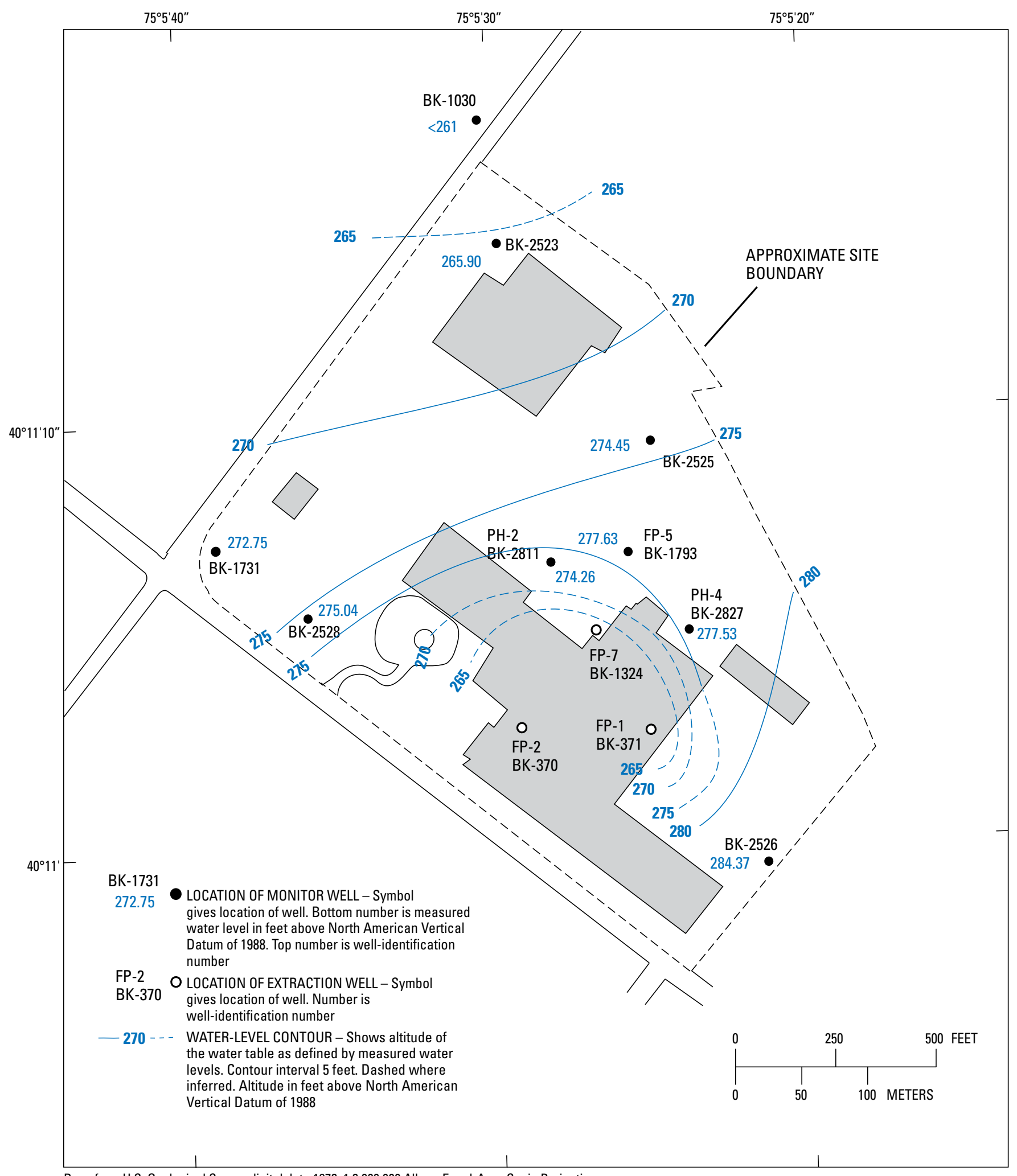

Base from U.S. Geological Survey digital data, 1972, 1:2,000,000 Albers Equal-Area Conic Projection. Standard parallels $29^{\circ} 30^{\prime} \mathrm{N}$, central meridian $75^{\circ} 00^{\prime} \mathrm{W}$.

Figure 15. Potentiometric surface measured in wells screened in the shallow zone at the Fischer and Porter Superfund Site, Warminster Township, Bucks County, Pennsylvania, May 21-22, 2009. 


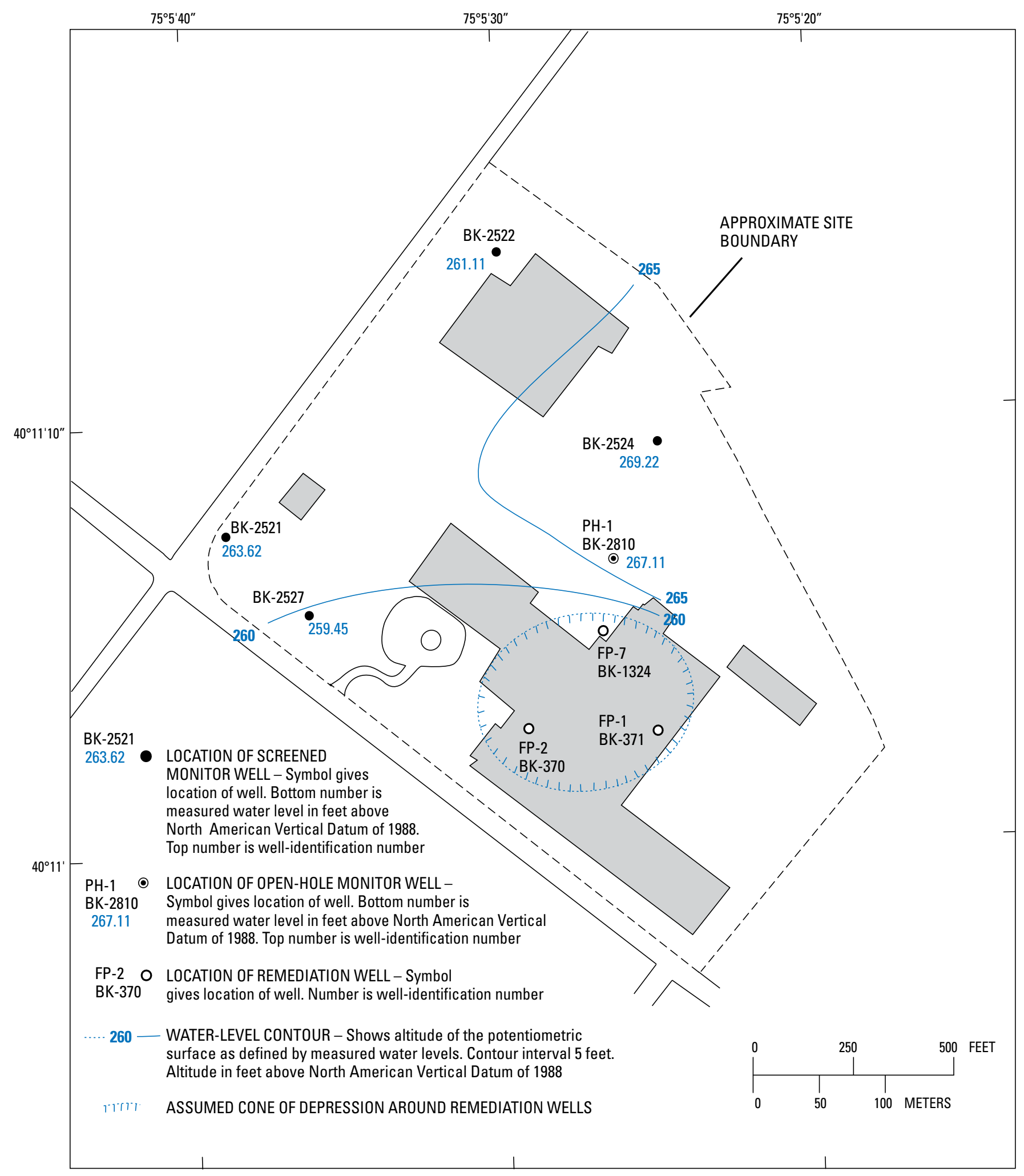

Base from U.S. Geological Survey digital data,1972, 1:2,000,000 Albers Equal-Area Conic Projection.

Standard parallels $29^{\circ} 30^{\prime} \mathrm{N}$, central meridian $75^{\circ} 00^{\prime} \mathrm{W}$.

Figure 16. Potentiometric surface measured in wells screened in the intermediate zone at the Fischer and Porter Superfund Site, Warminster Township, Bucks County, Pennsylvania, September 15, 2006. 


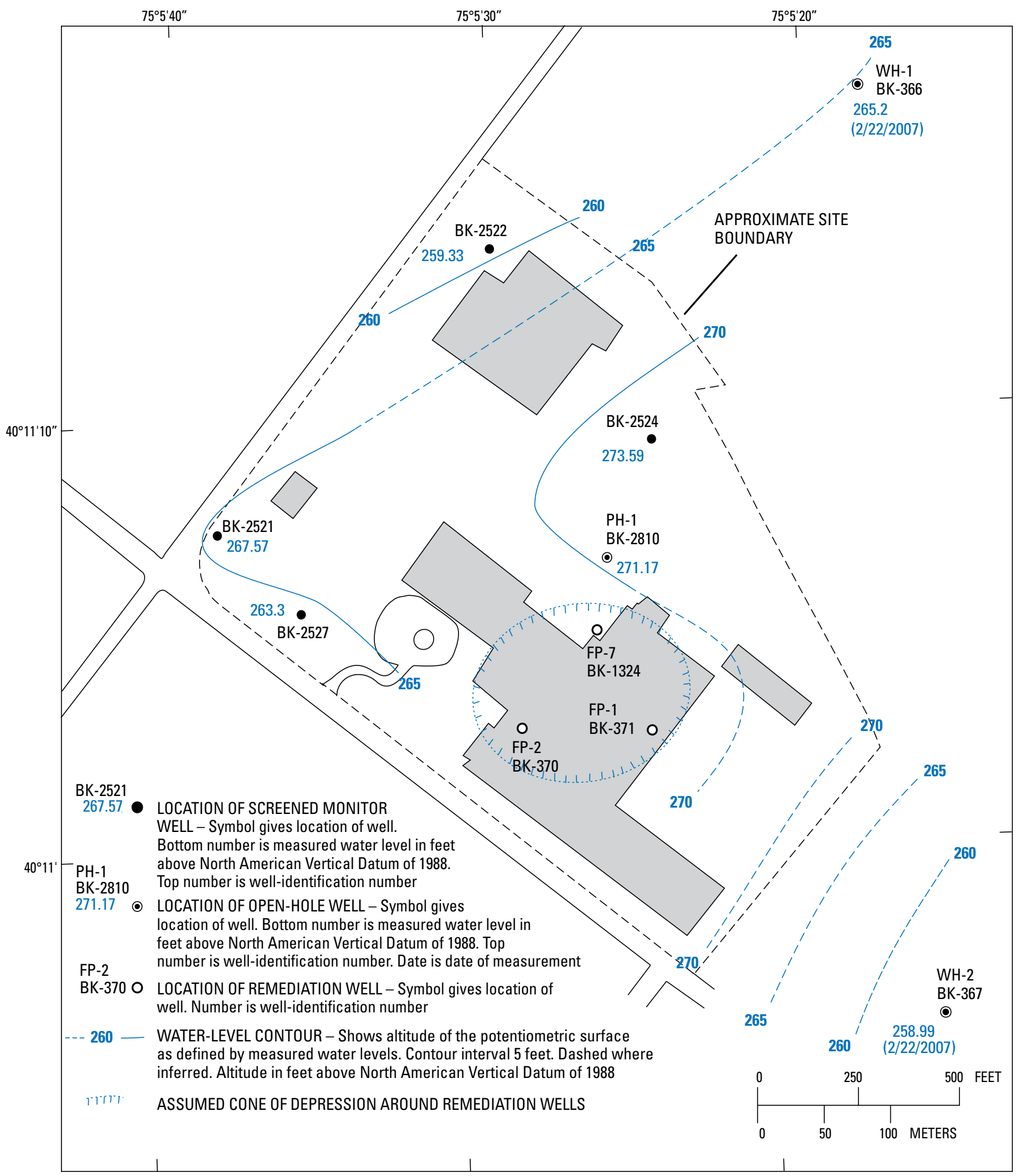

Base from U.S. Geological Survey digital data,1972, 1:2,000,000 Albers Equal-Area Conic Projection. Standard parallels $29^{\circ} 30^{\prime} \mathrm{N}$, central meridian $75^{\circ} 00^{\prime} \mathrm{W}$.

Figure 17. Potentiometric surface measured in wells screened in the intermediate zone at the Fischer and Porter Superfund Site, Warminster Township, Bucks County, Pennsylvania, January 16-20, 2007. 


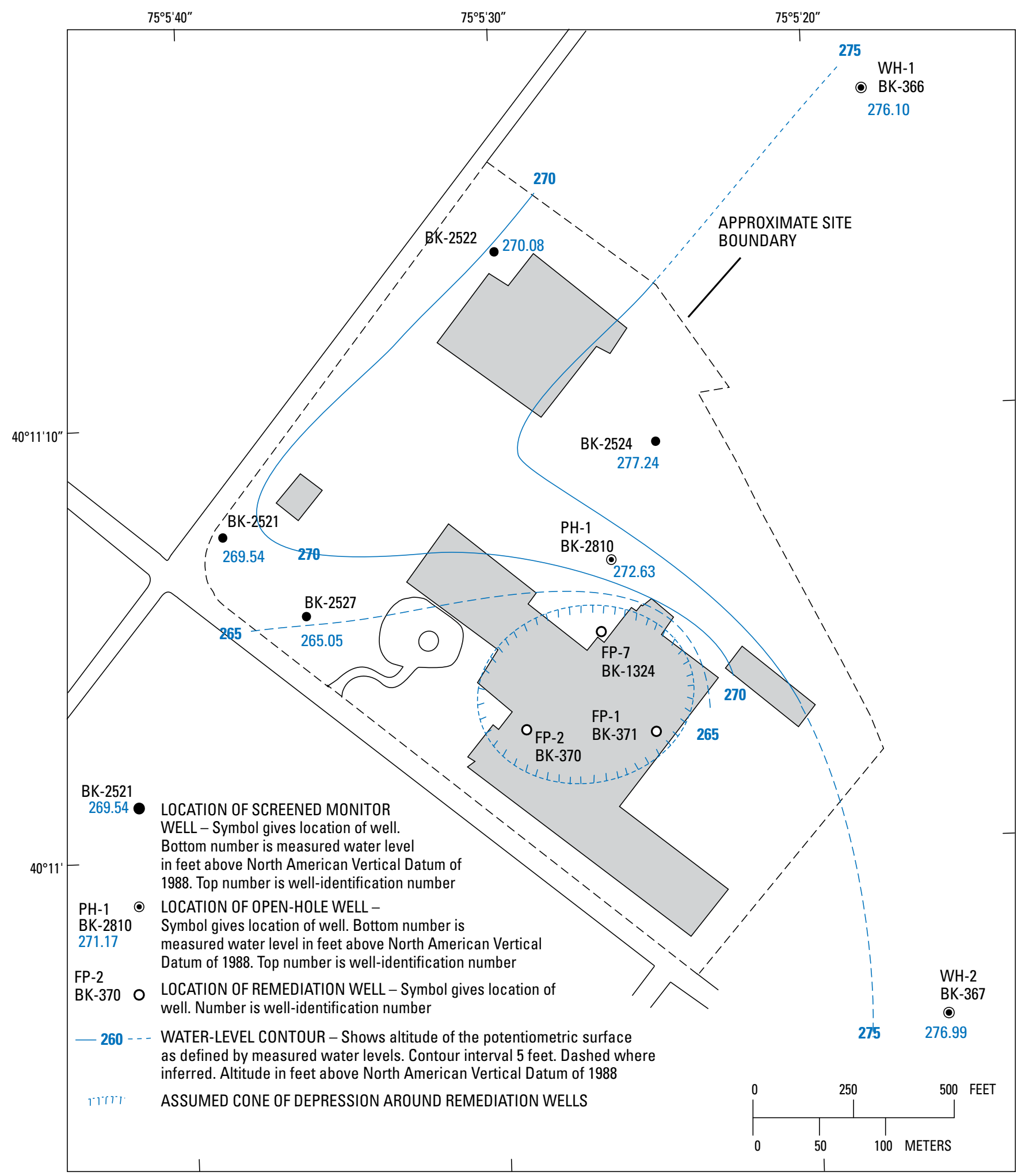

Base from U.S. Geological Survey digital data,1972, 1:2,000,000 Albers Equal-Area Conic Projection.

Standard parallels $29^{\circ} 30^{\prime} \mathrm{N}$, central meridian $75^{\circ} 00^{\prime} \mathrm{W}$.

Figure 18. Potentiometric surface measured in wells screened in the intermediate zone at the Fischer and Porter Superfund Site, Warminster Township, Bucks County, Pennsylvania, May 21-22, 2009. 


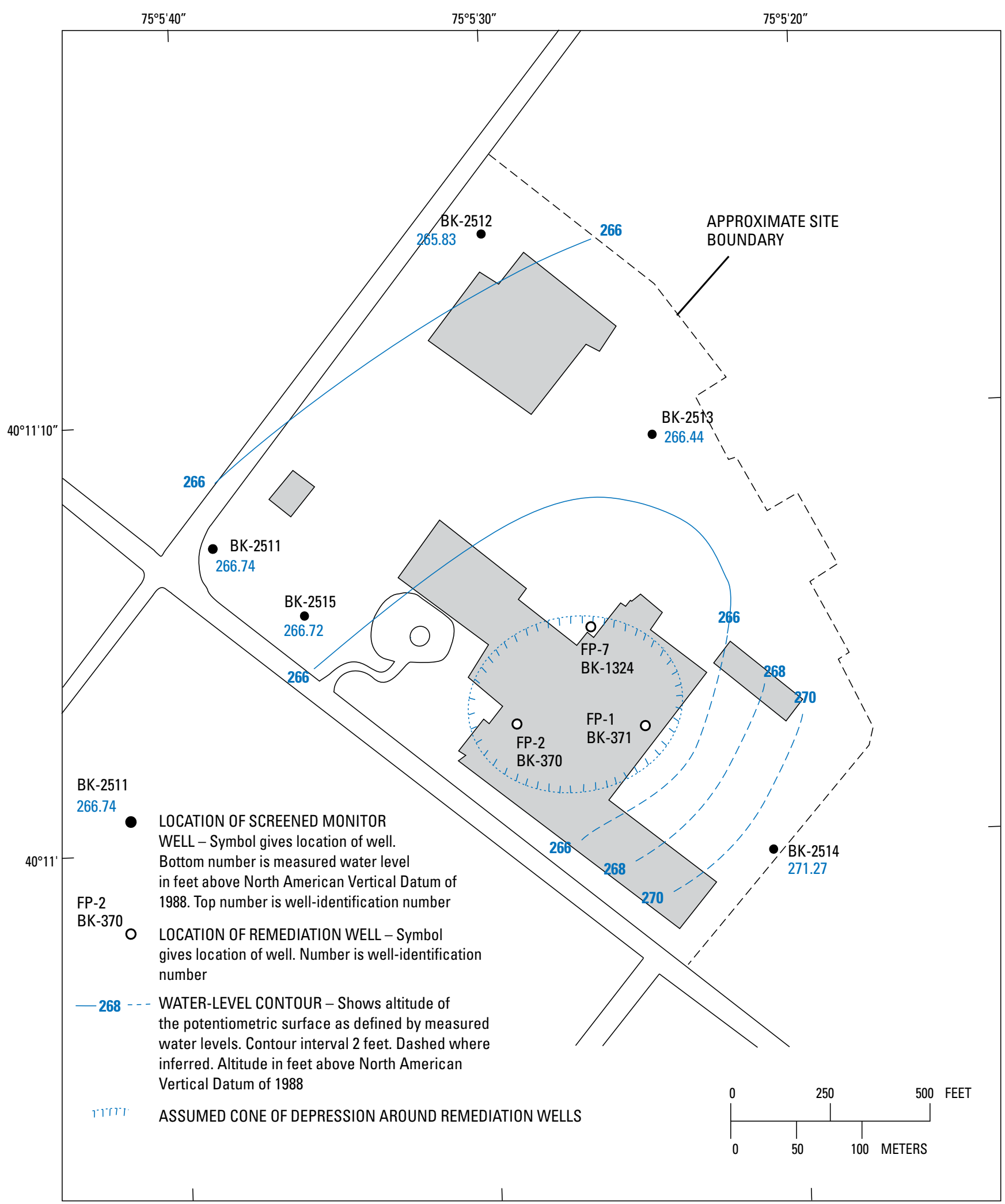

Base from U.S. Geological Survey digital data,1972, 1:2,000,000 Albers Equal-Area Conic Projection.

Standard parallels $29^{\circ} 30^{\prime} \mathrm{N}$, central meridian $75^{\circ} 00^{\prime} \mathrm{W}$.

Figure 19. Potentiometric surface measured in wells screened in the deep zone at the Fischer and Porter Superfund Site, Warminster Township, Bucks County, Pennsylvania, September 15, 2006. 


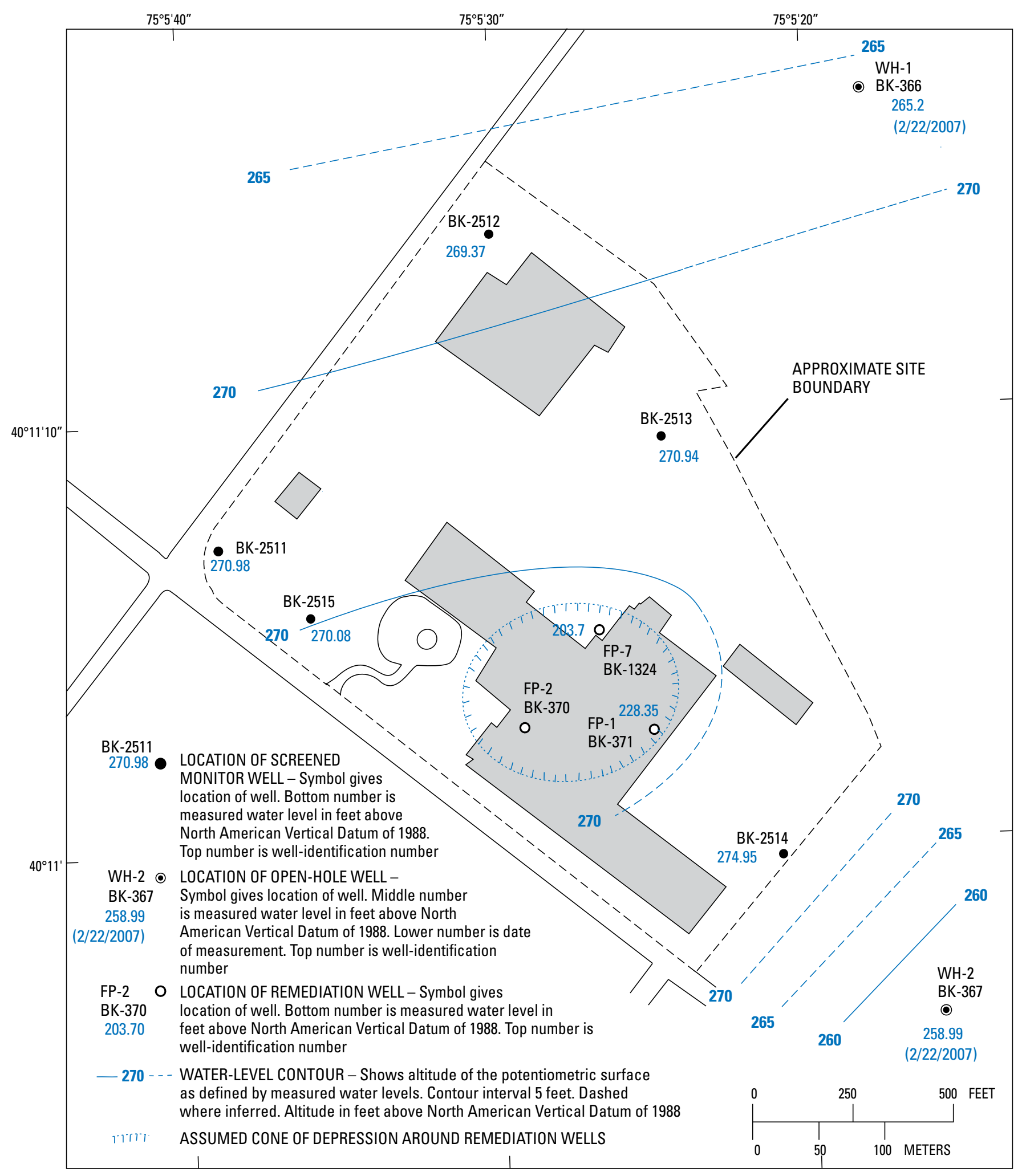

Base from U.S. Geological Survey digital data,1972, 1:2,000,000 Albers Equal-Area Conic Projection.

Standard parallels $29^{\circ} 30^{\prime} \mathrm{N}$, central meridian $75^{\circ} 00^{\prime} \mathrm{W}$.

Figure 20. Potentiometric surface measured in wells screened in the deep zone at the Fischer and Porter Superfund Site, Warminster Township, Bucks County, Pennsylvania, January 16-20, 2007. 


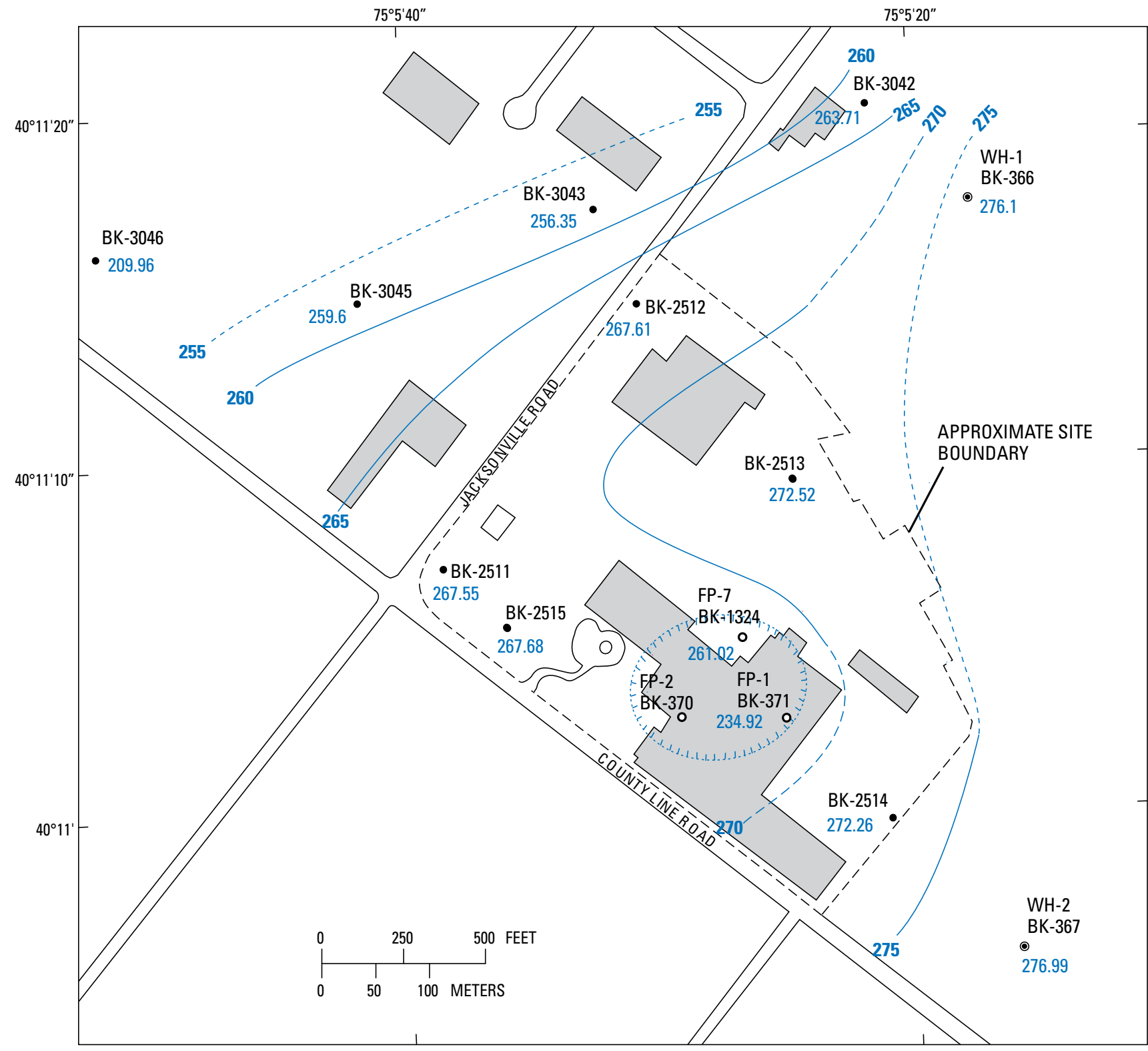

Base from U.S. Geological Survey digital data, 1972, 1:2,000,000 Albers Equal-Area Conic Projection.

Standard parallels $29^{\circ} 30^{\prime} \mathrm{N}$, central meridian $75^{\circ} 00^{\prime} \mathrm{W}$.

EXPLANATION

BK-2511

267.55

- LOCATION OF SCREENED MONITOR WELL Symbol gives location of well. Bottom number is measured water level in feet above North American Vertical Datum of 1988. Top number is

WH-2 well-identification number

BK-367 ๑ LOCATION OF OPEN-HOLE MONITOR

276.99 WELL - Symbol gives location of well. Bottom number is measured water level in feet above North American Vertical Datum of 1988. Top number is well-identification number
FP-2

BK-370

O LOCATION OF EXTRACTION WELL- Symbol gives location of well. Bottom number is measured water level in feet above North American Vertical Datum of 1988. Top number is well-identific ation number

- 270 - - WATER-LEVEL CONTOUR--Shows altitude of the potentiometric surface as defined by measured water levels. Contour interval 5 feet. Dashed where inferred. Altitude in feet above North American Vertical Datum of 1988

ASSUMED CONE OF DEPRESSION AROUND REMEDIATION WELLS

Figure 21. Potentiometric surface measured in wells screened in the deep zone at the Fischer and Porter Superfund Site, Warminster Township, Bucks County, Pennsylvania, May 21-22, 2009. 
gradient was 0.01. However, the difference in water-level altitude among three of the wells (BK-2511, BK-2512, and BK-2515) was only $0.13 \mathrm{ft}$.

The horizontal gradient on the northwestern side of the site was 0.010 in April 1996 (with the Warminster Heights wells and Fischer and Porter remediation wells FP-1 and FP-2 pumping), 0.009 in March 1996 (with the Warminster Heights wells pumping and the Fischer and Porter remediation wells not pumping), and 0.004 in December 1993 and May 1994 (with the Warminster Heights and the Fischer and Porter remediation wells pumping). In general, the horizontal hydraulic gradient on the northwestern side of the site has remained about the same.

\section{Vertical Groundwater Gradients}

Differences in water levels among the shallow, intermediate, and deep monitor wells at each monitor well cluster location indicate the presence of vertical head gradients. Measured heads (water-level elevations) were plotted on cross sections D-C, E-C, and D-E (locations of sections are shown on fig. 4). Along section D-C, the September 15, 2006, waterlevel measurements (fig. 22) showed a downward vertical hydraulic gradient from the shallow to the intermediate zone and an upward vertical hydraulic gradient from the deep to the intermediate zone (unit 3) at well clusters BK-1731-25212511 and BK-2528-2527-2515. An upward vertical gradient in stratigraphic unit 3 indicates groundwater flow through this unit toward the remediation wells. At well cluster BK-25262514 , the vertical head gradient was downward. The January 16-20, 2007, measurements showed an identical pattern. The measurements made on May 21-22, 2009 (fig. 23), show the same pattern except the vertical gradient was downward from stratigraphic unit 3 to stratigraphic unit 6 between wells BK-2521 and BK-2511.

Water levels were measured on December 13, 1993 (fig. 24), when the Warminster Heights and Fischer and Porter remediation wells were pumping and on December 15, 1993 (fig. 25), when the Warminster Heights wells were pumping and the Fischer and Porter remediation wells were not pumping (Sloto and others, 1996). When the Fisher and Porter remediation wells and Warminster Heights wells were pumping (fig. 24), the vertical head gradient was downward at all monitor well clusters. An upward vertical gradient in stratigraphic unit 3 indicates groundwater flows through this unit toward the remediation wells. On December 15, 1993, when the Warminster Heights wells were pumping and the Fisher and Porter remediation wells were not pumping (fig. 25), the vertical head gradient was downward at all monitor well clusters, and flow in stratigraphic unit 3 was away from the remediation wells.

Along section E-C, the September 15, 2006 (fig. 26), measurements showed an upward vertical hydraulic gradient at well cluster BK-2523-2522-2512 and a downward vertical hydraulic gradient at well cluster BK-2525-2524-2513. A groundwater divide (stagnation point) was present in the vicinity of well BK-2811, indicating that the pumping influence of the remediation wells did not reach well cluster BK-25252524-2513. At well cluster BK-2526-2514, the vertical head gradient was downward.

Along section E-C, the January 16-20, 2007 (fig. 27), water-level measurements showed a downward vertical hydraulic gradient from the shallow to the intermediate zone and an upward vertical hydraulic gradient from the deep to the intermediate zone at well cluster BK-2523-2522-2512. At well cluster BK-2525-2524-2513, the vertical hydraulic gradient was upward from the intermediate zone to the shallow zone and downward from the intermediate zone to the deep zone. A groundwater divide (stagnation point) was present in the vicinity of well BK-2811, indicating the pumping influence of the remediation wells did not reach well cluster BK-25252524-2513. At well cluster BK-2526-2514, the vertical head gradient was downward. This pattern is identical to the May 21-22, 2009, measurements.

Water levels were measured on December 13, 1993 (fig. 28), when the Warminster Heights and Fischer and Porter remediation wells were pumping (Sloto and others, 1996). The vertical hydraulic gradient was downward at well cluster BK-2523-2522-2512. At well cluster BK-2525-2524-2513, the vertical gradient was downward from the shallow zone to the intermediate zone, and the head was about the same in the deep and intermediate zones (the difference in head between the intermediate and deep zones was only $0.02 \mathrm{ft}$ ). A groundwater divide (stagnation point) was present between well BK-1324 and well cluster BK-2525-2524-2513, indicating the pumping influence of the remediation wells did not reach well cluster BK-2525-2524-2513. The vertical hydraulic gradient was downward from the shallow zone to the deep zone at well cluster BK-2526-2514.

Water levels were measured on December 15, 1993 (fig. 29), when the Warminster Heights wells were pumping and the Fischer and Porter remediation wells were not pumping (Sloto and others, 1996). On December 15, 1993, the vertical gradient was downward from the shallow zone to the intermediate zone and upward from the deep zone to the intermediate zone at well cluster BK-2525-2524-2513. At well cluster BK-2523-2522-2512, the vertical head gradient was upward from the intermediate zone to the shallow zone and downward from the intermediate zone to the deep zone; however, the difference in head was only $0.32 \mathrm{ft}$ between the shallow and intermediate zones and only $0.22 \mathrm{ft}$ between the intermediate and deep zones. The vertical hydraulic gradient was downward from the shallow zone to the deep zone at well cluster BK-2526-2514.

Section D-E is approximately along strike at the northeastern boundary of the Fischer and Porter Site. Water levels were measured on December 13, 1993 (fig. 30), when the Warminster Heights and Fischer and Porter remediation wells were pumping and on December 15, 1993, when the Warminster Heights wells were pumping and the Fischer and Porter remediation wells were not pumping (Sloto and 


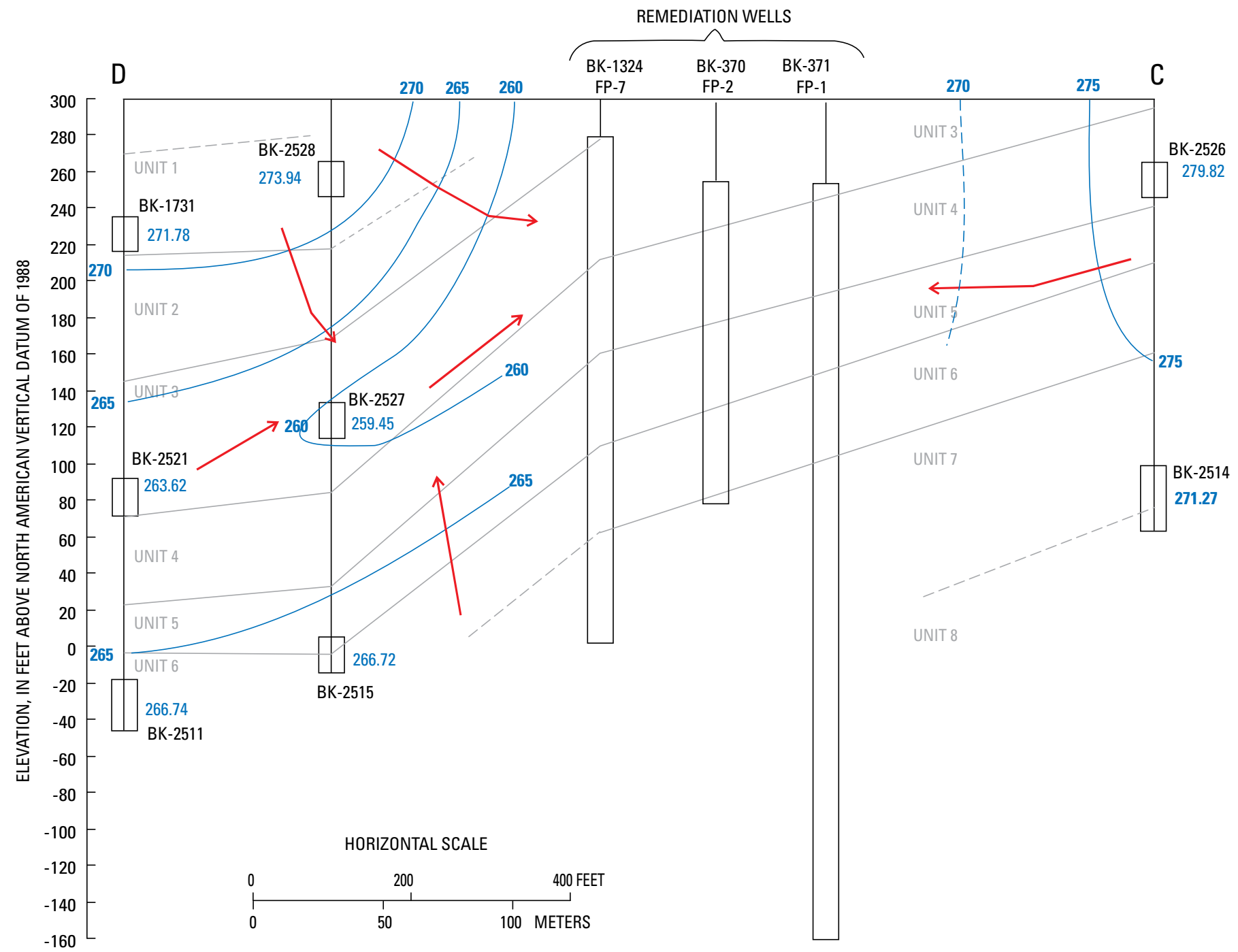

\section{EXPLANATION}
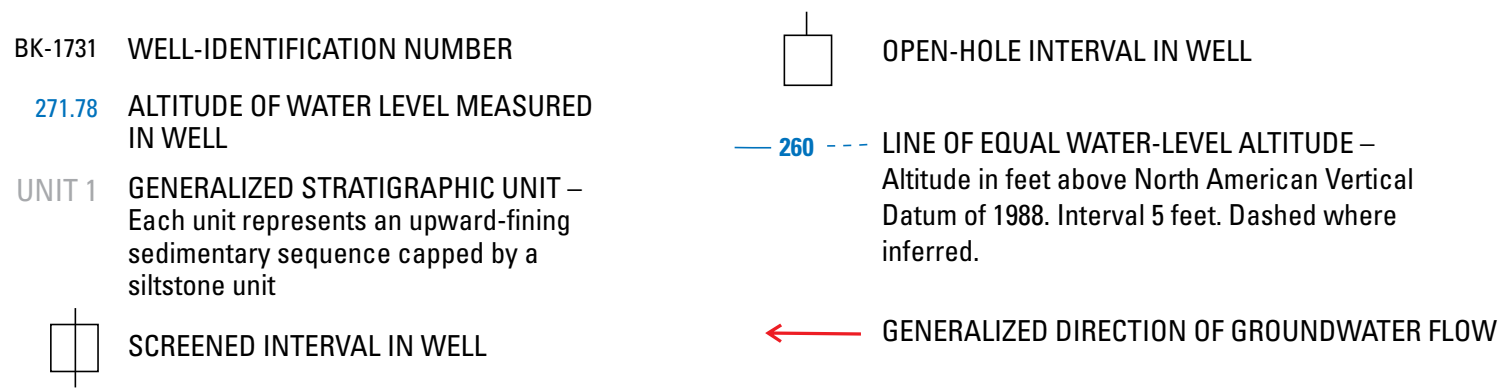

Figure 22. Water-level altitude and direction of groundwater flow along section D-C, Fischer and Porter Superfund Site, Warminster Township, Bucks County, Pennsylvania, September 15, 2006. Wells BK-370 and BK-371 are projected to line of section. The location of section D-C is shown on figure 4. 


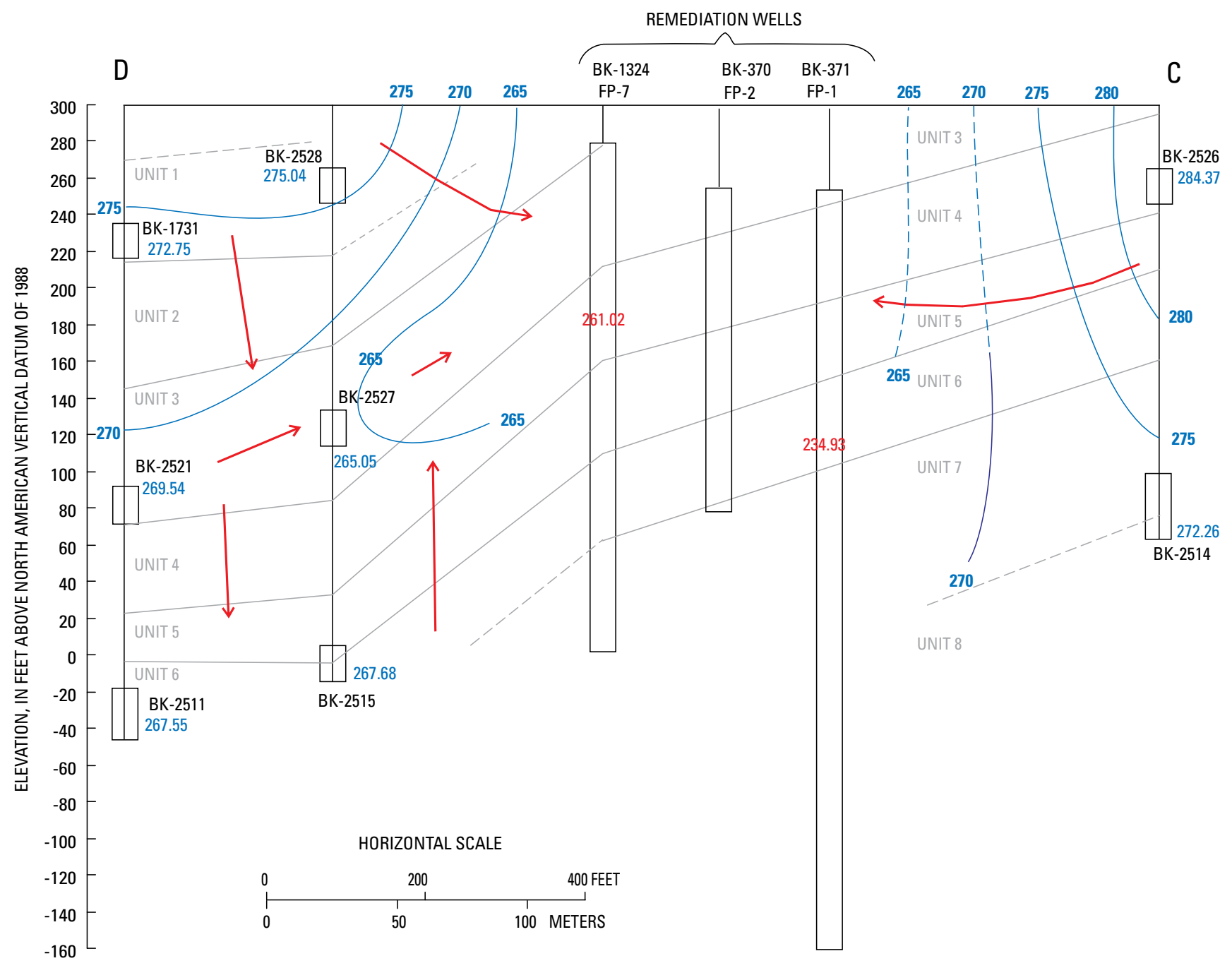

EXPLANATION
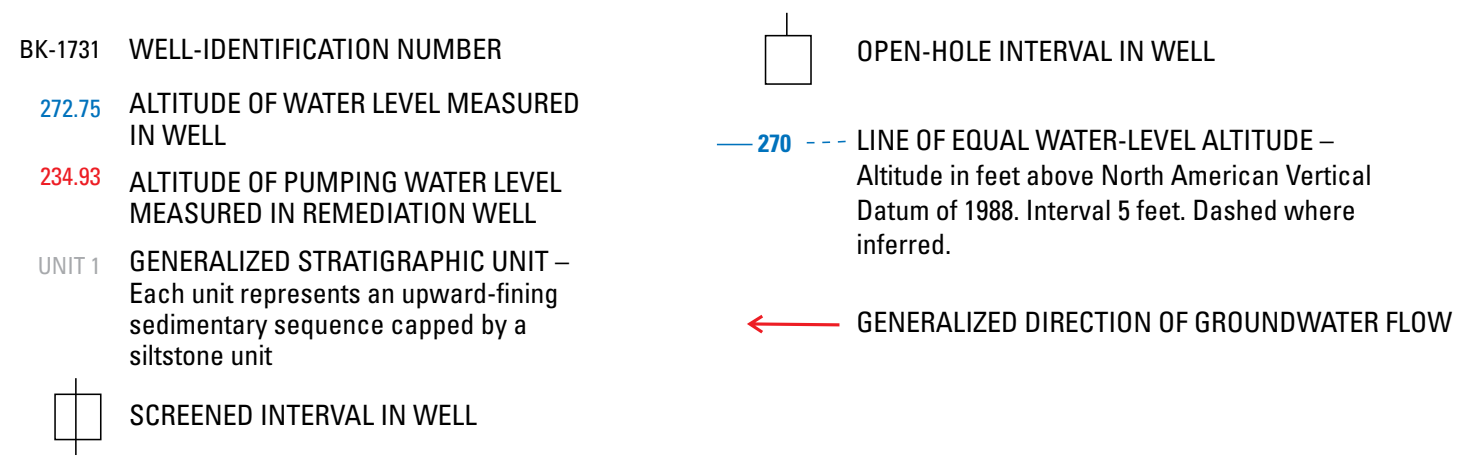

Figure 23. Water-level altitude and direction of groundwater flow along section D-C, Fischer and Porter Superfund Site, Warminster Township, Bucks County, Pennsylvania, May 21-22, 2009. Wells BK-370 and BK-371 are projected to line of section. The location of section D-C is shown on figure 4. 


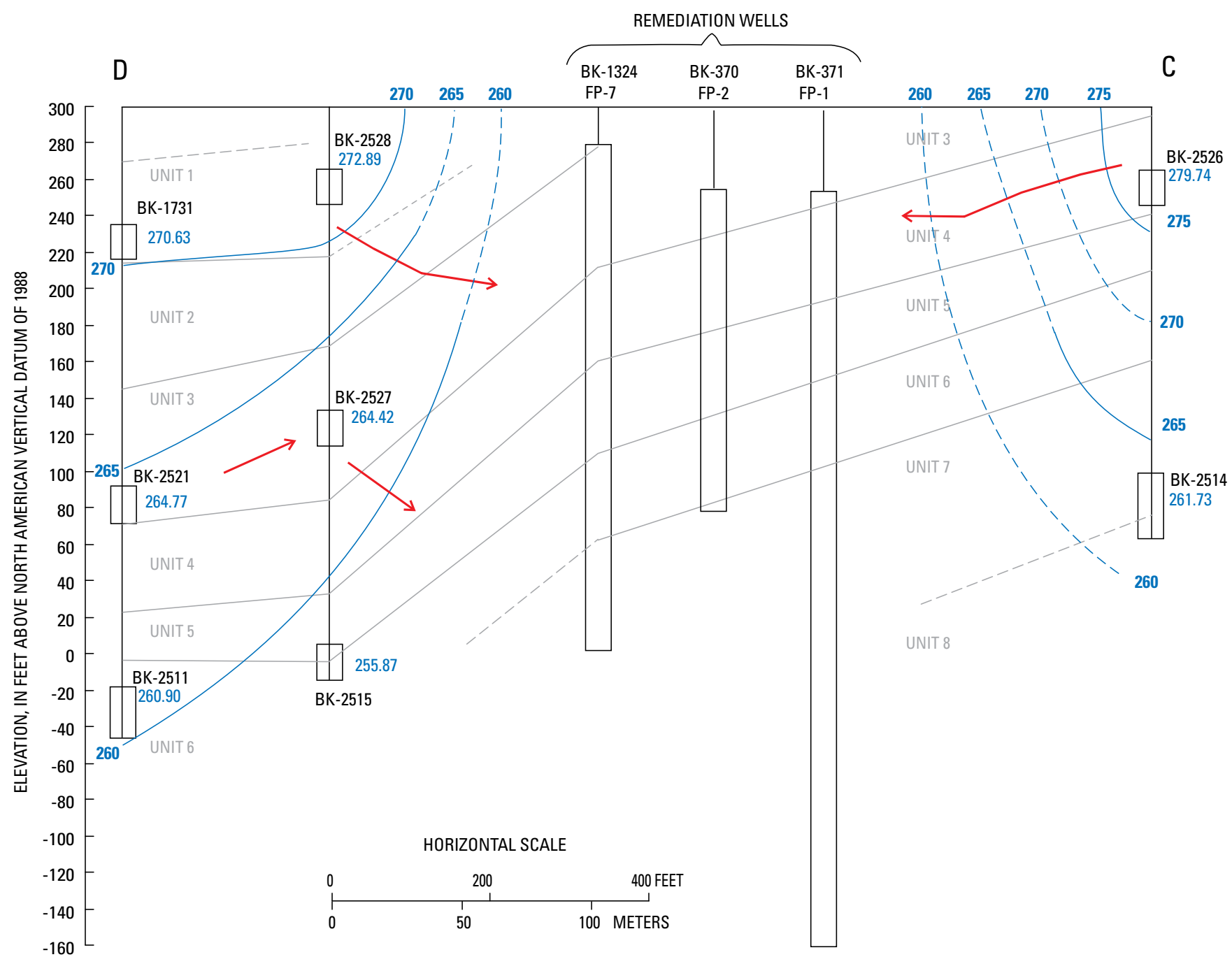

EXPLANATION
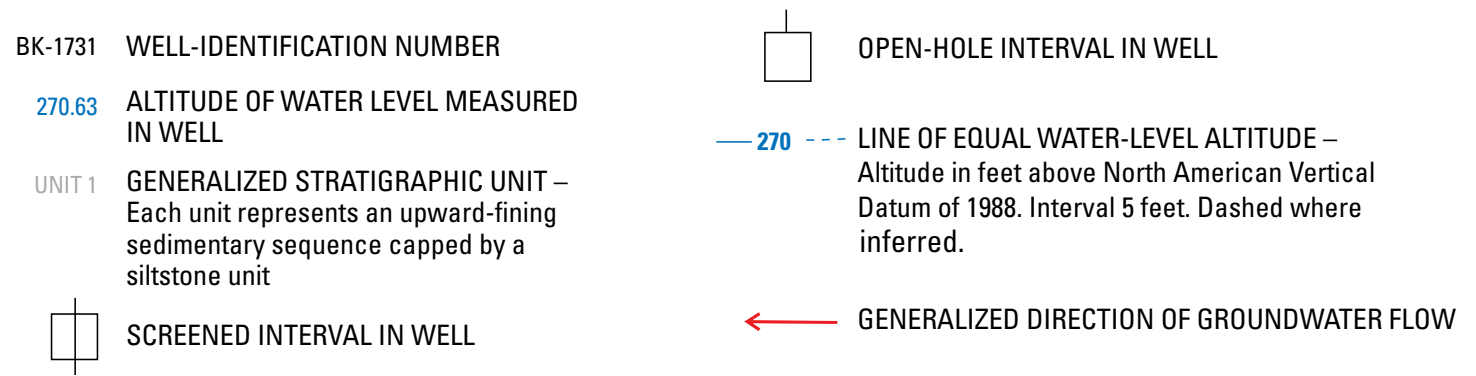

Figure 24. Water-level altitude and direction of groundwater flow along section D-C, Fischer and Porter Superfund Site, Warminster Township, Bucks County, Pennsylvania, December 13, 1993. Water-level data from Sloto and others (1996). Wells BK-370 and BK-371 are projected to line of section. The location of section D-C is shown on figure 4. 


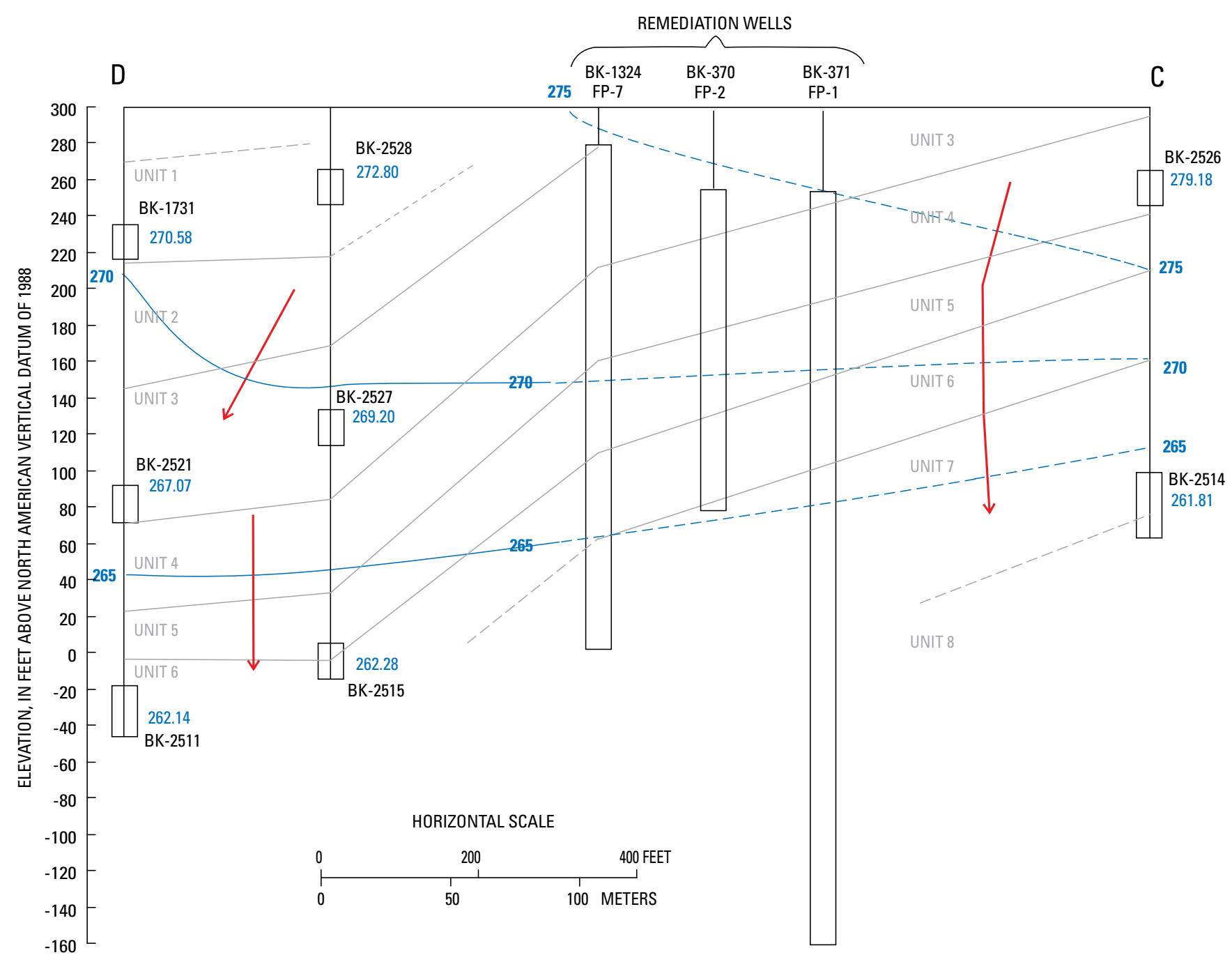

EXPLANATION
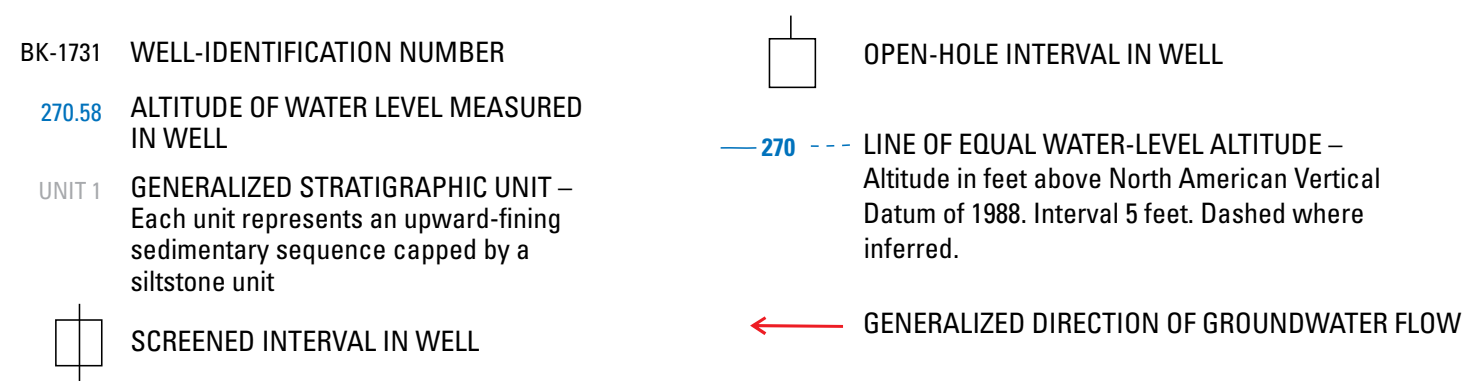

Figure 25. Water-level altitude and direction of groundwater flow along section D-C, Fischer and Porter Superfund Site, Warminster Township, Bucks County, Pennsylvania, December 15, 1993. Water-level data from Sloto and others (1996). Wells BK-370 and BK-371 are projected to line of section. The location of section D-C is shown on figure 4. 


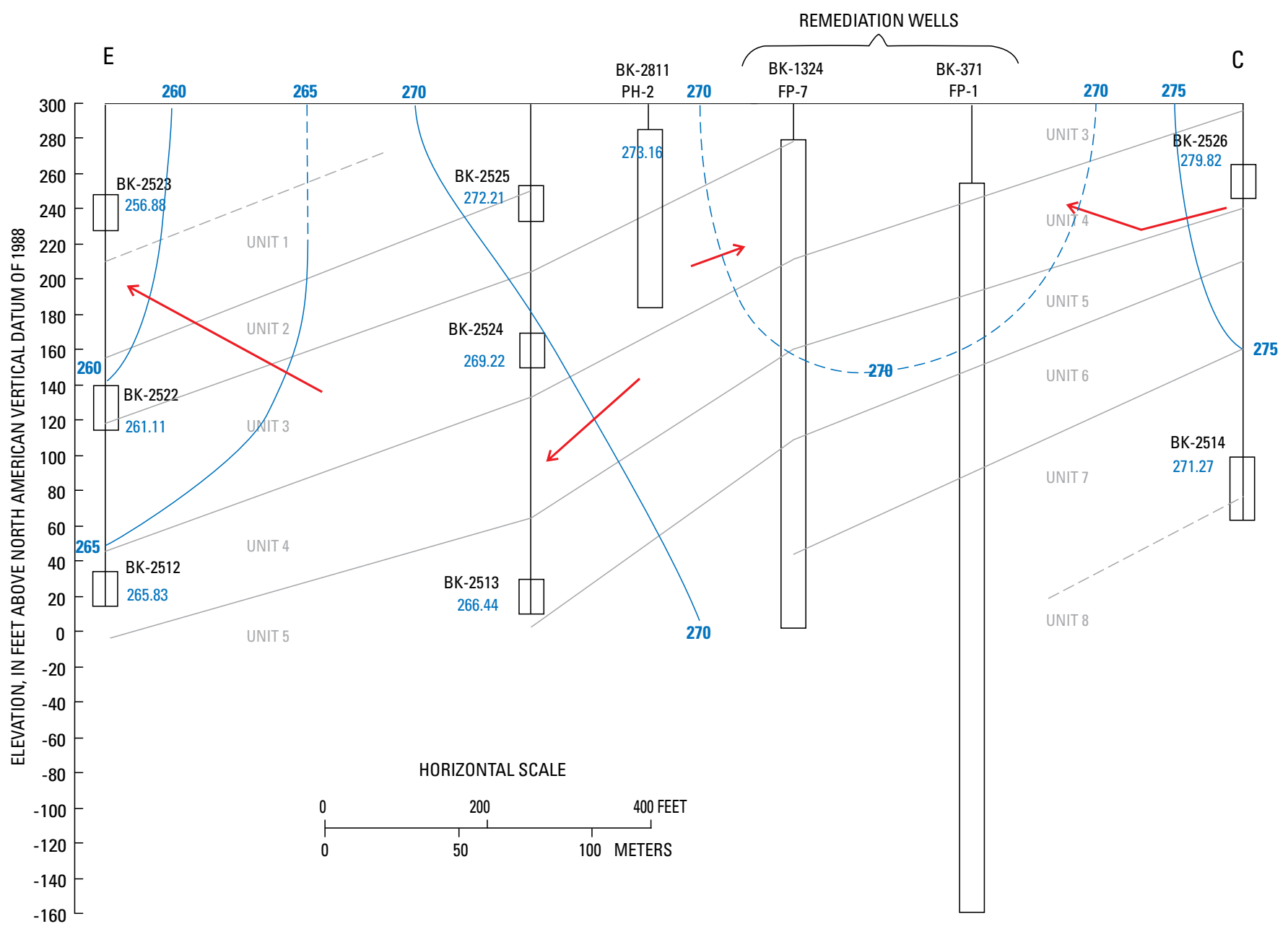

EXPLANATION
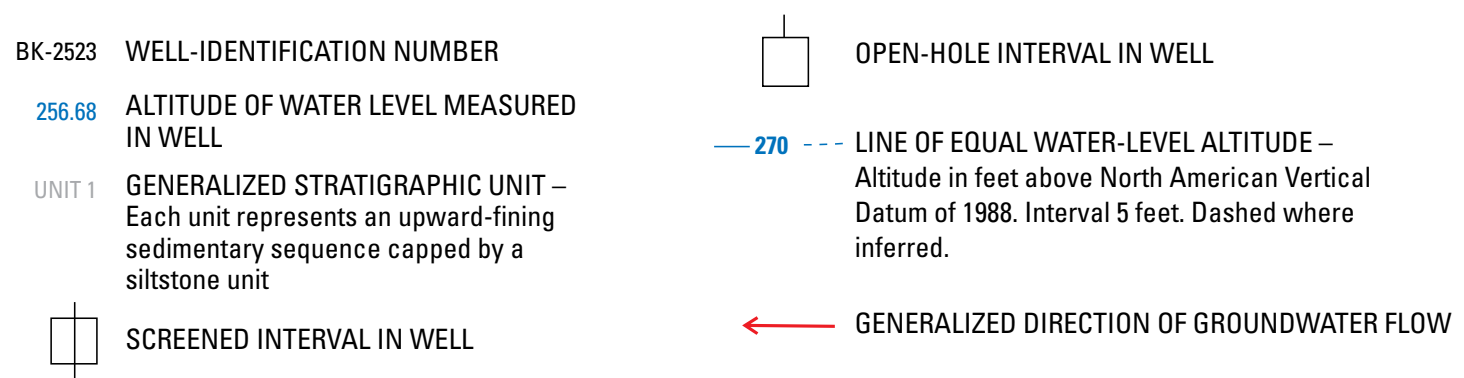

Figure 26. Water-level altitude and direction of groundwater flow along section E-C, Fischer and Porter Superfund Site, Warminster Township, Bucks County, Pennsylvania, September 15, 2006. Well BK-371 is projected to line of section. The location of section E-C is shown on figure 4. 


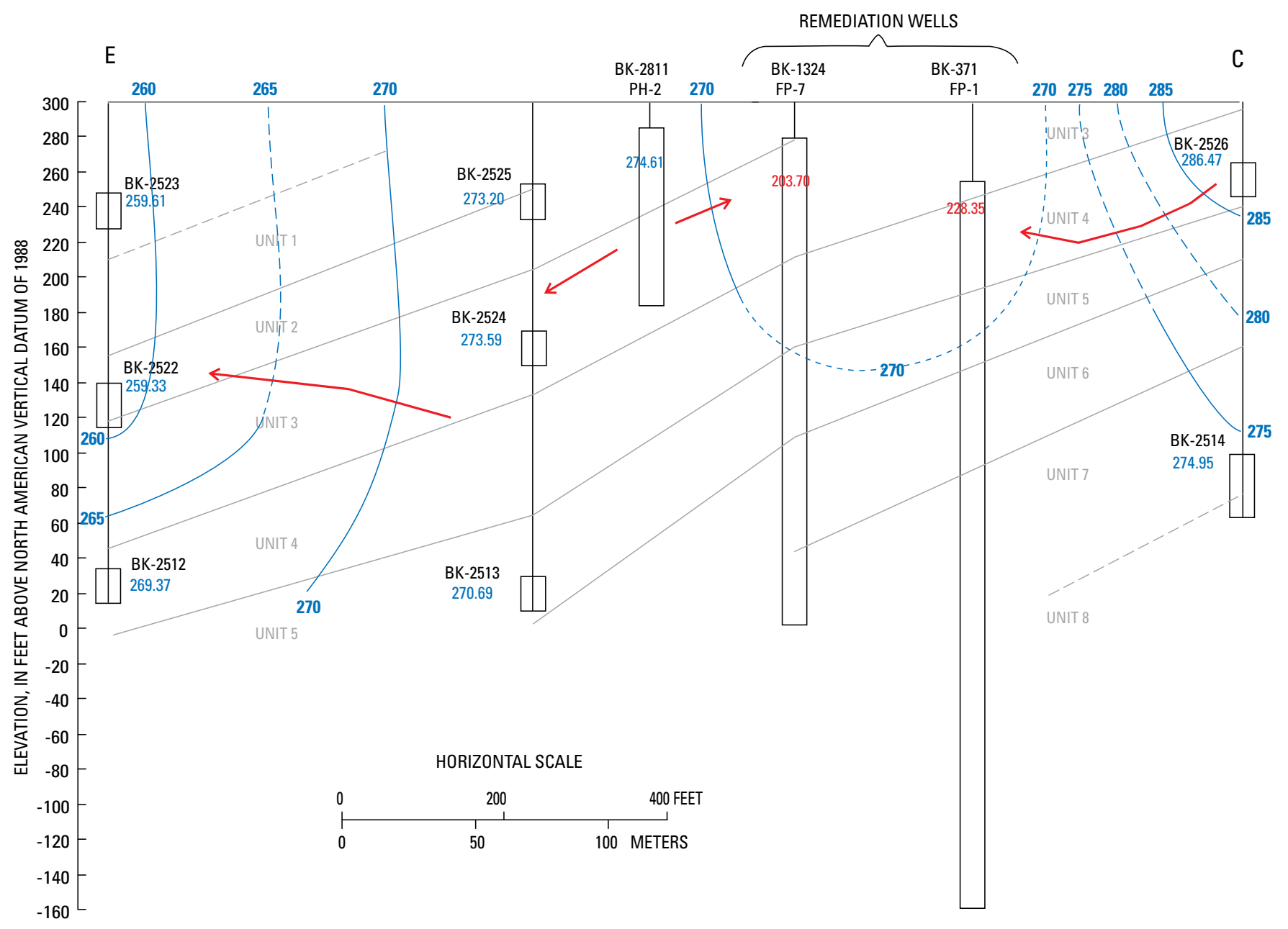

EXPLANATION
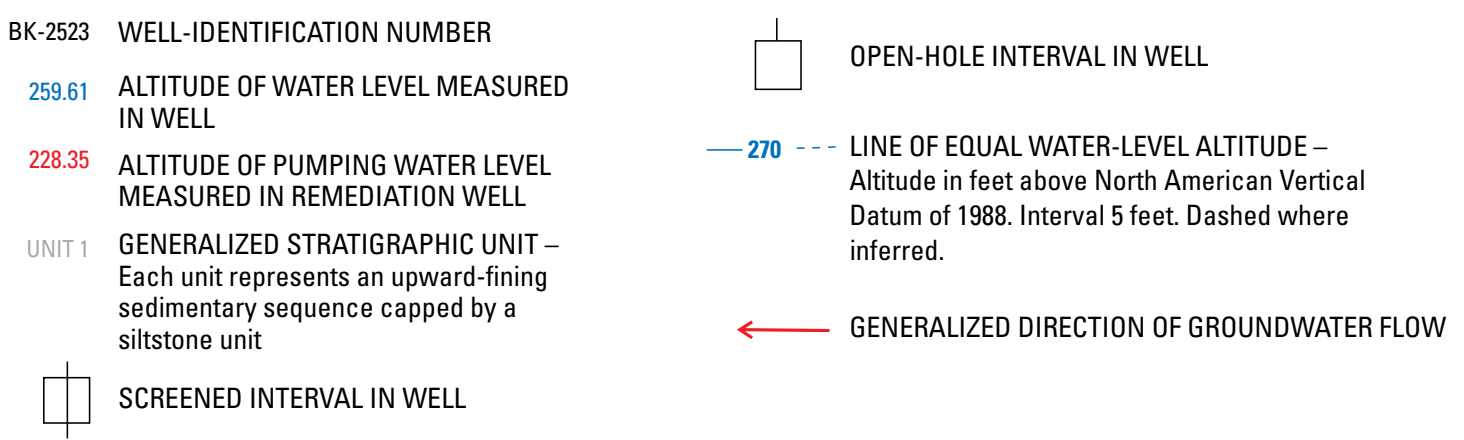

Figure 27. Water-level altitude and direction of groundwater flow along section E-C, Fischer and Porter Superfund Site, Warminster Township, Bucks County, Pennsylvania, January 16-20, 2007. Well BK-371 is projected to line of section. The location of section E-C is shown on figure 4. 


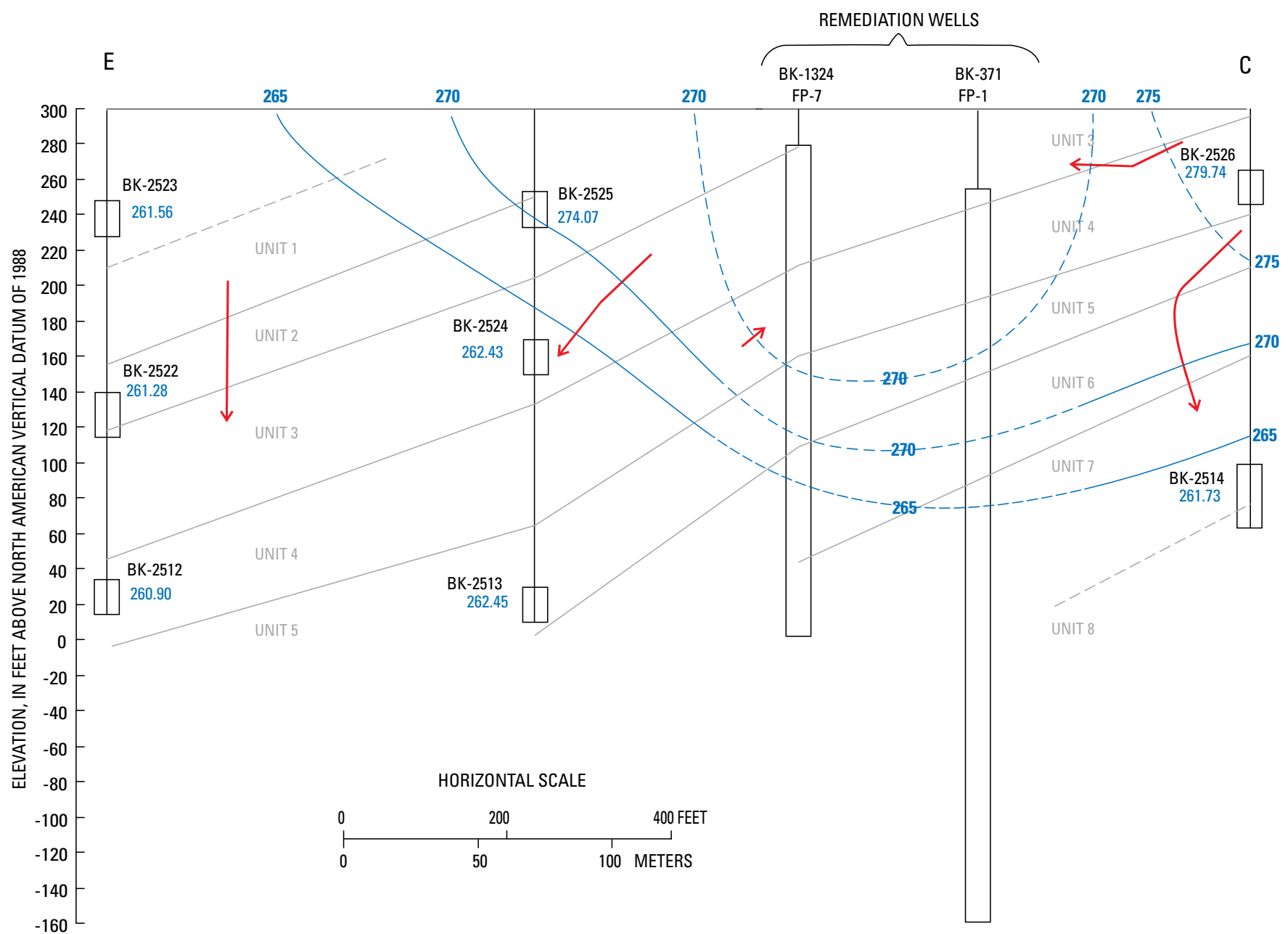

EXPLANATION

BK-2523 WELL-IDENTIFICATION NUMBER

261.56 ALTITUDE OF WATER LEVEL MEASURED IN WELL

UNIT 1 GENERALIZED STRATIGRAPHIC UNIT Each unit represents an upward-fining sedimentary sequence capped by a siltstone unit

$\square$ SCREENED INTERVAL IN WELL
OPEN-HOLE INTERVAL IN WELL

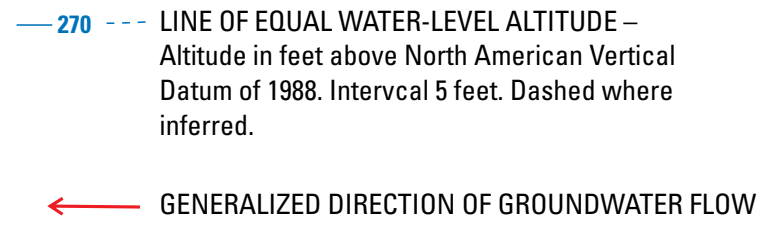

Figure 28. Water-level altitude and direction of groundwater flow along section E-C, Fischer and Porter Superfund Site, Warminster Township, Bucks County, Pennsylvania, December 13, 1993. Water-level data from Sloto and others (1996). Well BK-371 is projected to line of section. The location of section E-C is shown on figure 4. 


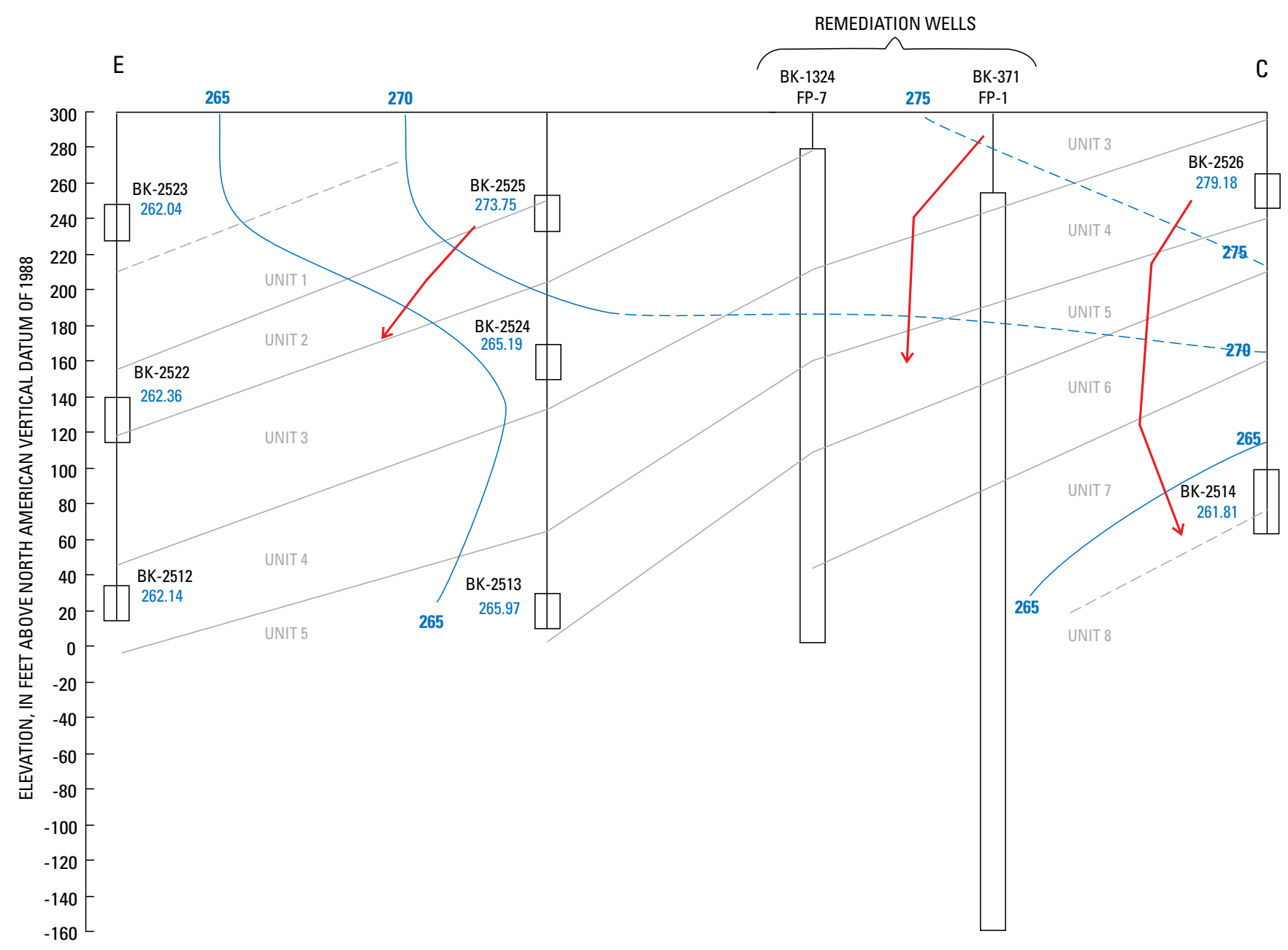

EXPLANATION
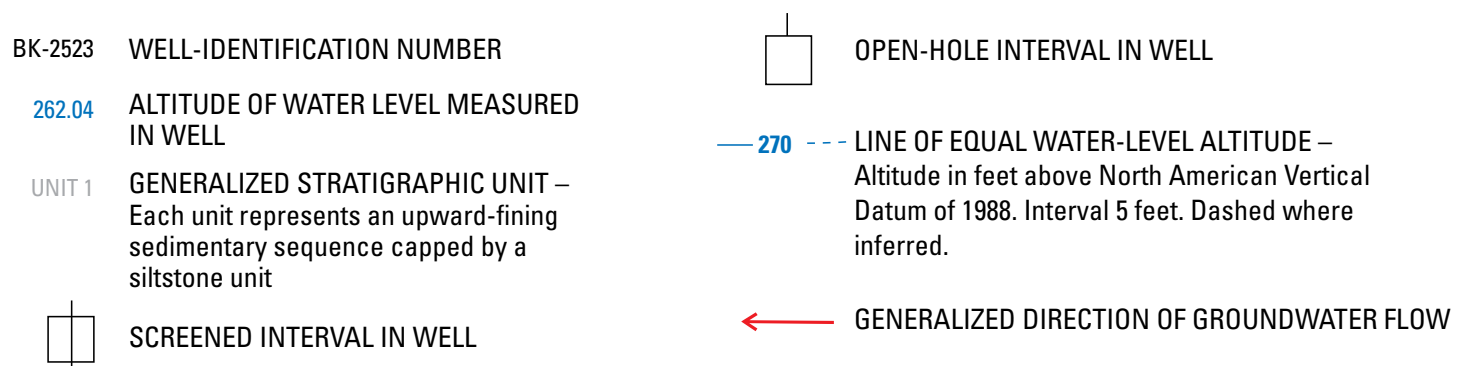

Figure 29. Water-level altitude and direction of groundwater flow along section E-C, Fischer and Porter Superfund Site, Warminster Township, Bucks County, Pennsylvania, December 15, 1993. Water-level data from Sloto and others (1996). Well BK-371 is projected to line of section. The location of section E-C is shown on figure 4. 
D

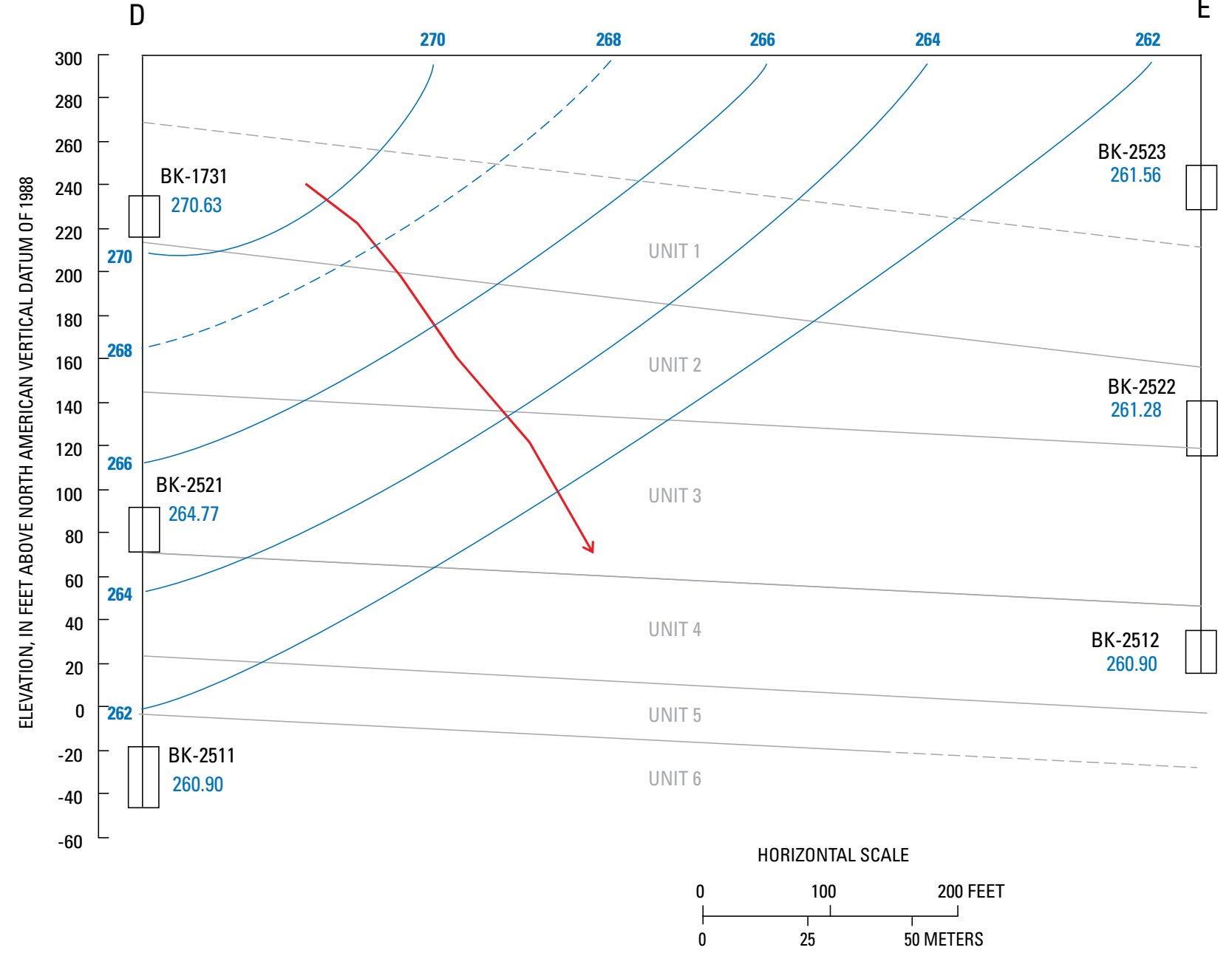

EXPLANATION

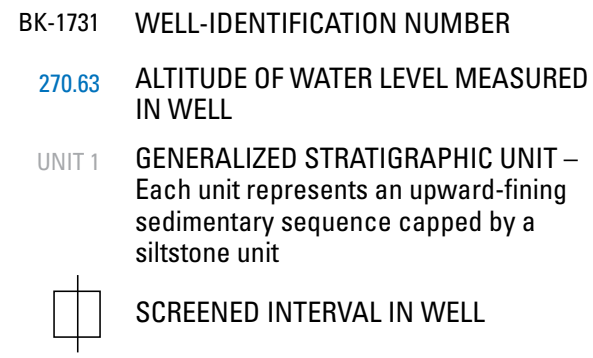
— 270 - - LINE OF EQUAL WATER-LEVEL ALTITUDE - Altitude in feet above North American Vertical Datum of 1988. Interval 2 feet. Dashed where inferred
$\longleftarrow$ GENERALIZED DIRECTION OF GROUNDWATER FLOW

Figure 30. Water-level altitude and direction of groundwater flow along section D-E, Fischer and Porter Superfund Site, Warminster Township, Bucks County, Pennsylvania, December 13, 1993. Water-level data from Sloto and others (1996). The location of section D-E is shown on figure 4 . 
others, 1996). For both dates, the groundwater-flow patterns were similar with groundwater flow from south to north and a downward vertical hydraulic gradient at both well clusters. Water levels measured on September 15, 2006, January 16-20, 2007 (fig. 31), and May 21-22, 2009, also showed groundwater flow from south to north; however, the vertical hydraulic gradient between the deep zone and the intermediate zone was upward instead of downward in 2006 and 2007.

\section{Changes in Volatile Organic Compound Concentration}

Water samples for laboratory analysis for VOCs were collected from the remediation and monitor wells at the Fischer and Porter Site by CH2M Hill, Inc. (1998) in 1996, TetraTech EM, Inc. (2005) in 2005, and for this study in 2007 and 2009. Results of laboratory analyses are presented in appendix 1. Compounds of concern for water samples collected in 200709 are summarized in table 5 .

A light non-aqueous phase liquid (LNAPL) was found in remediation well FP-7 by Sloto and others (1995, p. 17) and in a nearby core hole. During water-level measurements, $6.4 \mathrm{ft}$ of LNAPL was measured in well BK-2810 (PH-1) on September $15,2006,3.7 \mathrm{ft}$ was measured on January 19, 2007, and $3.4 \mathrm{ft}$ was measured on May 22, 2009. The LNAPL in well FP-7 was sampled by CH2M Hill, Inc. (1998) and was found to contain $520,000 \mu \mathrm{g} / \mathrm{kg}$ TCE and $65,000 \mu \mathrm{g} / \mathrm{kg}$ tetrachloroethylene (PCE). The LNAPL in well BK-2810 was sampled by TetraTech EM, Inc. (2005) and was found to contain an estimated concentration of $100,000 \mu \mathrm{g} / \mathrm{kg}$ of acetone; however, TCE and PCE were not reported as detected, and the detection limits were not given.

PCE and TCE can degrade into other organic compounds by anaerobic dehalogenation (fig. 32). The degradation of PCE produces TCE, and the degradation of TCE produces 1-1,dichloroethylene (1,1-DCE), cis-1,2-dichloroethylene (cis-1,2-DCE), trans-1,2-dichloroethylene (trans-1,2-DCE), and vinyl chloride. An organic compound is reduced if a reaction leads to an increase in its hydrogen content or a decrease in its oxygen content; however, reduction reactions are more precisely defined in terms of electron transfers. An organic compound is reduced if it undergoes a net gain of electrons as the result of a chemical reaction (electron acceptor) and is oxidized if it undergoes a net loss of electrons (electron donor). Under aerobic conditions, oxygen commonly acts as the electron acceptor when present. When oxygen is not present (anaerobic or anoxic conditions), microorganisms can use organic compounds or inorganic anions as alternate electron acceptors. Generally, organic compounds present at a contaminated site represent potential electron donors to support microbial metabolism. However, halogenated compounds can act as electron acceptors and thus become reduced in the reductive dehalogenation process. Dehalogenation by reduction is the replacement of a halogen, such as chloride, on an organic molecule by a hydrogen atom (fig. 32) (Sims and others, 1991).

In 2007, TCE concentrations measured in water samples taken from the three remediation wells by the USGS ranged from less than 340 to $3,000 \mu \mathrm{g} / \mathrm{L}$, and PCE concentrations ranged from less than 8.4 to $51 \mu \mathrm{g} / \mathrm{L}$. TCE concentrations in water samples from the source-area remediation wells have decreased with time but remain highly variable. The discharge lines from wells BK-370 (FP-2) and BK-371 (FP-1) are plumbed together; therefore, samples represent a combined water sample from both wells. From August 1997 to June 2001, the TCE and PCE concentrations in water samples from wells BK-370 and BK-371 showed an increasing trend, and from June 2001 to September 2008 showed a decreasing trend (figs. 33 and 34). TCE and PCE concentrations in water samples from well BK-1324 (FP-7) showed a decreasing trend (figs. 35 and 36).

\section{Horizontal Distribution of Volatile Organic Compounds}

In 2007, TCE concentrations measured in water samples from wells completed in the shallow zone ranged from less than 0.1 to $14,000 \mu \mathrm{g} / \mathrm{L}$ (fig. 37). The highest TCE concentration was in a water sample from well BK-2811 (PH-2), which is near the source area. The concentration of TCE in water samples from wells BK-2811 and BK-2827 (PH-4) for 1996-2007 was variable. The TCE plume extends off-site to the north of the source area (fig. 37). The plume followed the hydraulic gradient in the shallow zone (fig. 14). Concentrations of TCE in water samples from well BK-2525 east of the source area decreased from 1996 to 2007. Concentrations of TCE in water samples from well BK-2528 west of the source area increased from 1996 to 2007.

In 2007, PCE concentrations ranged from less than 0.1 to $340 \mu \mathrm{g} / \mathrm{L}$ (fig. 38). The highest PCE concentration was in a water sample from well BK-2811 (PH-2), which is near the source area; the PCE concentration in water samples from well BK-2811 for 1996-2007 was variable. The PCE plume extended off-site to the north of the source area (fig. 38). Concentrations of PCE in water samples from well BK-2827 east of the source area increased from 1996 to 2007.

In 2007, concentrations of degradation product cis-1,2-DCE ranged from less than 0.1 to $13,800 \mu \mathrm{g} / \mathrm{L}$ (fig. 39), and concentrations of degradation product trans-1,2-DCE ranged from less than 0.1 to $78 \mu \mathrm{g} / \mathrm{L}$ (fig. 39). Concentrations of cis-1,2-DCE were higher than concentrations of trans-1,2-DCE for all wells where the concentrations exceeded the detection limit. The highest concentrations of these compounds were in a water sample from well BK-2811 (PH-2), which is near the source area. These compounds were formed by the breakdown of TCE, and the plume had the same configuration as the TCE plume.

VOC concentrations in water samples from off-site monitor wells BK-3042, BK-3043, BK-3045, and BK-3046 were 
D

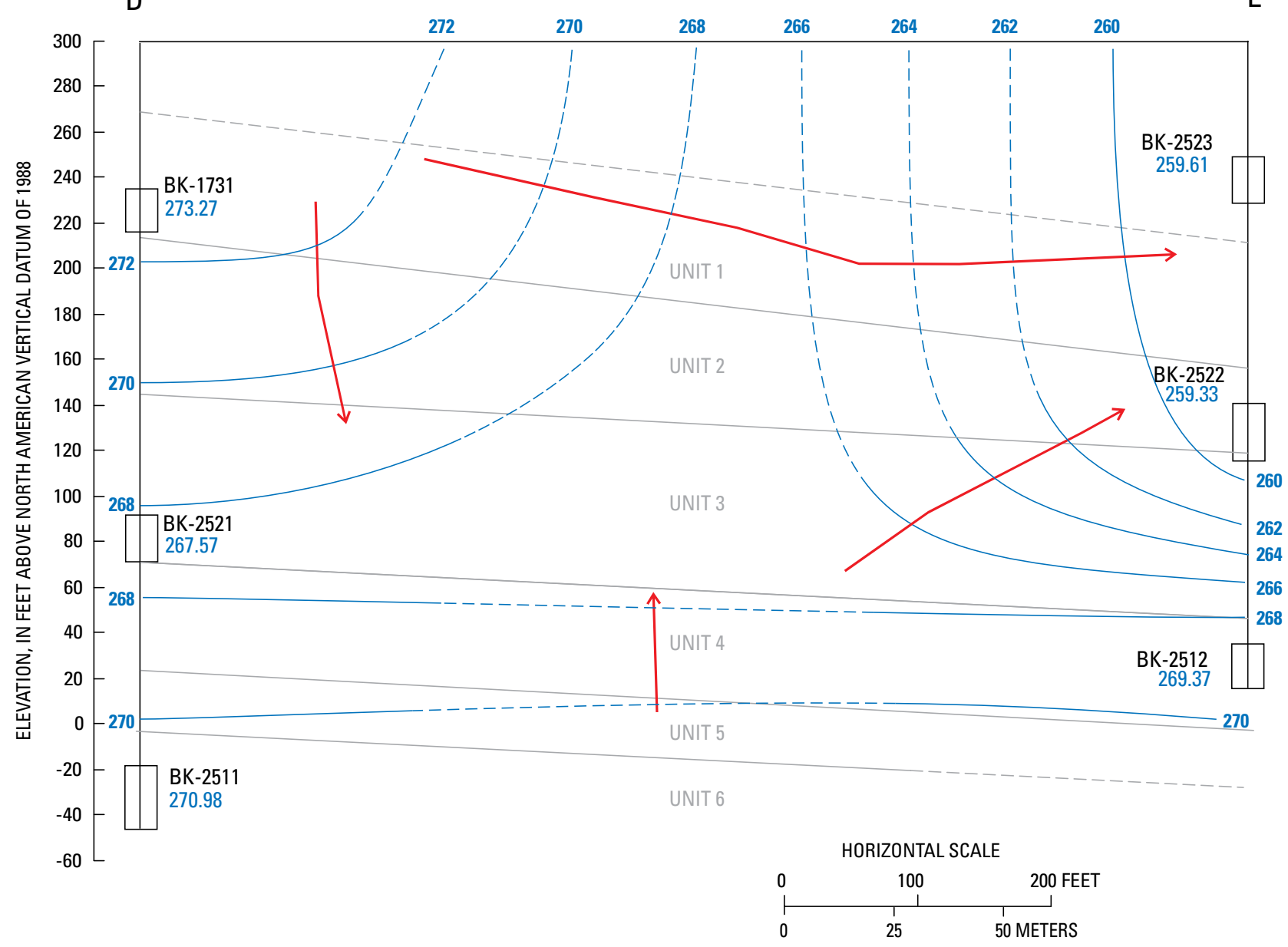

EXPLANATION

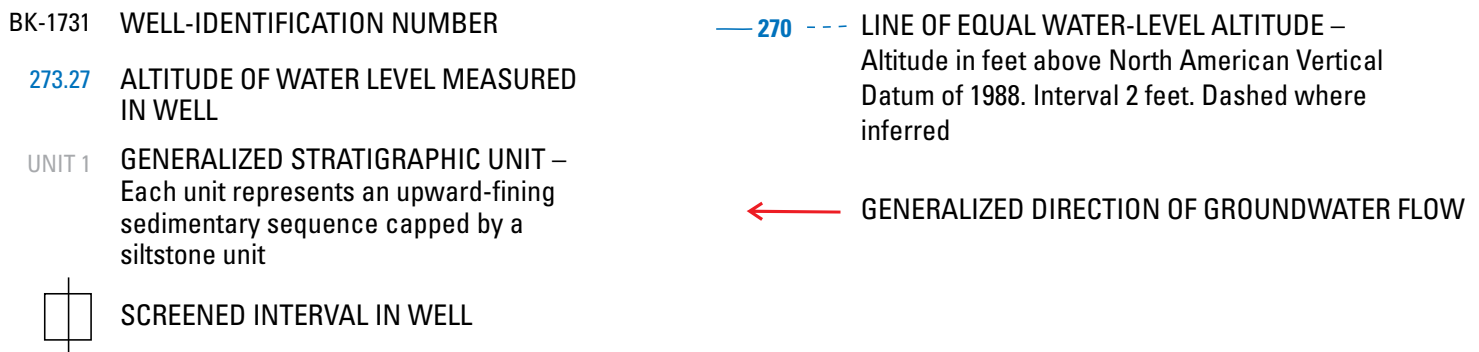

Figure 31. Water-level altitude and direction of groundwater flow along section D-E, Fischer and Porter Superfund Site, Warminster Township, Bucks County, Pennsylvania, January 16-20, 2007. The location of section D-E is shown on figure 4. 


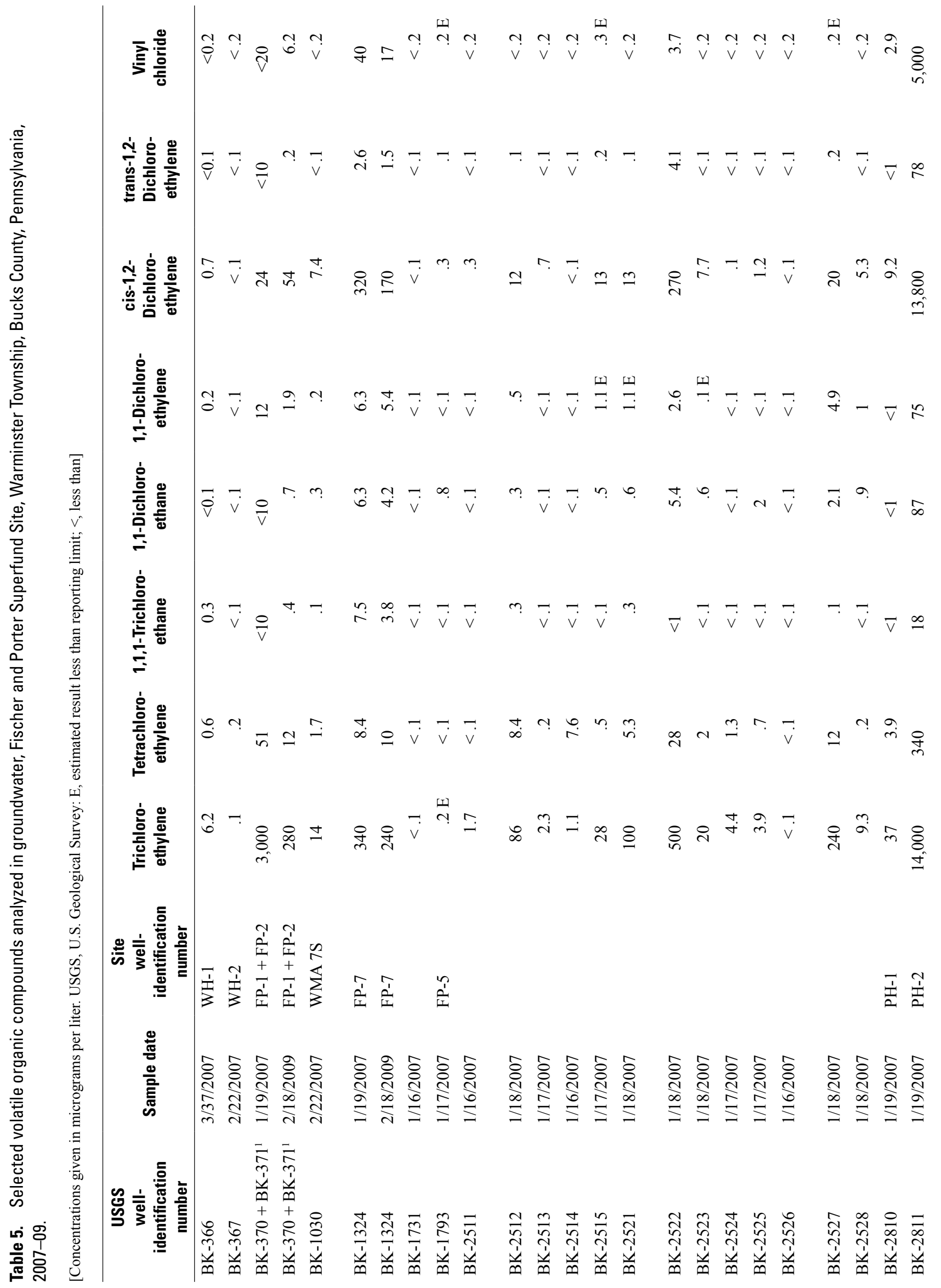




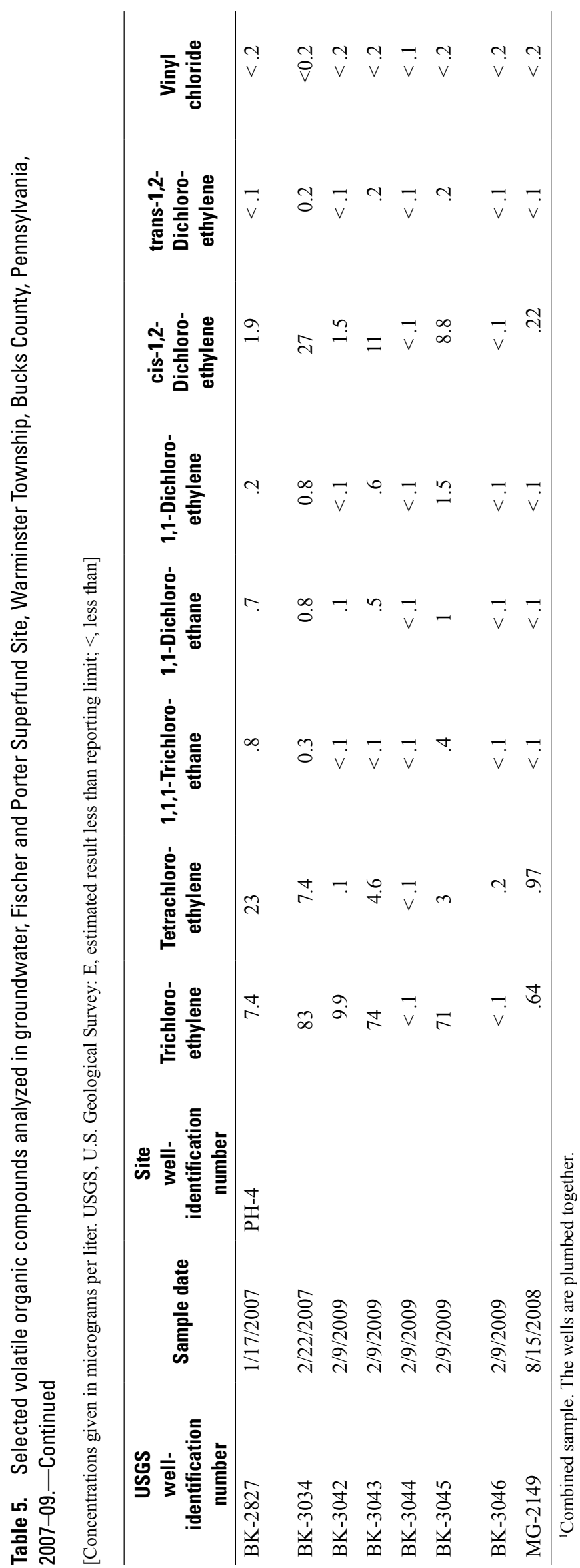




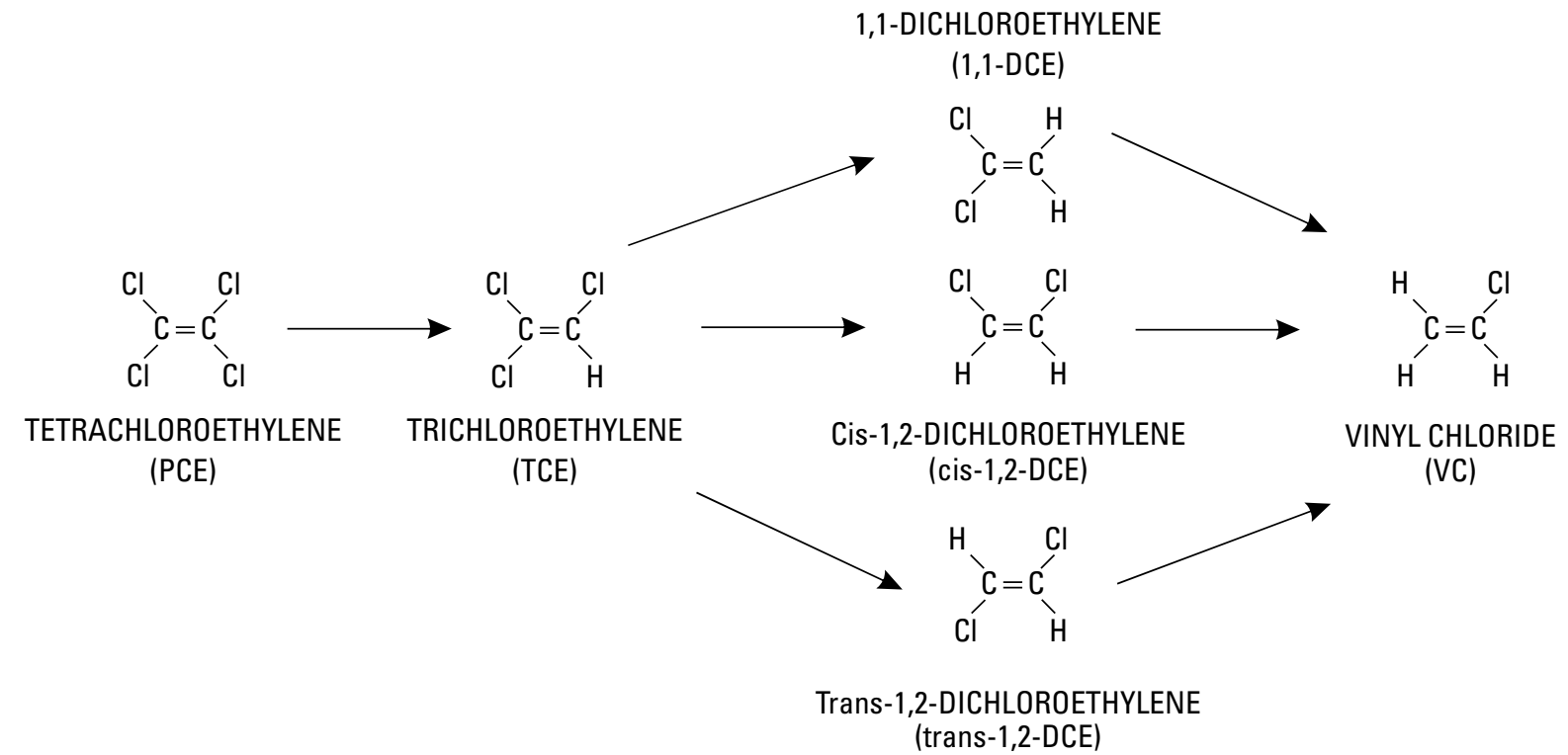

Figure 32. Typical reaction pathway for the anaerobic degradation of tetrachloroethylene and trichoroethylene by reductive dehalogenation.

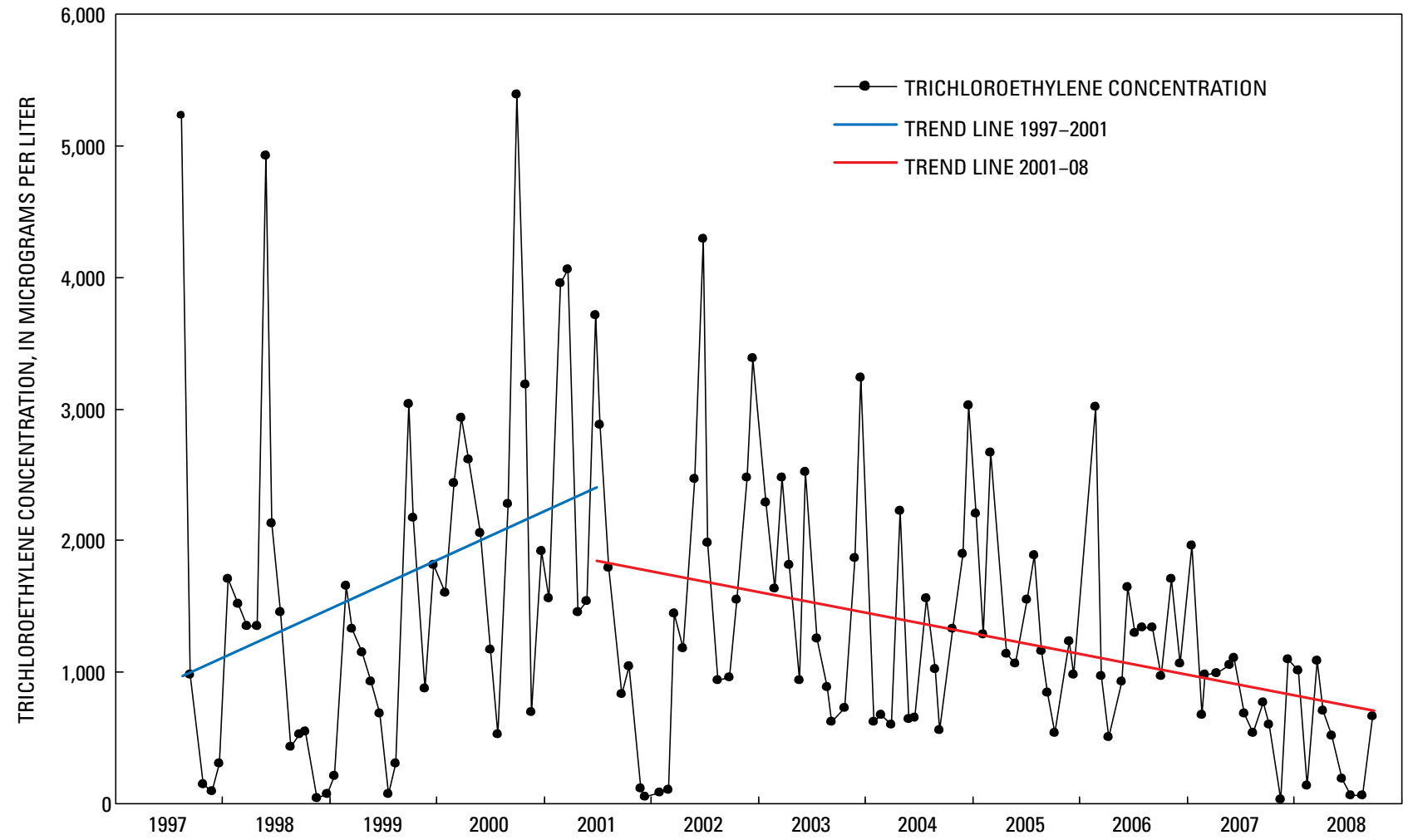

Figure 33. Concentration of trichloroethylene in monthly water samples from wells BK-370 and BK-371 (Fischer and Porter 1 and 2), Fischer and Porter Superfund Site, Warminster Township, Bucks County, Pennsylvania, 1997-2008. Data provided by $A B B$, Inc. 


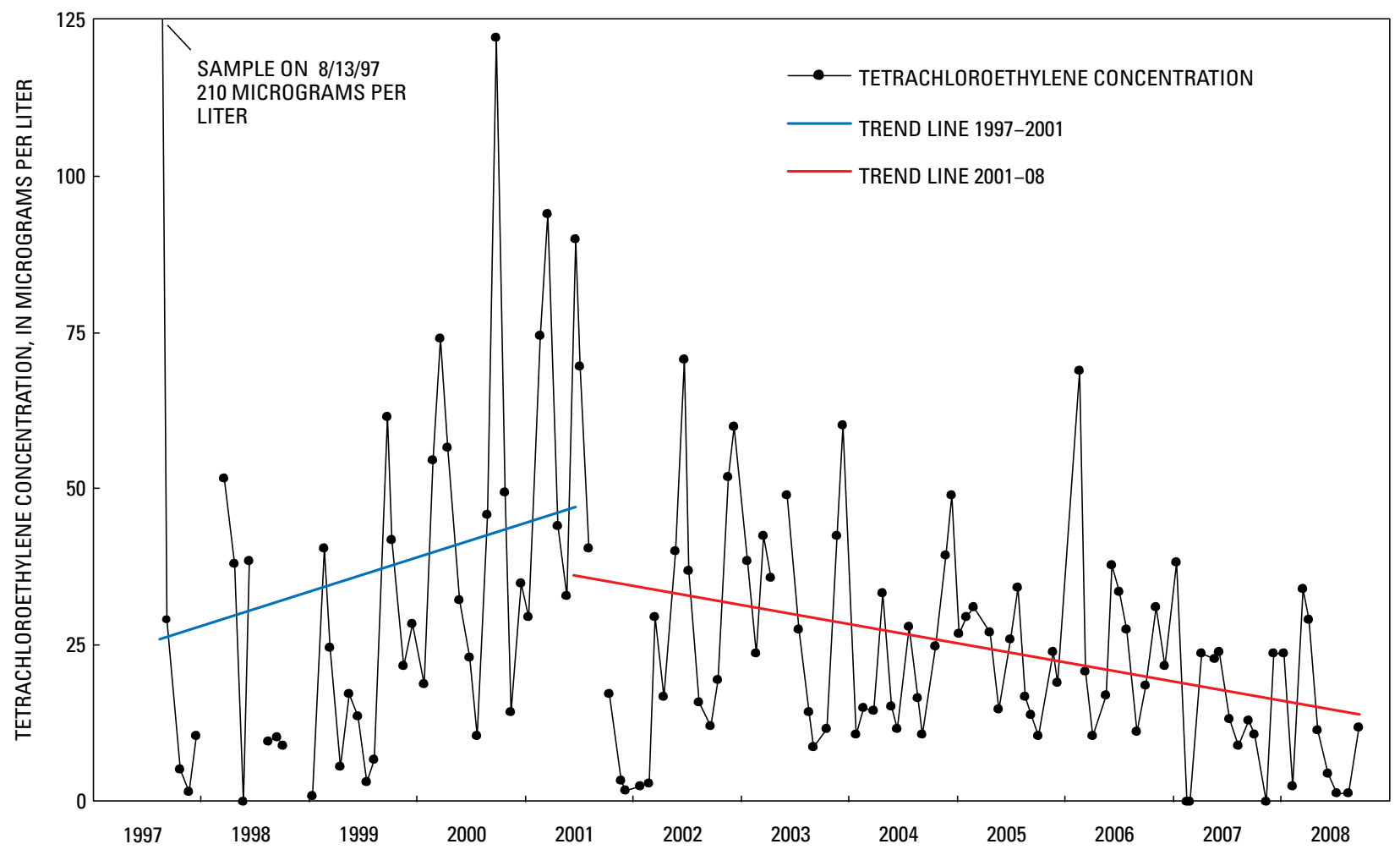

Figure 34. Concentration of tetrachloroethylene in monthly water samples from wells BK-370 and BK-371 (Fischer and Porter 1 and 2), Fischer and Porter Superfund Site, Warminster Township, Bucks County, Pennsylvania, 1997-2008. Data provided by ABB, Inc.

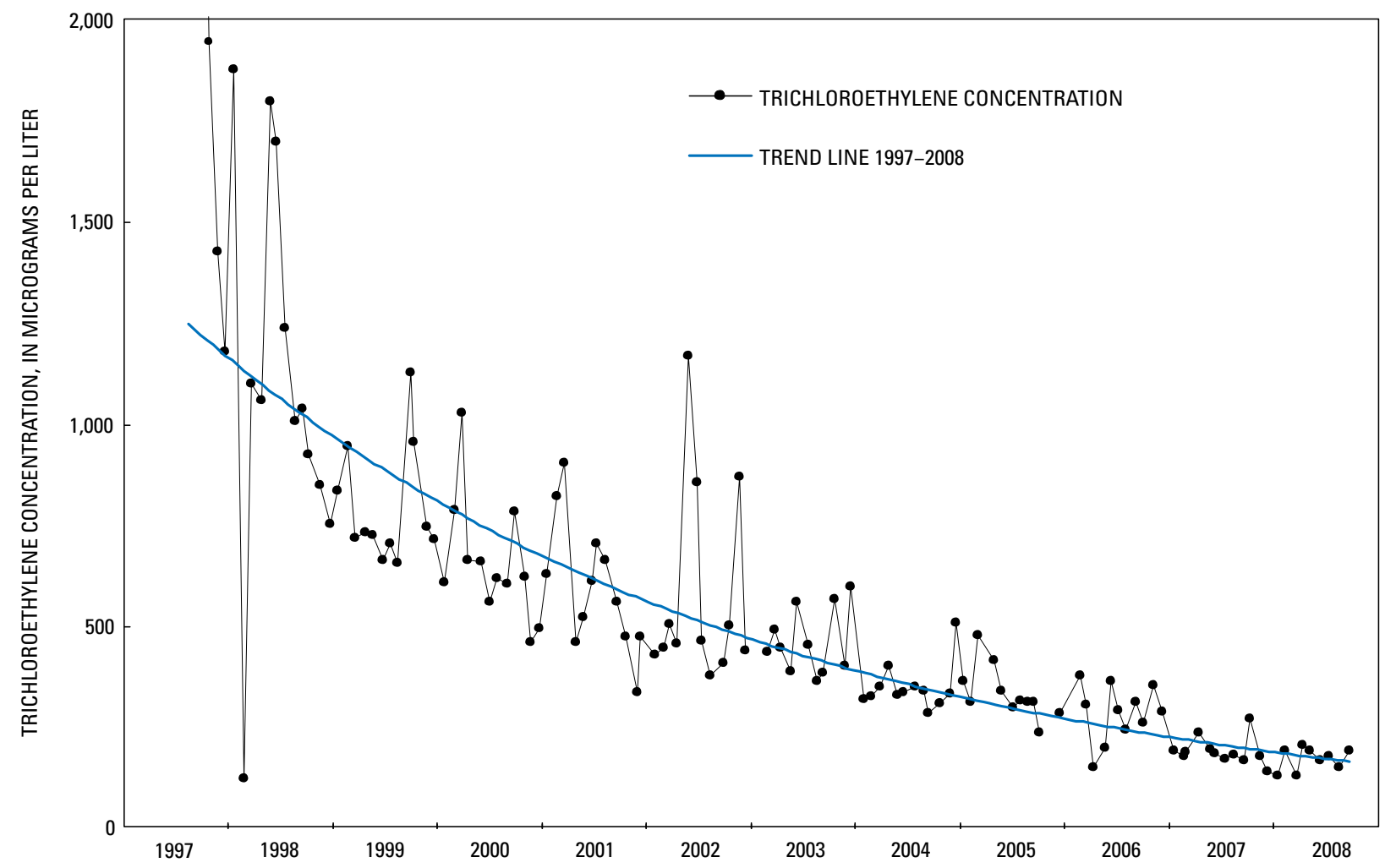

Figure 35. Concentration of trichloroethylene in monthly water samples from well BK-1324 (Fischer and Porter 7), Fischer and Porter Superfund Site, Warminster Township, Bucks County, Pennsylvania, 1997-2008. Data provided by ABB, Inc. 


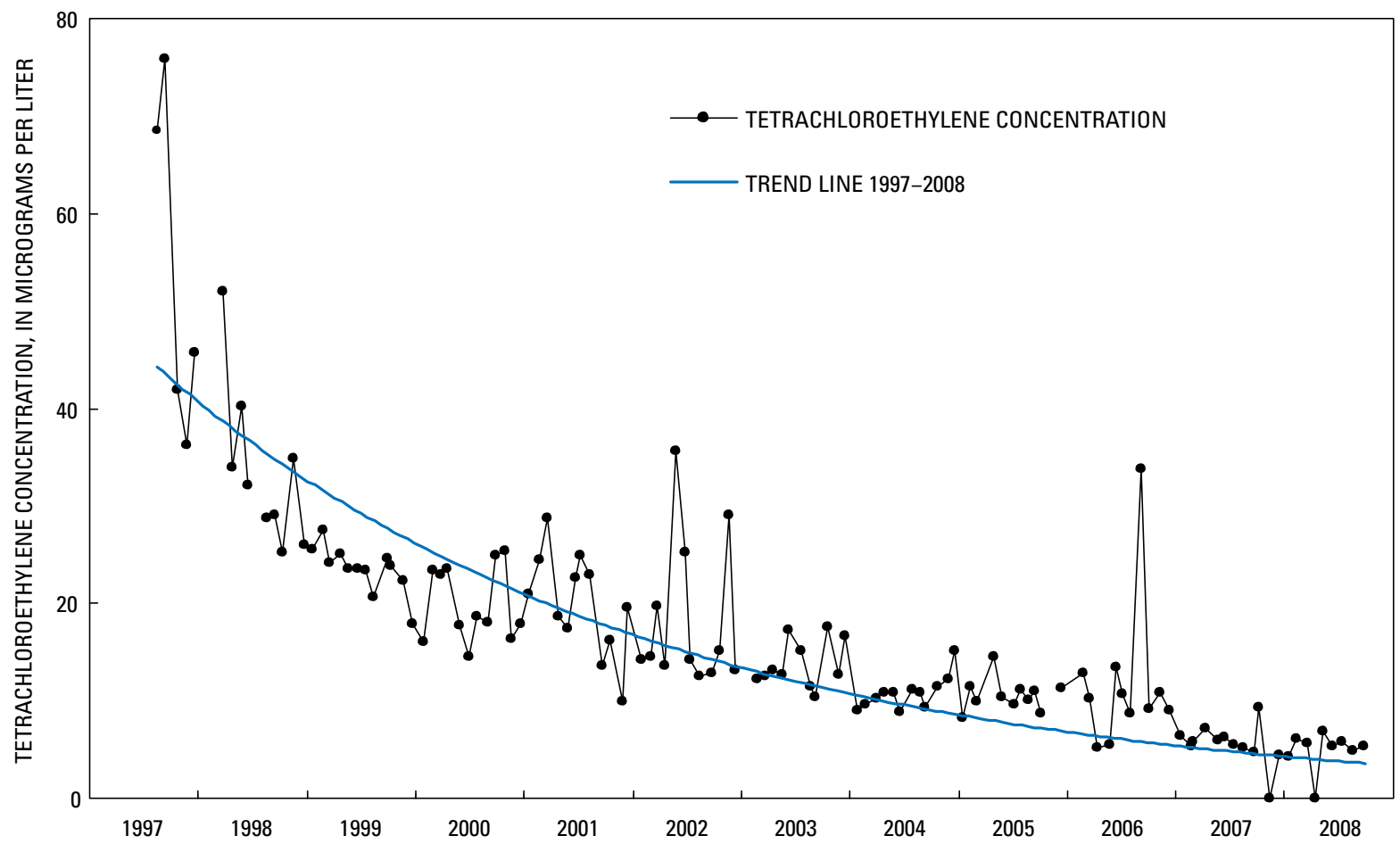

Figure 36. Concentration of tetrachloroethylene in monthly water samples from well BK-1324 (Fischer and Porter 7), Fischer and Porter Superfund Site, Warminster Township, Bucks County, Pennsylvania, 1997-2008. Data provided by $A B B$, Inc. 


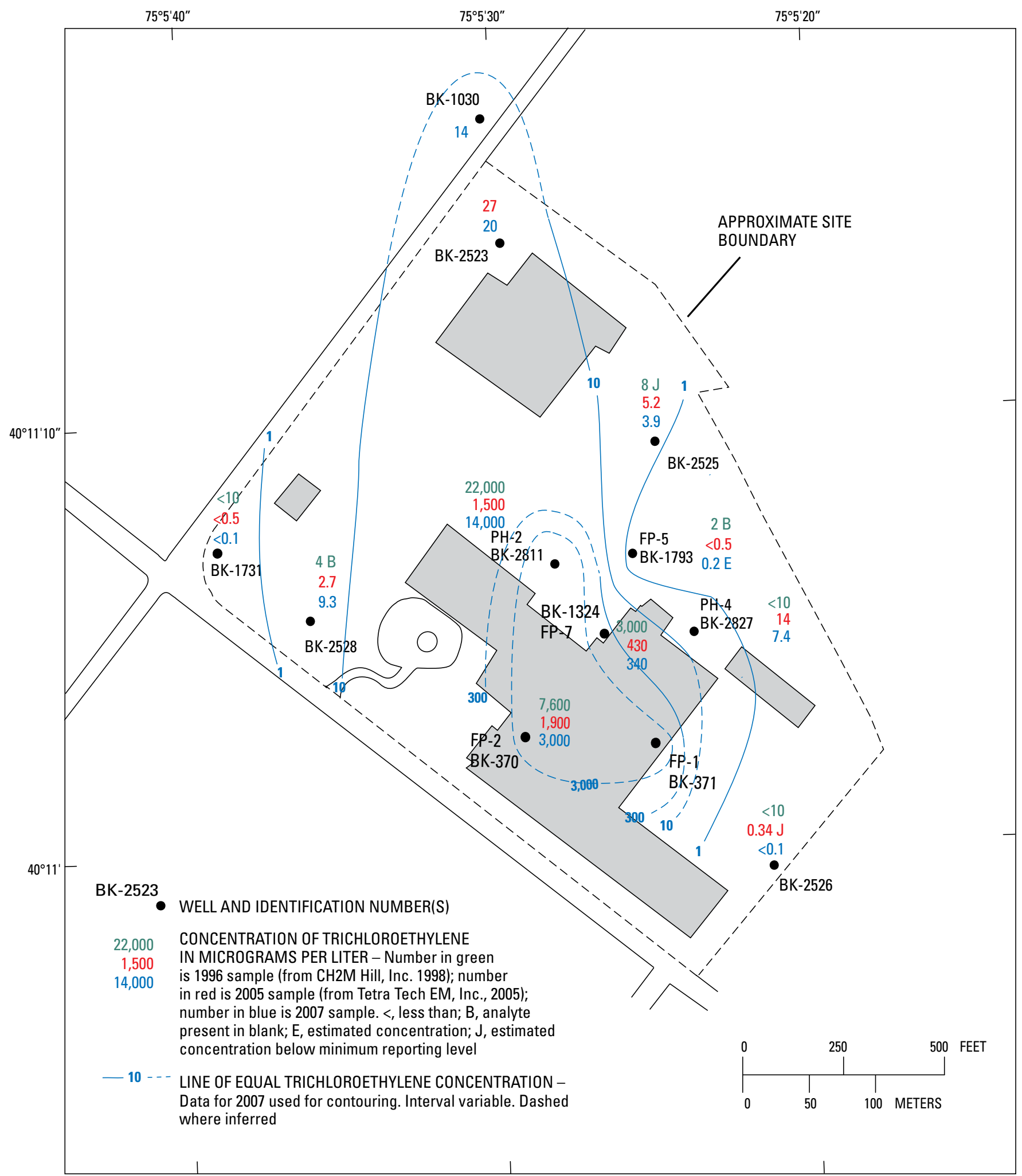

Base from U.S. Geological Survey digital data,1972, 1:2,000,000 Albers Equal-Area Conic Projection.

Standard parallels $29^{\circ} 30^{\prime} \mathrm{N}$, central meridian $75^{\circ} 00^{\prime} \mathrm{W}$.

Figure 37. Concentration of trichloroethylene in water samples from wells completed in the shallow zone, Fischer and Porter Superfund Site, Warminster Township, Bucks County, Pennsylvania, 1996-2007. 


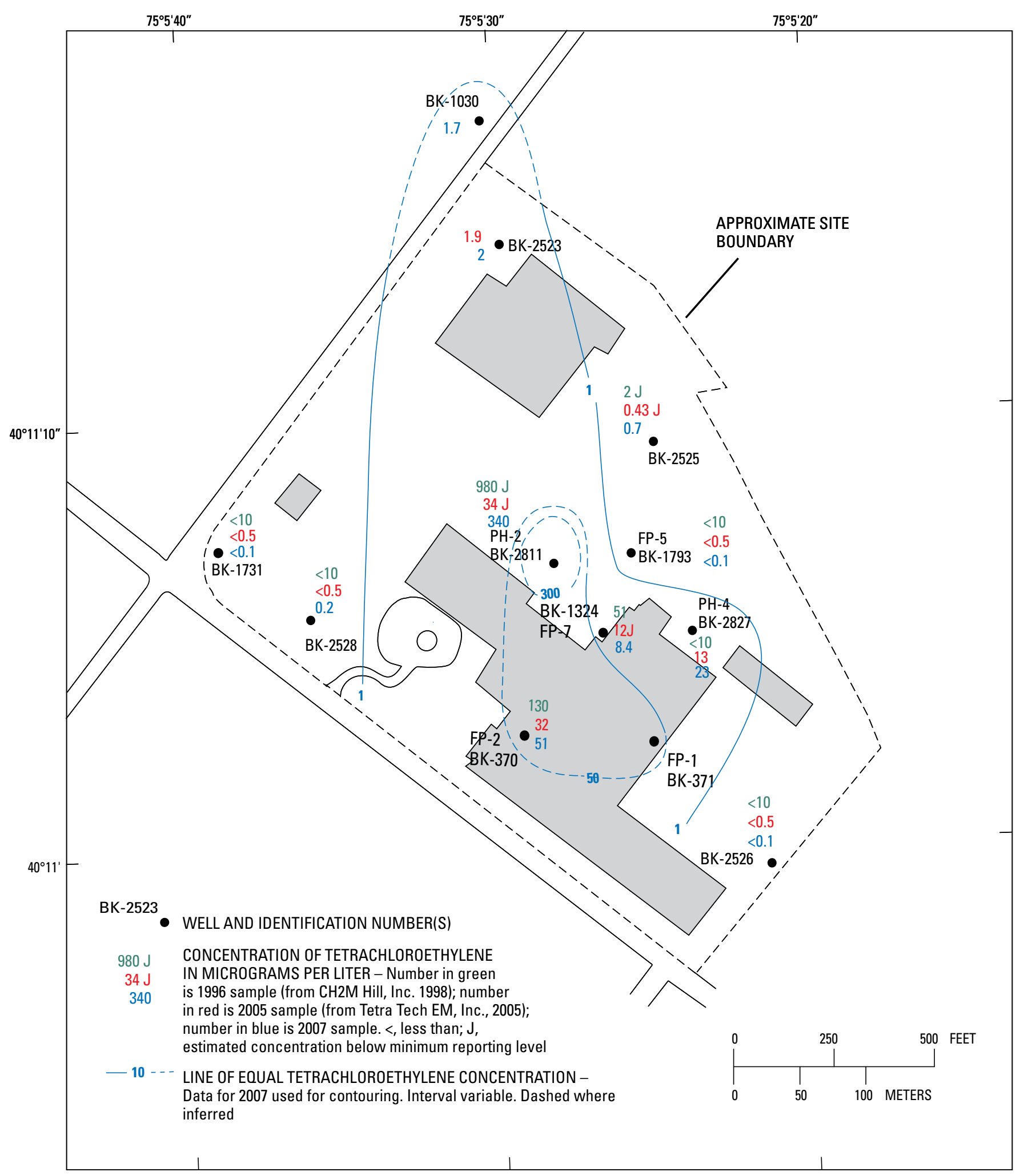

Base from U.S. Geological Survey digital data,1972, 1:2,000,000 Albers Equal-Area Conic Projection. Standard parallels $29^{\circ} 30^{\prime} \mathrm{N}$, central meridian $75^{\circ} 00^{\prime} \mathrm{W}$.

Figure 38. Concentration of tetrachloroethylene in water samples from wells completed in the shallow zone, Fischer and Porter Superfund Site, Warminster Township, Bucks County, Pennsylvania, 1996-2007. 


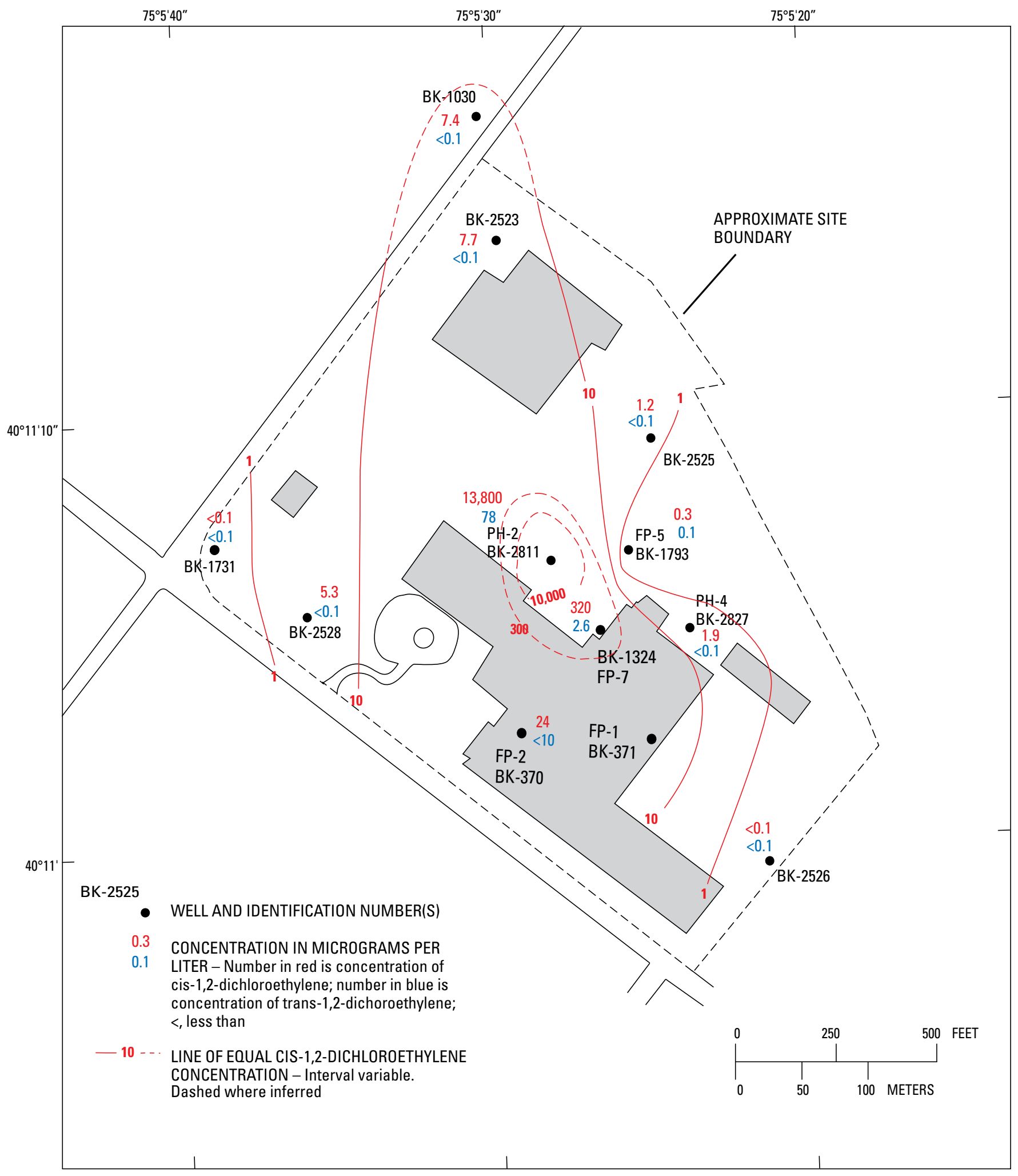

Base from U.S. Geological Survey digital data,1972, 1:2,000,000 Albers Equal-Area Conic Projection. Standard parallels $29^{\circ} 30^{\prime} \mathrm{N}$, central meridian $75^{\circ} 00^{\prime} \mathrm{W}$.

Figure 39. Concentration of cis-1,2-dichloroethylene and trans-1,2-dichloroethylene in water samples from wells completed in the shallow zone, Fischer and Porter Superfund Site, Warminster Township, Bucks County, Pennsylvania, 2007. 
included with the on-site intermediate-depth wells because they are screened in the same lithostratigraphic units as the on-site intermediate-depth wells. For 2007-09, TCE concentrations measured in water samples from on-site intermediatedepth monitor wells ranged from less than 0.1 to $500 \mu \mathrm{g} / \mathrm{L}$

(fig. 40). The highest TCE concentration was in water samples from downgradient monitor well BK-2522. The TCE plume extended off-site to the north and northwest of the source area (fig. 40). The plume followed the hydraulic gradient in the intermediate zone (fig. 17). Concentrations of TCE in water samples from wells east of the source area (BK-2524 and BK-2810) decreased from 1996 to 2007. Concentrations of TCE in water samples north (BK-2522) and west (BK-2521 and BK-2527) of the source area increased from 1996 to 2007.

For 2007-09, PCE concentrations measured in water samples from on-site intermediate-depth monitor wells ranged from 1.3 to $28 \mu \mathrm{g} / \mathrm{L}$ (fig. 41). The highest PCE concentration was in water samples from downgradient monitor well BK-2522. The PCE plume extended off-site to the north of the source area (fig. 41). The plume followed the hydraulic gradient in the intermediate zone (fig. 17). Concentrations of PCE in water samples from wells from 1996 to 2007 were variable.

For 2007-09, concentrations of degradation product cis-1,2-DCE measured in water samples from on-site intermediate-depth monitor wells ranged from less than 0.1 to $270 \mu \mathrm{g} / \mathrm{L}$ (fig. 42), and concentrations of degradation product trans-1,2-DCE ranged from less than 0.1 to $4.1 \mu \mathrm{g} / \mathrm{L}$ (fig. 42 ). Concentrations of cis-1,2-DCE were higher than concentrations of trans-1,2-DCE where the concentrations exceeded the detection limit. The highest concentration of cis-1,2-DCE was in water samples from downgradient well BK-2522. These compounds were formed by the breakdown of TCE, and the plume had the same configuration as the TCE plume.

For 2007, the TCE concentrations measured in water samples from on-site deep monitor wells ranged from 1.1 to $86 \mu \mathrm{g} / \mathrm{L}$ (fig. 43). The highest concentration of TCE was in water samples from downgradient monitor well BK-2512. The TCE plume extended off-site to the northwest of the source area (fig. 43) and generally followed the hydraulic gradient in the deep zone (fig. 21). Well BK-3034, which was flowing in 2007, may have influenced groundwater flow and movement of TCE in the deep zone. In general, concentrations of TCE in water samples for deep monitor wells increased between 1996 and 2005 and decreased between 2005 and 2007; concentrations were less in 2007 than in 1996.

For 2007, PCE concentrations measured in water samples from on-site deep monitor wells ranged from less than 0.1 to $8.4 \mu \mathrm{g} / \mathrm{L}$ (fig. 44). The highest PCE concentration was in a water sample from downgradient monitor well BK-2512. The PCE plume extended off-site to the northwest of the source area (fig. 44) and generally followed the hydraulic gradient in the deep zone (fig. 20). Well BK-3034, which was flowing in 2007, may have influenced groundwater flow and movement of PCE in the deep zone. Concentrations of PCE in water samples for monitor wells outside the source area were less than $10 \mu \mathrm{g} / \mathrm{L}$ in 2007.
For 2007, concentrations of degradation product cis-1,2-DCE measured in water samples from on-site deep monitor wells ranged from less than 0.1 to $13 \mu \mathrm{g} / \mathrm{L}$ (fig. 45), and concentrations of degradation product trans-1,2-DCE ranged from less than 0.1 to $0.2 \mu \mathrm{g} / \mathrm{L}$ (fig. 45). Concentrations of cis-1,2-DCE were higher than concentrations of trans-1,2-DCE for all wells where the concentrations exceeded the detection limit. The highest concentrations of these compounds were in water samples from downgradient monitor well BK-2515. These compounds were formed by the breakdown of TCE, and the plume had the same configuration as the TCE plume.

In 2007, the vinyl chloride concentration measured in groundwater samples from all wells ranged from less than 0.2 to $5,000 \mu \mathrm{g} / \mathrm{L}$ (fig. 46). The highest vinyl chloride concentration was in a water sample from monitor well BK-2811, which is near the source area. The presence of vinyl chloride indicates that reductive dehalogenation of TCE is occurring. Vinyl chloride was detected in water samples from 6 of the 24 wells sampled. Vinyl chloride was measured above the minimum detection limit (less than $0.2 \mu \mathrm{g} / \mathrm{L}$ ) in water samples from one remediation well (FP-7), two shallow wells (FP-5 and PH-2), two intermediate-depth wells (PH-1 and BK-2522), and one deep well (BK-2515).

\section{Vertical Distribution of Volatile Organic Compounds}

The specific gravity of a substance is usually referenced to pure water, which is taken to be 1 gram per milliliter. TCE and PCE are heavier than water with a specific gravity of 1.46 and 1.62, respectively; therefore, a spill or leak of sufficient magnitude is likely to move downward through the subsurface until lower-permeability features impede its progress. This commonly results in formation of a plume along a downward path in the aquifer.

TCE concentrations measured in water samples from wells along section A-C are shown on figure 47, and PCE concentrations are shown on figure 48. The highest TCE and PCE concentrations away from the source area were measured in water samples from wells BK-2521 and BK-2527, which are screened in stratigraphic unit 3 . As of 2007, TCE and PCE appeared to be moving downdip through stratigraphic unit 3 . The downdip extent of TCE and PCE migration extended approximately $550 \mathrm{ft}$ off-site to the northwest and $750 \mathrm{ft}$ off-site to the north. TCE concentrations in water samples from wells BK-2521 increased from 52 to $100 \mu \mathrm{g} / \mathrm{L}$ and from BK-2527 increased from 210 to $240 \mu \mathrm{g} / \mathrm{L}$ from 1996 to 2007.

TCE concentrations measured in water samples from wells along section B-C are shown on figure 49, and PCE concentrations are shown on figure 50. The highest concentrations of TCE away from the source area were in water samples from wells BK-2522 and BK-2512, which are screened in stratigraphic units 2, 3, and 4 . The highest PCE concentration measured away from the source area was in water samples 


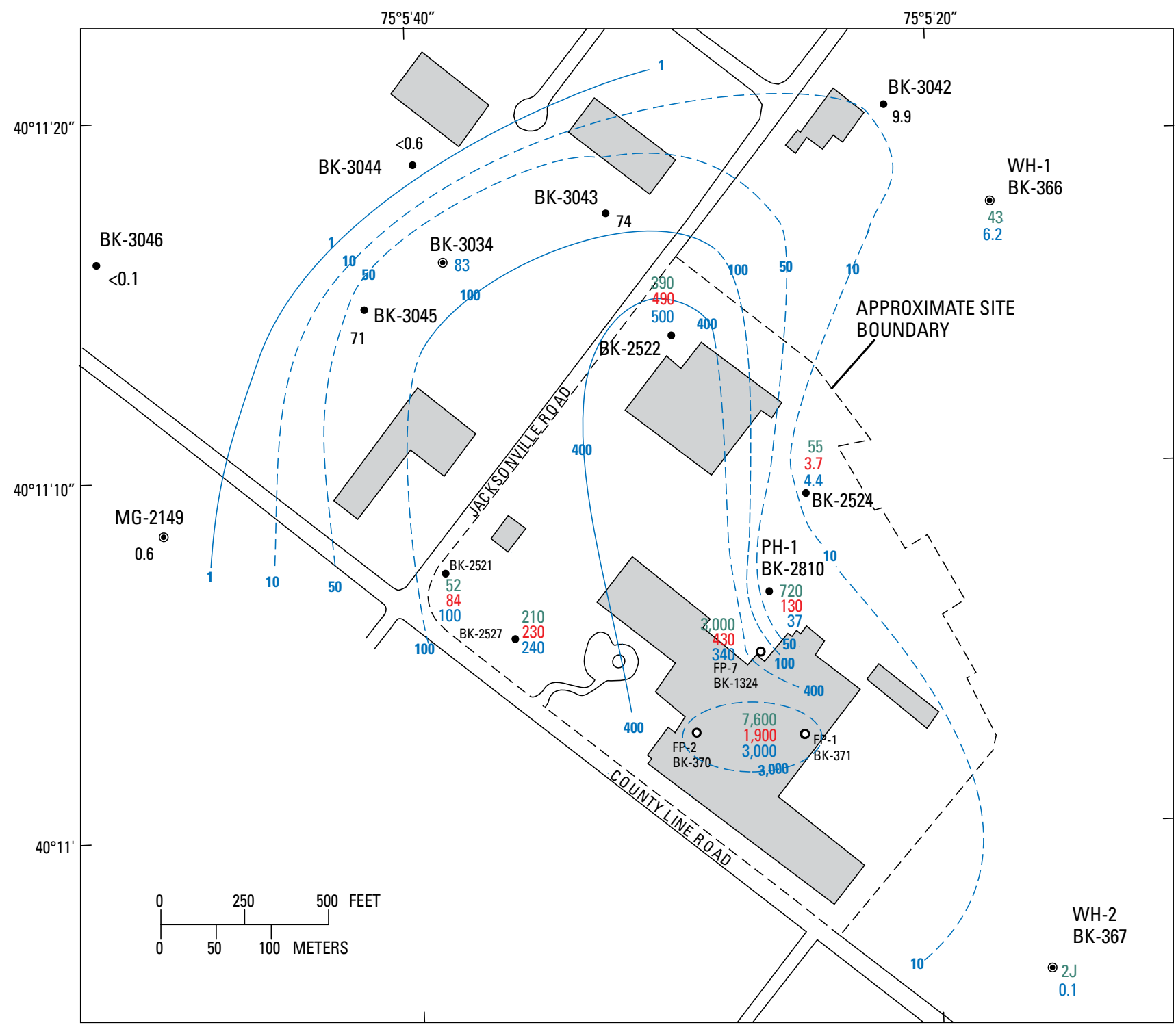

Base from U.S. Geological Survey digital data,1972, 1:2,000,000 Albers Equal-Area Conic Projection. Standard parallels $29^{\circ} 30^{\prime} \mathrm{N}$, central meridian $75^{\circ} 00^{\prime} \mathrm{W}$.

\section{EXPLANATION}

$\begin{aligned} & \text { WELL AND IDENTI } \\ & \text { NUMBER(S) } \\ \text { BK-2511 } & \bullet \text { Monitor well } \\ \text { FP-1 } & \text { O Extraction well } \\ \text { BK-371 } & \\ \text { WH-1 } & \bigcirc \text { Open-hole well } \\ \text { BK-366 } & \end{aligned}$

20 CONCENTRATION OF TRICHLOROETHYLENE

130 IN MICROGRAMS PER LITER - Number in green is 1996 sample (from CH2M Hill, Inc. 1998); number in red is 2005 sample (from Tetra Tech EM, Inc., 2005); number in blue is 2007 sample; number in black is 2008-09 sample; <, less than; J, estimated concentration below minimum reporting leve

- 10 -- LINE OF EQUAL TRICHLOROETHYLENE CONCENTRATION Data for 2007-09 used for contouring. Interval variable. Dashed where inferred

Figure 40. Concentration of trichloroethylene in water samples from on-site wells completed in the intermediate zone and offsite wells completed in the deep zone, Fischer and Porter Superfund Site, Warminster Township, Bucks County, Pennsylvania, 1996-2009. 


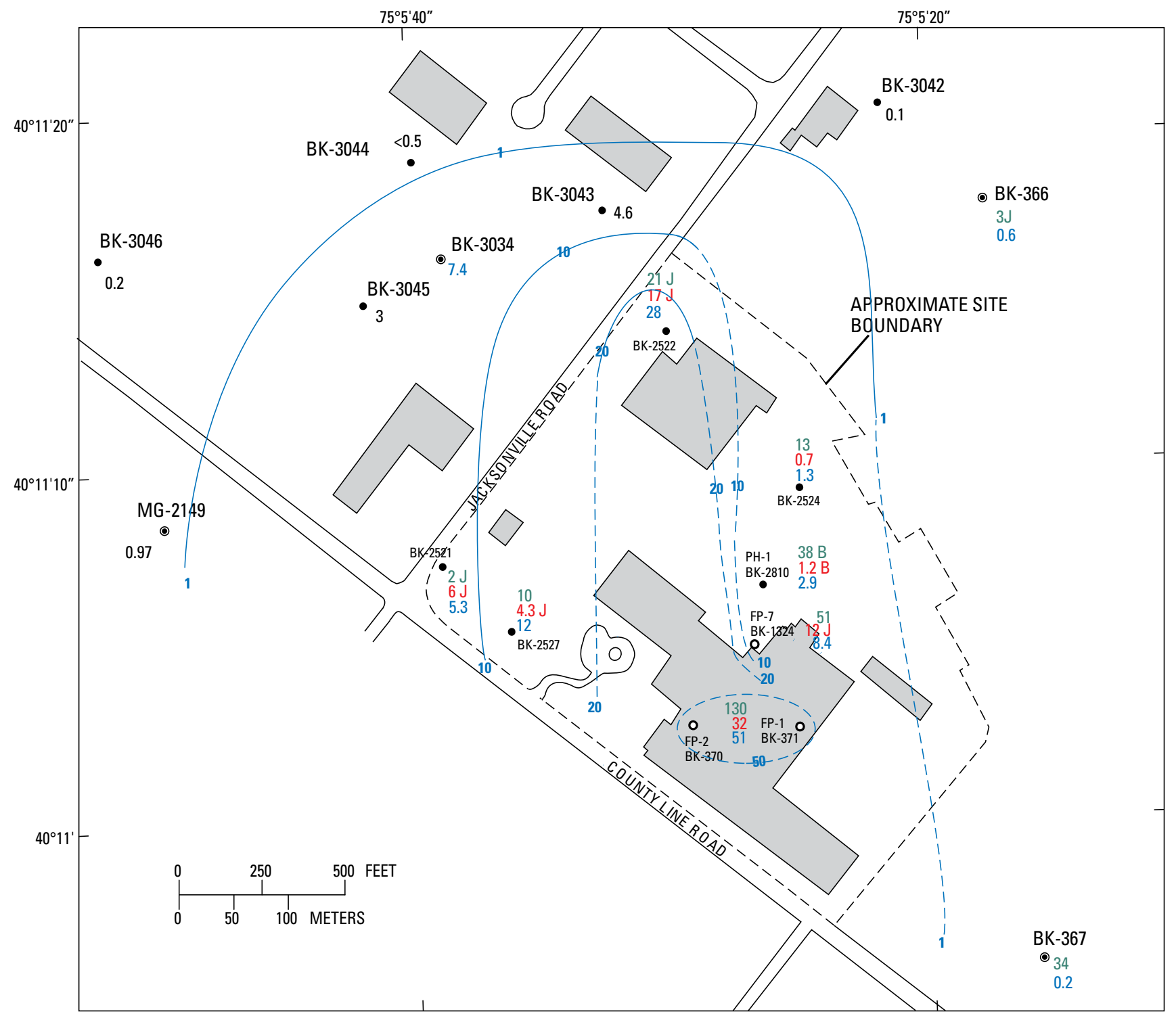

Base from U.S. Geological Survey digital data, 1972, 1:2,000,000 Albers Equal-Area Conic Projection.

Standard parallels $29^{\circ} 30^{\prime} \mathrm{N}$, central meridian $75^{\circ} 00^{\prime} \mathrm{W}$.

\section{EXPLANATION}

WELL AND IDENTIFICATION $\operatorname{NUMBER}(S)$

$\begin{aligned} \text { BK-2511 } & \bullet \text { Monitor well } \\ \text { FP-1 } & \circ \text { Extraction well } \\ \text { BK-371 } & \\ \text { WH-1 } & \bigcirc \text { Open-hole well } \\ \text { BK-366 } & \end{aligned}$

CONCENTRATION OF TETRACHLOROETHYLENE

IN MICROGRAMS PER LITER - Number in green

is 1996 sample (from CH2M Hill, Inc. 1998); number

in red is 2005 sample (from Tetra Tech EM, Inc., 2005);

number in blue is 2007 sample; number in black is 2008-09

sample; <, less than; B, analyte present in blank; J, estimated concentration below minimum reporting level

- 10 - - LINE OF EQUAL TETRACHLOROETHYLENE CONCENTRATION Data for 2007-09 used for contouring. Interval variable. Dashed where inferred

Figure 41. Concentration of tetrachloroethylene in water samples from on-site wells completed in the intermediate zone and off-site wells completed in the deep zone, Fischer and Porter Superfund Site, Warminster Township, Bucks County, Pennsylvania, 1996-2009. 


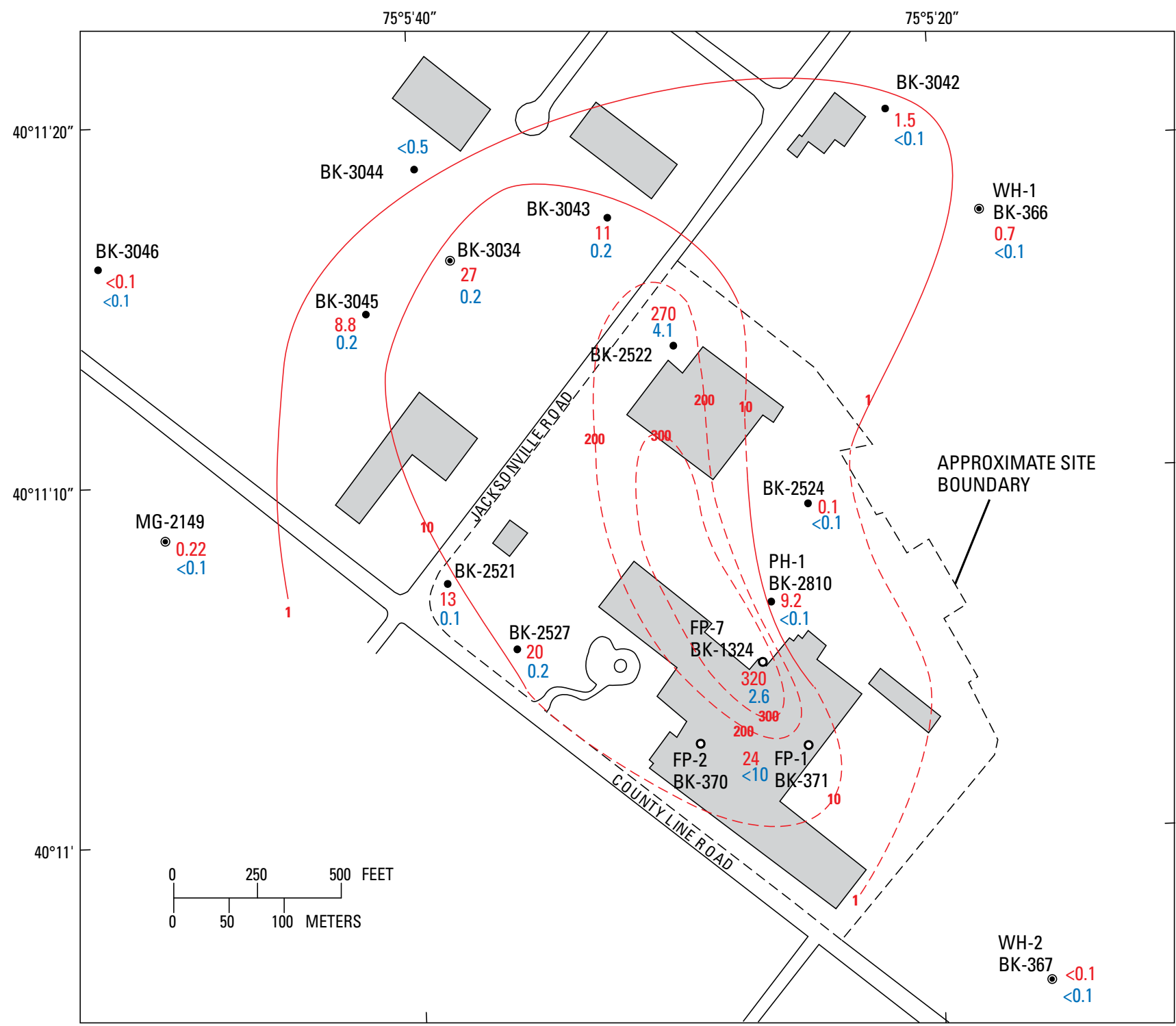

Base from U.S. Geological Survey digital data,1972, 1:2,000,000 Albers Equal-Area Conic Projection. Standard parallels $29^{\circ} 30^{\prime} \mathrm{N}$, central meridian $75^{\circ} 00^{\prime} \mathrm{W}$.

\section{EXPLANATION}

\section{WELL AND IDENTIFICATION NUMBER(S)}

\section{BK-2511 Monitor well \\ FP-1 O Extraction well \\ BK-371 \\ WH-1 O Open-hole well}

BK-366

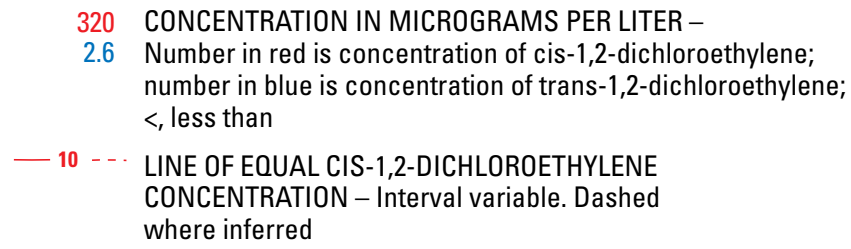

CONCENTRATION IN MICROGRAMS PER LITER umber in blue is concentration of trans-1,2-dichloroethylene;

INE OF EOUAL CIS-1,2-DICHLOROETHYLENE where inferred

Figure 42. Concentration of cis-1,2-dichloroethylene and trans-1,2-dichloroethylene in water samples from on-site wells completed in the intermediate zone and off-site wells completed in the deep zone, Fischer and Porter Superfund Site, Warminster Township, Bucks County, Pennsylvania, 2007. 


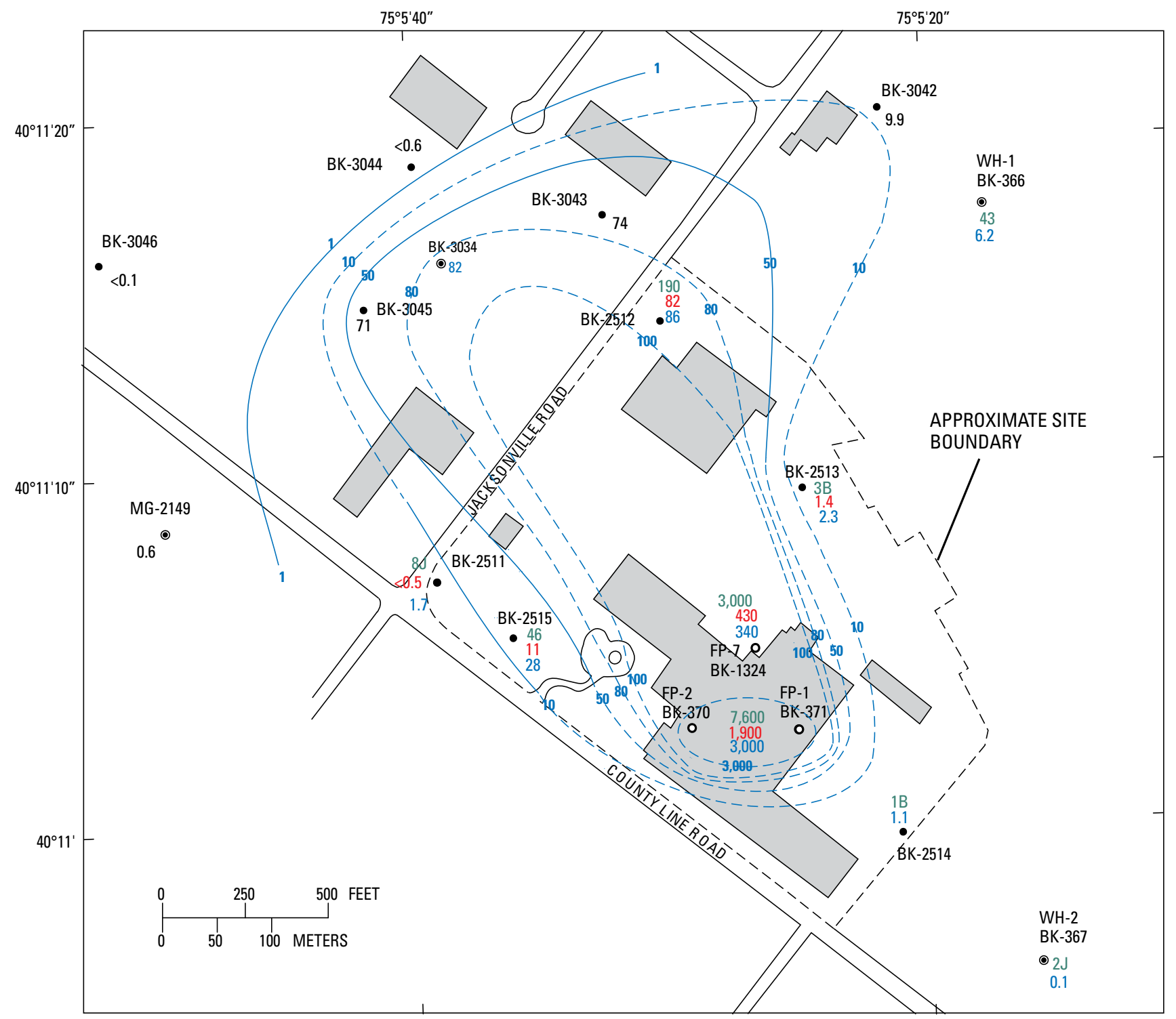

Base from U.S. Geological Survey digital data,1972, 1:2,000,000 Albers Equal-Area Conic Projection. Standard parallels $29^{\circ} 30^{\prime} \mathrm{N}$, central meridian $75^{\circ} 00^{\prime} \mathrm{W}$.

\section{EXPLANATION}

WELL AND IDENTIFICATION NUMBER(S)

$\begin{aligned} \text { BK-2511 } & \bullet \text { Monitor well } \\ \text { FP-1 } & \text { O Extraction well } \\ \text { BK-371 } & \\ \text { WH-1 } & \bigcirc \text { Open-hole well } \\ \text { BK-366 } & \end{aligned}$

46 CONCENTRATION OF TRICHLOROETHYLENE

11 IN MICROGRAMS PER LITER - Number in green

is 1996 sample (from CH2M Hill, Inc. 1998); number

in red is 2005 sample (from Tetra Tech EM, Inc., 2005)

number in blue is 2007 sample; number in black is 2008-09

sample; <, less than; B, analyte present in blank; J, estimated concentration below minimum reporting level

- 10 - - LINE OF EQUAL TRICHLOROETHYLENE CONCENTRATION -

Data for 2007-09 used for contouring. Interval variable. Dashed where inferred

Figure 43. Concentration of trichloroethylene in water samples from wells open to the deep zone, Fischer and Porter Superfund Site, Warminster Township, Bucks County, Pennsylvania, 1996-2009. 


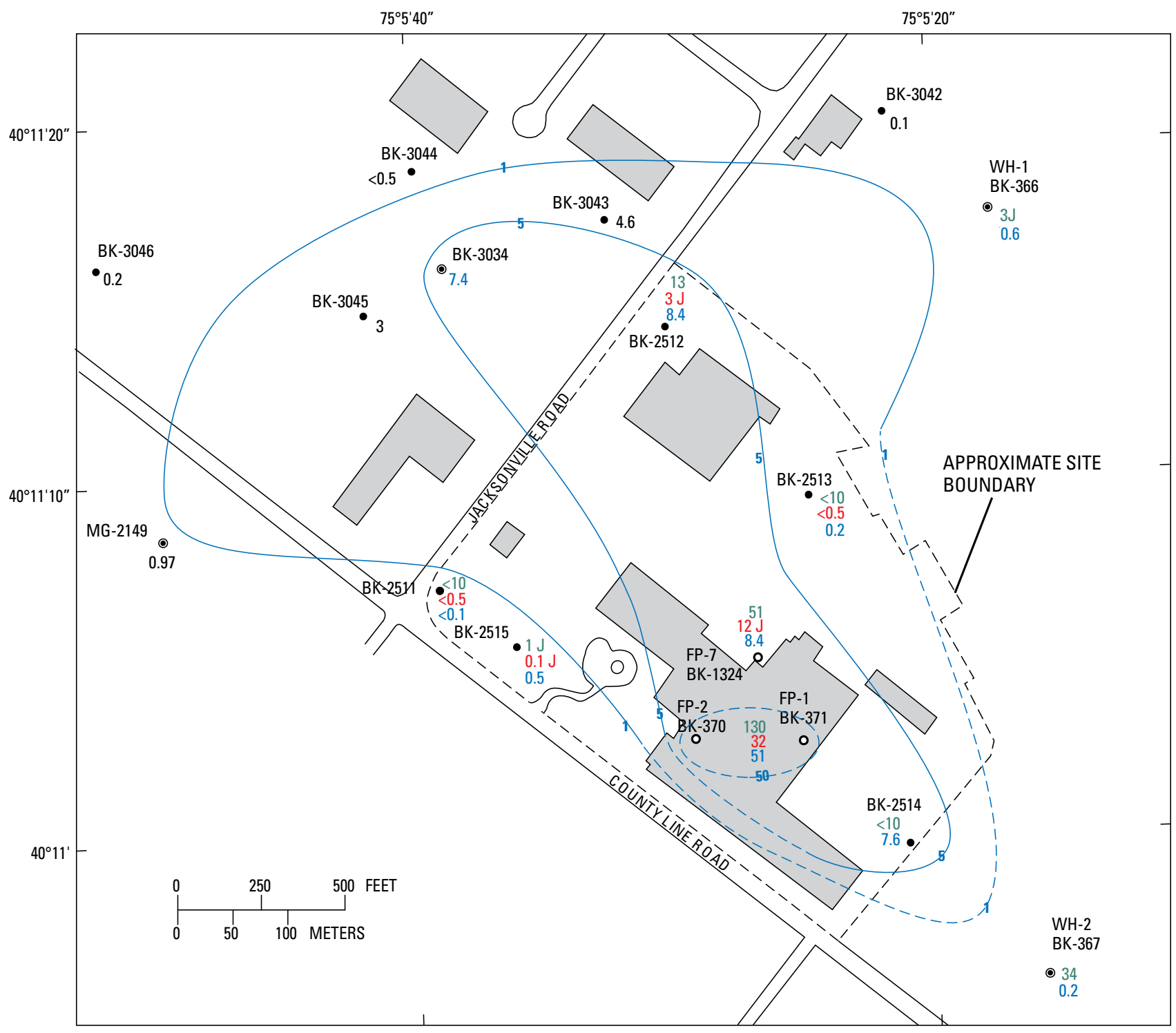

Base from U.S. Geological Survey digital data,1972, 1:2,000,000 Albers Equal-Area Conic Projection. Standard parallels $29^{\circ} 30^{\prime} \mathrm{N}$, central meridian $75^{\circ} 00^{\prime} \mathrm{W}$.

EXPLANATION

$\begin{aligned} & \text { WELL AND IDENT } \\ & \text { NUMBER(S) } \\ & \text { BK-2511 } \bullet \text { Monitor well } \\ & \text { FP-1 } \text { O Extraction well } \\ & \text { BK-371 } \\ & \text { WH-1 } \bigcirc \text { Open-hole well } \\ & \text { BK-366 }\end{aligned}$

CONCENTRATION OF TETRACHLOROETHYLENE

IN MICROGRAMS PER LITER - Number in green

is 1996 sample (from CH2M Hill, Inc. 1998); number

in red is 2005 sample (from Tetra Tech EM, Inc., 2005).

number in blue is 2007 sample; number in black is 2008-09

sample; <, less than; J, estimated concentration below minimum reporting level

- 10 - L LINE OF EQUAL TETRACHLOROETHYLENE CONCENTRATION -

Data for 2007-09 used for contouring. Interval variable. Dashed where inferred

Figure 44. Concentration of tetrachloroethylene in water samples from wells open to the deep zone, Fischer and Porter Superfund Site, Warminster Township, Bucks County, Pennsylvania, 1996-2009. 


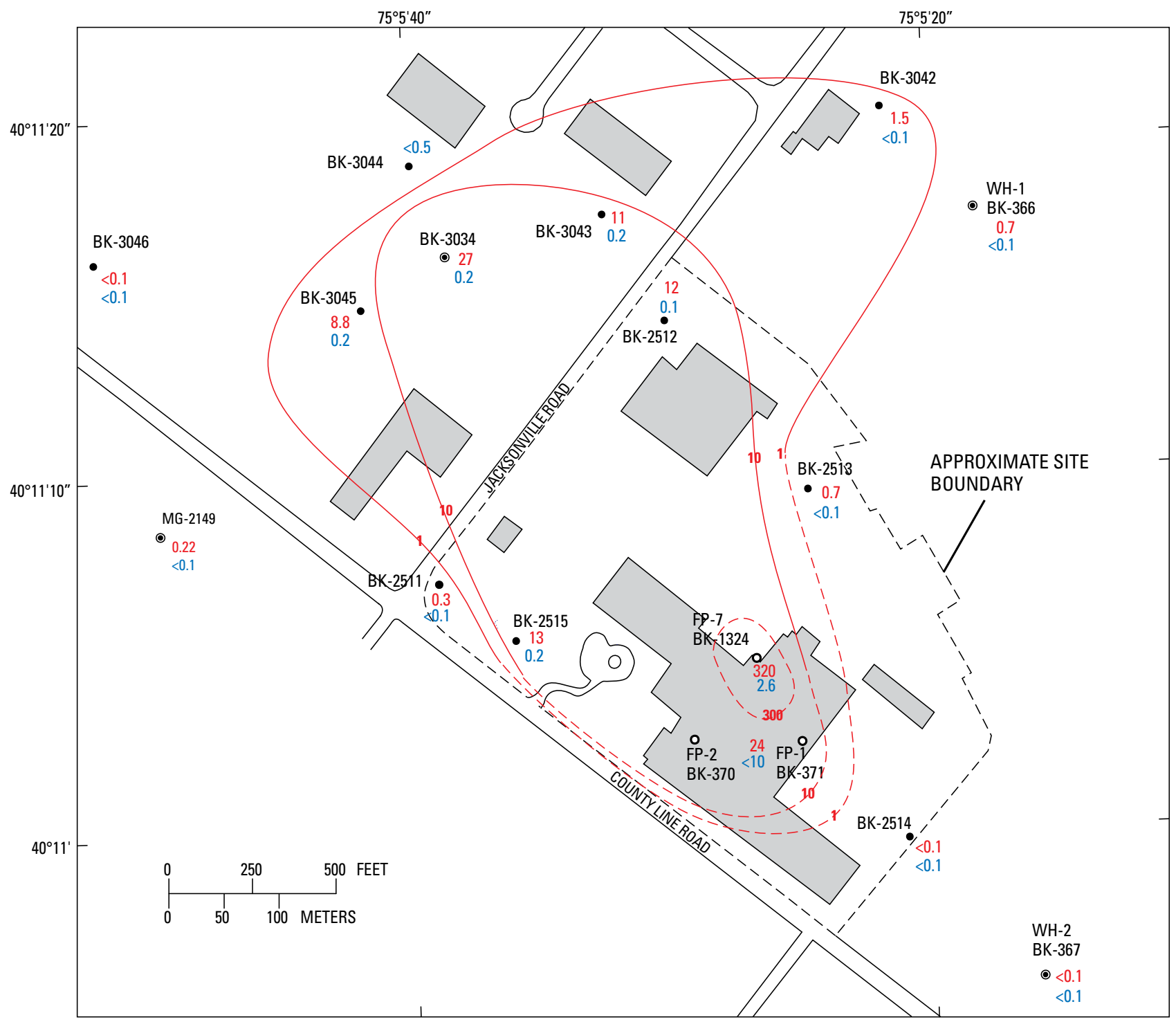

Base from U.S. Geological Survey digital data,1972, 1:2,000,000 Albers Equal-Area Conic Projection.

Standard parallels $29^{\circ} 30^{\prime} \mathrm{N}$, central meridian $75^{\circ} 00^{\prime} \mathrm{W}$.

\section{EXPLANATION}

$\begin{aligned} & \text { WELL AND IDENTIFICATION } \\ & \text { NUMBER(S) } \\ \text { BK-2511 } & \bullet \text { Monitor well } \\ \text { FP-1 } & \text { O Extraction well } \\ \text { BK-371 } & \\ \text { WH-1 } & \text { O Open-hole well } \\ \text { BK-366 } & \end{aligned}$

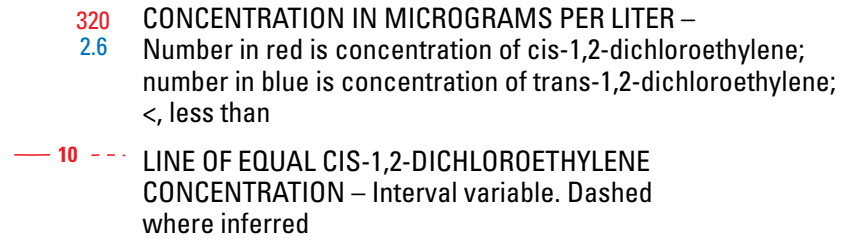

Figure 45. Concentration of cis-1,2-dichloroethylene and trans-1,2-dichloroethylene in water samples from wells open to the deep zone, Fischer and Porter Superfund Site, Warminster Township, Bucks County, Pennsylvania, 2007. 


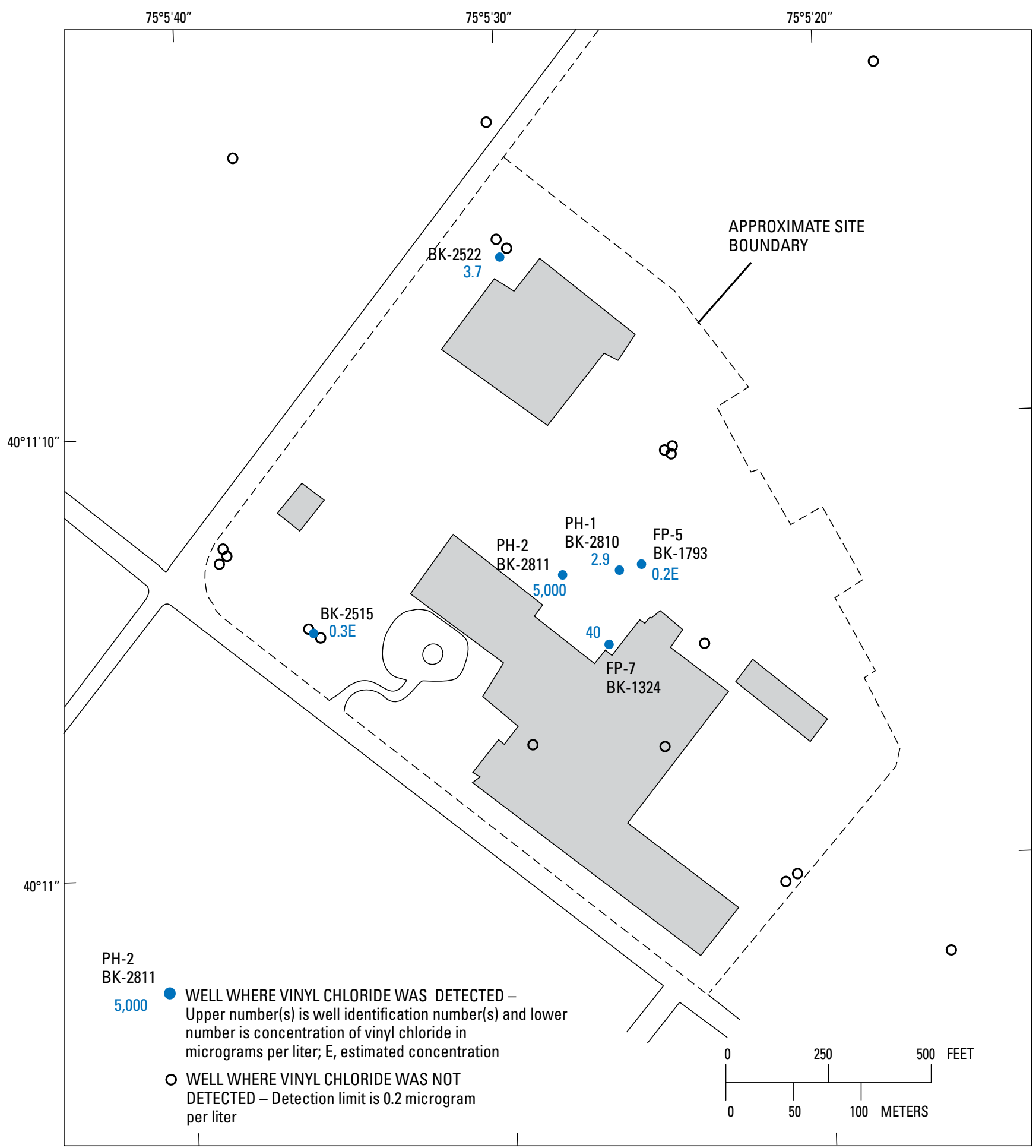

Base from U.S. Geological Survey digital data,1972, 1:2,000,000 Albers Equal-Area Conic Projection. Standard parallels $29^{\circ} 30^{\prime} \mathrm{N}$, central meridian $75^{\circ} 00^{\prime} \mathrm{W}$

Figure 46. Concentration of vinyl chloride measured in water samples from wells at the Fischer and Porter Superfund Site, Warminster Township, Bucks County, Pennsylvania, 2007. 


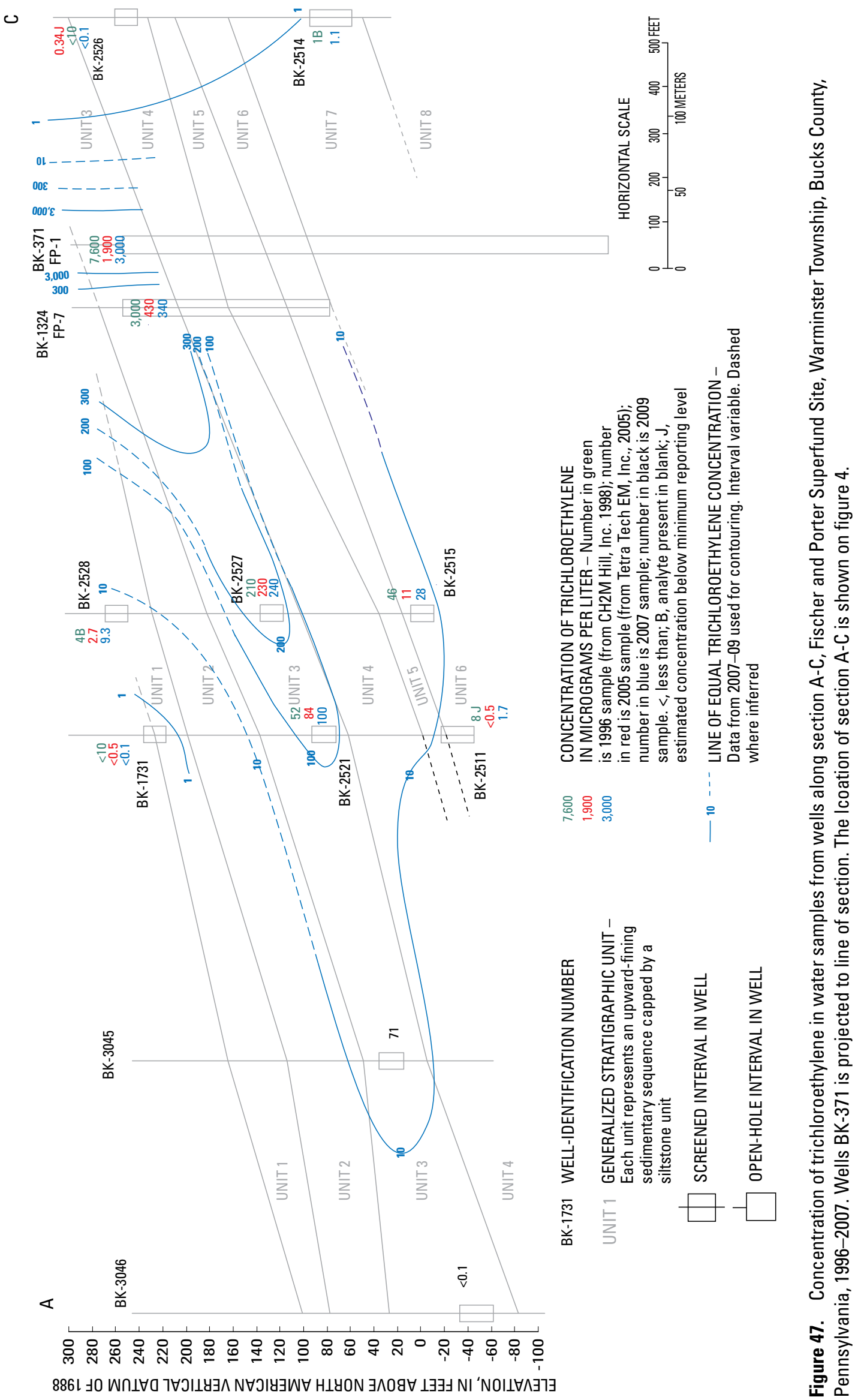




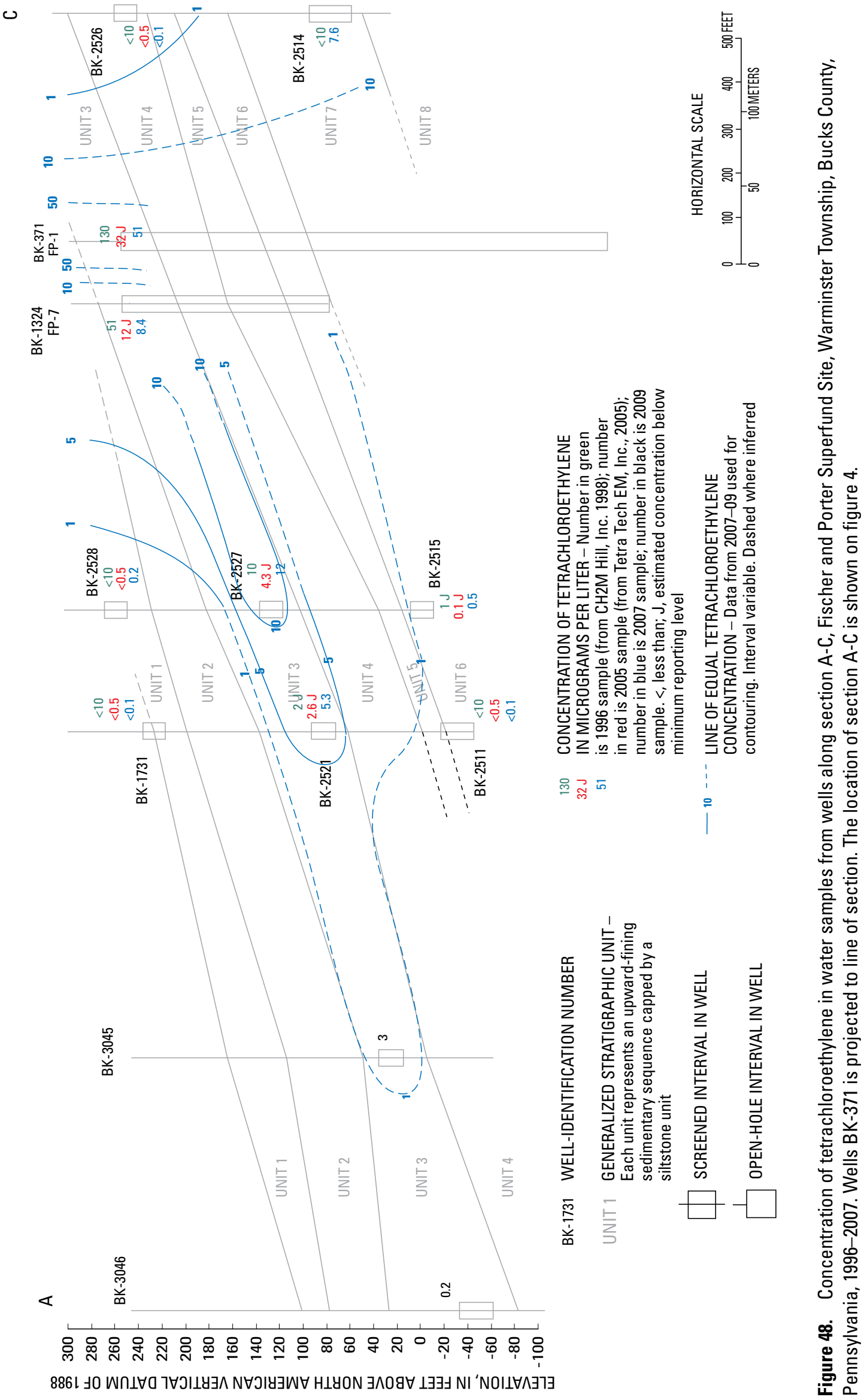




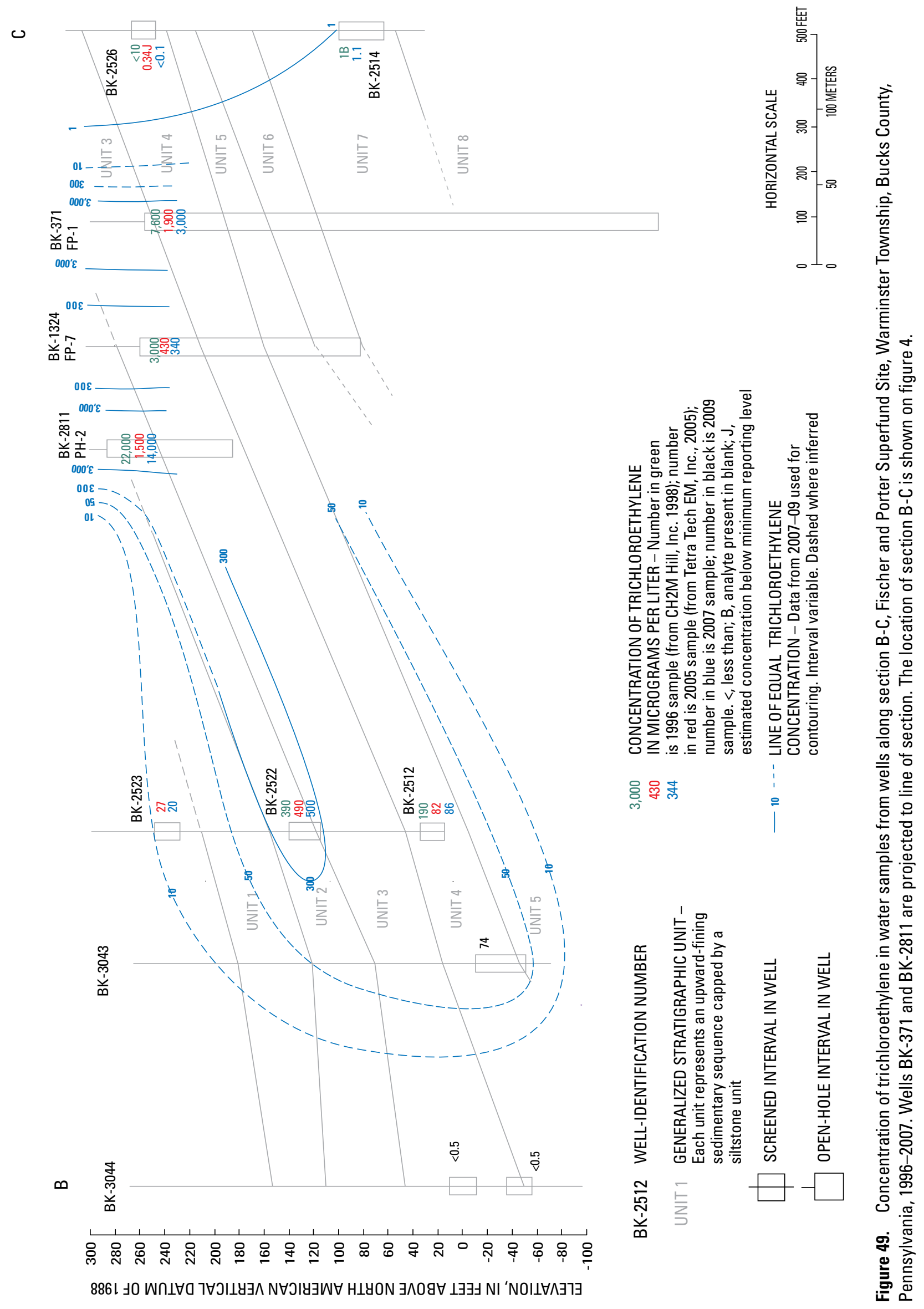


0
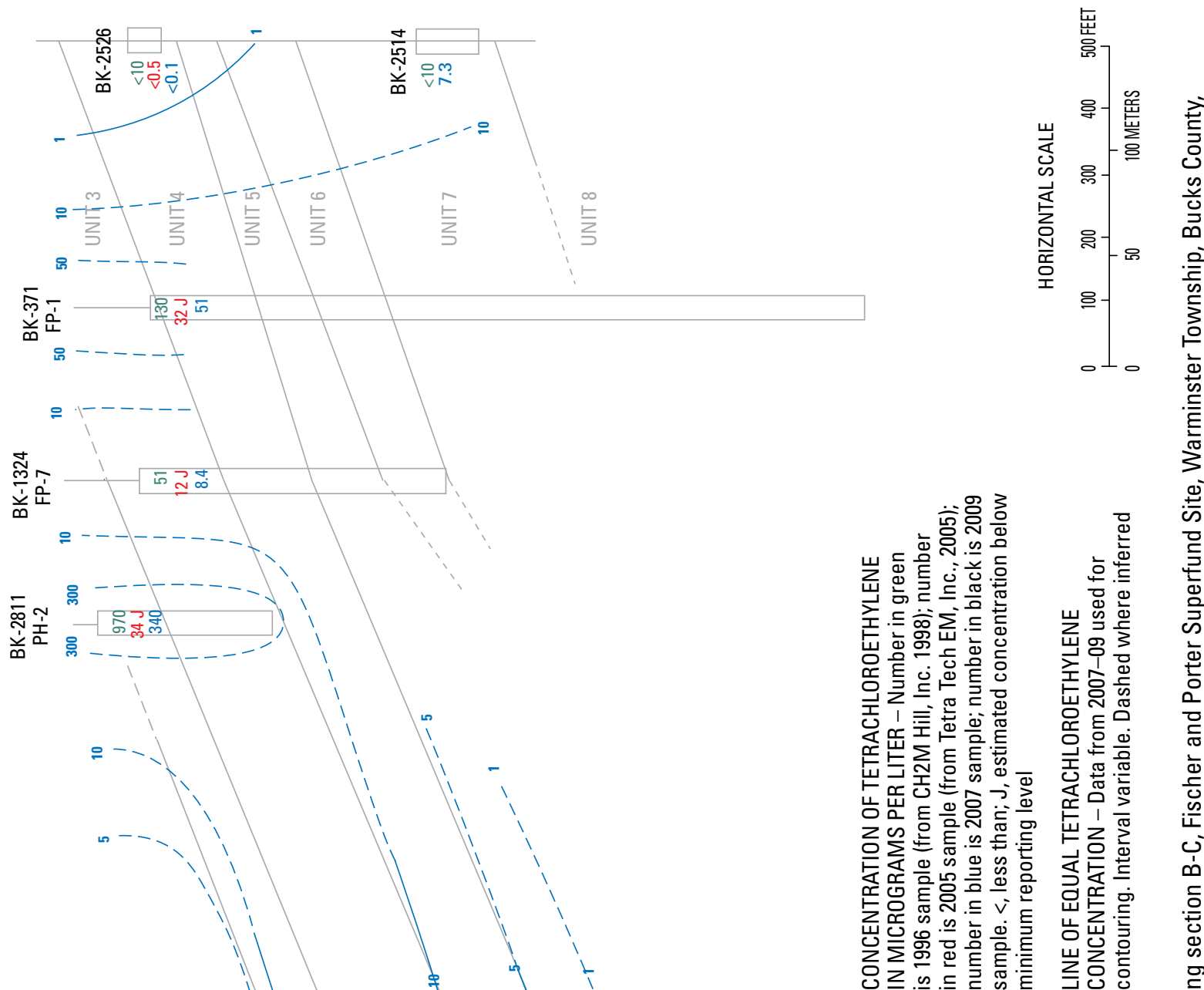

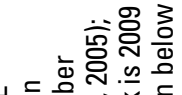

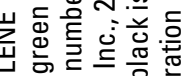

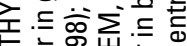

造。航

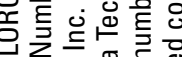

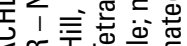

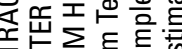

ज胥政要

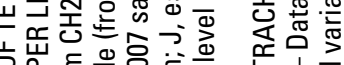

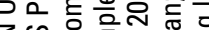

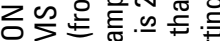

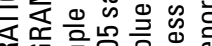

到品v

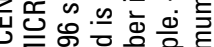

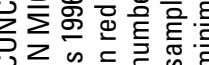

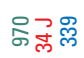

$\infty$
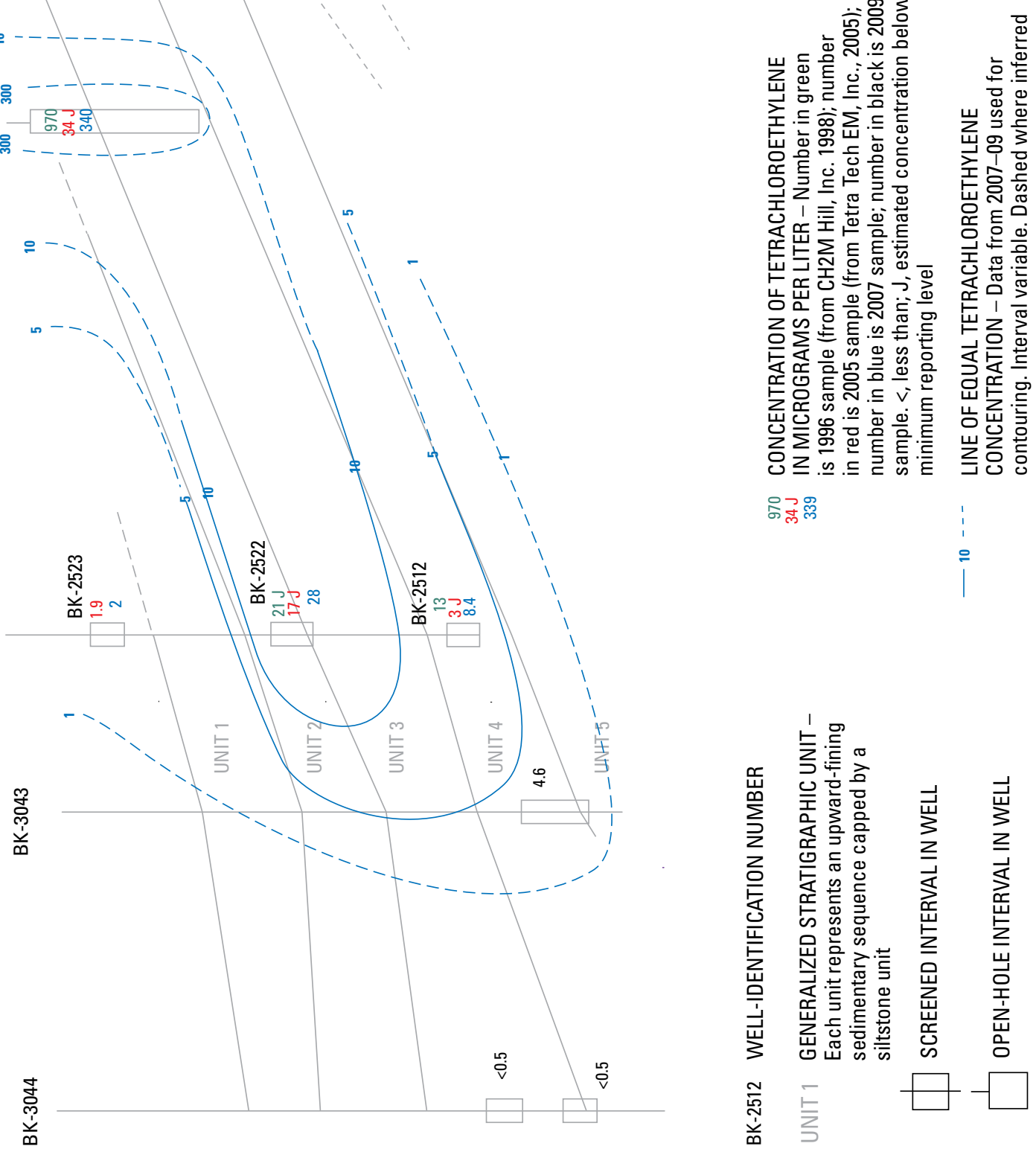

$\stackrel{\circ}{\oplus}$

竞

空

을

के

过

क

등

๘

总

i

ต
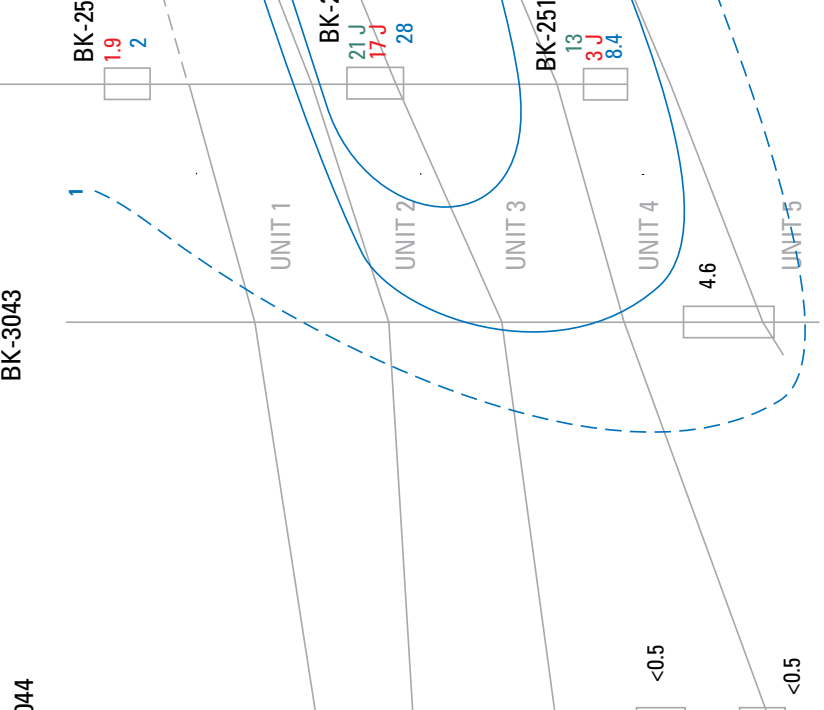

雍

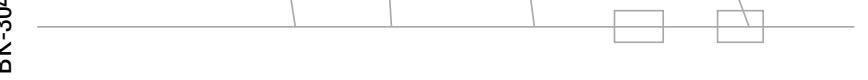

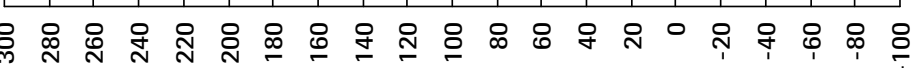


from well BK-2522, which is screened in stratigraphic units 2 and 3. As of 2007, TCE and PCE appeared to be moving laterally and downward through stratigraphic units 2,3 , and 4 .

\section{Migration of Volatile Organic Compounds}

The migration of VOCs from the Fischer and Porter Site is influenced by geologic and hydrologic controls. The hydrologic controls have changed with time.

Geologic controls include the strike and dip of bedding and permeability differences among beds. The bedding dips approximately $9^{\circ} \mathrm{NW}$. (figs. 5 and 6). The direction of the bedding dip is approximately N. $25^{\circ} \mathrm{W}$., which is perpendicular to strike (N. $65^{\circ}$ E.). Rima and others (1962, p. 22) identified three systematic vertical joint sets. The most frequently occurring set was perpendicular to strike. The other two joint sets were parallel or nearly parallel to strike and at an angle of approximately $50^{\circ}$ to strike. In the vicinity of the Fischer and Porter Site, these joint sets would be oriented at approximately N. $25^{\circ}$ W., N. $65^{\circ}$ E., and N. $15^{\circ}$ E., respectively. Hydrologic controls include pumping and flowing wells at and in the vicinity of the Fischer and Porter Site.

The wells at and in the vicinity of the Fischer and Porter Site were initially sampled by SMC Martin, Inc. (1980) in 1979-80. TCE concentrations were as high as $87,000 \mu \mathrm{g} / \mathrm{L}$ onsite and $350 \mu \mathrm{g} / \mathrm{L}$ off-site (fig. 51). At that time, wells BK-366 (Warminster Heights 1), BK-367 (Warminster Heights 2), and MG-946 (Hatboro 16) were active public-supply wells, and wells BK-368 (La Rosa 2), BK-370 (Fischer and Porter 2), and BK-371 (Fischer and Porter 1) were active industrial-supply wells. Groundwater contaminated with VOCs flowed downdip and then northeast along strike toward well BK-366, downdip toward well BK-368, and downdip and then west along strike toward well MG-946.

Sometime between 1980 and 1990, wells BK-368 and MG-946 stopped pumping and were abandoned. In 1984, the Fischer and Porter supply wells BK-370 and BK-371, along with monitor well BK-1731, became remediation wells pumped continuously at a combined rate of $75 \mathrm{gal} / \mathrm{min}$. The Warminster Heights wells continued to be pumped until 2004. Potentiometric-surface maps published by BCM, Inc. (1986, figs. 4-6) showed groundwater flow to the north toward Warminster Heights well WH-1.

In 1993, additional monitor wells were drilled at the Fischer and Porter Site by the USGS to provide detailed geologic, hydrologic, and water-quality data. Data from the intermediate-depth wells in 1993-94 (Sloto and others, 1995, p. 42) and 1996 (CH2M Hill, Inc., 1998, p. 3-19 and 3-21) indicated that the groundwater-flow direction generally was to the north when Warminster Heights well WH-1 was pumping. The direction of groundwater flow in the intermediate-depth zone was influenced by the pumping of well WH-1. Data from the deep wells indicated that the direction of groundwater flow was to the west and southwest in 1993-94 (Sloto and others,
1995, p. 42) and to the northeast toward well WH-1 in 1996 (CH2M Hill, Inc., 1998, p. 3-20 and 3-23).

The Warminster Heights wells stopped pumping in 2004. Potentiometric-surface maps constructed with data from both the intermediate and deep wells show the direction of groundwater flow shifted from the north to the northwest since well WH-1 stopped pumping.

Section E-C (fig. 4) is the closest section to the Warminster Heights wells. In 1993, groundwater gradients in the vicinity of wells BK-2514 and BK-2526 were towards the Fischer and Porter Site remediation wells and downward. In 2006-09, vertical groundwater gradients were toward the remediation wells. The downward gradient was still present, but it was less than when Warminster Heights well WH-2 was pumping. On the west side of the Fisher and Porter Site near Warminster Heights well WH-1, the data generally were too variable to suggest a consistent change in the vertical gradient. Section D-E (fig. 4) is approximately along strike at the northwestern boundary of the Fischer and Porter Site. In 1993, groundwater flow was from south to north with a general downward vertical gradient. Water levels measured in 2006-09 also showed groundwater flow from south to north; however, the vertical gradient between the deep and the intermediate zone was upward instead of downward. This reversal of the vertical hydraulic gradient likely was caused by cessation of pumping of well WH-1.

The movement of VOCs from the Fischer and Porter Site may have been influenced by well BK-3034. This unused $300-\mathrm{ft}$ deep open-hole well was in an overgrown, wooded area along Pennypack Creek. When this well was initially found about 1979, it was filled with rocks and debris and was not flowing. When the well was visited in 2007, it was still filled with rocks and debris, and it was flowing at an estimated 20-30 gal/min. Cessation of local pumping likely caused the water level to rise above the top of the casing, and the well began flowing. It is not known how long the well flowed. When flowing, it acted as a withdrawal well. The well was abandoned (grouted shut) in 2008.

Stratigraphic units 2 and 3 crop out beneath the former Fischer and Porter plant (fig. 52). VOCs originating at the plant entered these stratigraphic units and moved downdip. The plume then spread out laterally along strike in response to pumping of public-supply wells. The long axis of the plume (fig. 40) is oriented about N. $18^{\circ} \mathrm{W}$. in the direction of dip. This direction also coincides with the predominant joint set in the Stockton Formation (N. $25^{\circ}$ W.) and it also is the direction of the hydraulic gradient in the intermediate and deep zones (fig. 21).

The leading edge of the plume spread laterally under hydraulic gradients created by the pumping of public-supply wells MG-946 and BK-366. In 1979-80, the leading edge of the plume was about $3,500 \mathrm{ft}$ wide (fig. 51). With the cessation of pumping and the biodegradation of TCE and PCE, the size of the plume decreased. In 2007-09, the plume was approximately 2,000 ft long and 2,000 ft wide at the leading edge (fig. 40). 


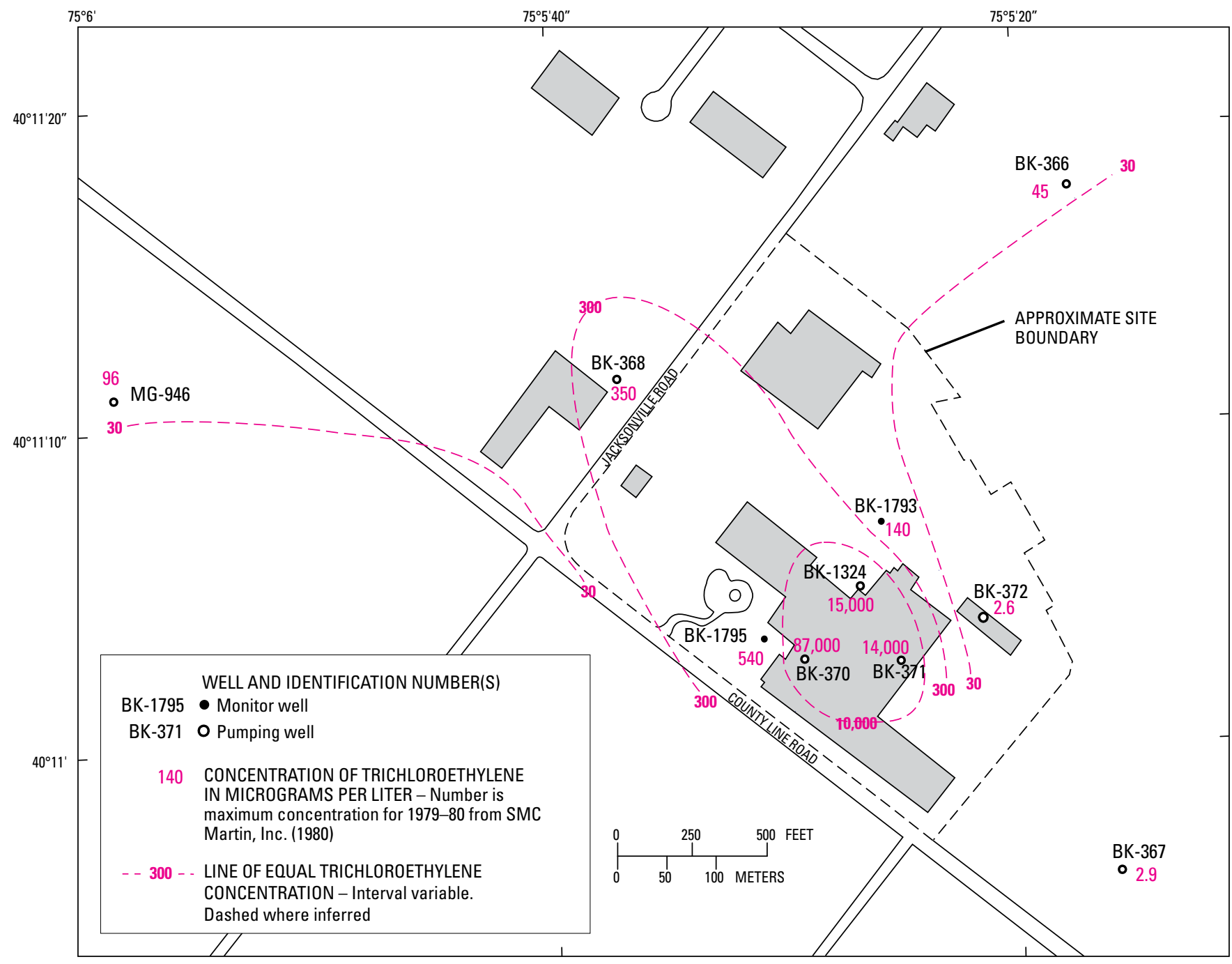

Base from U.S. Geological Survey digital data,1972, 1:2,000,000 Albers Equal-Area Conic Projection. Standard parallels $29^{\circ} 30^{\prime} \mathrm{N}$, central meridian $75^{\circ} 00^{\prime} \mathrm{W}$.

Figure 51. Maximum concentration of trichloroethylene in groundwater samples, Fischer and Porter Superfund Site, Warminster Township, Bucks County, Pennsylvania, 1979-80. Data from SMC Martin, Inc. (1980). 


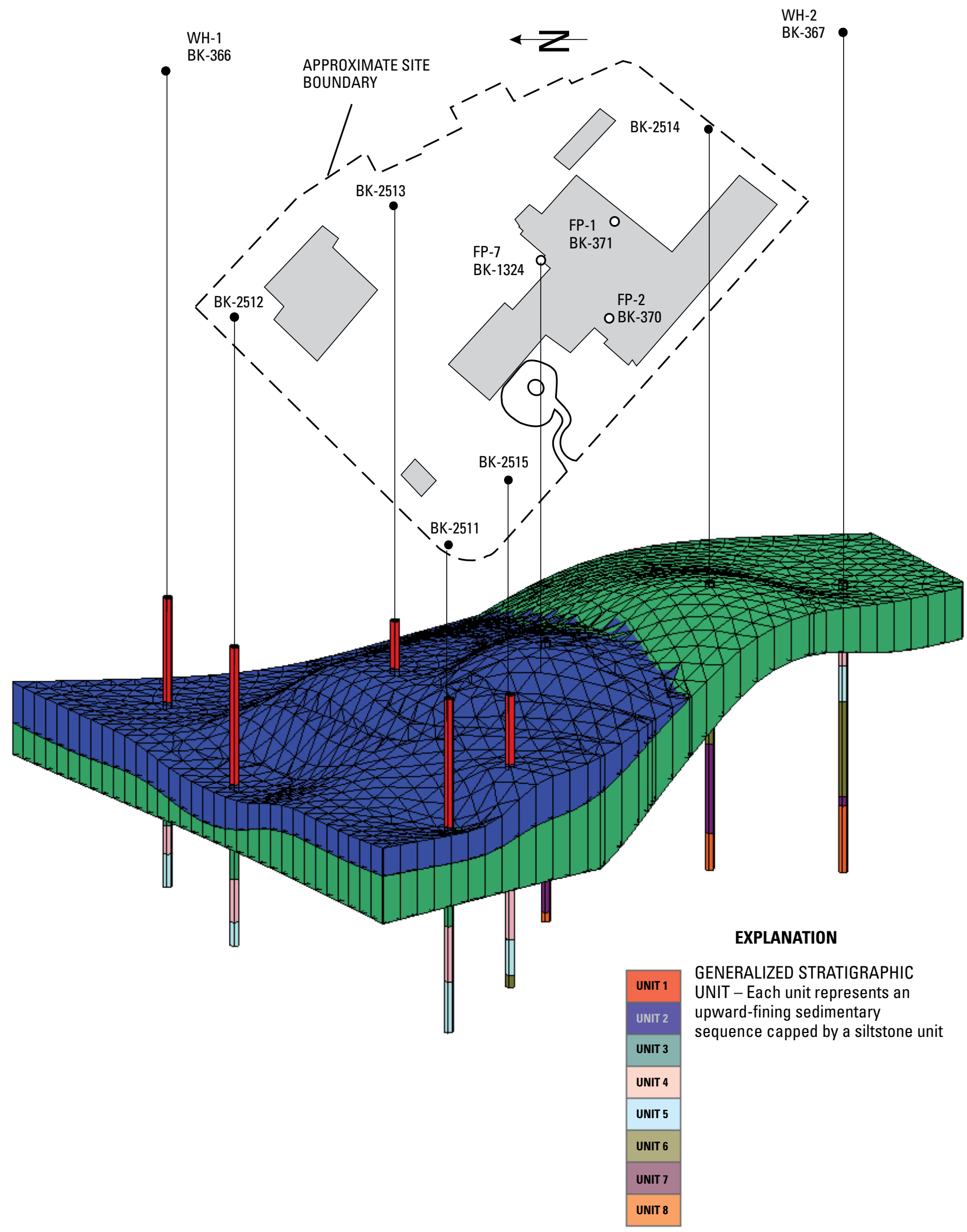

Figure 52. Location of stratigraphic units 2 and 3 at the Fischer and Porter Superfund Site, Warminster Township, Bucks County, Pennsylvania. 


\section{Summary and Conclusions}

The 38-acre Fischer and Porter Company Superfund Site is in Warminster Township, Bucks County, Pa. Historically, as part of the manufacturing process, trichloroethylene (TCE) degreasers were operated for parts cleaning. In 1979, the Bucks County Health Department detected TCE and other volatile organic compounds (VOCs) in water from the Fischer and Porter Site on-site supply wells and nearby publicsupply wells. The Fischer and Porter Site was designated as a Superfund Site and placed on the National Priorities List in September 1983. The U.S. Environmental Protection Agency (USEPA) requested the assistance of the U.S. Geological Survey (USGS) at the Fischer and Porter Site for the completion of the 5-year site review initiated in 2004. The purpose of this study was to describe changes in groundwater levels and VOC contaminant concentrations and migration caused by the shutdown of the Warminster Heights supply wells in 2004 and to delineate the off-site groundwater-contamination plume. As part of the current study, five additional off-site monitor wells were drilled and sampled. This study was done by the USGS in cooperation with the USEPA.

The Fischer and Porter Site and surrounding area are underlain by sedimentary rocks of the Stockton Formation of Late Triassic age. In the vicinity of the Fischer and Porter Site, the Stockton Formation strikes approximately N. $65^{\circ}$ E. and dips approximately $9^{\circ} \mathrm{NW}$. The rocks are chiefly interbedded arkosic sandstone and siltstone.

The rocks of the Stockton Formation form an aquifer system comprised of a series of gently dipping lithologic units with different hydraulic properties. The beds act as a series of alternating aquifers and confining or semiconfining units that form a leaky, multiaquifer system. Groundwater in the unweathered zone mainly moves through a network of interconnecting secondary openings - bedding-plane fractures and joints. Beds within the Stockton Formation are hydraulically connected by steeply dipping joints that cross each other at various angles. Groundwater generally is unconfined in the shallower part of the aquifer and confined or semiconfined in the deeper part of the aquifer. Boreholes may penetrate several major water-producing zones with different hydraulic properties and hydraulic heads. Where differences in head exist between water-producing zones, water in the borehole flows in the direction of decreasing head. Where the hydraulic head is greater than the altitude of the top of the well casing, the well will flow.

The three-dimensional lithostratigraphic model of the Fischer and Porter Site used in this report was developed by Sloto and others (1995) from lithostratigraphic interpretations and correlations based on the response to lithology of borehole geophysical logs collected in on-site boreholes. The lithostratigraphic model was extended off-site using borehole geophysical logs collected in five off-site boreholes drilled for this study. The lithostratigraphy was simplified by combining individual lithologic units into generalized sedimentary cycles.
These cycles were labeled and are called stratigraphic units in this report.

The shutdown of the Warminster Heights wells had little effect on the direction of groundwater flow in the shallow zone (from land surface to approximately $100 \mathrm{ft}$ below land surface). For this study, water levels were measured in shallow wells on September 15, 2006, January 16-20, 2007, and May 21-22, 2009. For all three measurement sets, the direction of groundwater flow was to the north-northwest, which is about the same direction shown on previous (1993-96) potentiometric-surface maps for the shallow zone. Horizontal gradients also remained about the same.

For intermediate-depth wells (from approximately 100 to $210 \mathrm{ft}$ below land surface), the direction of groundwater flow was to the northwest in 2006-09. This differs from the previously mapped groundwater-flow direction, which generally was to the north in 1993-96 when Warminster Heights well WH-1 was pumping. The direction of groundwater flow in the intermediate-depth zone, which was influenced by the pumping of well WH-1, shifted from the north to the northwest and the horizontal hydraulic gradient became slightly steeper after well WH-1 stopped pumping.

For deep wells (greater than approximately $210 \mathrm{ft}$ below land surface), the direction of groundwater flow was to the northwest in 2007-09. The direction of groundwater flow in the deep zone was to the west and southwest in 1993-94 and to the northeast in 1996 toward well WH-1. After well WH-1 stopped pumping, the direction of groundwater flow shifted to the northwest. The horizontal hydraulic gradient in the deep zone has remained fairly flat on the northwestern side of the site.

Differences in water levels among the shallow, intermediate, and deep wells at each monitor-well cluster indicate the presence of vertical head gradients. Along section D-C, which is approximately parallel to the southwestern site boundary, when the Fisher and Porter remediation wells and Warminster Heights wells were pumping, the vertical head gradient was downward at all monitor-well clusters. Groundwater flow through stratigraphic unit 3 was toward the remediation wells. When the Warminster Heights wells were pumping and the Fisher and Porter remediation wells were not pumping, the vertical head gradient was downward at all monitor-well clusters, and flow in stratigraphic unit 3 was away from the remediation wells. Along section D-E, which is approximately along strike at the northwestern boundary of the Fischer and Porter Site, groundwater flow was from south to north with a downward vertical hydraulic gradient when the Warminster Heights wells were pumping. After the Warminster Heights wells stopped pumping, groundwater flow was still from south to north; however, the vertical hydraulic gradient between the deep and the intermediate zone was upward instead of downward.

In 2007, TCE concentrations measured by the USGS in water samples from the three remediation wells ranged from less than 340 to 3,000 micrograms per liter $(\mu \mathrm{g} / \mathrm{L})$, and PCE concentrations ranged from less than 8.4 to $51 \mu \mathrm{g} / \mathrm{L}$. TCE 
concentrations have decreased with time but remained highly variable. From August 1997 to June 2001, the TCE and PCE concentrations in water samples from wells BK-370 and BK-371 showed an increasing trend, and from June 2001 to September 2008 showed a decreasing trend. TCE and PCE concentrations in water samples from well BK-1324 showed a decreasing trend over the same time period.

In 2007, TCE concentrations measured in water samples from wells completed in the shallow zone ranged from less than 0.1 to $14,000 \mu \mathrm{g} / \mathrm{L}$, and PCE concentrations ranged from less than 0.1 to $340 \mu \mathrm{g} / \mathrm{L}$. The highest TCE and PCE concentrations were in a water sample from well BK-2811, which is near the source area. The TCE and PCE plume extended offsite to the north of the source area. The migration of the plume was consistent with the hydraulic gradient in the shallow zone. Concentrations of TCE in water samples from well BK-2525 east of the source area decreased from 8 to $3.9 \mu \mathrm{g} / \mathrm{L}$ from 1996 to 2007. Concentrations of TCE in water samples from well BK-2528 west of the source area increased from 4 to $9.3 \mu \mathrm{g} / \mathrm{L}$ from 1996 to 2007. Concentrations of PCE in water samples from well BK-2827 east of the source area increased from less than 10 to $23 \mu \mathrm{g} / \mathrm{L}$ from 1996 to 2007 .

VOC concentrations in water samples from off-site monitor wells BK-3042, BK-3043, BK-3045, and BK-3046 were included with the on-site intermediate-depth wells because they are screened in the same lithostratigraphic units as the on-site intermediate-depth wells. For 2007-09, TCE concentrations measured in water samples from on-site intermediatedepth monitor wells ranged from less than 0.1 to $500 \mu \mathrm{g} / \mathrm{L}$, and PCE concentrations ranged from 1.3 to $28 \mu \mathrm{g} / \mathrm{L}$. The highest TCE and PCE concentrations were in water samples from the downgradient monitor well BK-2522. The TCE and PCE plumes extended off-site to the north and northwest of the source area. The plumes followed the hydraulic gradient in the intermediate zone. Concentrations of TCE in water samples from wells BK-2524 and BK-2810 east of the source area decreased from 55 to $4.4 \mu \mathrm{g} / \mathrm{L}$ and 720 to $37 \mu \mathrm{g} / \mathrm{L}$, respectively, from 1996 to 2007. Concentrations of TCE in water samples north (BK-2522) and west (BK-2521 and BK-2527) of the source area increased from 390 to $500 \mu \mathrm{g} / \mathrm{L}$, 52 to $100 \mu \mathrm{g} / \mathrm{L}$, and 210 to $240 \mu \mathrm{g} / \mathrm{L}$, respectively, from 1996 to 2007. Concentrations of PCE in water samples from wells from 1996 to 2007 were variable.

In 2007, the TCE concentrations measured in water samples from on-site monitor wells completed in the deep zone ranged from 1.1 to $86 \mu \mathrm{g} / \mathrm{L}$, and PCE concentrations ranged from 0.2 to $8.4 \mu \mathrm{g} / \mathrm{L}$. TCE and PCE were detected in every deep well sampled. The highest concentrations of TCE and PCE were in water samples from downgradient monitor well BK-2512. The TCE and PCE plumes extended off-site to the northwest of the source area and generally followed the hydraulic gradient in the deep zone. Well BK-3034, which was flowing in 2007, may have influenced groundwater flow and movement of TCE and PCE in the deep zone. In general, concentrations of TCE in water samples for monitor wells outside the source area increased between 1996 and 2005 and decreased between 2005 and 2007; concentrations were less in 2007 than in 1996. Concentrations of PCE in water samples for monitor wells outside the source area were less than $10 \mu \mathrm{g} / \mathrm{L}$ in 2007.

In 2007, the vinyl chloride concentration measured in groundwater samples from all wells ranged from less than 0.2 to $5,000 \mu \mathrm{g} / \mathrm{L}$. The presence of vinyl chloride indicated that reductive dehalogenation of TCE and PCE was occurring.

For wells along section A-C, which is approximately parallel to the southwestern site boundary, the highest TCE and PCE concentrations away from the source area were measured in water samples from wells BK-2521 and BK-2527, which are screened in stratigraphic unit 3. TCE and PCE appeared to be moving downdip though stratigraphic unit 3 . The downdip extent of TCE and PCE migration extended approximately $550 \mathrm{ft}$ off-site to the northwest and $750 \mathrm{ft}$ off-site to the north. TCE concentrations in water samples from wells BK-2521 and BK-2527 increased from 52 to $100 \mu \mathrm{g} / \mathrm{L}$ and 210 to $240 \mu \mathrm{g} / \mathrm{L}$, respectively, from 1996 to 2007. For wells along section $\mathrm{B}-\mathrm{C}$, which is approximately parallel to the northeastern site boundary, the highest concentrations of TCE away from the source area were in water samples from wells BK-2522 and BK-2524, which are screened in stratigraphic units 2 and 3 . The highest PCE concentration $(28 \mu \mathrm{g} / \mathrm{L})$ measured away from the source area was in a water sample from well BK-2522, which is screened in stratigraphic units 2 and 3. TCE and PCE appeared to be moving downward and laterally though stratigraphic units 2,3 , and 4 .

The migration of VOCs from the Fischer and Porter Site source area is influenced by geologic and hydrologic controls. The hydrologic controls have changed with time. The wells at and in the vicinity of the Fischer and Porter Site were initially sampled in 1979-80. TCE concentrations were as high as $87,000 \mu \mathrm{g} / \mathrm{L}$ on-site and $350 \mu \mathrm{g} / \mathrm{L}$ off-site. At that time, three public-supply wells (BK-366, BK-367, and MG-946) and three industrial-supply wells (BK-368, BK-370, and BK-371) were pumping. Groundwater contaminated with VOCs flowed downdip and then northeast along strike toward well BK-366, downdip toward well BK-368, and downdip and then west along strike toward well MG-946.

Sometime between 1980 and 1990, wells BK-368 and MG-946 stopped pumping and were abandoned. In 1984, the Fischer and Porter supply wells BK-370 and BK-371, along with monitor well BK-1731, became remediation wells pumped continuously at a combined rate of 75 gallons per minute. The Warminster Heights wells continued to pump until 2004. The direction of groundwater flow in the intermediate and deep zones was influenced by the pumping of well WH-1. Potentiometric-surface maps for 1986 showed groundwater flow to the north toward well WH-1. In 1993, additional monitor wells were drilled at the Fischer and Porter Site by the USGS. For the intermediate-depth wells, the groundwater-flow direction in 1993-96 generally was to the north when well WH-1 was pumping. For deep wells, the direction of groundwater flow was to the west and southwest in 1993-94 and to the northeast toward well WH-1 in 1996. After well WH-1 
stopped pumping in 2004, the direction of groundwater flow in the intermediate zone shifted from the north to the northwest. In the deep zone, the direction of groundwater flow also shifted to the northwest.

The movement of VOCs from the Fischer and Porter Site may have been influenced by well BK-3034. In 2007, this unused 300-ft deep open-hole well was flowing at an estimated 20-30 gallons per minute. When flowing, the well acted as a withdrawal well. The well was abandoned (grouted closed) in 2008.

Stratigraphic units 2 and 3 crop out beneath the former Fischer and Porter plant. VOCs originating at the plant entered these stratigraphic units and moved downdip. The plume then spread out laterally along strike in response to pumping of public-supply wells. The long axis of the plume is oriented about N. $18^{\circ} \mathrm{W}$. in the direction of dip. This direction also coincides with the predominant joint set in the Stockton Formation (N. $25^{\circ}$ W.) and is the direction of the hydraulic gradient in the intermediate and deep zones. The leading edge of the plume spread laterally under hydraulic gradients created by the pumping of public-supply wells MG-946 and BK-366. In 1979-80, the leading edge of the plume was about $3,500 \mathrm{ft}$ wide. With the cessation of pumping and the biodegradation of TCE, the size of the plume decreased. In 2007-09, the plume was approximately 2,000 ft long and 2,000 ft wide at the leading edge.

\section{Acknowledgments}

Permission from property owners to drill and test the additional off-site monitor wells is greatly appreciated. Access to wells for water-level measurements and samples was provided by John Engle of ABB, Inc.; Carol Gross; HavisShields, Inc.; and the Warminster Municipal Authority (Timothy Hagey and Philip Gardener). Assistance with groundwater sampling was provided by Leif Olson and Philip Bird of the USGS and Richard Sacks of Sigma Environmental Services, Inc. Borehole geophysical logging was done by Randall Conger of the USGS. Borehole television surveys were made by Philip Bird. Aquifer-isolation tests were conducted by Leif Olson, Randall Conger, and Philip Bird.

\section{References Cited}

BCM, Inc., 1986, Hydrogeological report for Fischer and Porter Company, Warminster, Pennsylvania: Plymouth Meeting, Pa., variously paginated.

CH2M Hill, Inc., 1998, Fischer and Porter Site remedial investigation report: Parsippany, N.J., variously paginated.
Keys, W.S., 1990, Borehole geophysics applied to groundwater investigations: U.S. Geological Survey Techniques of Water-Resources Investigations, book 2, chap. E-2, 149 p.

Rima, D.R., Meisler, Harold, and Longwill, Stanley, 1962, Geology and hydrology of the Stockton Formation in southeastern Pennsylvania: Pennsylvania Geologic Survey, 4th ser., Water Resources Report 14, 111 p.

Sims, J.L., Suflita, J.M., and Russell, H.H., 1991, Reductive dehalogenation of organic contaminants in soils and ground water: U.S. Environmental Protection Agency EPA/540/490/054, 12 p.

Sloto, R.A., and Davis, D.K., 1983, Effect of urbanization on the water resources of Warminster Township, Bucks County, Pennsylvania: U.S. Geological Survey Water-Resources Investigations Report 82-4020, 72 p.

Sloto, R.A., Macchiaroli, Paola, and Conger, R.W., 1995, Geohydrology and vertical distribution of volatile organic compounds in ground water, Fischer and Porter Company Superfund Site, Warminster, Bucks County, Pennsylvania: U.S. Geological Survey Water-Resources Investigations Report 95-4220, 137 p.

Sloto, R.A., Macchiaroli, Paola, and Towle, M.T., 1992, Identification of a multiaquifer ground-water cross-contamination problem in the Stockton Formation by use of borehole geophysical methods, Hatboro, Pennsylvania: Proceedings, Symposium on the Application of Geophysics to Engineering and Environmental Problems, Oakbrook, Illinois, April 26-29, 1992, Society of Engineering and Mineral Exploration Geophysicists, p. 21-35.

Sloto, R.A., Macchiaroli, Paola, and Towle, M.T., 1996, Geohydrology of the Stockton Formation and cross-contamination through open boreholes, Hatboro Borough and Warminster Township, Pennsylvania: U.S. Geological Survey Water-Resources Investigations Report 96-4047, 49 p.

SMC Martin, Inc., 1980, Hydrogeological study of Fischer and Porter company and vicinity, Warminster Township, Bucks County, Pennsylvania: King of Prussia, Pa., variously paginated.

Tetra Tech EM, Inc., 2005, Trip report for the Fischer and Porter Co. Site Warminster, Bucks County, Pennsylvania: Boothwyn, Pa., 17 p. 


\section{Appendix 1. Chemical Analyses}

Table 1-1. Selected water-quality constituents measured in the field in water samples, Fischer and Porter Superfund Site, Warminster Township, Bucks County, Pennsylvania.

[mg/L, milligrams per liter; $\mathrm{C}$, Celsius; $\mu \mathrm{S} / \mathrm{cm}$ at $25^{\circ} \mathrm{C}$, microsiemens per centimeter at 25 degrees Celsius]

\begin{tabular}{|c|c|c|c|c|c|c|}
\hline $\begin{array}{l}\text { USGS well- } \\
\text { identification } \\
\text { number }\end{array}$ & Sample date & $\begin{array}{l}\text { Site well- } \\
\text { identification } \\
\text { number }\end{array}$ & $\begin{array}{c}\mathrm{pH} \\
\text { (standard units) }\end{array}$ & $\begin{array}{l}\text { Dissolved oxygen } \\
\text { (mg/L) }\end{array}$ & $\begin{array}{c}\text { Temperature } \\
\left({ }^{\circ} \mathrm{C}\right)\end{array}$ & $\begin{array}{c}\text { Specific } \\
\text { conductance } \\
\left(\mu \mathrm{S} / \mathrm{cm} \text { at } 25^{\circ} \mathrm{C}\right)\end{array}$ \\
\hline BK-366 & $3 / 37 / 2007$ & WH-1 & 7.4 & 4.0 & 14.3 & 639 \\
\hline BK-367 & $2 / 22 / 2007$ & WH-2 & 6.8 & 8.5 & 14.8 & 550 \\
\hline BK-1030 & $2 / 22 / 2007$ & WMA 7S & 6.8 & 2.9 & 13.9 & 514 \\
\hline BK-1731 & $1 / 16 / 2007$ & & 6.5 & .6 & 14.9 & 918 \\
\hline BK-1793 & $1 / 17 / 2007$ & FP-5 & 6.6 & 9.0 & 14.1 & 1,787 \\
\hline BK-2511 & $1 / 16 / 2007$ & & 8.1 & 3.1 & 13.3 & 266 \\
\hline BK-2512 & $1 / 18 / 2007$ & & 7.6 & .6 & 12.4 & 600 \\
\hline BK-2513 & $1 / 17 / 2007$ & & 7.8 & .6 & 12.2 & 371 \\
\hline BK-2514 & $1 / 16 / 2007$ & & 7.7 & 6.3 & 11.1 & 478 \\
\hline BK-2515 & $1 / 17 / 2007$ & & 8.8 & .8 & 12.7 & 340 \\
\hline BK-2521 & $1 / 18 / 2007$ & & 7.7 & 1.5 & 13.7 & 638 \\
\hline BK-2522 & $1 / 18 / 2007$ & & 7.2 & .2 & 12.8 & 800 \\
\hline BK-2523 & $1 / 18 / 2007$ & & 6.1 & 3.2 & 13.3 & 835 \\
\hline BK-2524 & $1 / 17 / 2007$ & & 6.9 & 7.5 & 12.2 & 637 \\
\hline BK-2525 & $1 / 17 / 2007$ & & 5.9 & 3.0 & 13.1 & 1,741 \\
\hline BK-2526 & $1 / 16 / 2007$ & & 6.2 & 7.0 & 12.3 & 478 \\
\hline BK-2527 & $1 / 18 / 2007$ & & 7.9 & .3 & 13.8 & 599 \\
\hline BK-2528 & $1 / 18 / 2007$ & & 5.8 & 5.1 & 15.2 & 1,253 \\
\hline BK-2810 & $1 / 19 / 2007$ & PH-1 & 6.6 & .5 & 14.5 & 1,005 \\
\hline BK-2811 & $1 / 19 / 2007$ & PH-2 & 6.6 & .7 & 13.2 & 1,916 \\
\hline BK-2827 & $1 / 17 / 2007$ & PH-4 & 6.5 & 6.4 & 15.9 & 2,670 \\
\hline
\end{tabular}




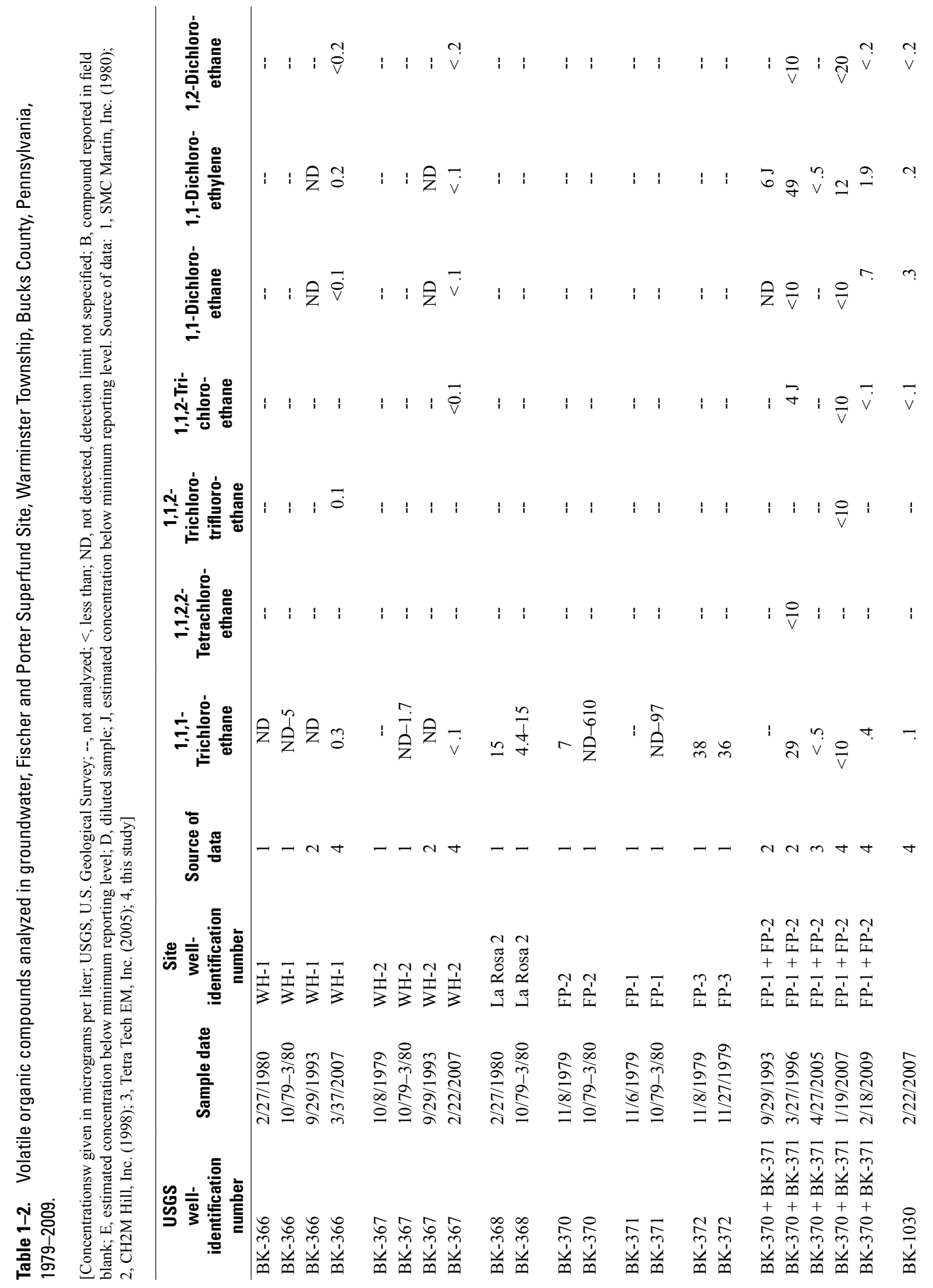




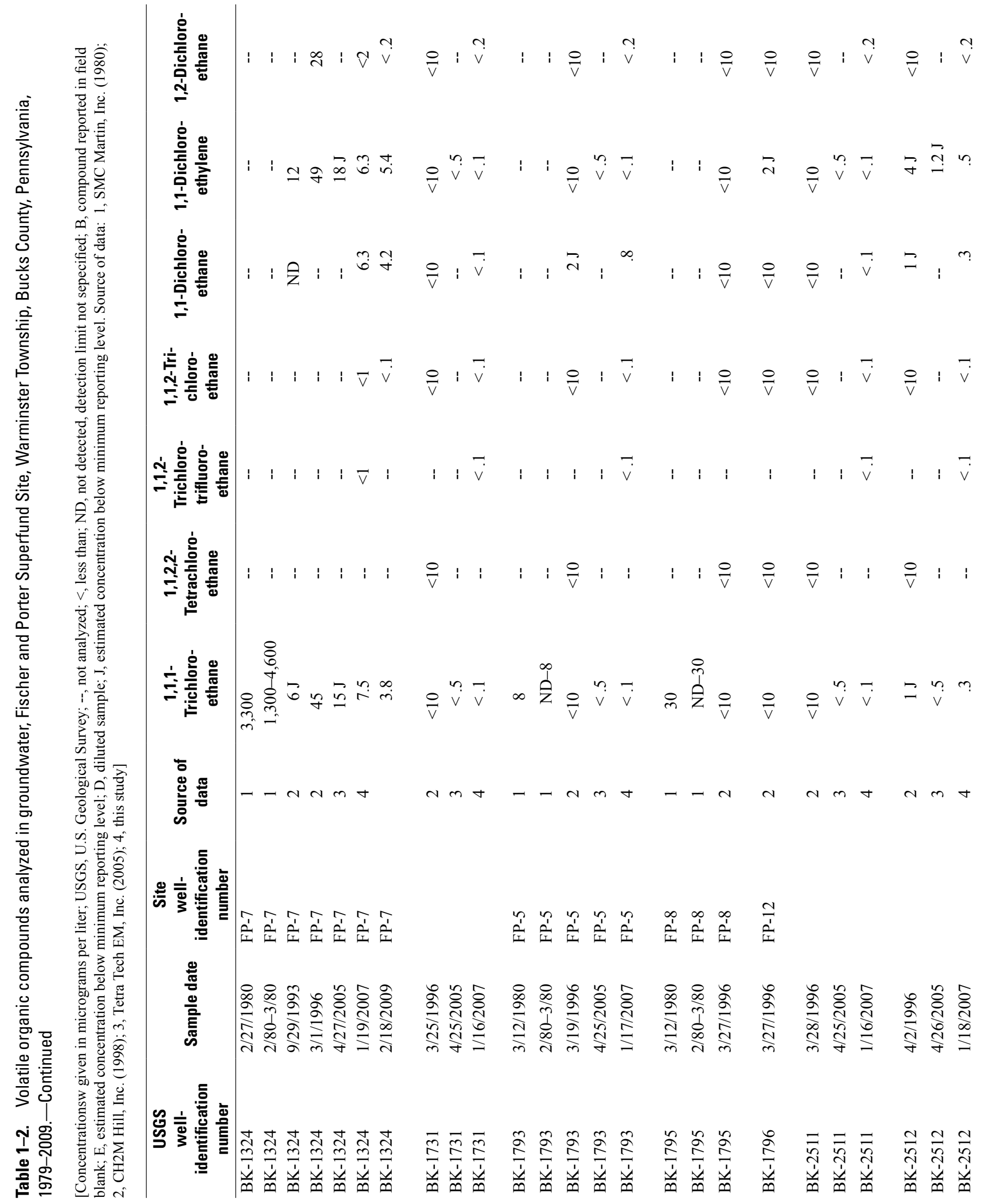




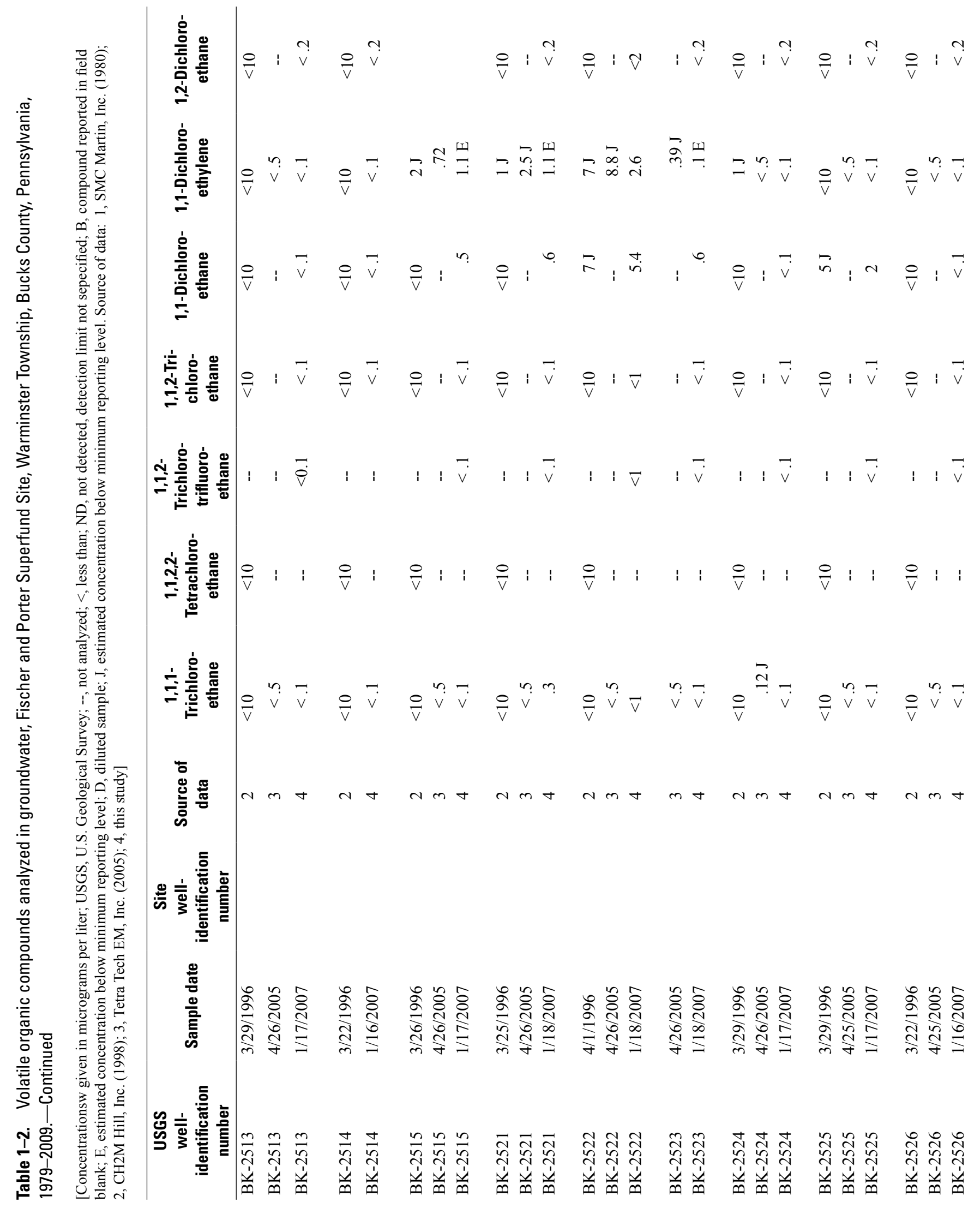




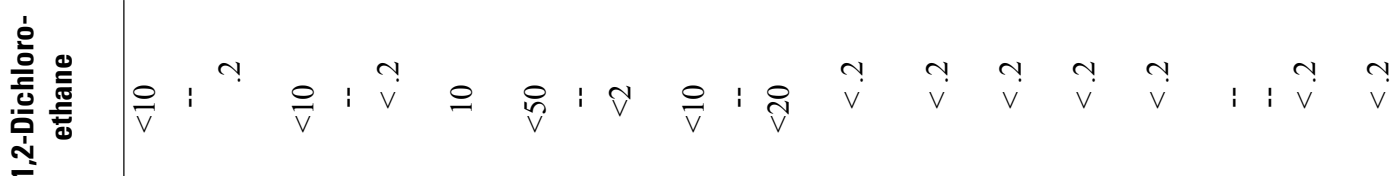

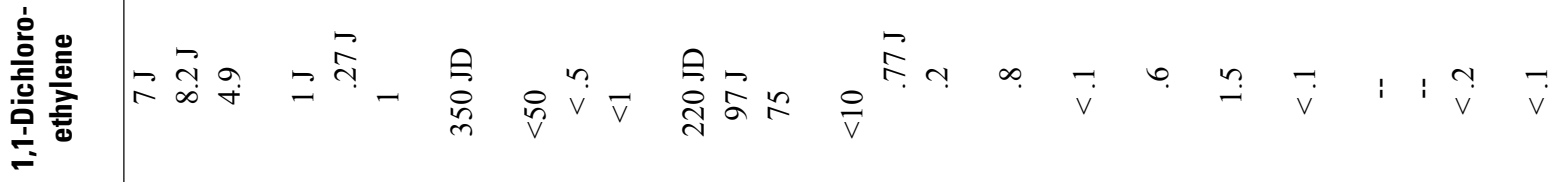

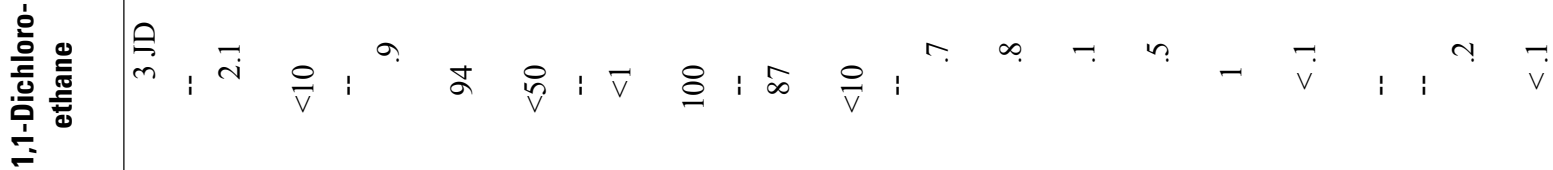

突

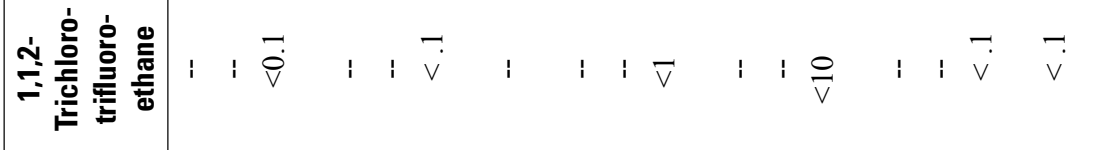

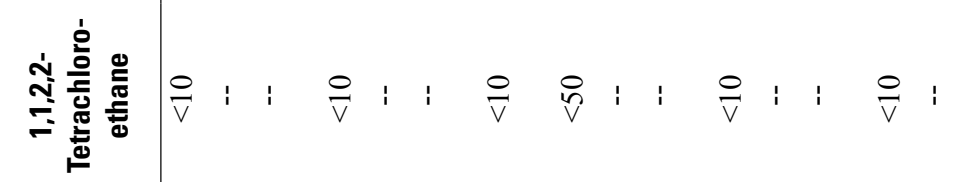

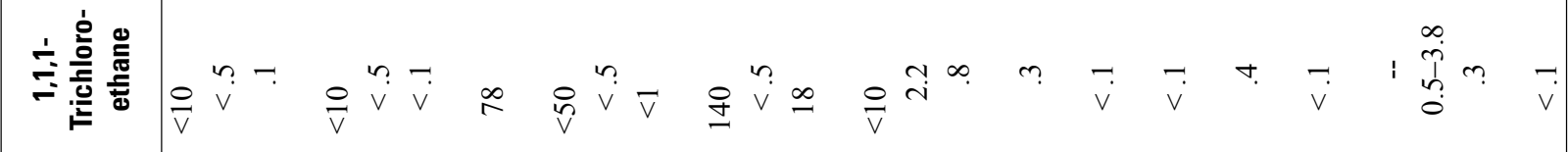

党

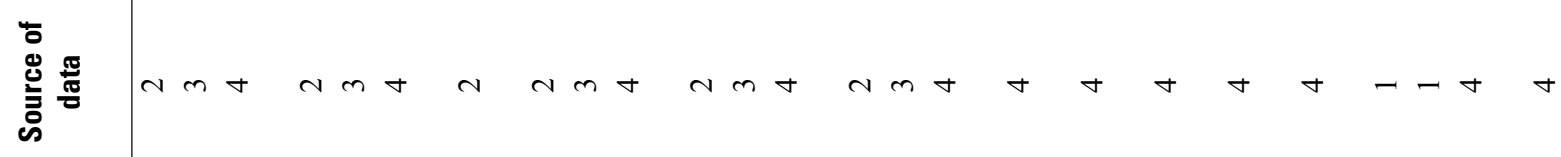



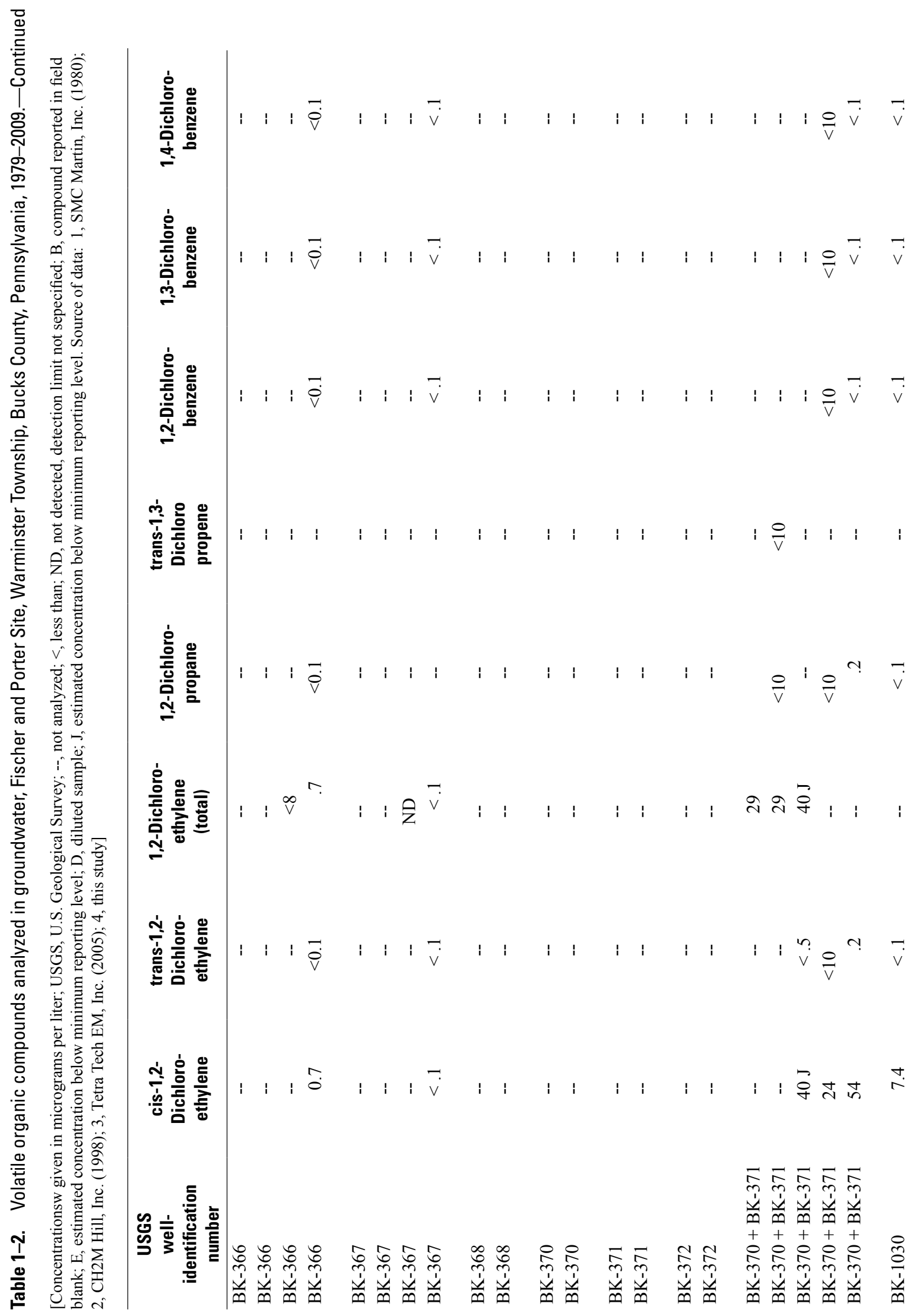

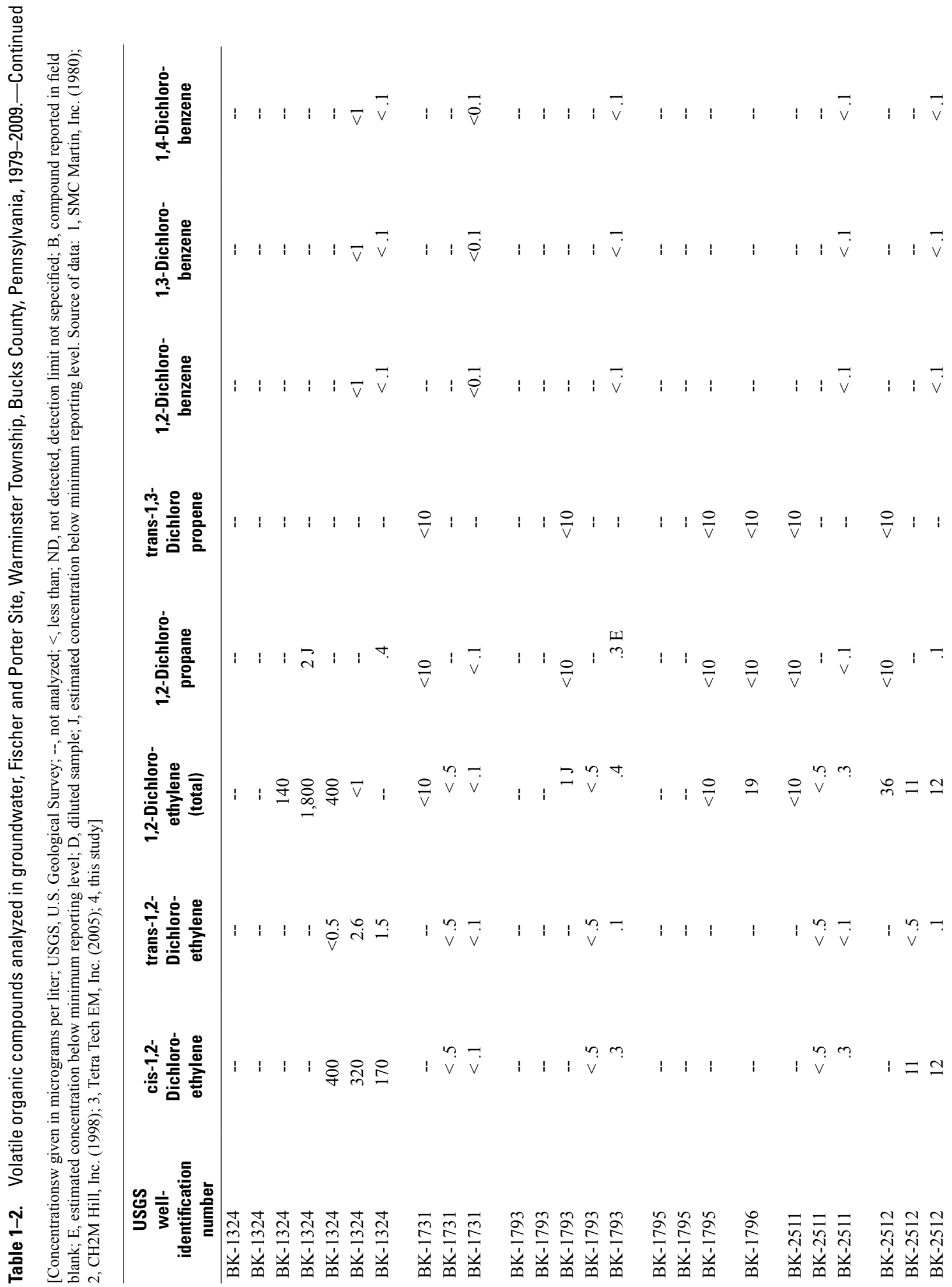

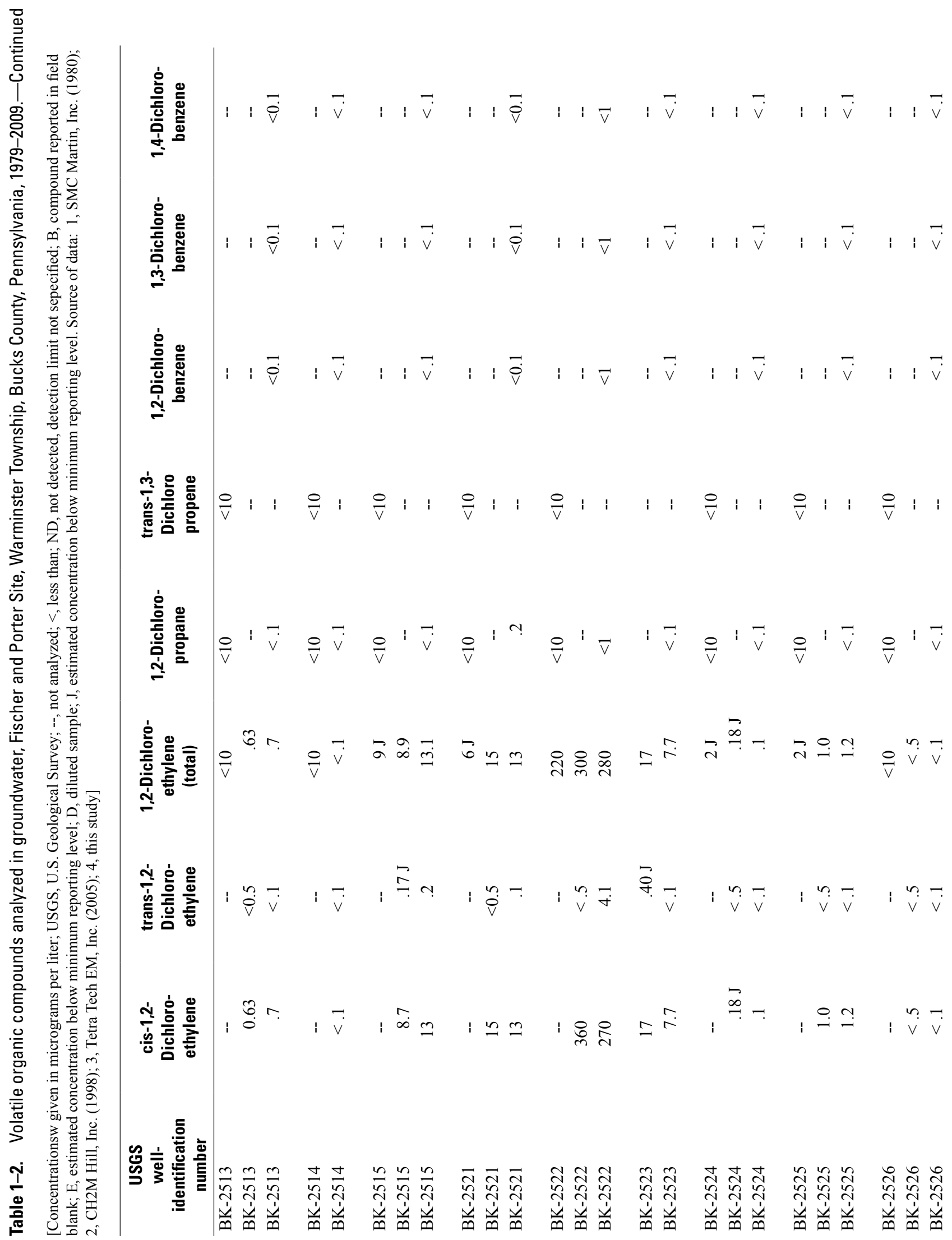


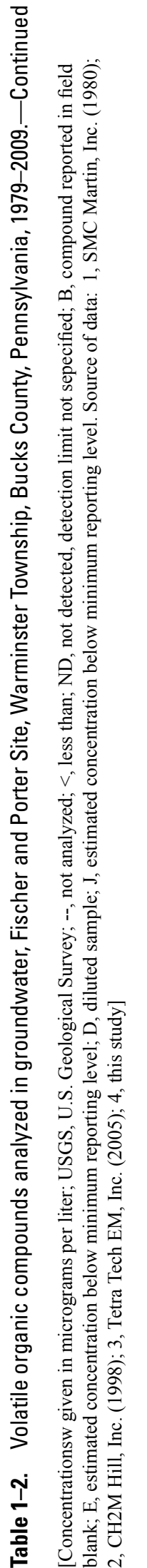

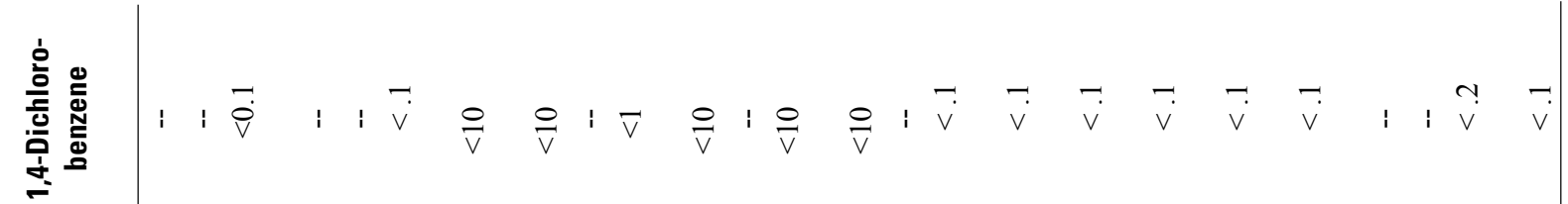

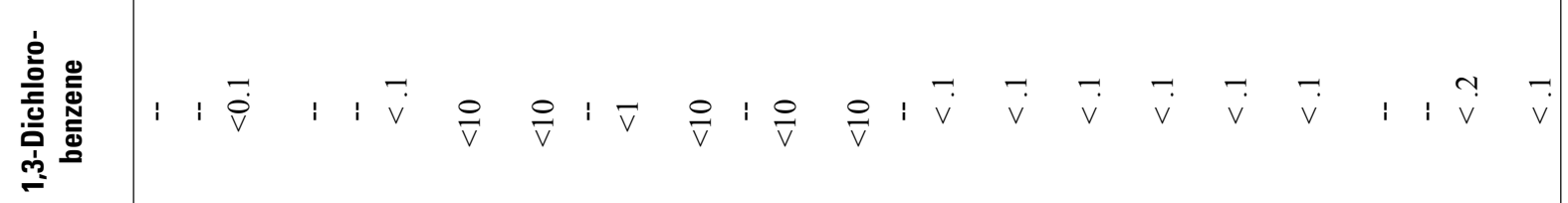

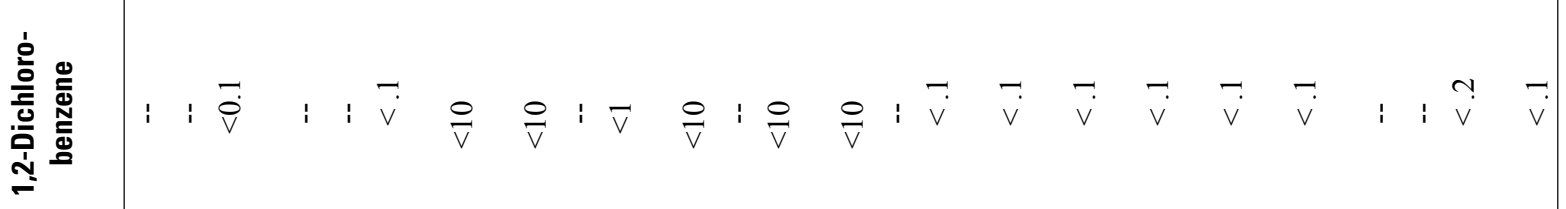

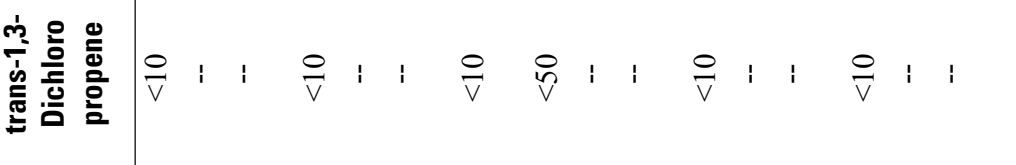

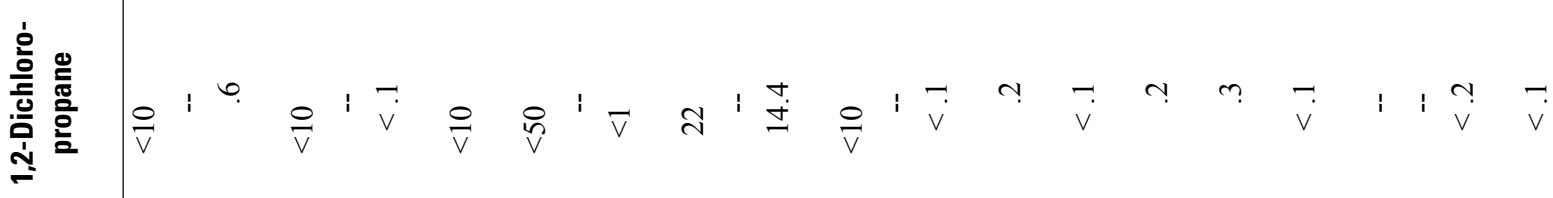

$$
\begin{aligned}
& \text { 产紊 }
\end{aligned}
$$

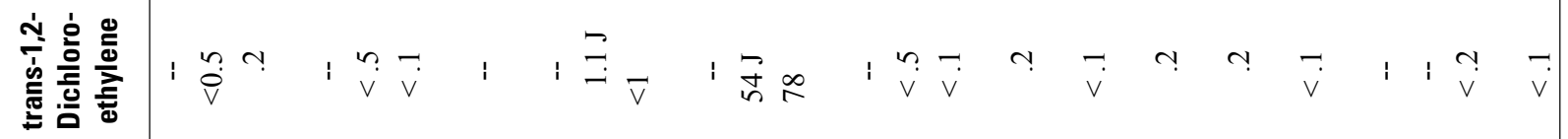

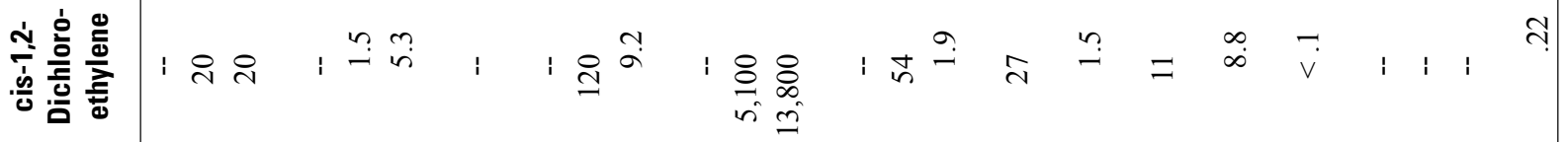

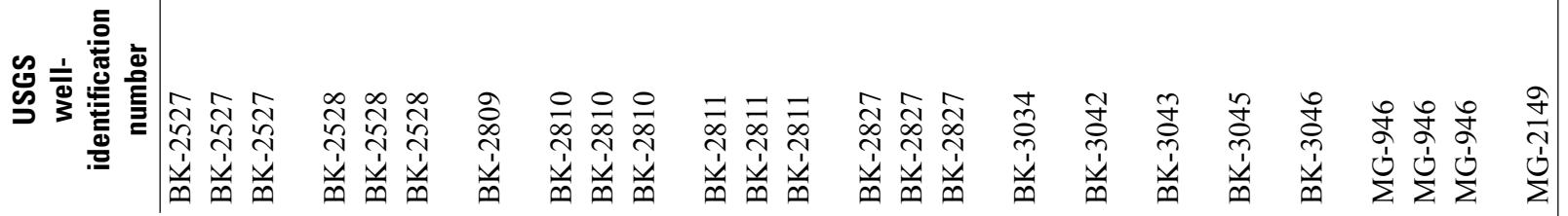




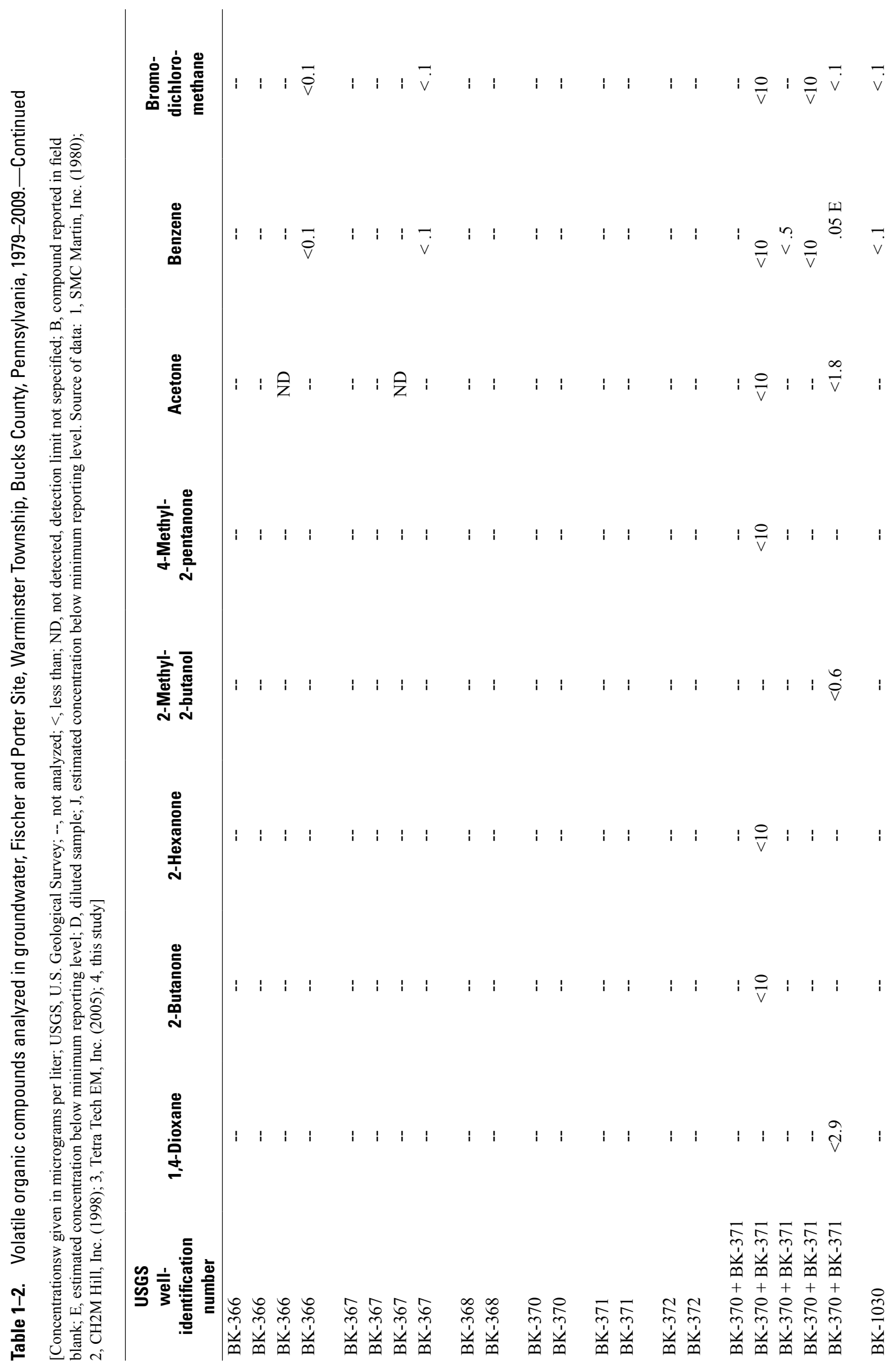



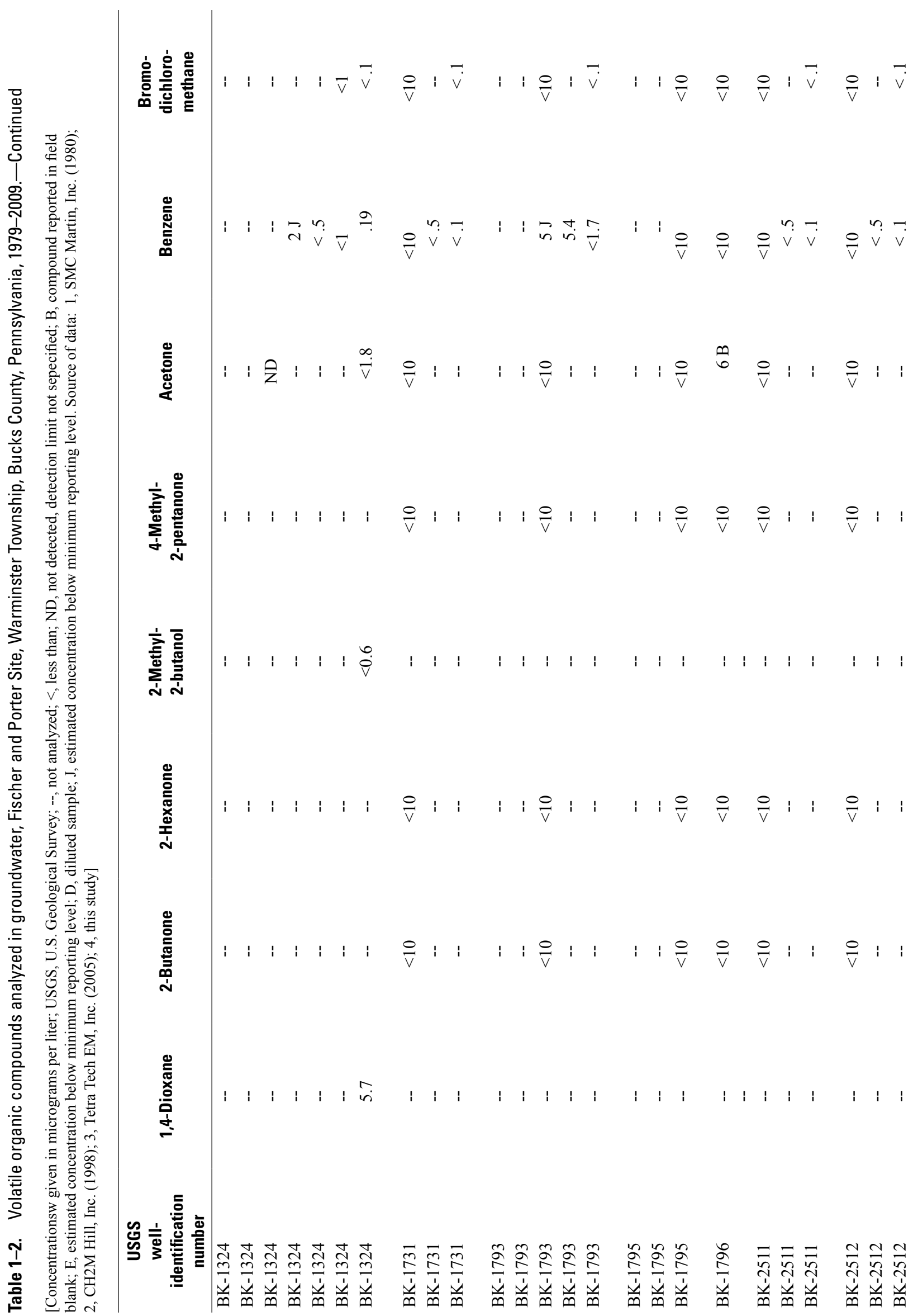

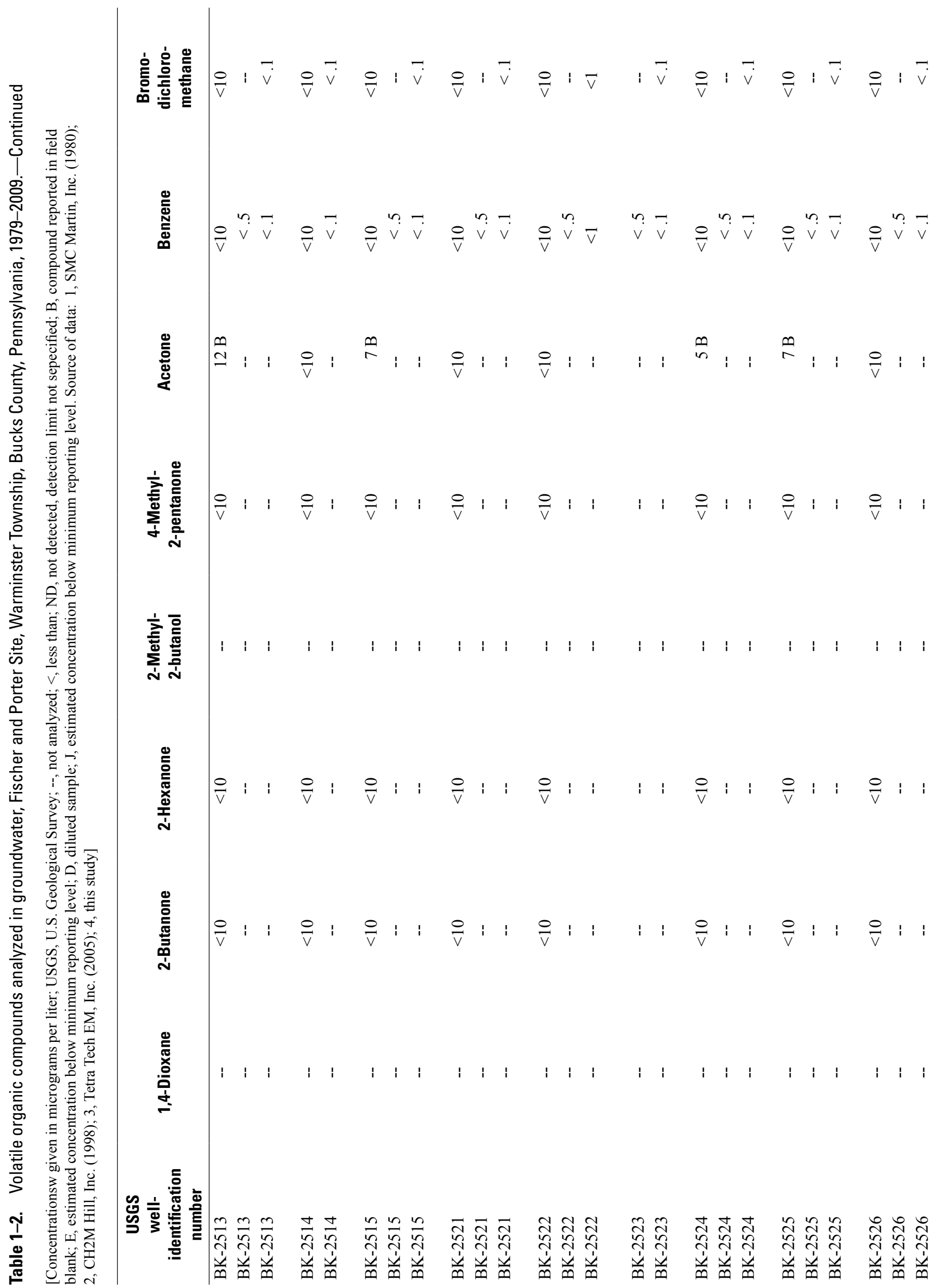

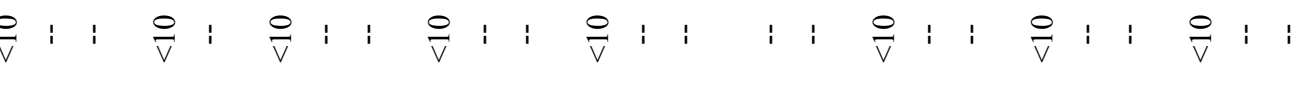

$\stackrel{9}{\sim}$

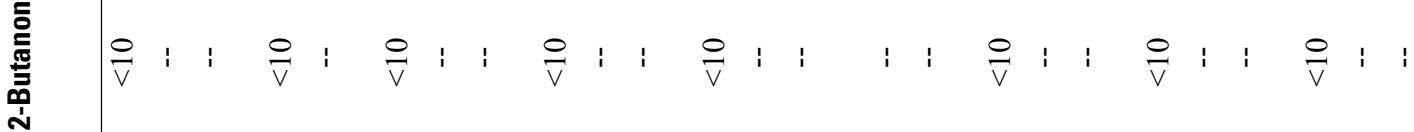




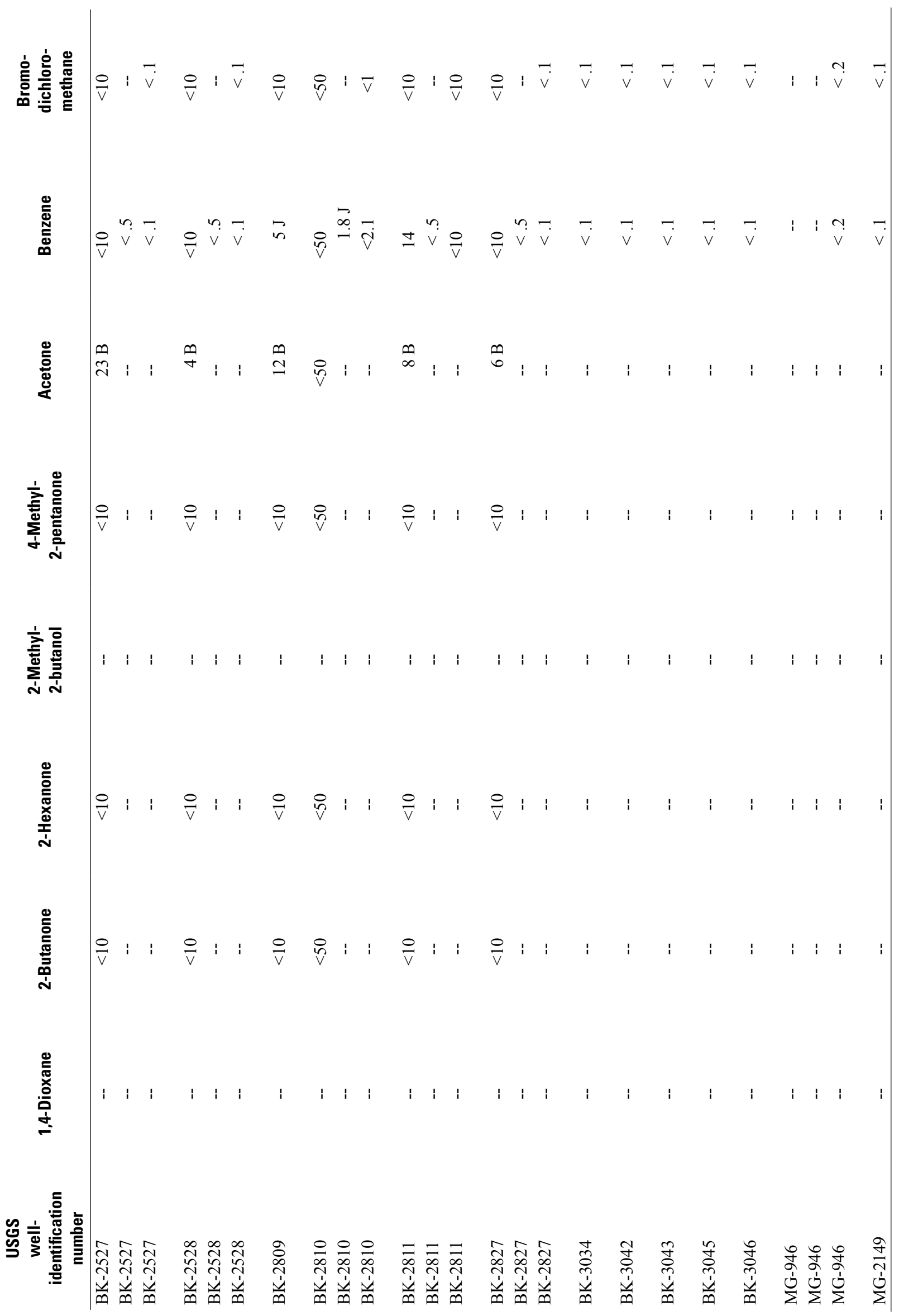



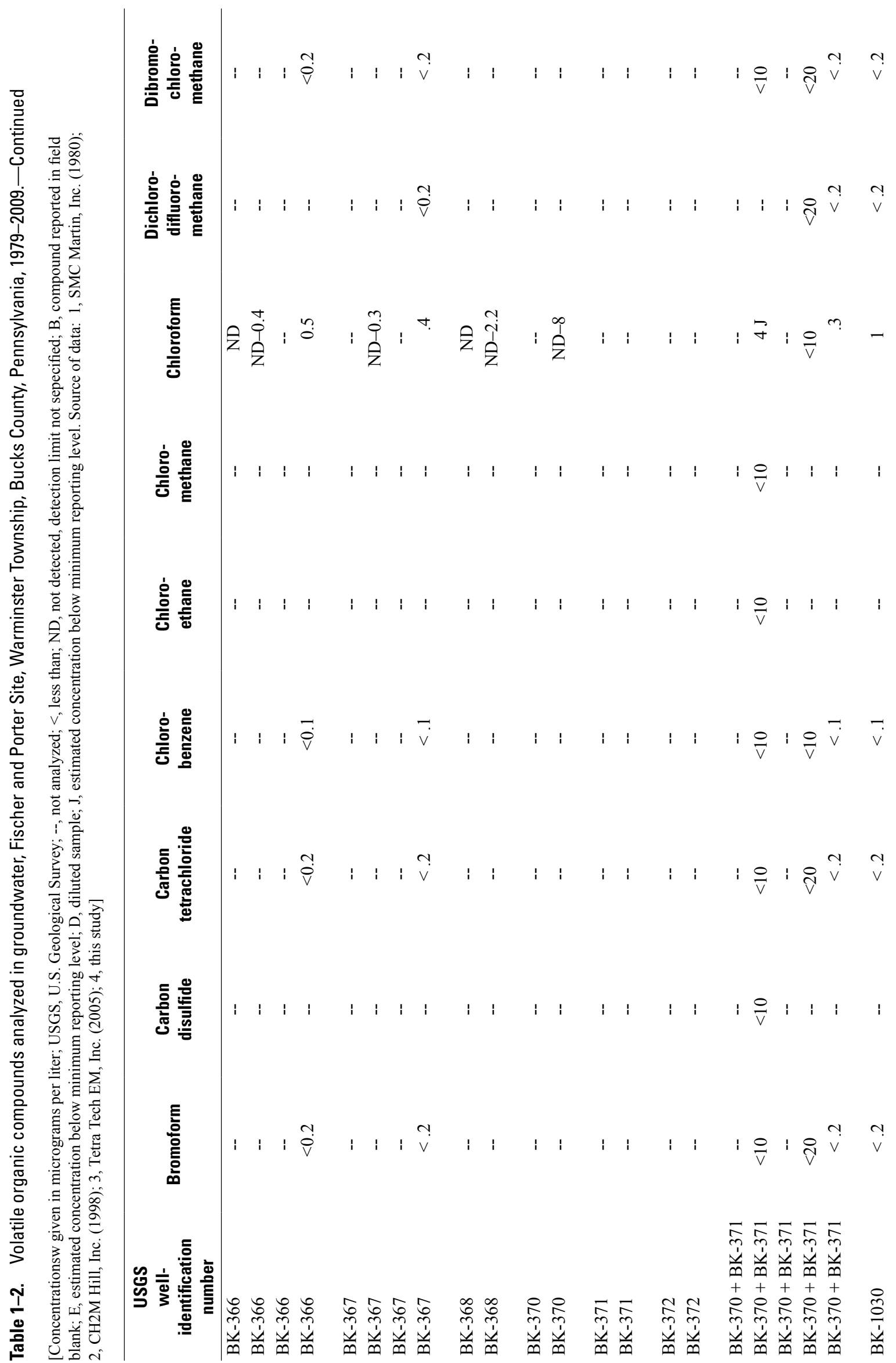


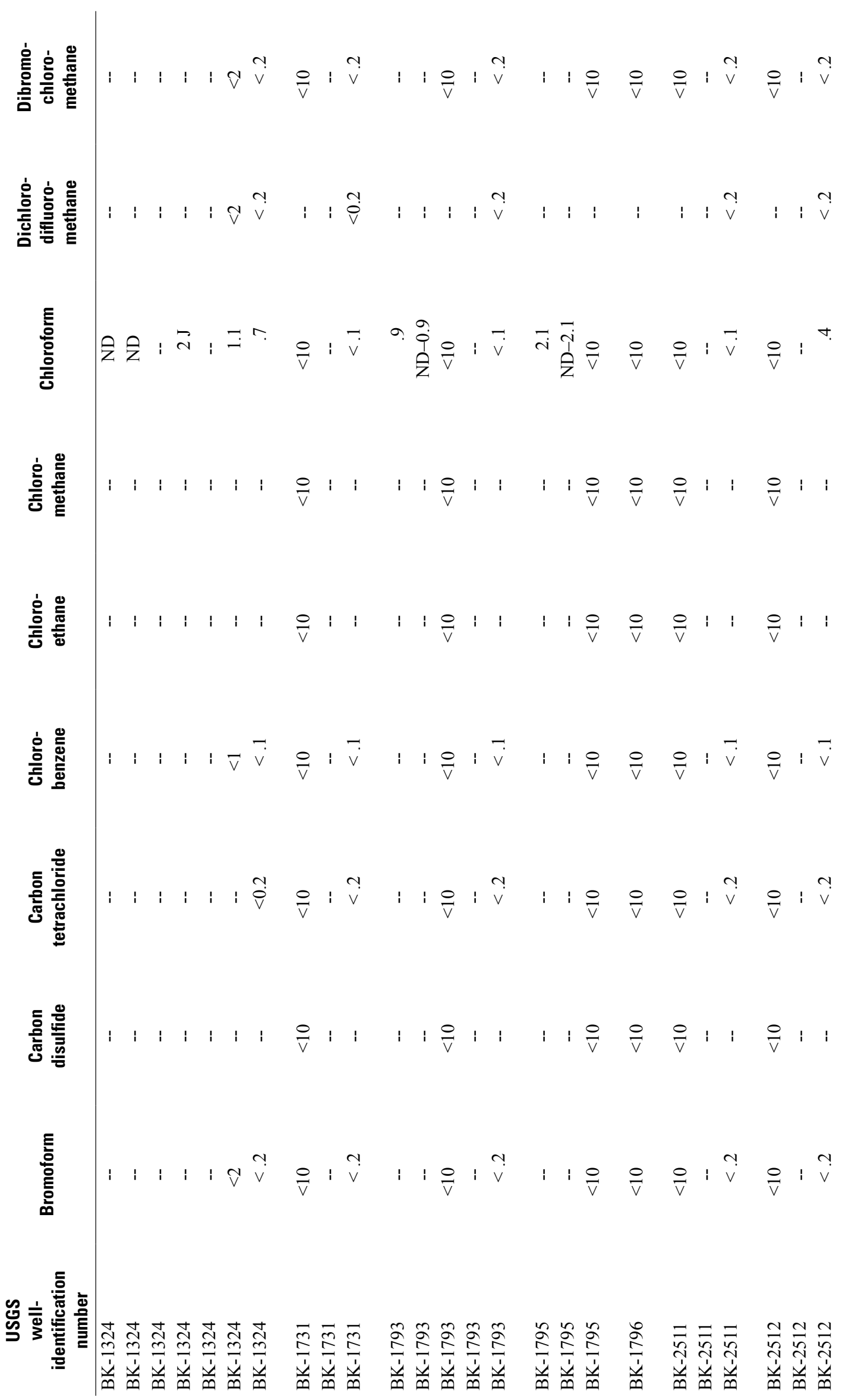




$$
\text { 旁 }
$$

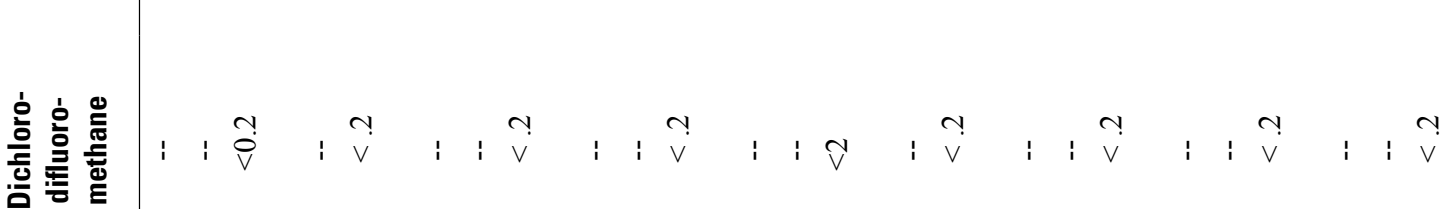

$$
1, \ldots, n, \cdots, n
$$$$
\text { 立党 }
$$

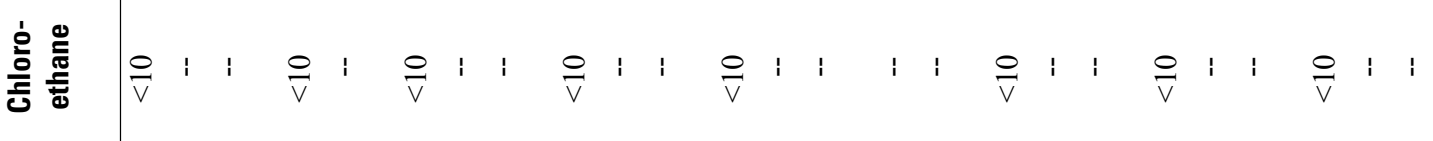$$
\text { 인 }
$$

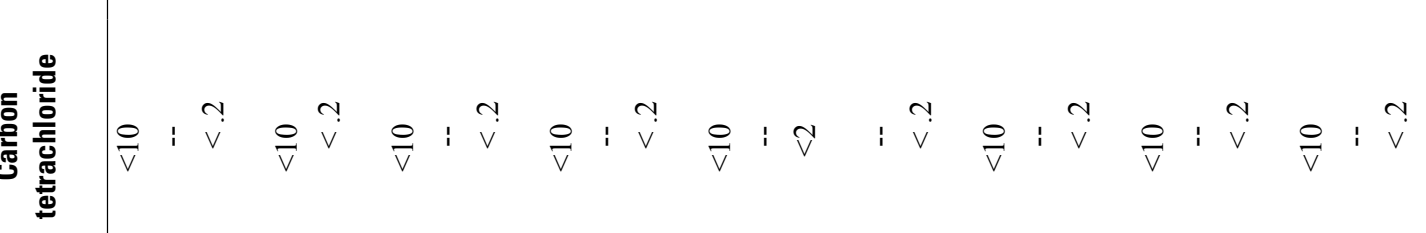$$
\text { 혼 }
$$

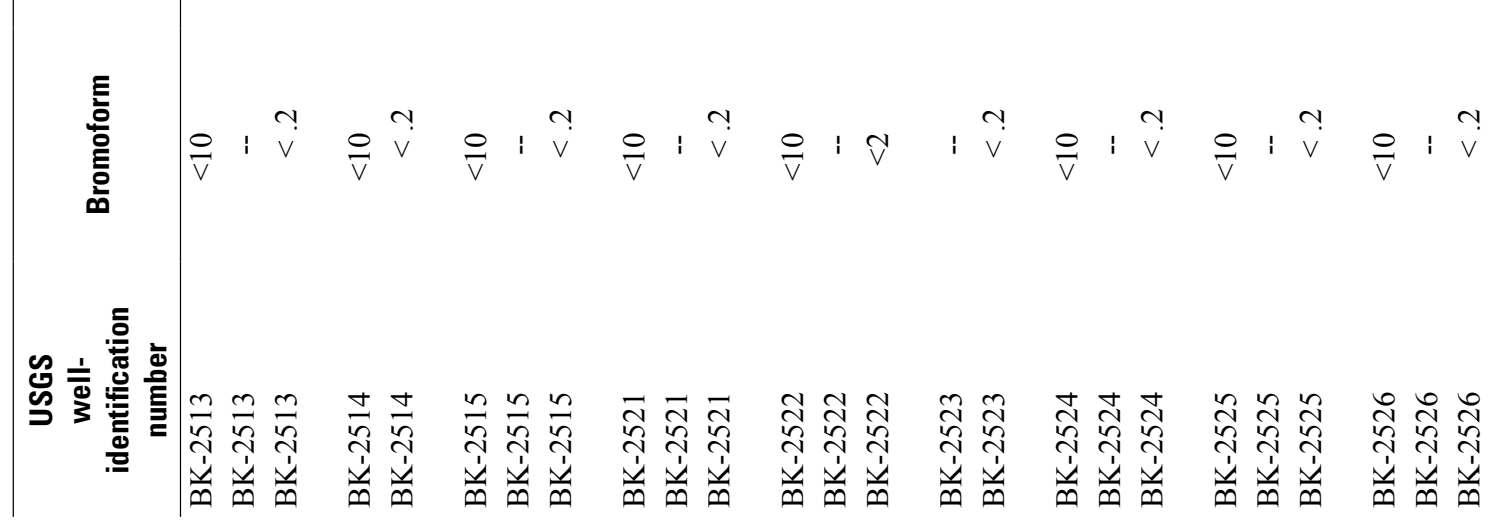




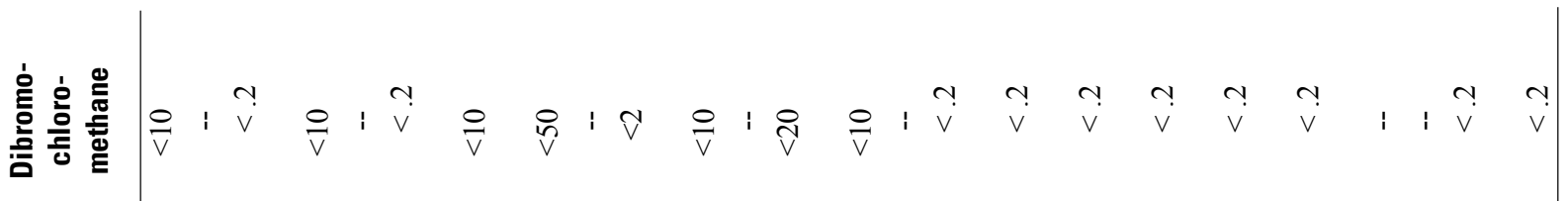

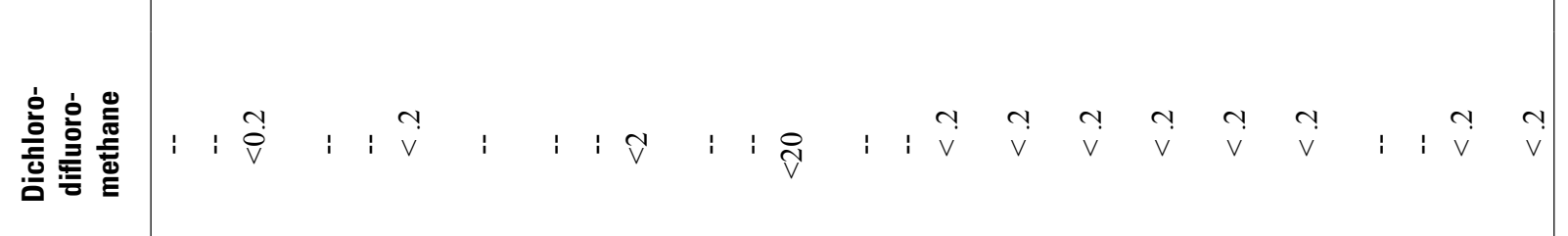

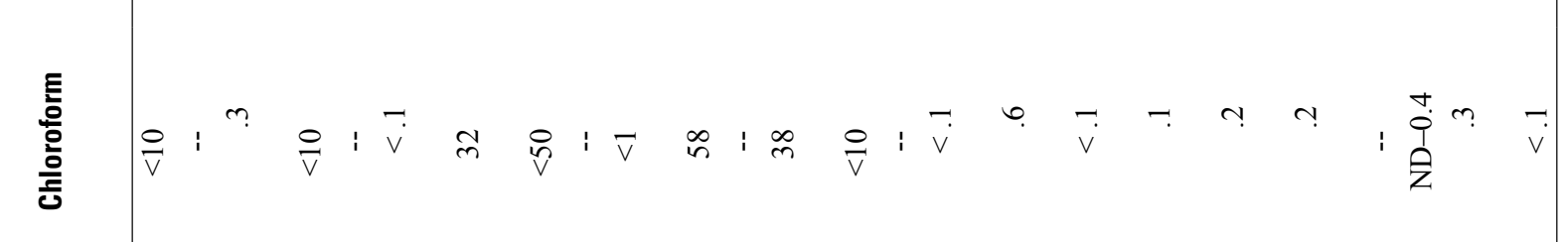

$$
\begin{aligned}
& \text { 㝘 }
\end{aligned}
$$

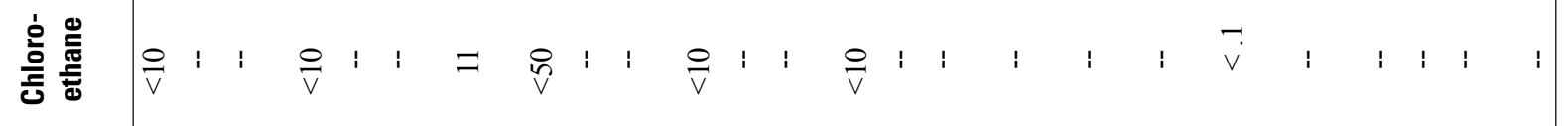

$$
\begin{aligned}
& \text { 嵩 }
\end{aligned}
$$

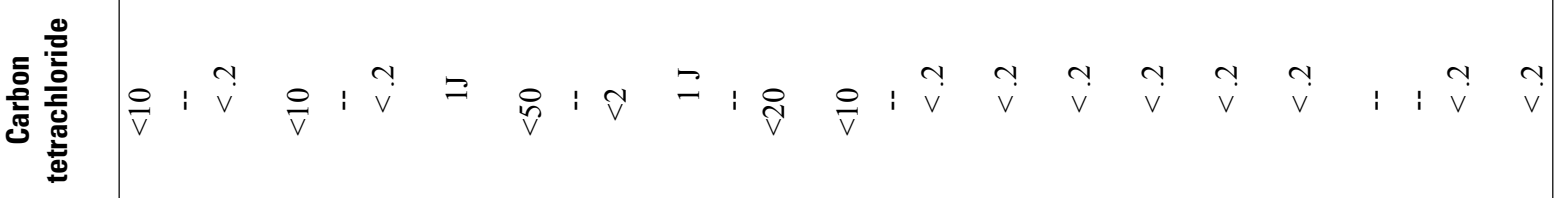

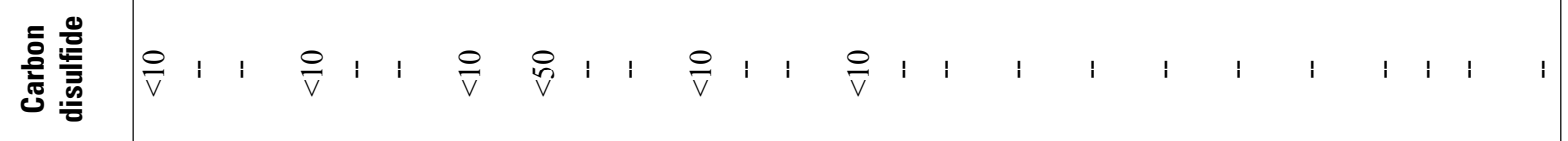

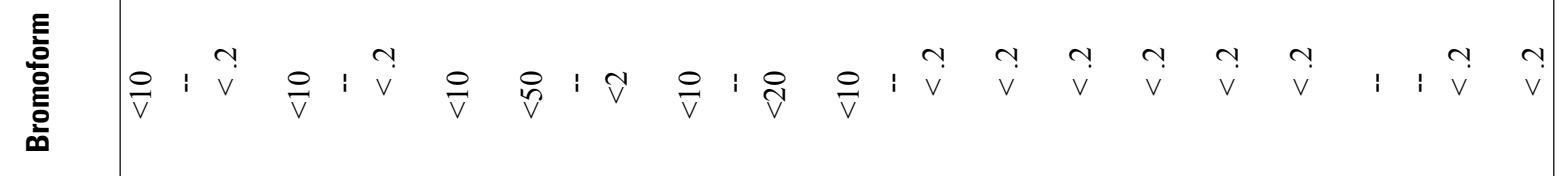

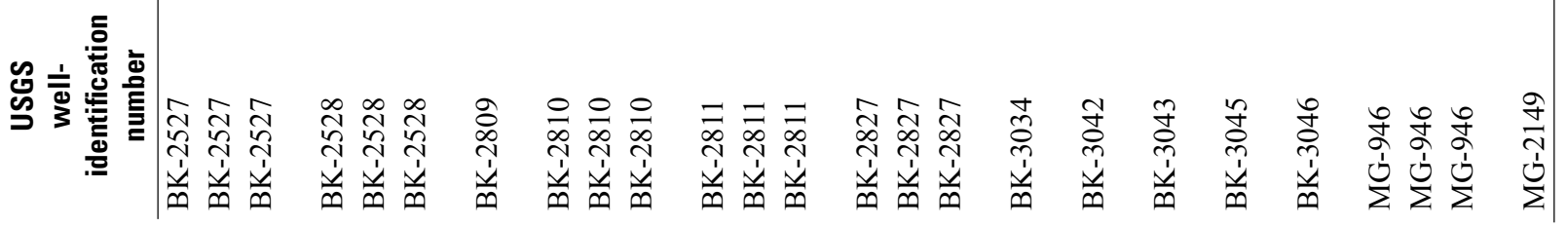




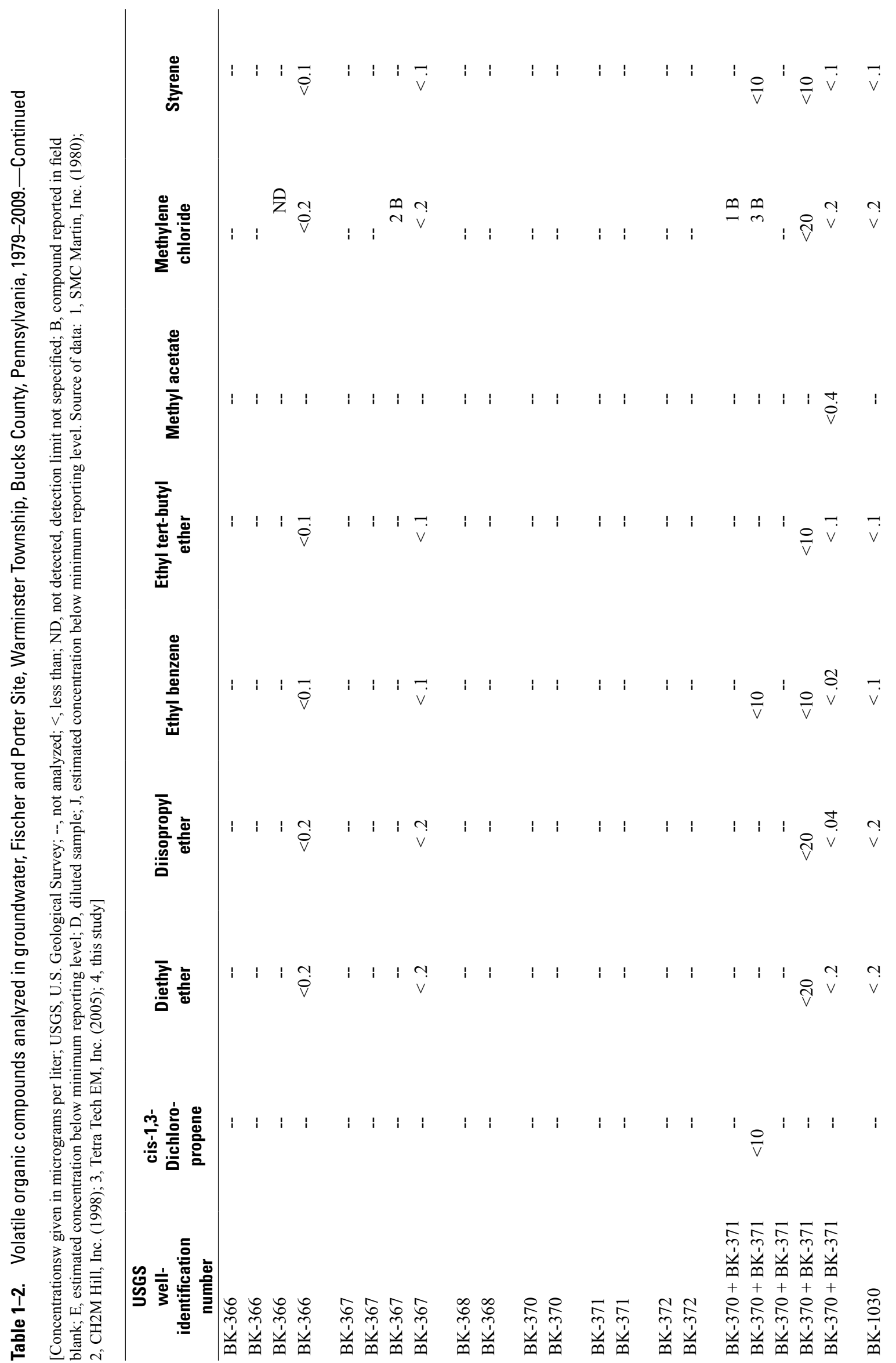



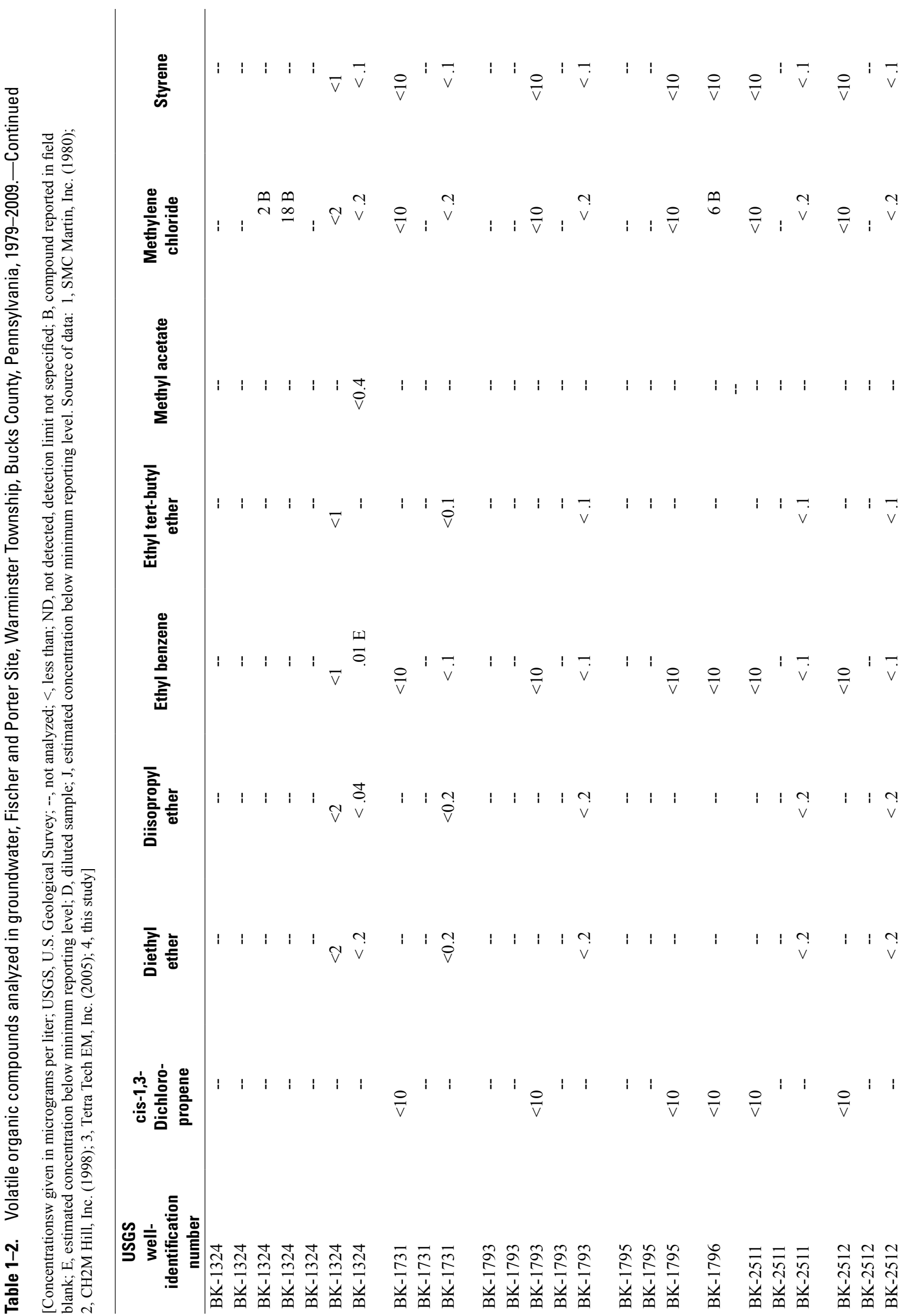


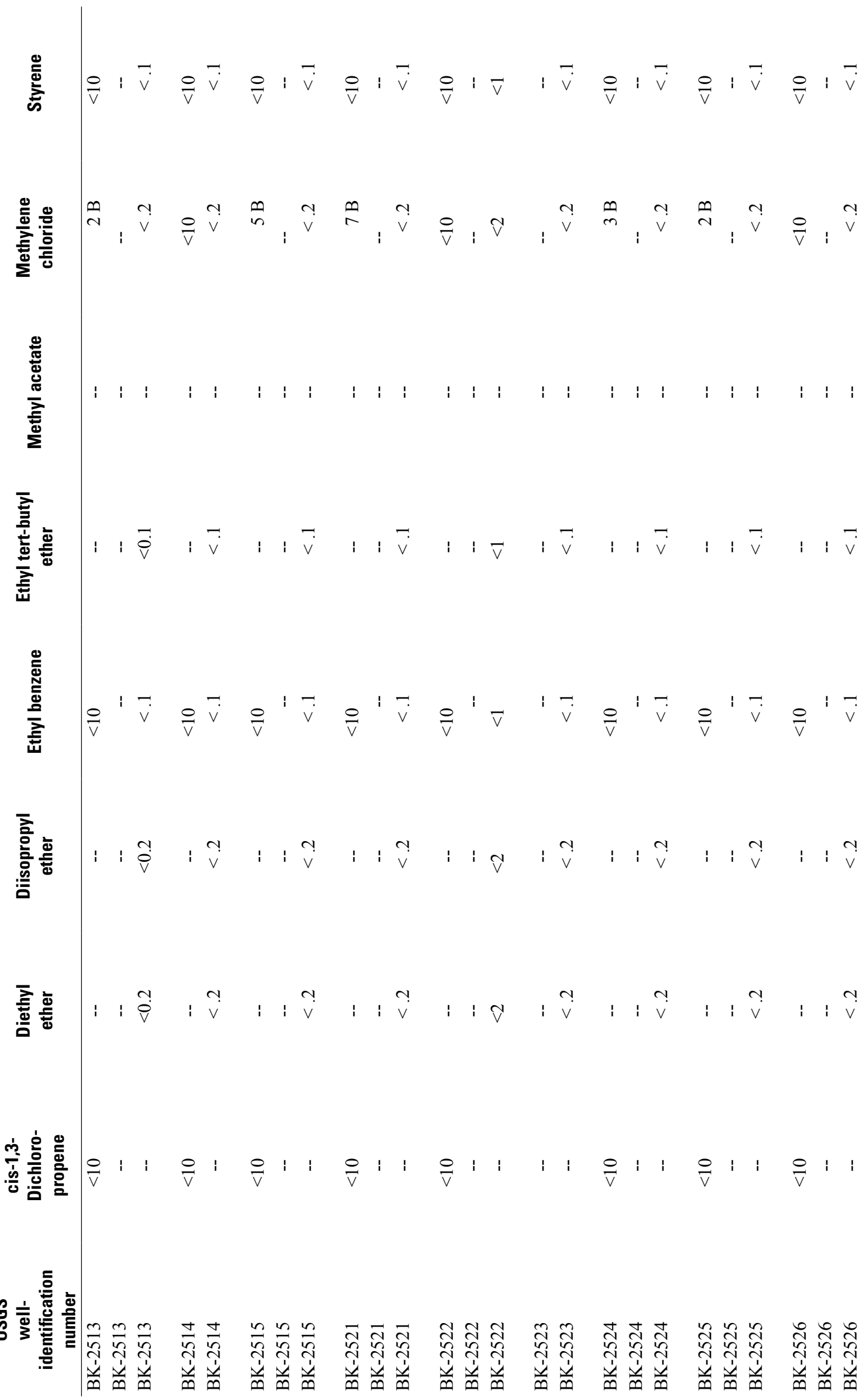




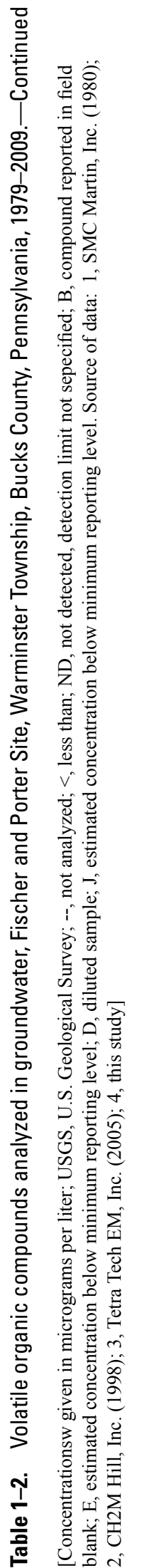

$$
\begin{aligned}
& \text { ڤ } \\
& \text { 至 }
\end{aligned}
$$

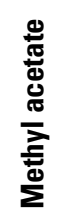

$$
\begin{aligned}
& \text { 咅 }
\end{aligned}
$$

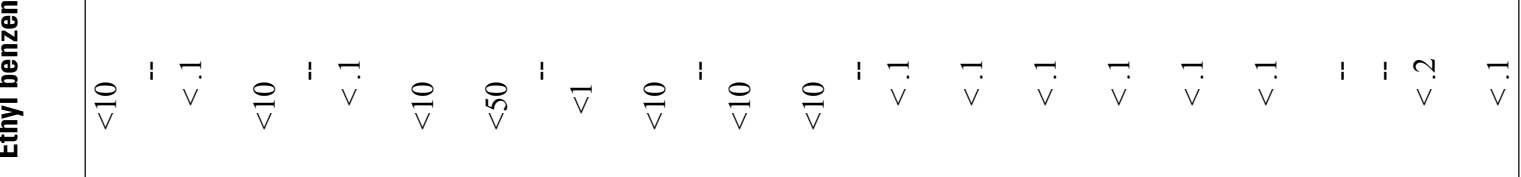

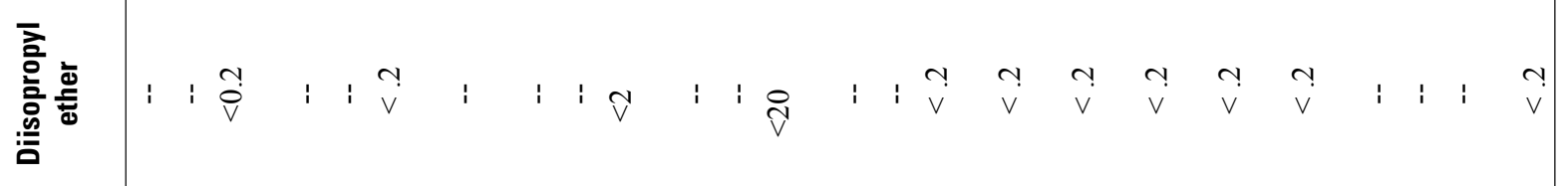

$$
\begin{aligned}
& \text { 苞 }
\end{aligned}
$$

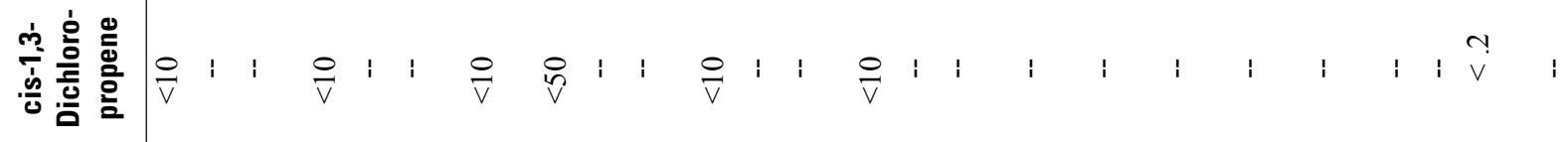

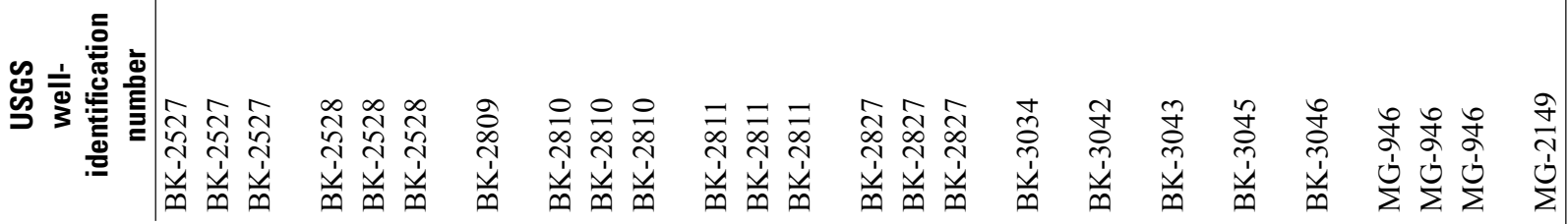




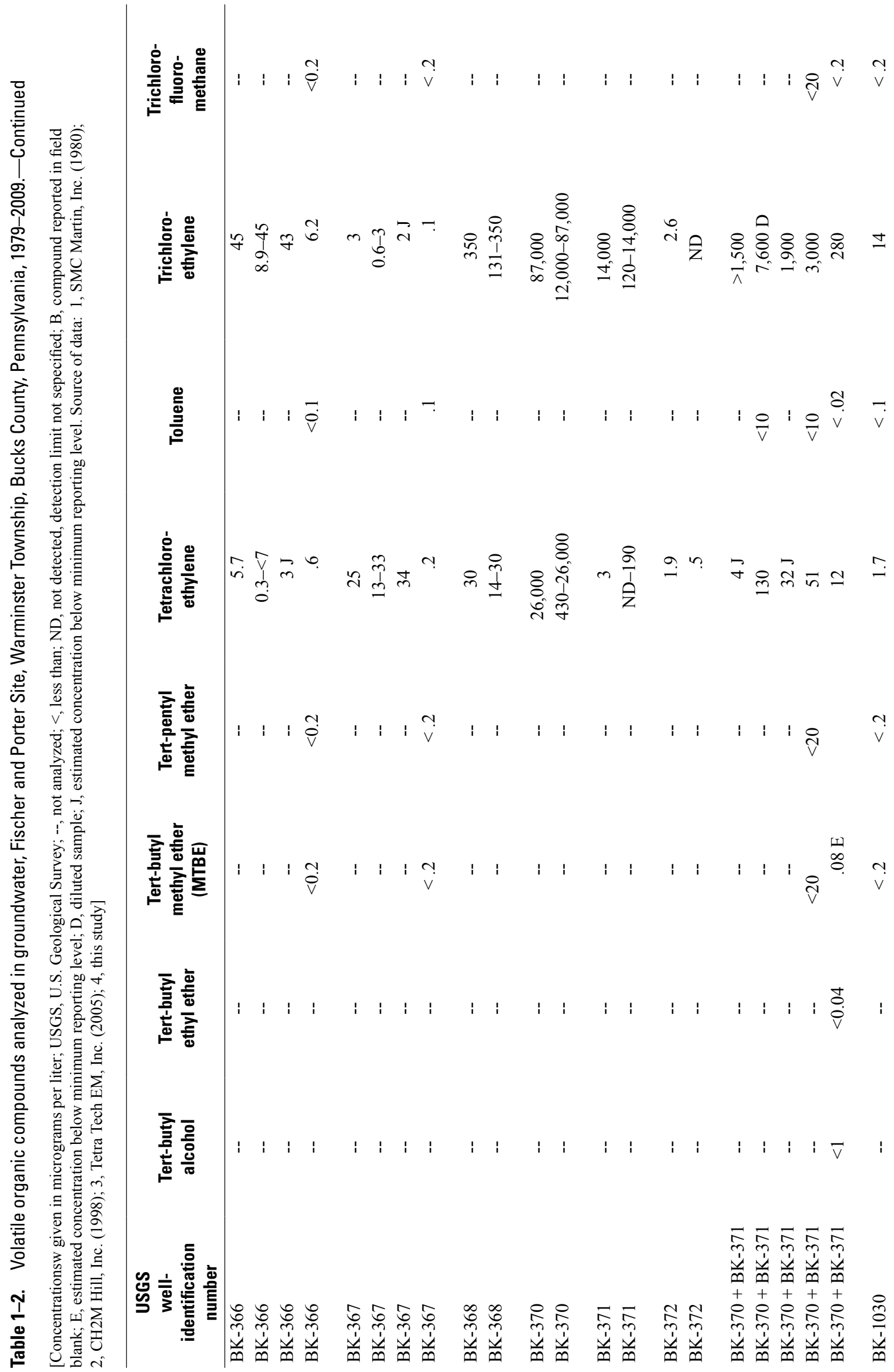



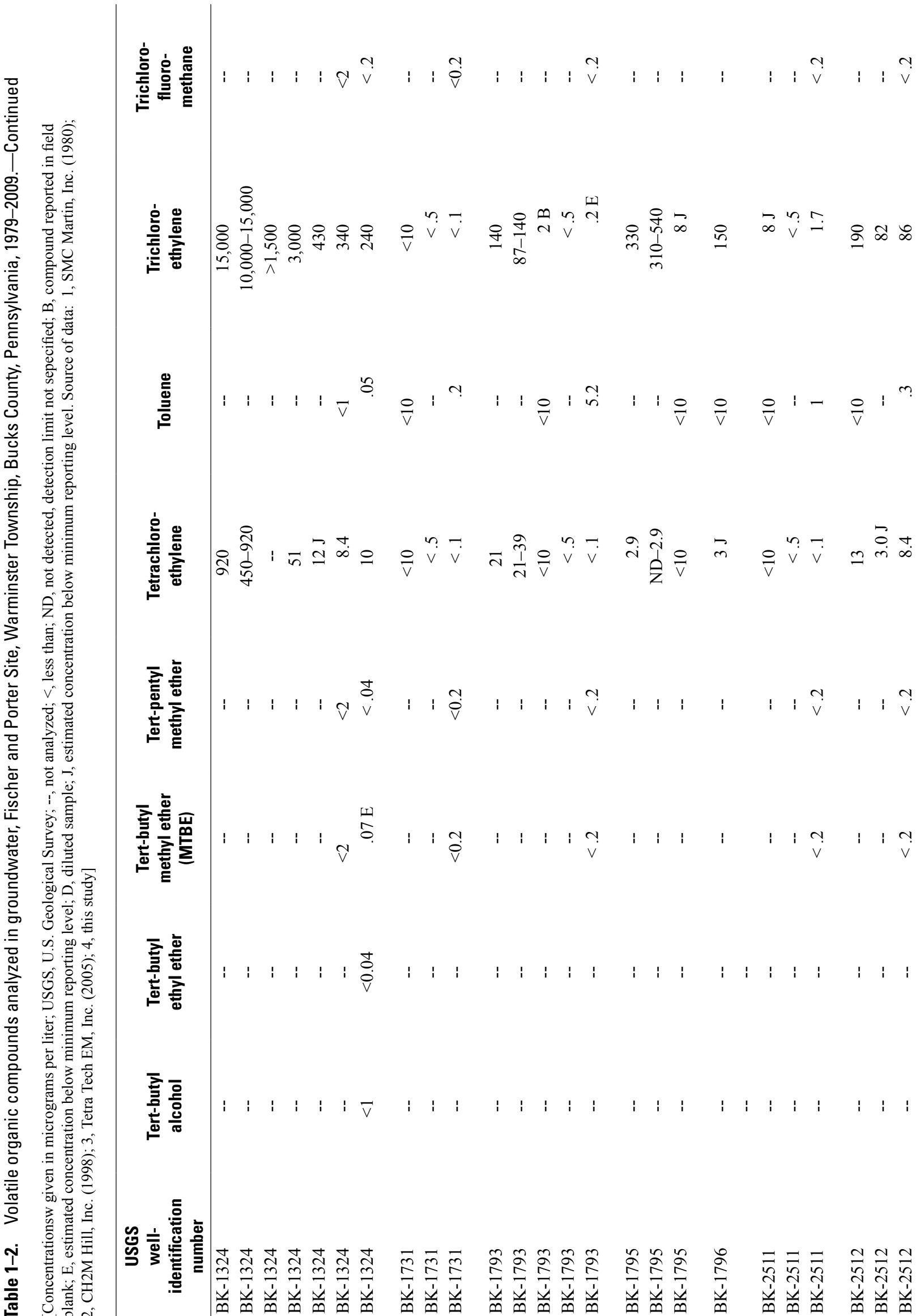

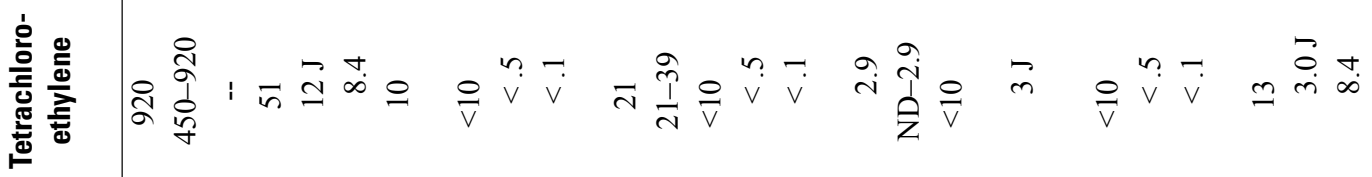
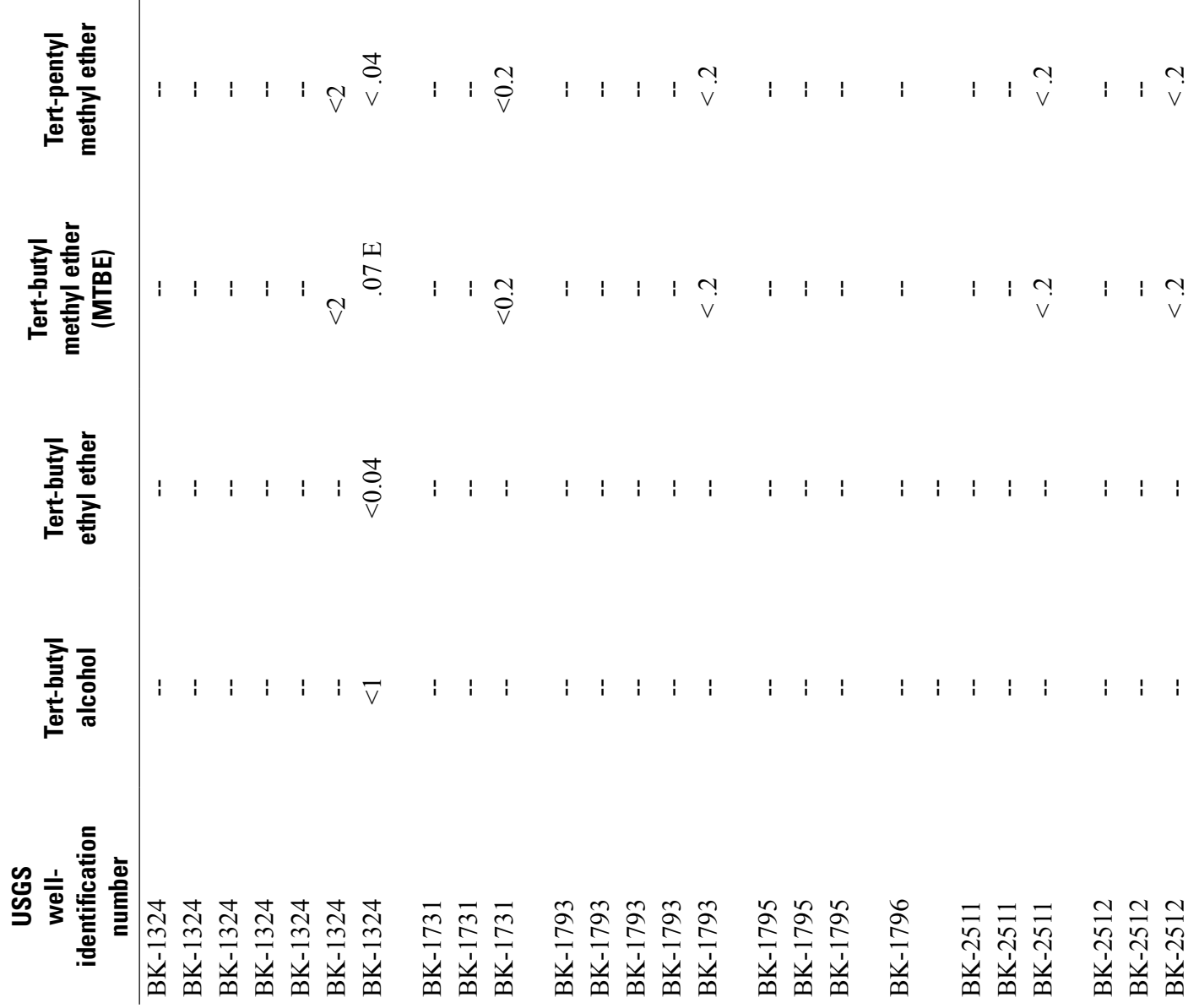

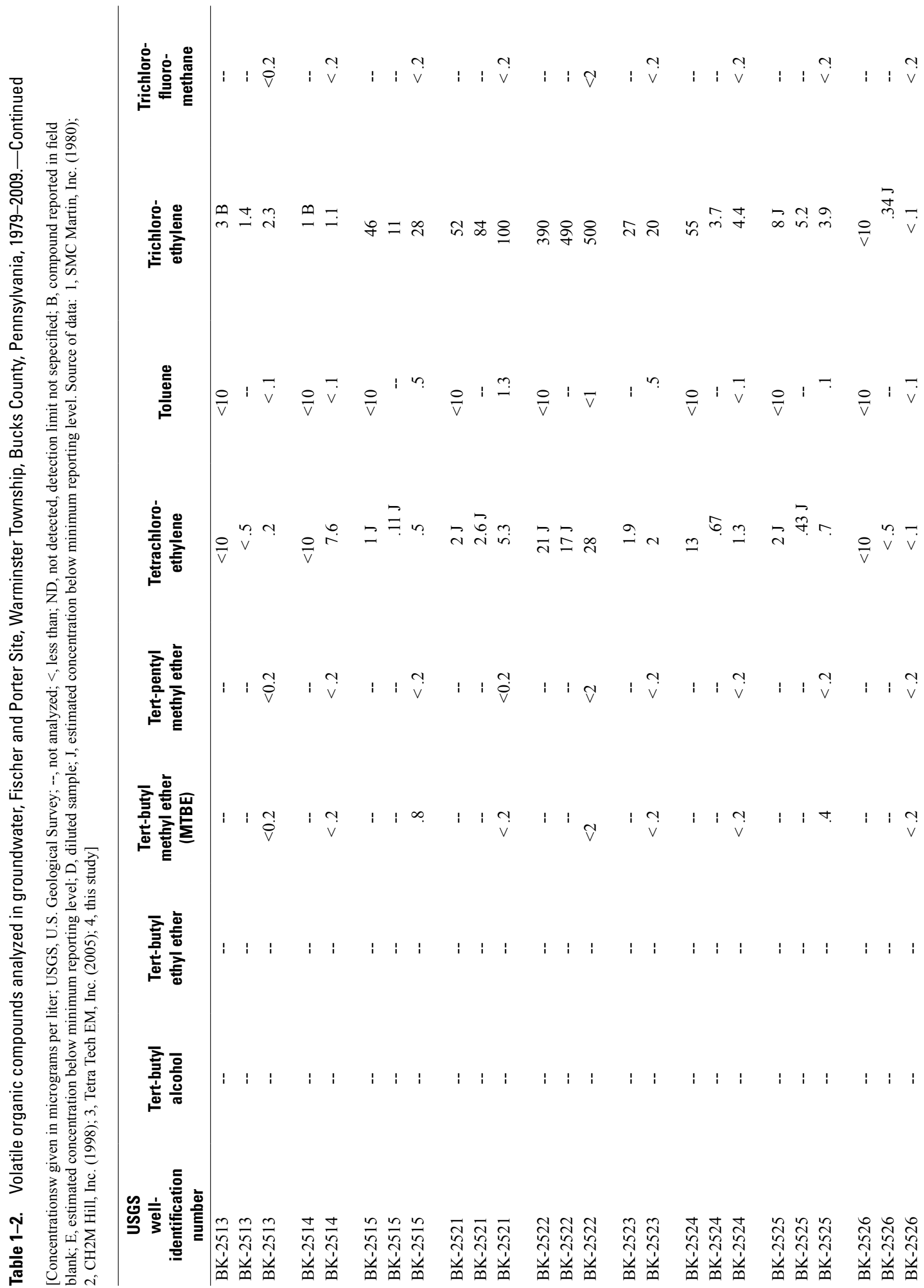

旁
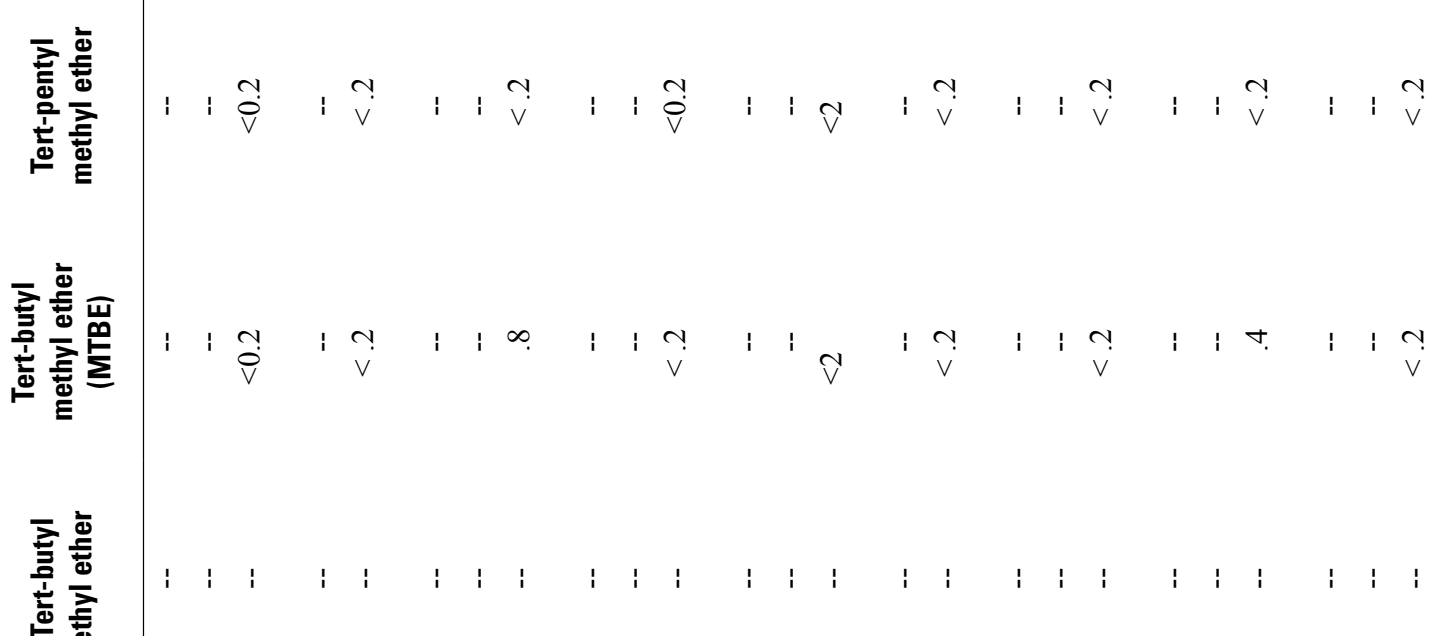

产

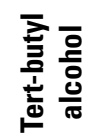

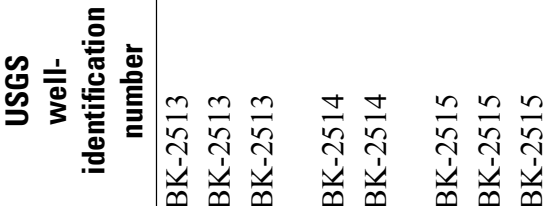

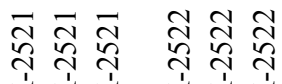

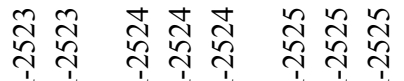

เ్రి

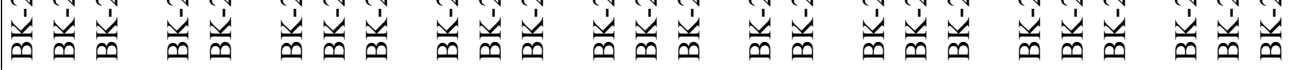




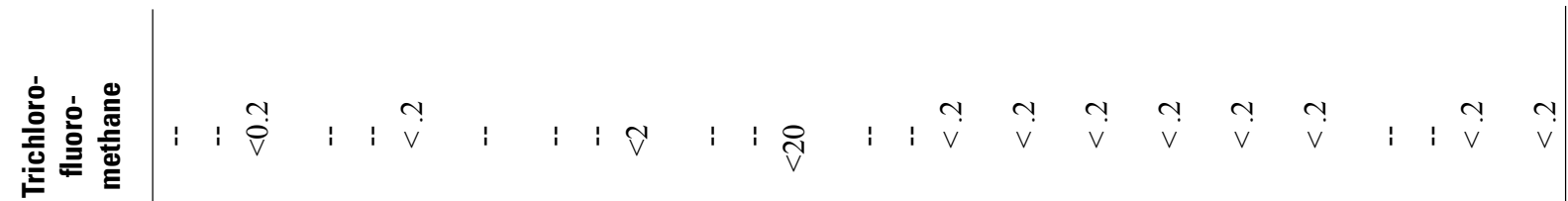

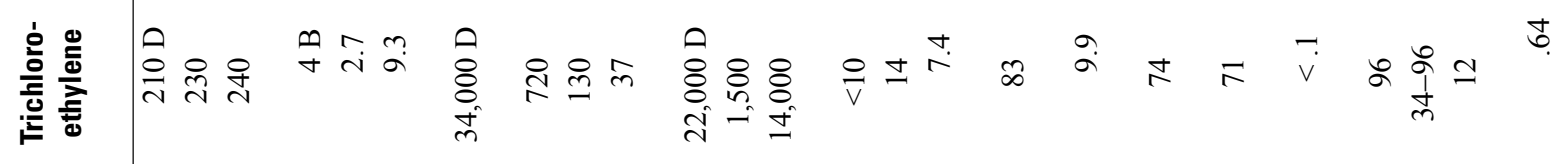

旁

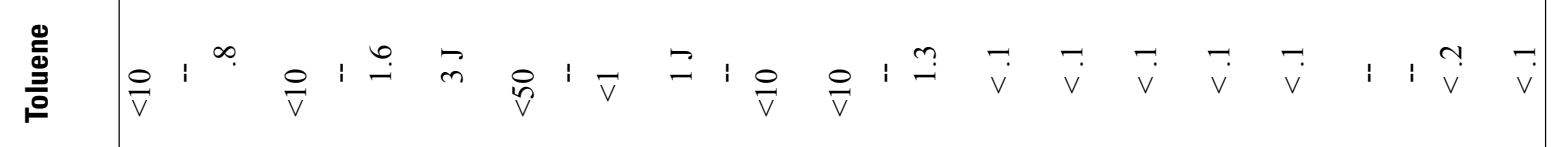

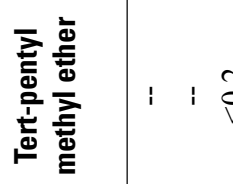

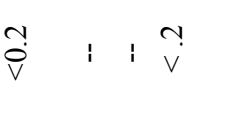

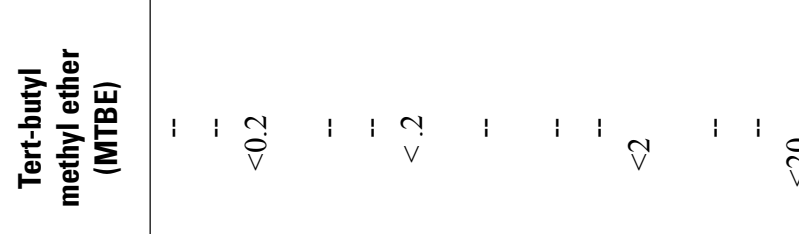

远

흥

出言离离

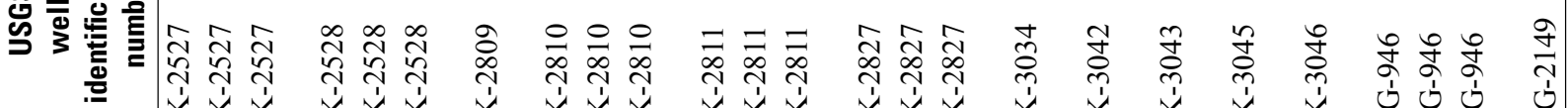

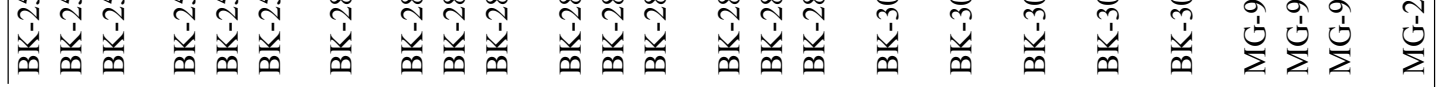



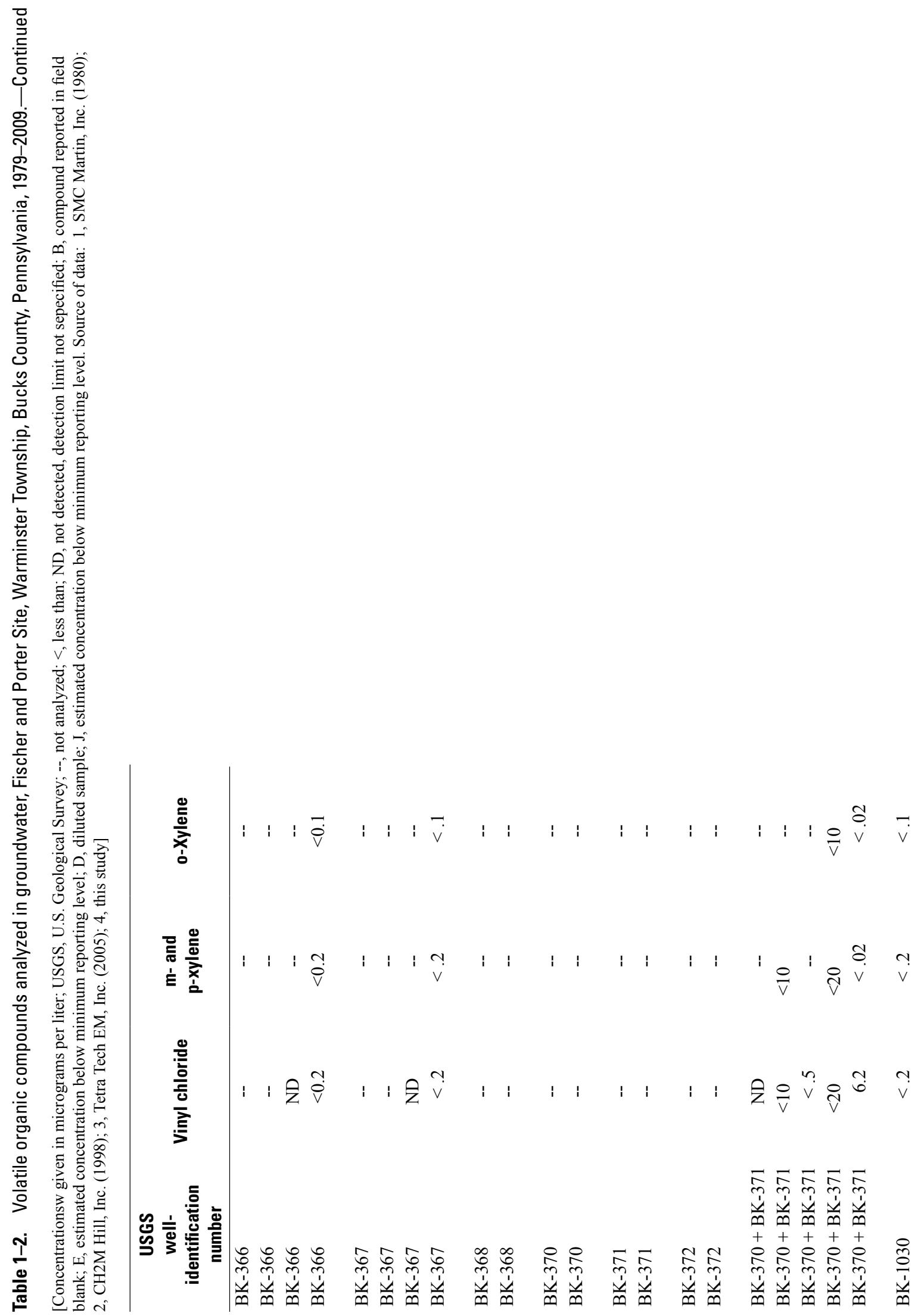


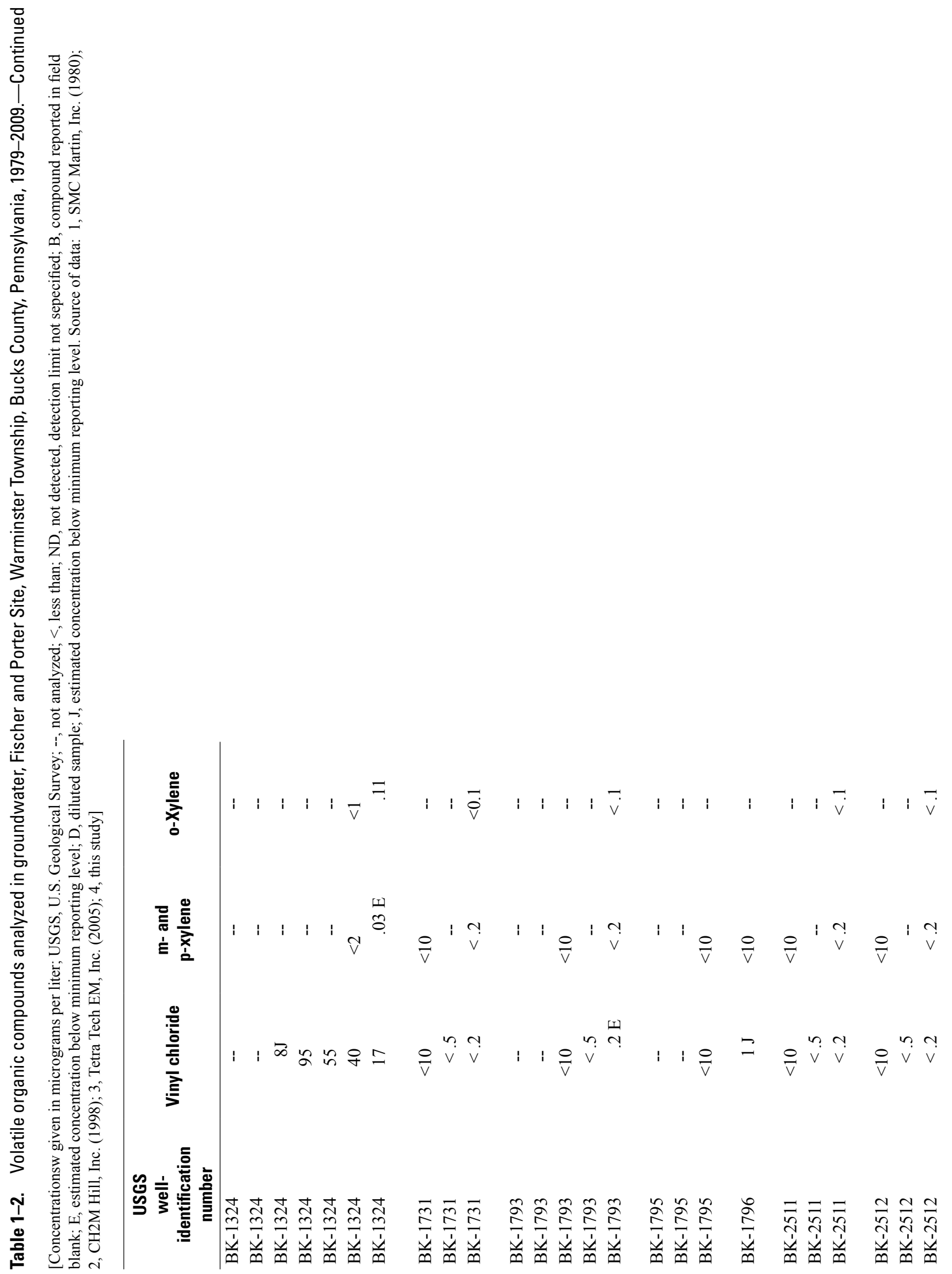



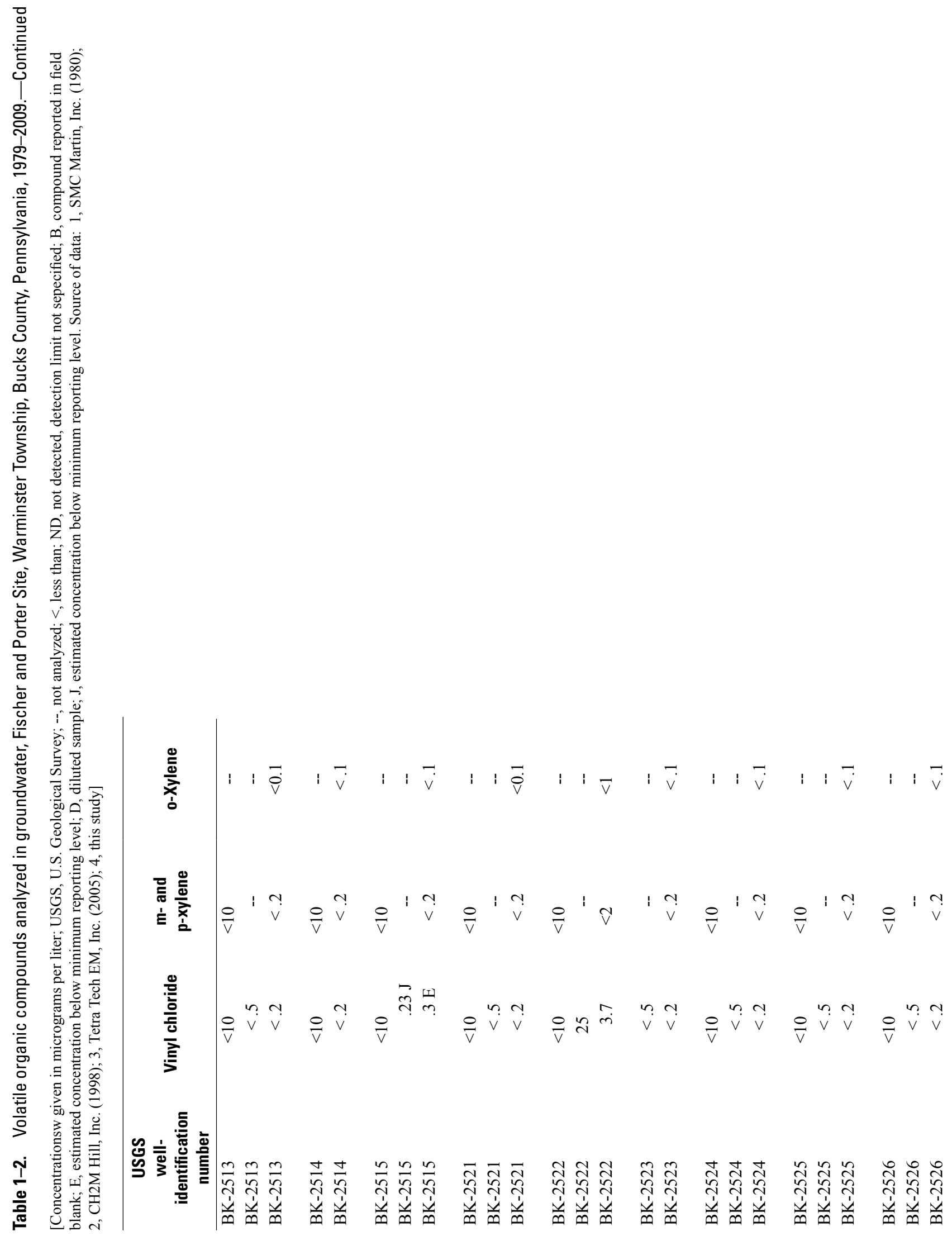


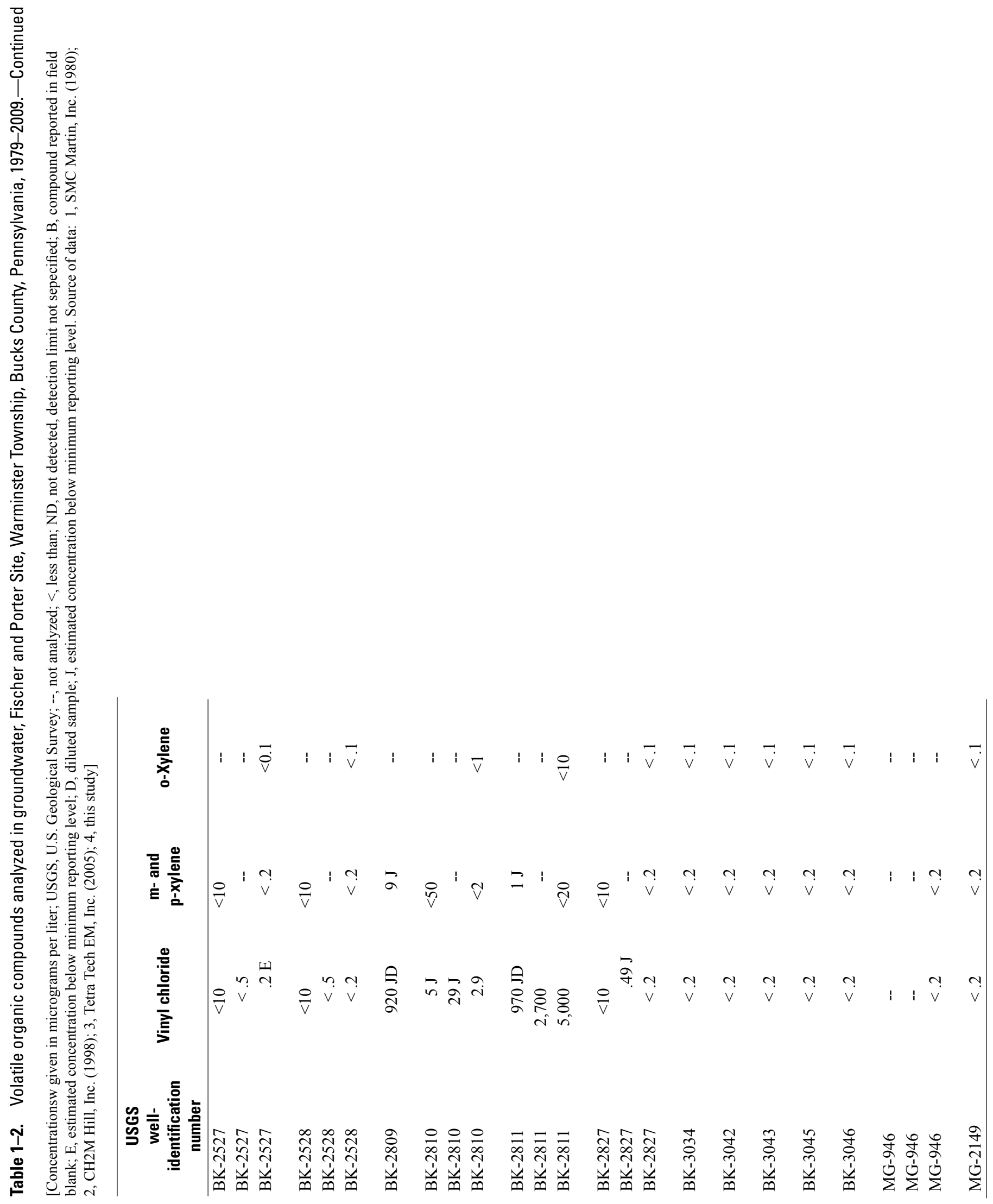




\section{Appendix 2. Borehole Geophysical Logs}
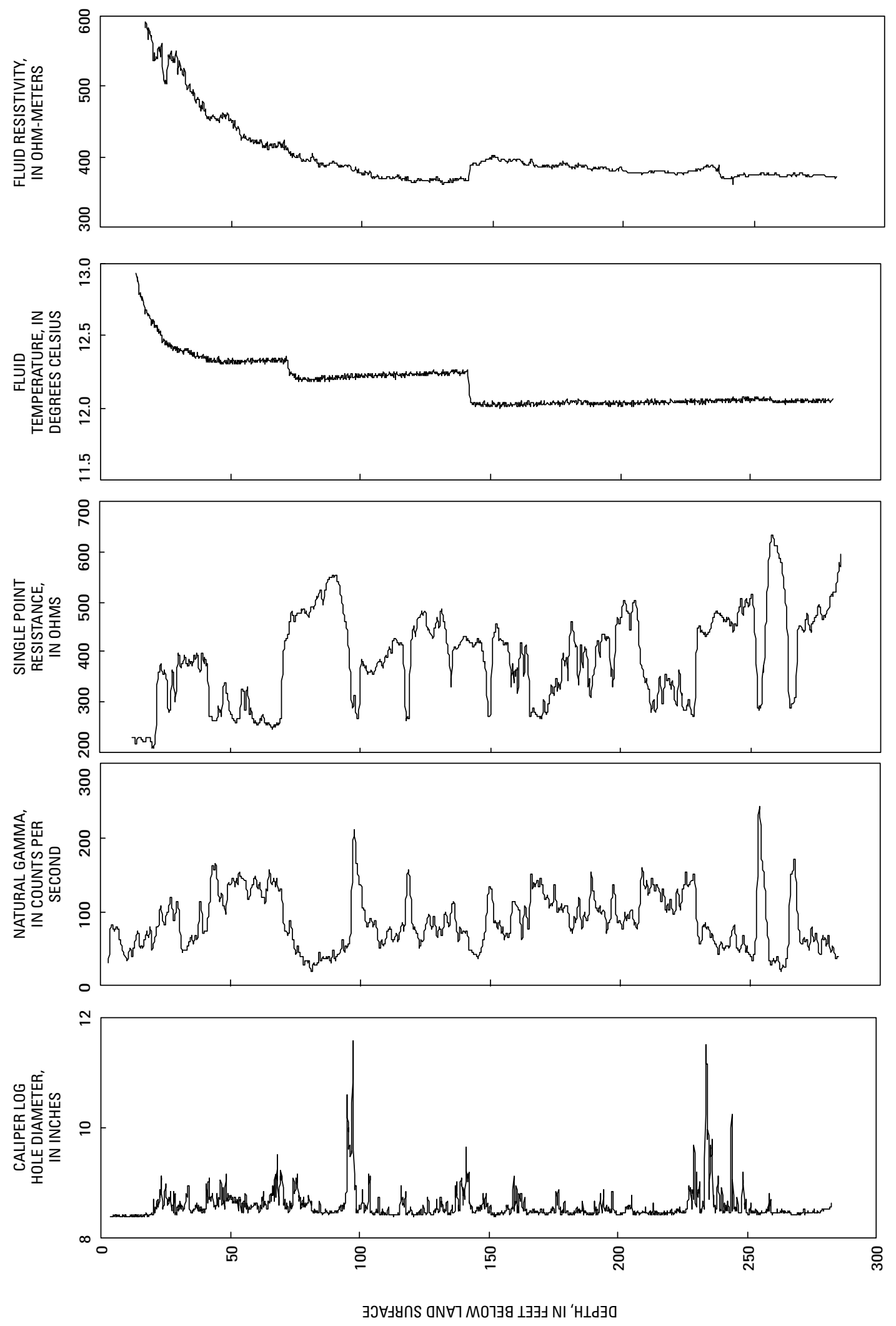

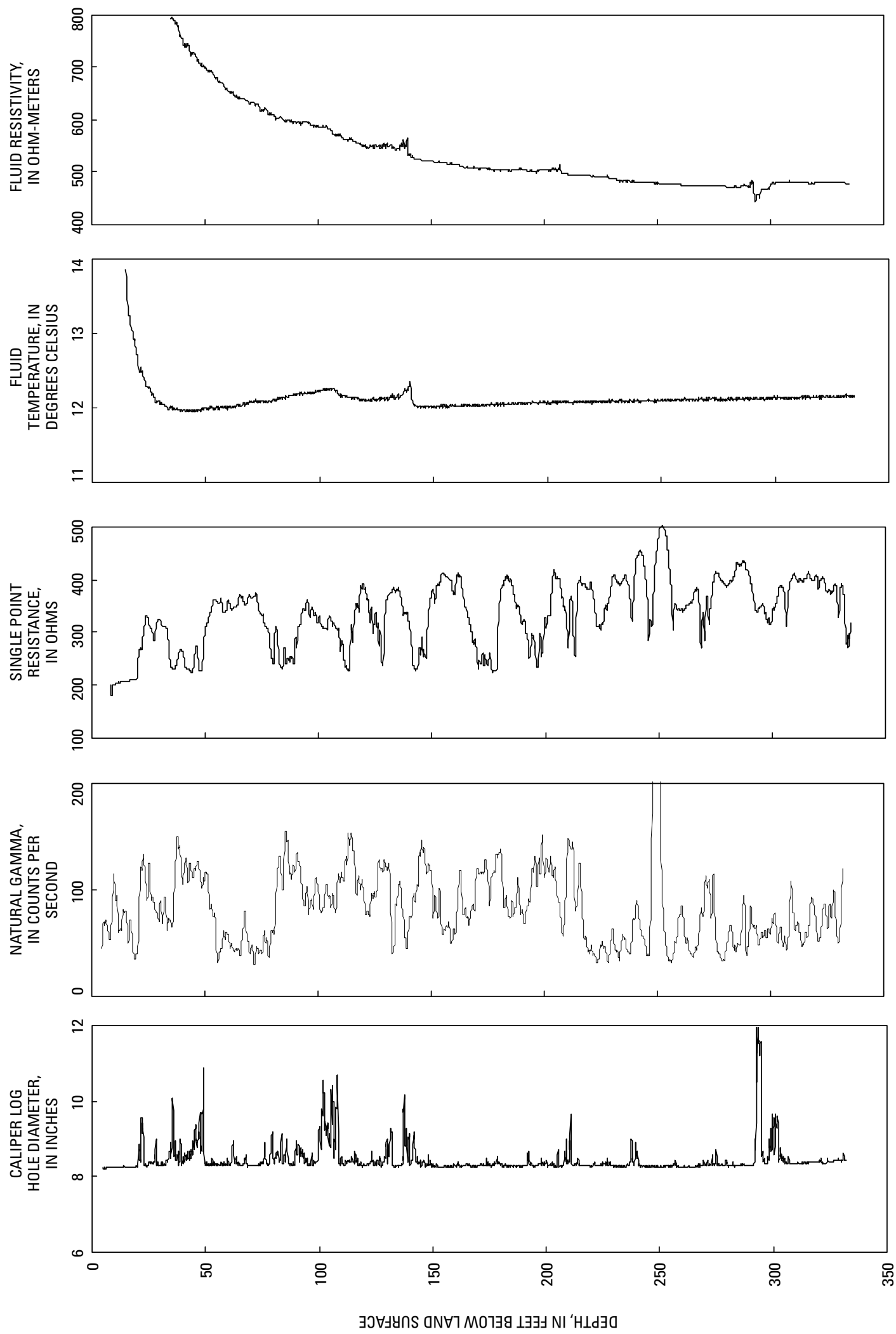

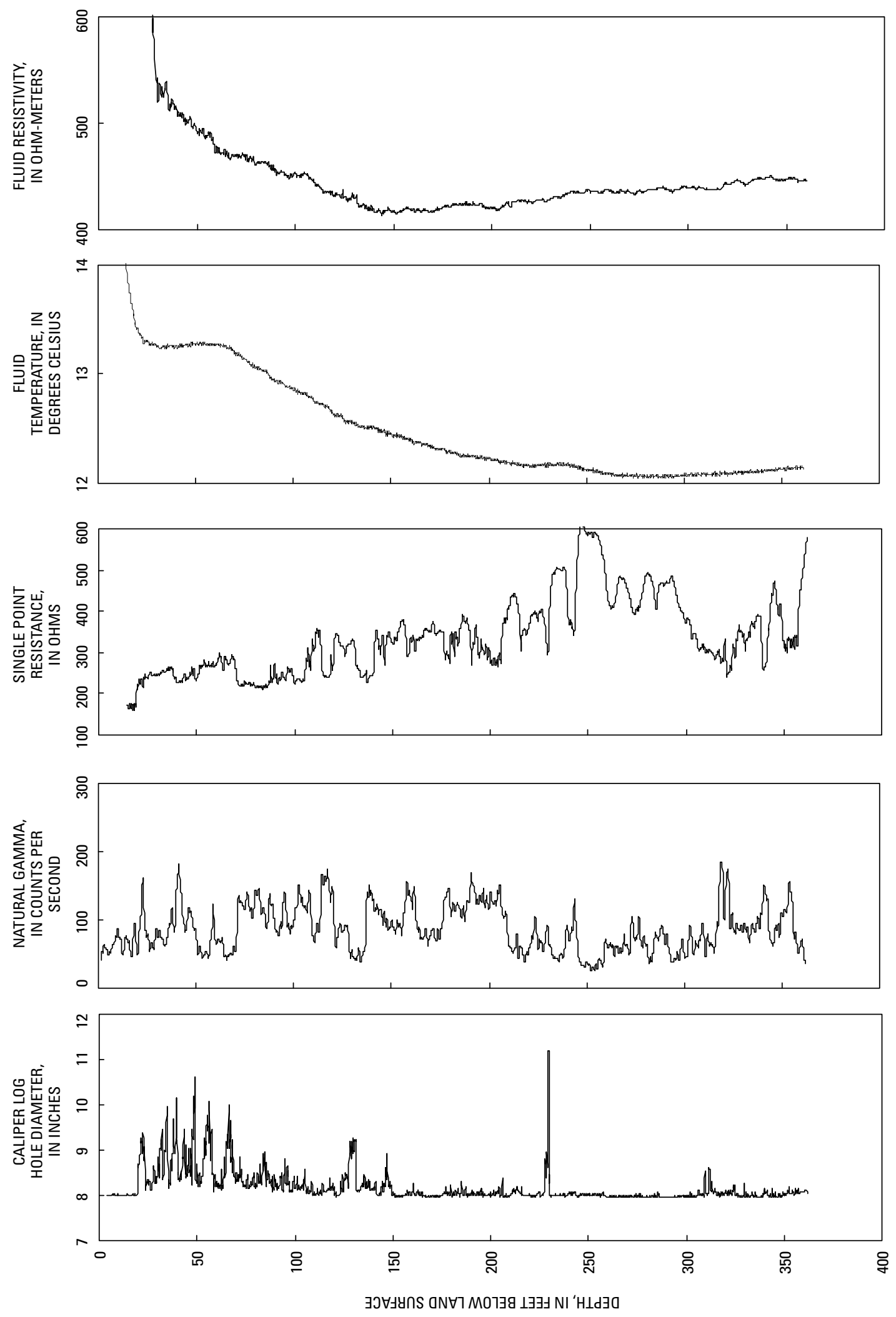

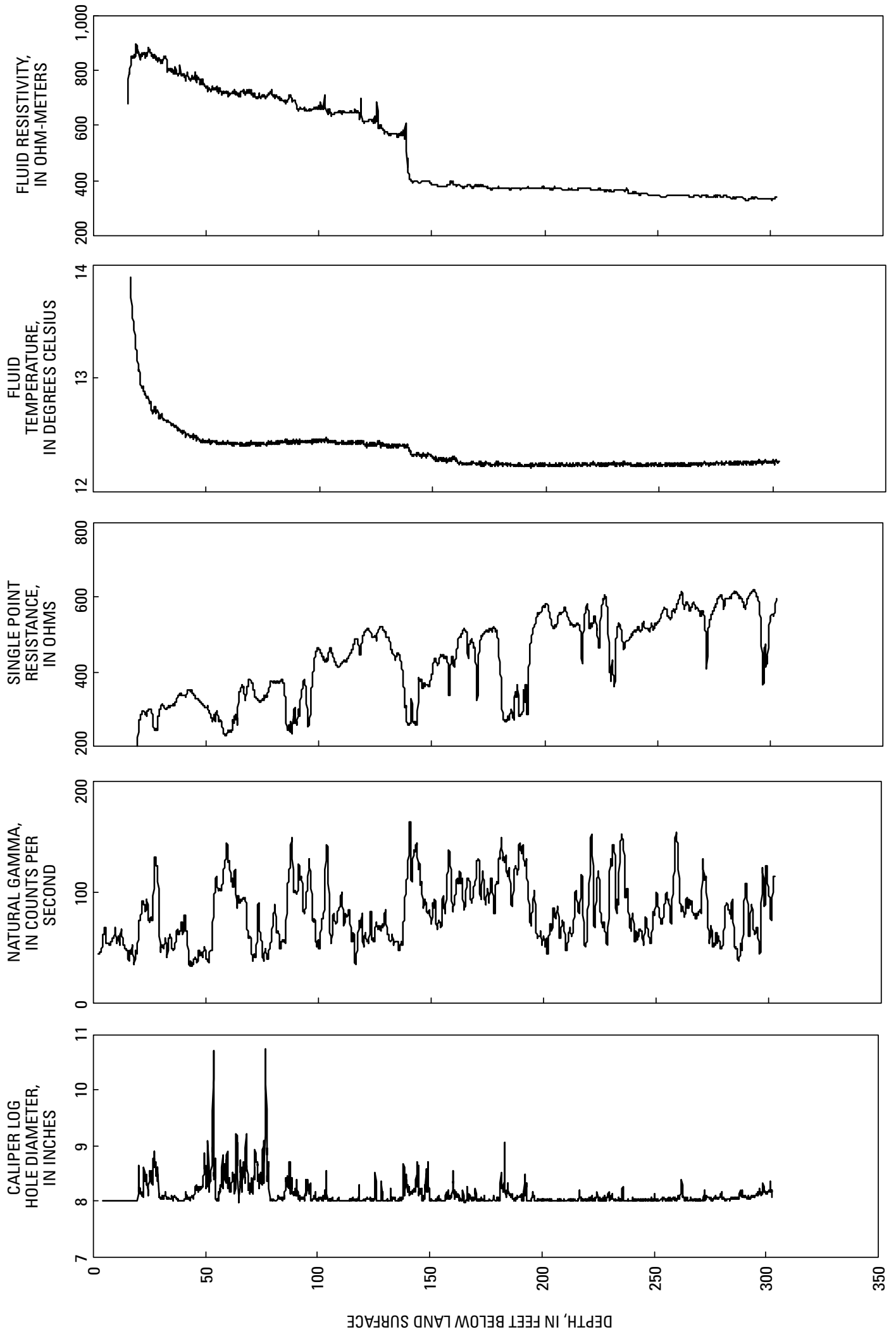

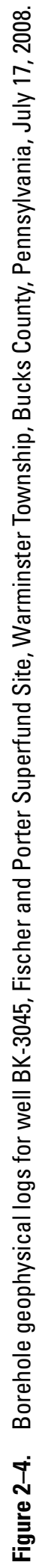



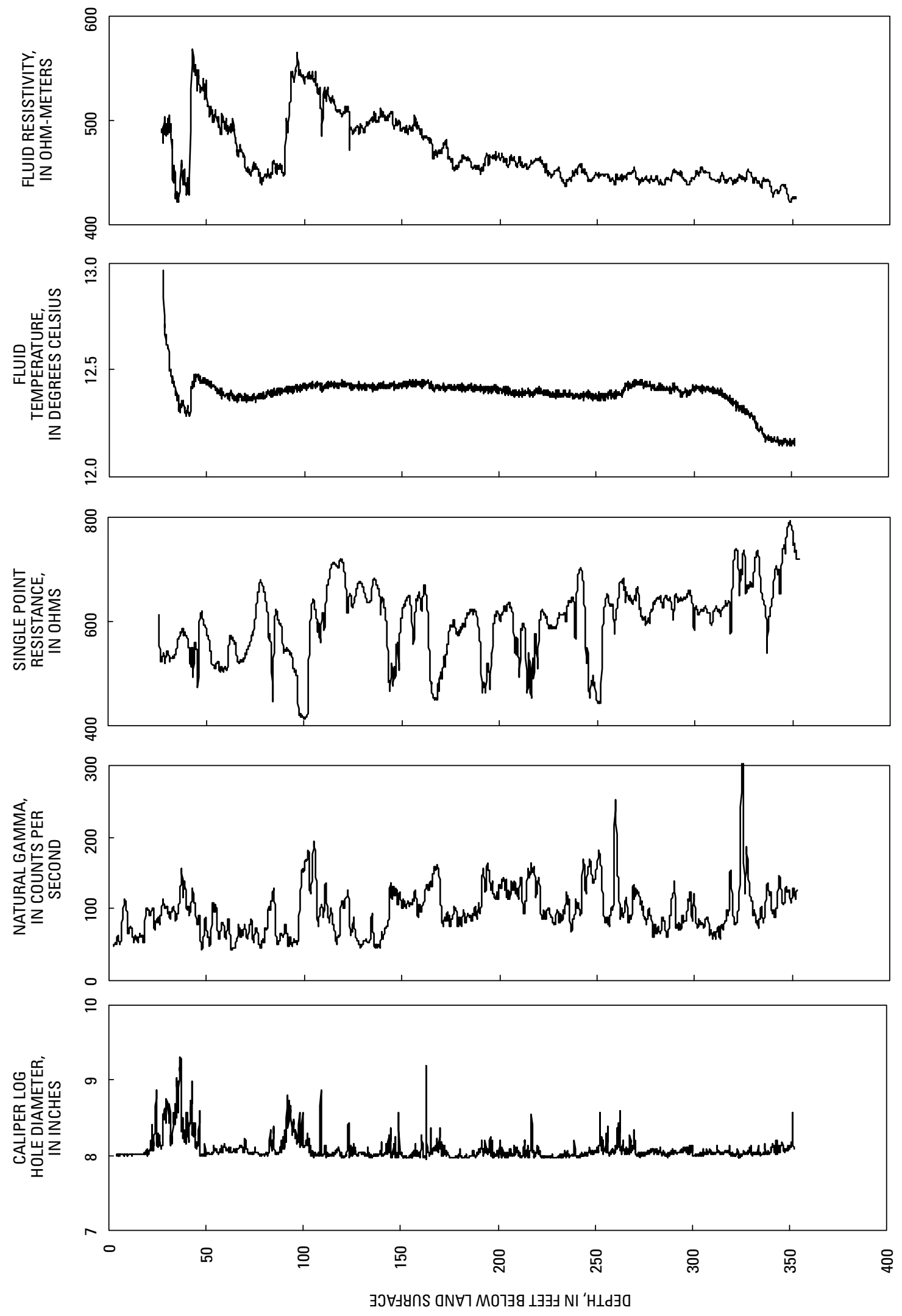


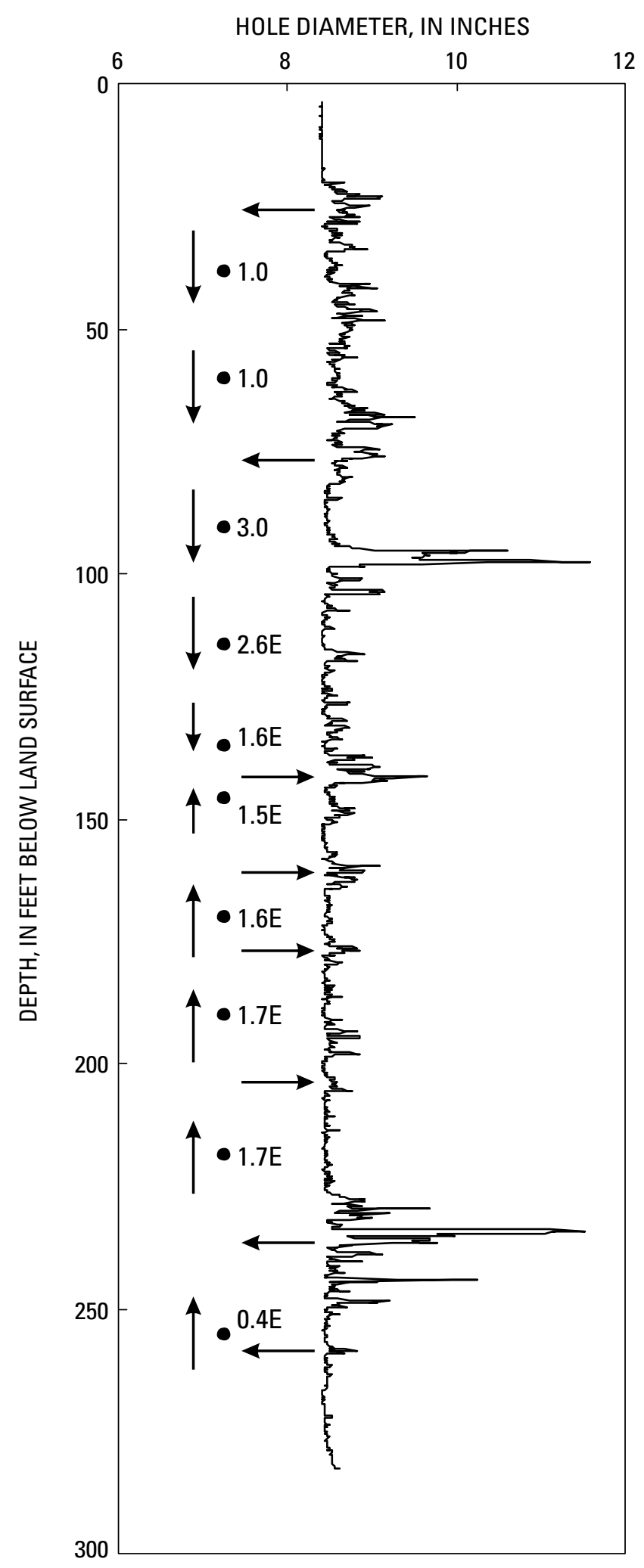

\section{EXPLANATION}

1.0 BOREHOLE-FLOW MEASUREMENT UNDER NONPUMPING CONDITIONS - Circle at depth of flow measurement. Number is measured flow in gallons per minute.

2.6E ESTIMATED BOREHOLE-FLOW MEASUREMENT UNDER NONPUMPING CONDITIONS - Circle at depth of flow measurement. Number is estimated flow in gallons per minute.

$\uparrow \mid$ DIRECTION OF VERTICAL BOREHOLE FLOW -

Upward arrow indicates upward flow; downward arrow indicates downward flow.

FLOW INTO BOREHOLE - Arrow pointing away from caliper log indicates flow into borehole.

FLOW OUT OF BOREHOLE - Arrow pointing towards caliper log indicates flow out of borehole.

Figure 2-6. Heatpulse-flowmeter measurements for well BK-3042, Fischer and Porter Superfund Site, Warminster Township, Bucks County, Pennsylvania, July 17, 2008. 
HOLE DIAMETER, IN INCHES

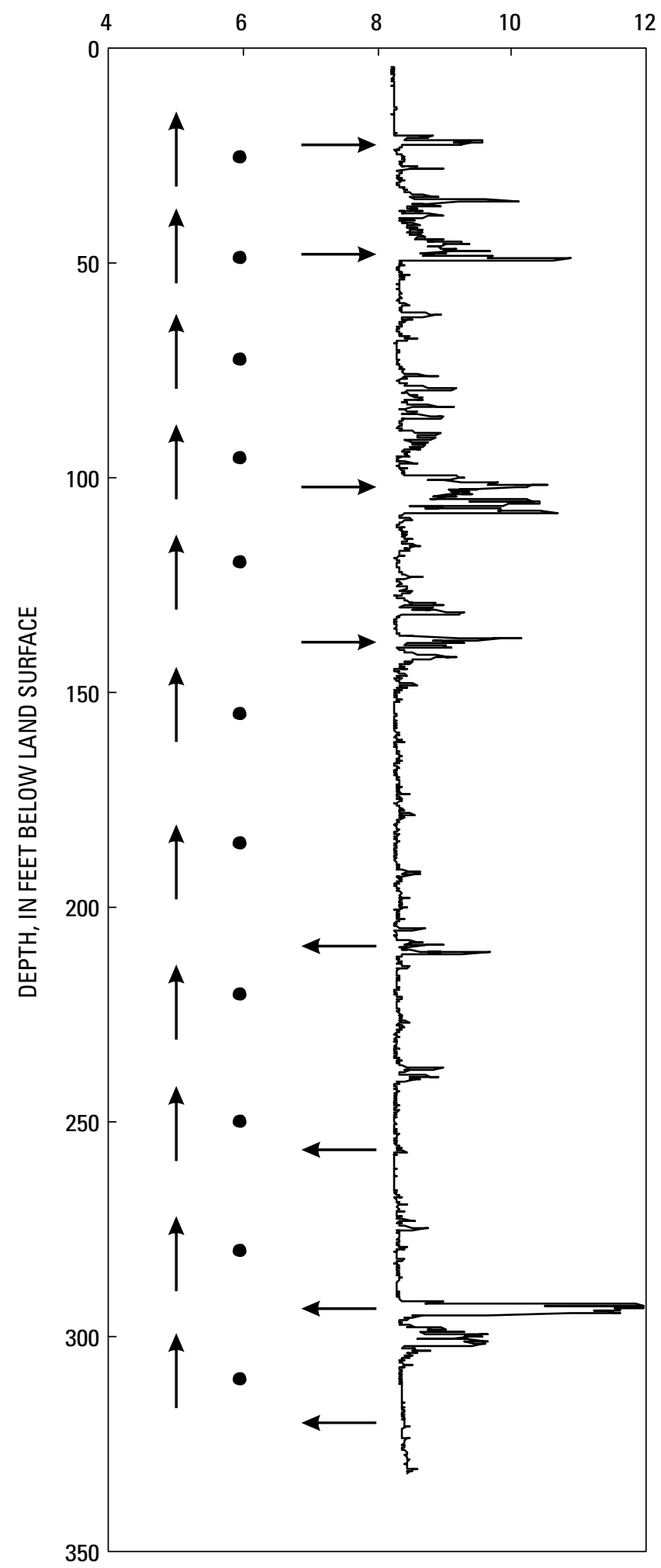

\section{EXPLANATION}

BOREHOLE-FLOW MEASUREMENT UNDER

- NONPUMPING CONDITIONS - Circle at depth of flow measurement. Rate of flow greater than upper limit of instrument.

DIRECTION OF VERTICAL BOREHOLE FLOW Upward arrow indicates upward flow.

$\longleftarrow$ FLOW INTO BOREHOLE - Arrow pointing away from caliper log indicates flow into borehole. Flow inferred from fluid-temperature and fluid-resistivity geophysical logs.

FLOW OUT OF BOREHOLE - Arrow pointing towards caliper log indicates flow out of borehole. Flow inferred from fluid-temperature and fluidresistivity geophysical logs.

Figure 2-7. Heatpulse-flowmeter measurements for well BK-3043, Fischer and Porter Superfund Site, Warminster Township, Bucks County, Pennsylvania, July 15, 2008. 


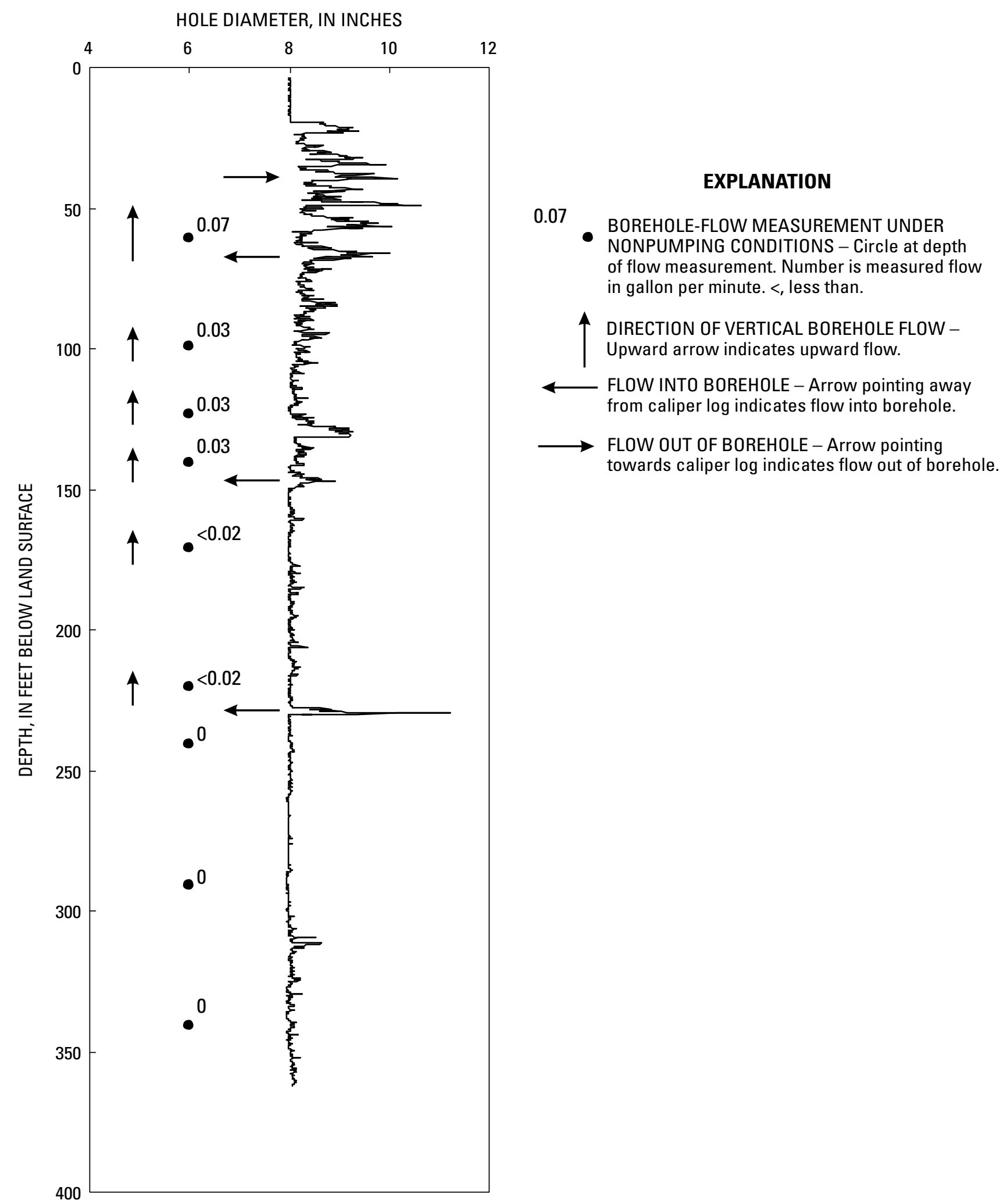

Figure 2-8. Heatpulse-flowmeter measurements for well BK-3044, Fischer and Porter Superfund Site, Warminster Township, Bucks County, Pennsylvania, July 16, 2008. 


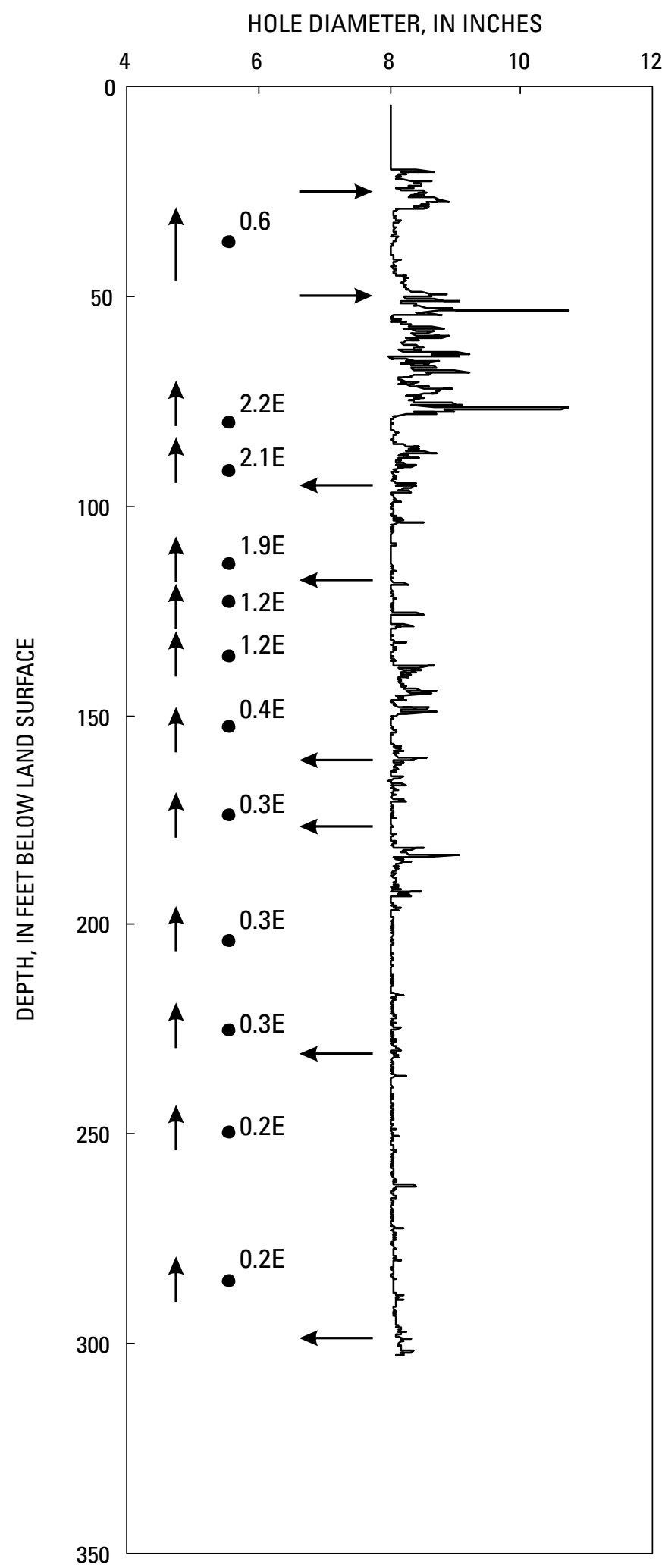

\section{EXPLANATION}

0.6 BOREHOLE-FLOW MEASUREMENT UNDER NONPUMPING CONDITIONS - Circle at depth of flow measurement. Number is measured flow in gallon per minute.

2.1E ESTIMATED BOREHOLE-FLOW MEASUREMENT UNDER NONPUMPING CONDITIONS - Circle at depth of flow measurement. Number is estimated flow in gallons per minute.

$\uparrow$ DIRECTION OF VERTICAL BOREHOLE FLOW Upward arrow indicates upward flow.

FLOW INTO BOREHOLE - Arrow pointing away from caliper log indicates flow into borehole.

FLOW OUT OF BOREHOLE - Arrow pointing towards caliper log indicates flow out of borehole.

Figure 2-9. Heatpulse-flowmeter measurements for well BK-3045, Fischer and Porter Superfund Site, Warminster Township, Bucks County, Pennsylvania, July 17, 2008. 


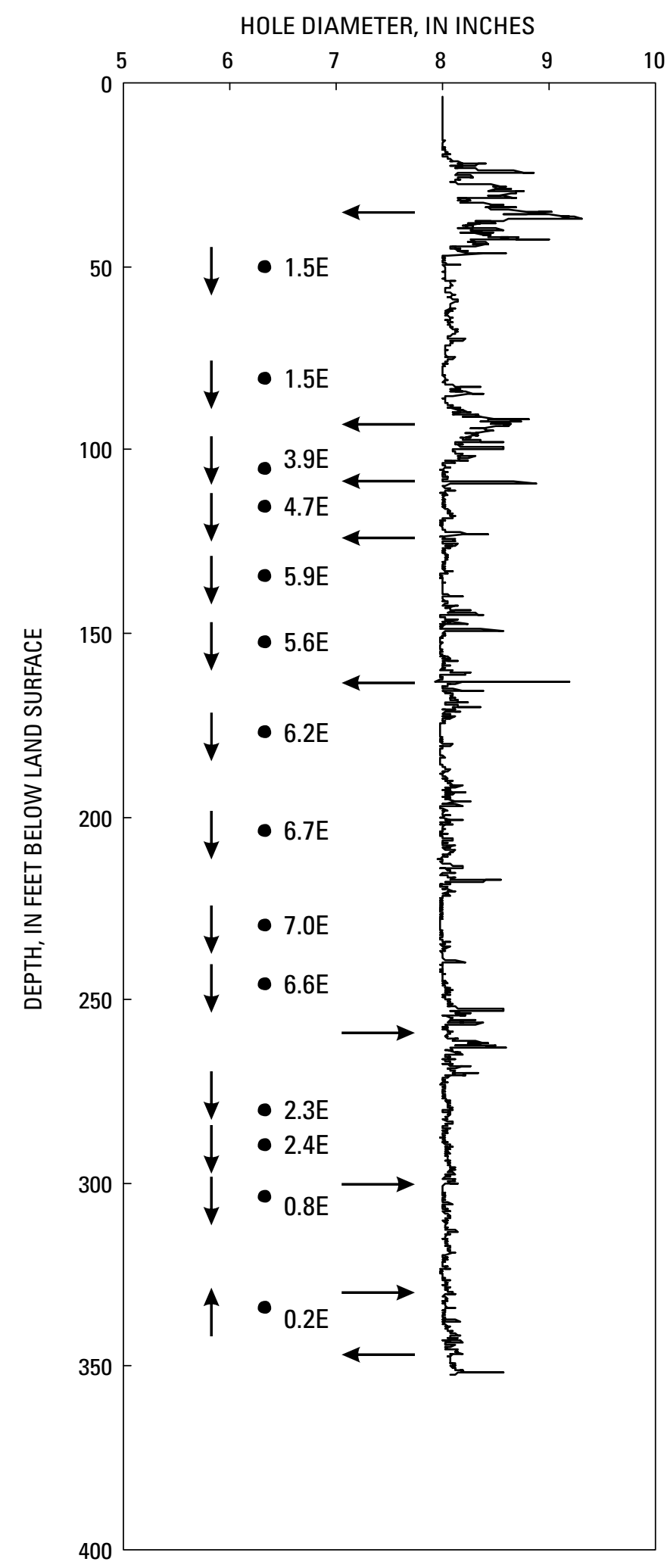

\section{EXPLANATION}

2.6E ESTIMATED BOREHOLE-FLOW MEASUREMENT UNDER NONPUMPING CONDITIONS - Circle at depth of flow measurement. Number is estimated flow in gallons per minute.

$\uparrow \downarrow \begin{aligned} & \text { DIRECTION OF VERTICAL BOREHOLE FLOW - } \\ & \text { Upward arrow indicates upward flow; downward } \\ & \text { arrow indicates downward flow. }\end{aligned}$

$\longleftarrow$ FLOW INTO BOREHOLE - Arrow pointing away from caliper log indicates flow into borehole.

FLOW OUT OF BOREHOLE - Arrow pointing towards caliper log indicates flow out of borehole.

Figure 2-10. Heatpulse-flowmeter measurements for well BK-3046, Fischer and Porter Superfund Site, Warminster Township, Bucks County, Pennsylvania, July 17, 2008. 


\section{Appendix 3. Summary of Aquifer-Isolation Tests}

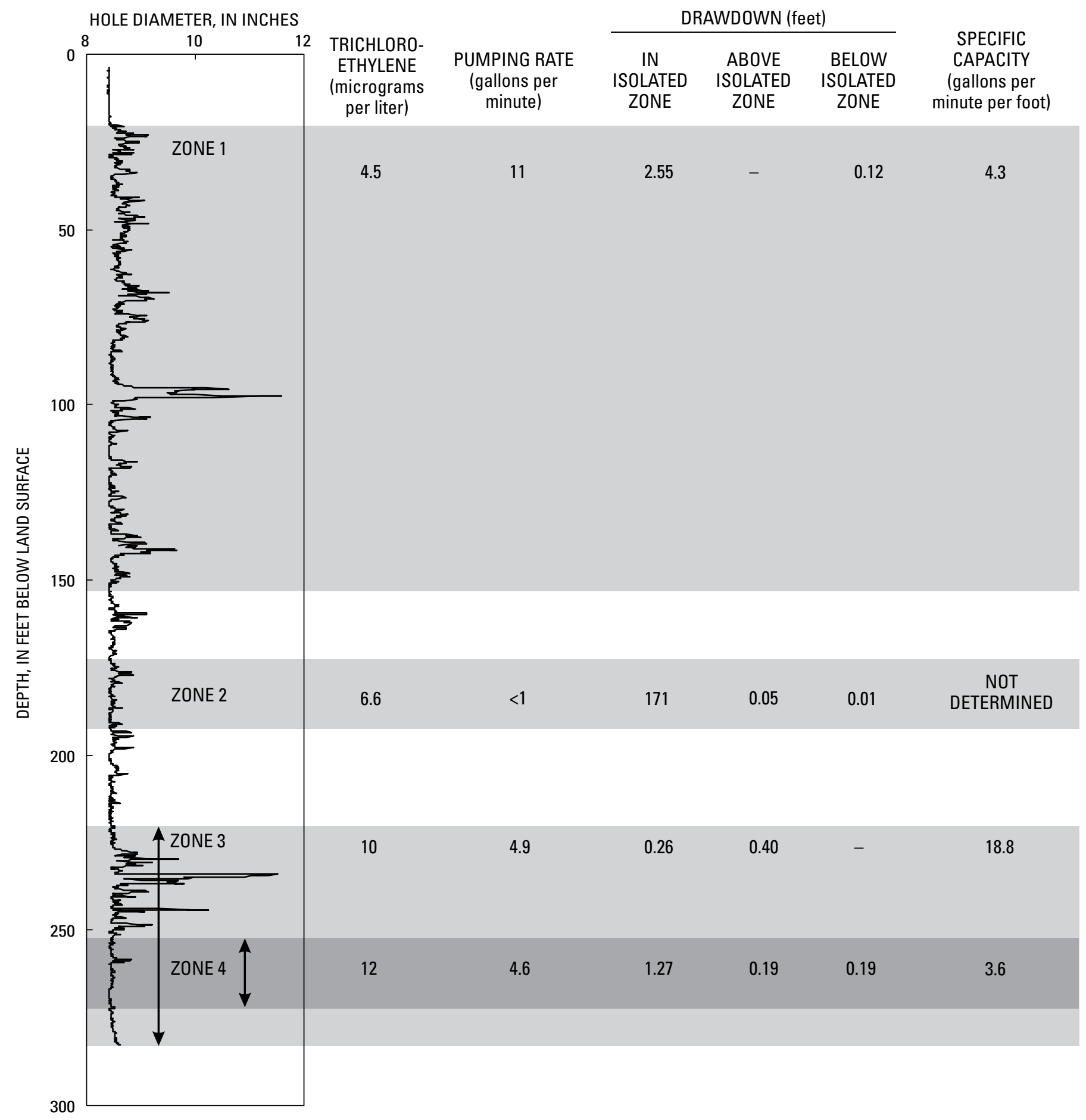

Figure 3-1. Aquifer-isolation test results for well BK-3042, Fischer and Porter Superfund Site, Warminster Township, Bucks County, Pennsylvania, July 29-30, 2008.

$[<$, less than; -, no data, only one packer inflated] 


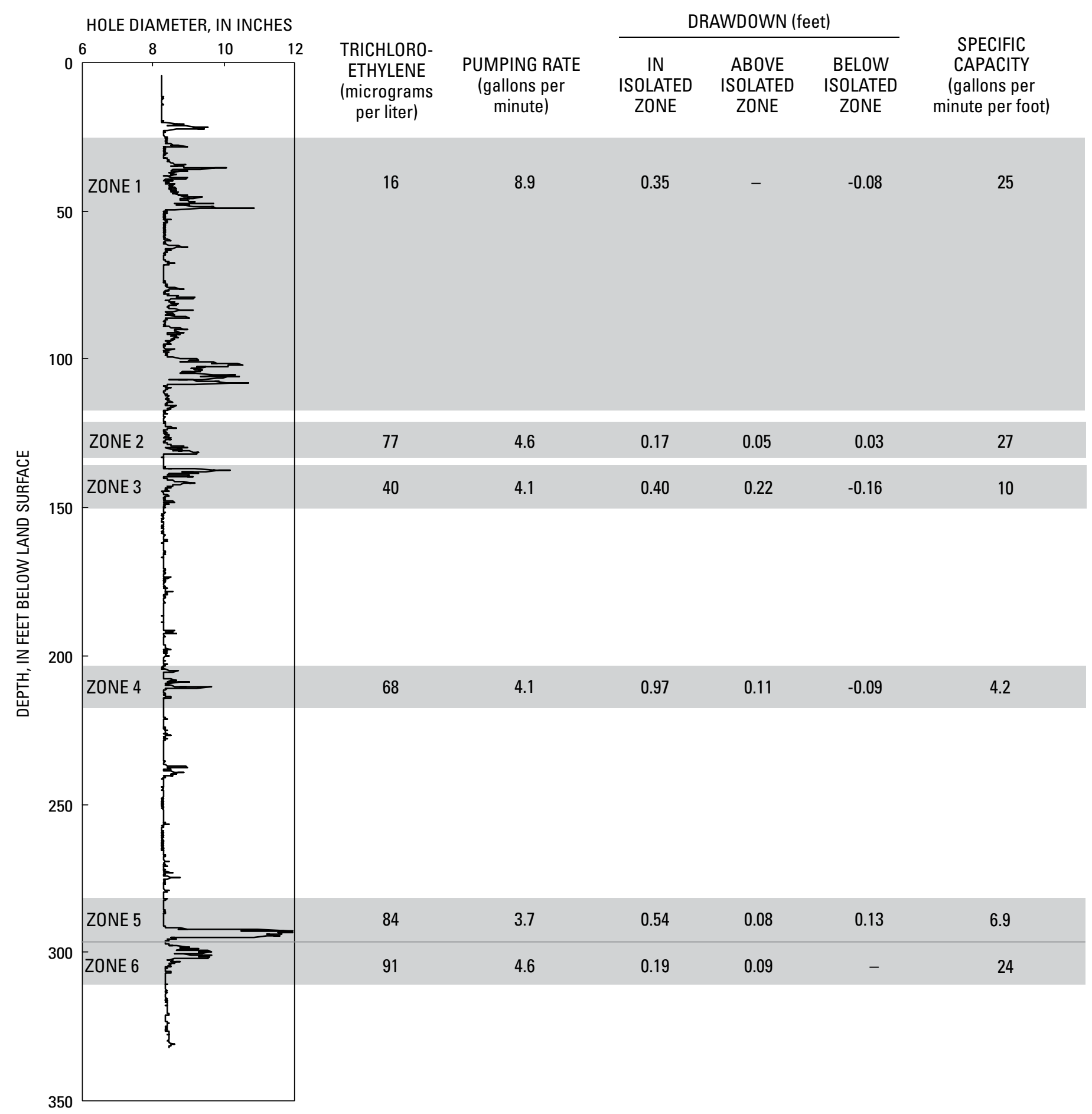

Figure 3-2. Aquifer-isolation test results for well BK-3043, Fischer and Porter Superfund Site, Warminster Township, Bucks County, Pennsylvania, July 22-24, 2008. A negative drawdown indicates a rise in water level during the test. $[-$, no data, only one packer inflated] 


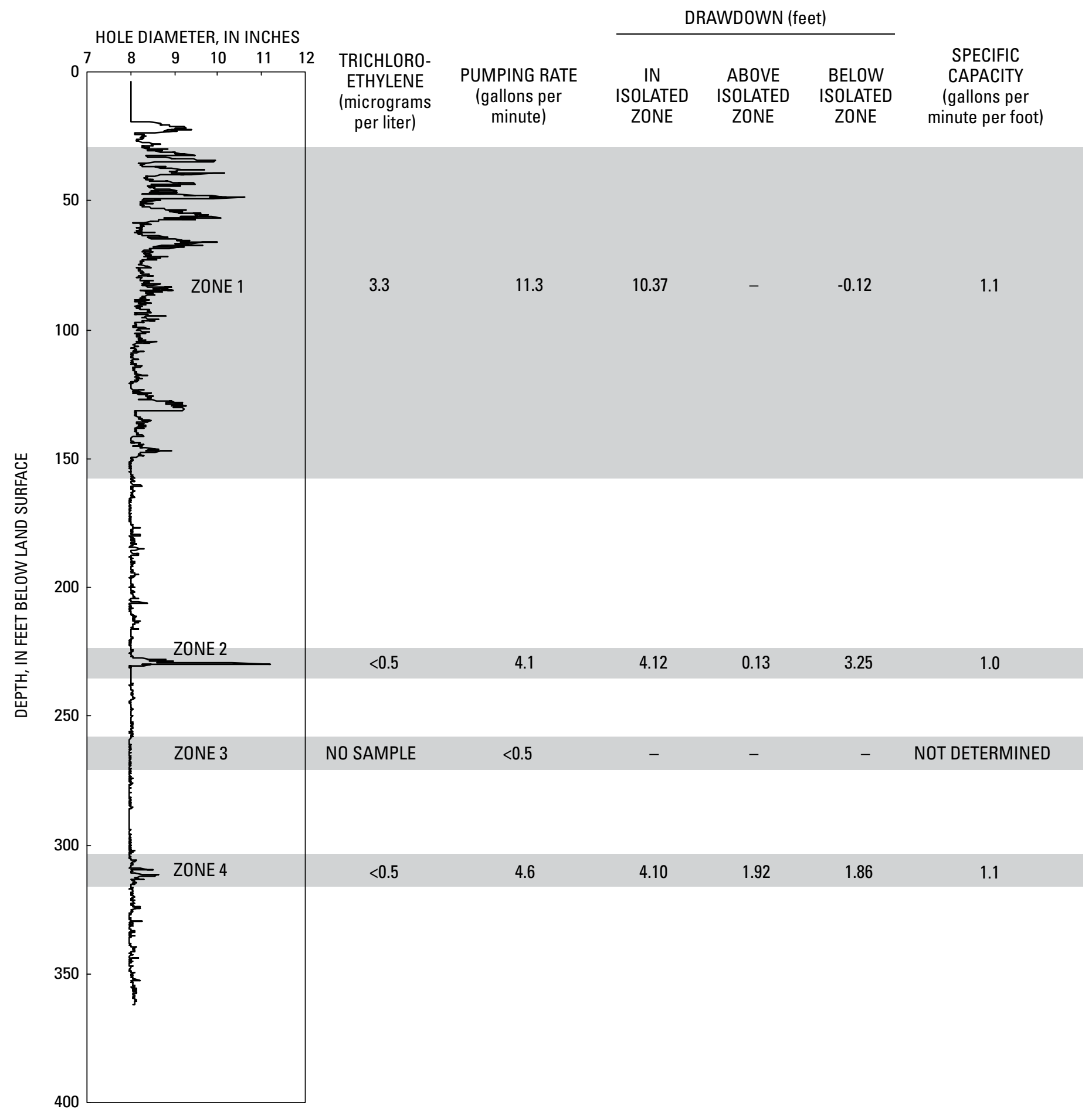

Figure 3-3. Aquifer-isolation test results for well BK-3044, Fischer and Porter Superfund Site, Warminster Township, Bucks County, Pennsylvania, July 25-28, 2008. A negative drawdown indicates a rise in water level during the test.

$[<$, less than; -, no data] 


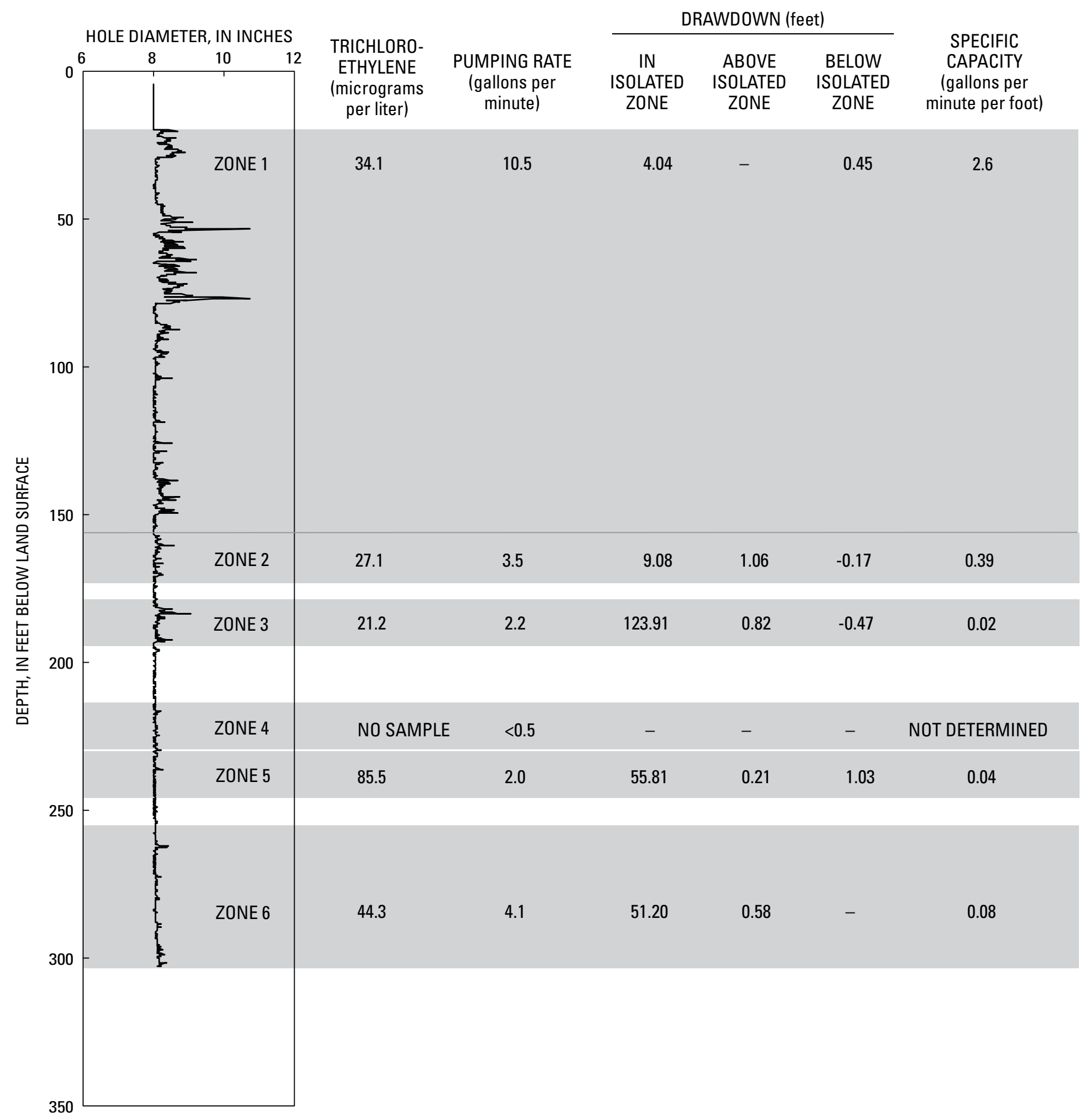

Figure 3-4. Aquifer-isolation test results for well BK-3045, Fischer and Porter Superfund Site, Warminster Township, Bucks County, Pennsylvania, August 13-15, 2008. A negative drawdown indicates a rise in water level during the test. $[<$, less than; -, no data] 


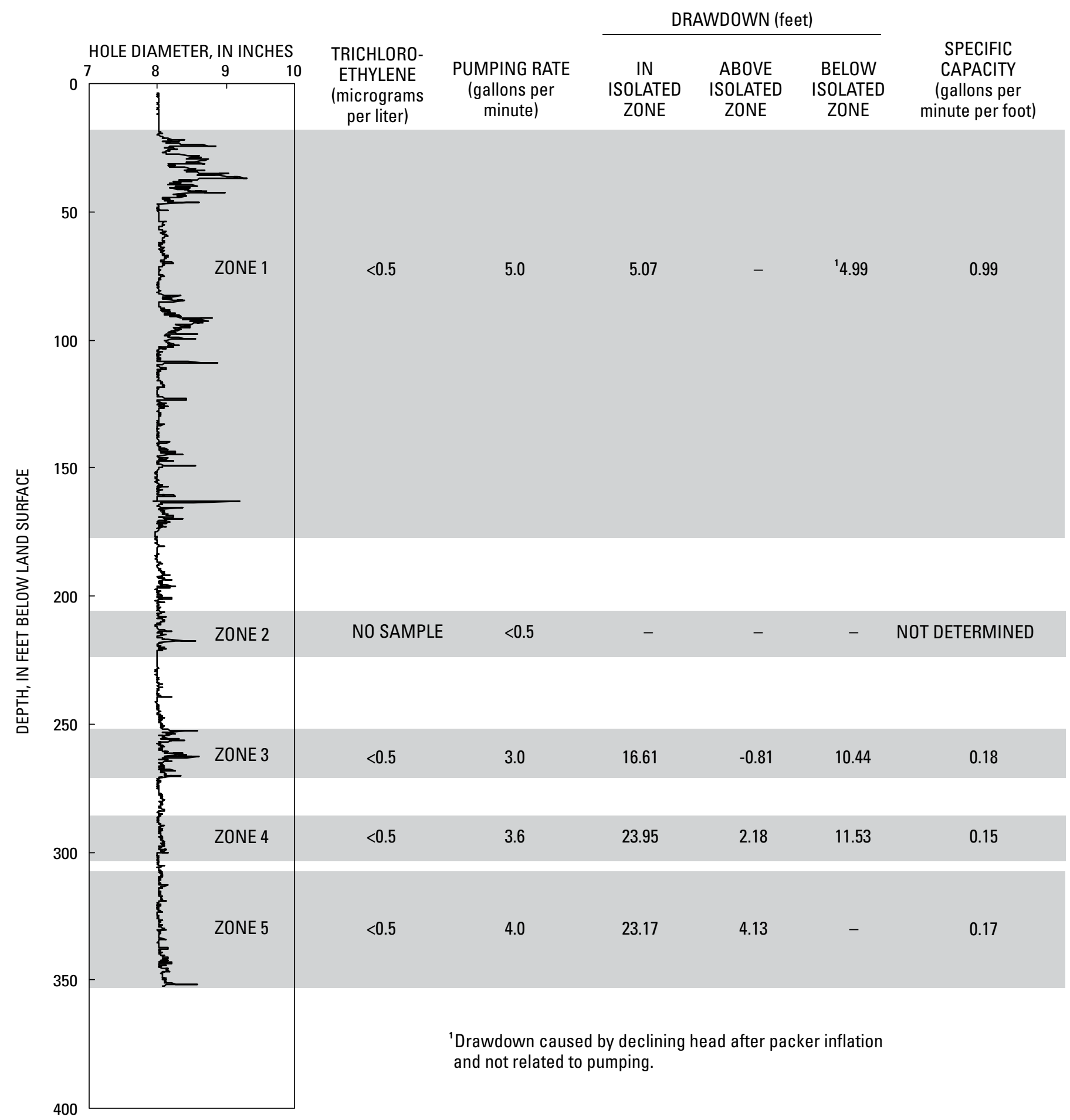

Figure 3-5. Aquifer-isolation test results for well BK-3046, Fischer and Porter Superfund Site, Warminster Township, Bucks County, Pennsylvania, July 31 and August 1, 2008. A negative drawdown indicates a rise in water level during the test. $[<$, less than; - , no data] 

Prepared by the West Trenton Publishing Service Center.

For more information concerning this report, contact:

Director

U.S. Geological Survey

Pennsylvania Water Science Center

215 Limekiln Road

New Cumberland, PA 17070

dc_pa@usgs.gov

or visit our Web site at:

http://pa.water.usgs.gov 


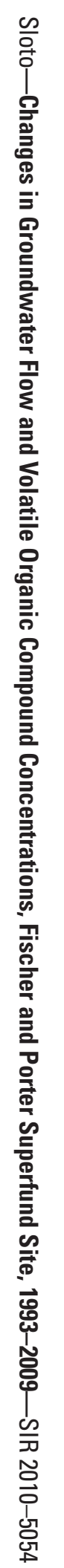

